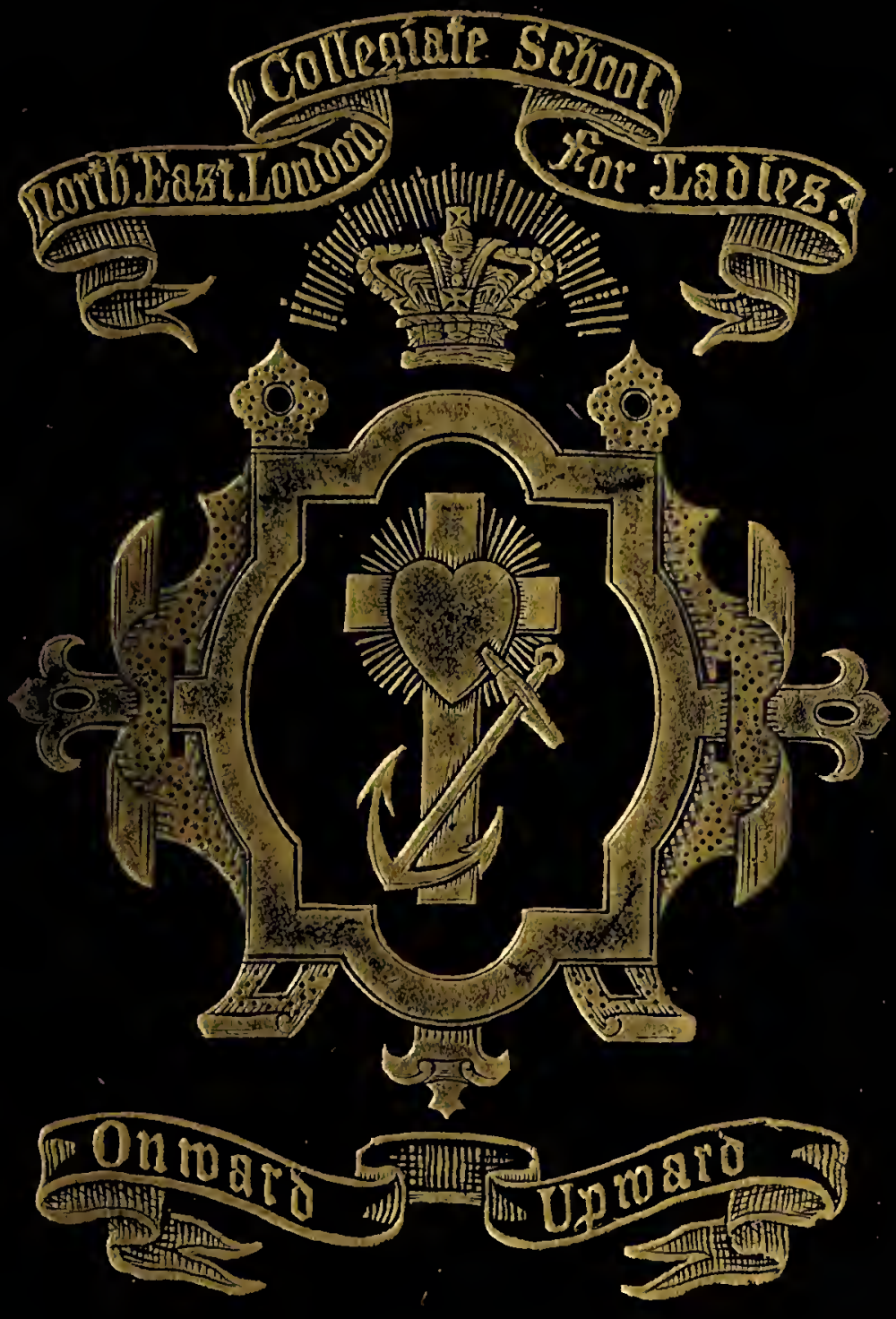




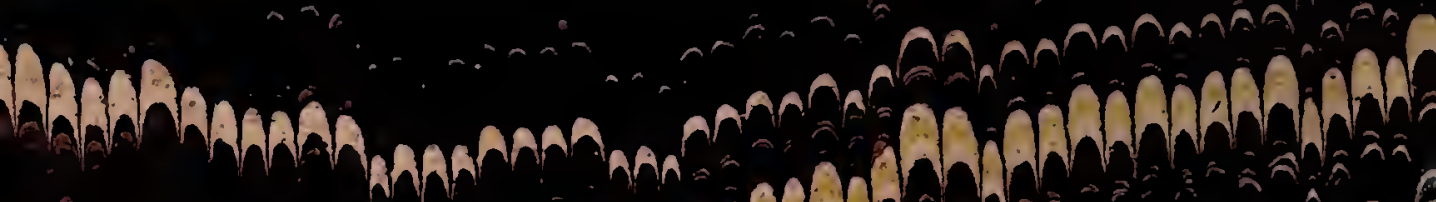

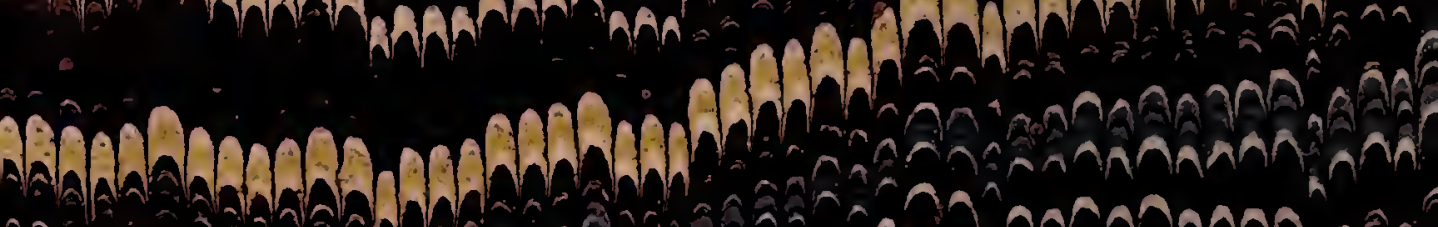

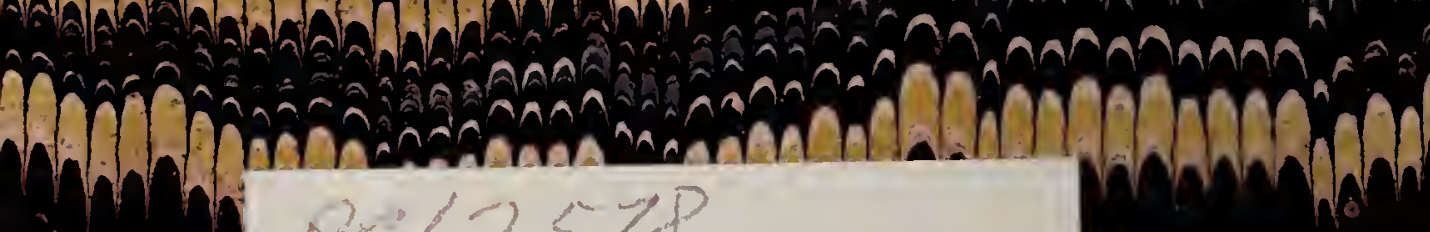
Prob 2578

manphan

Mamana

Minmand

Library

of the

University of Toronto whangent?

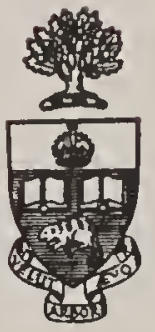

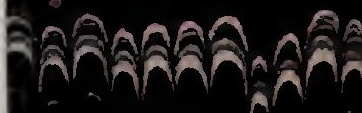

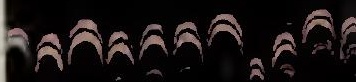
Dananan MAAMANAM

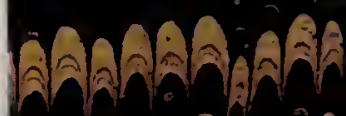

nin

$\operatorname{lin}$

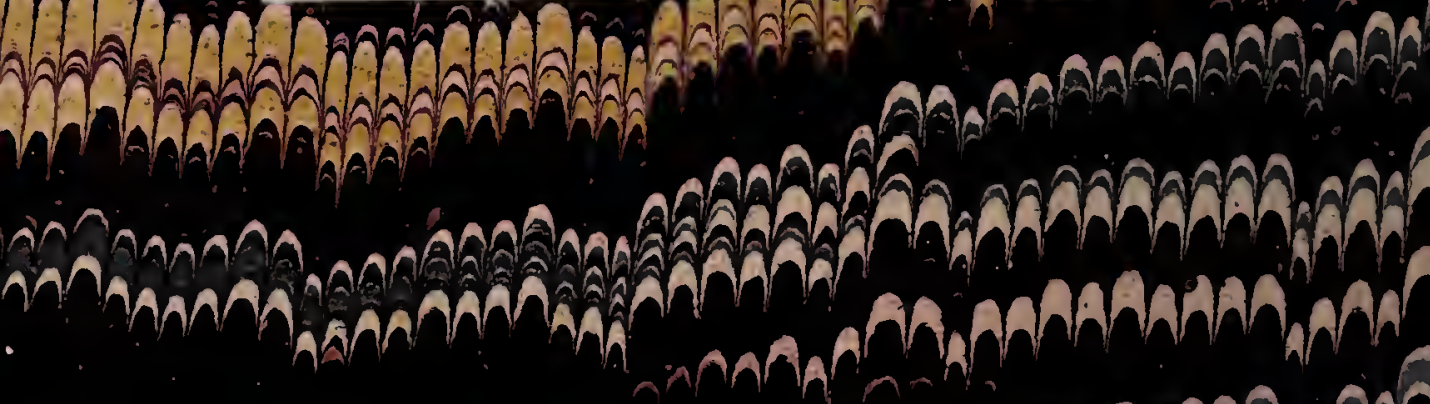

Alatarana

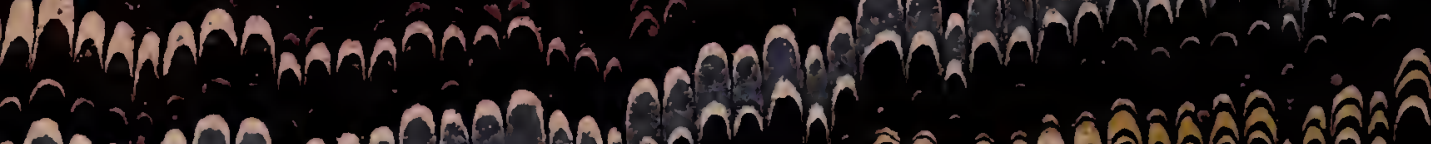
hamphranch

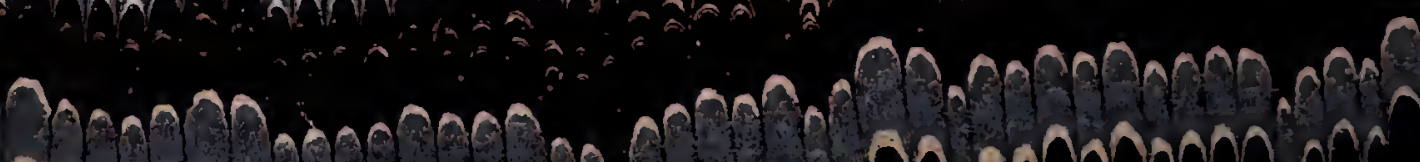




\section{Wh: $\quad A A_{A} A A A$}

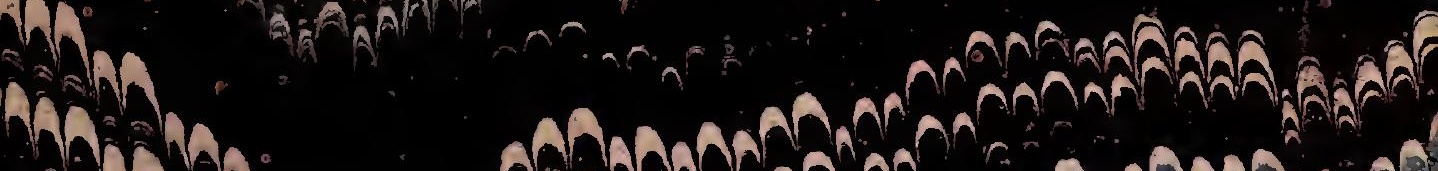

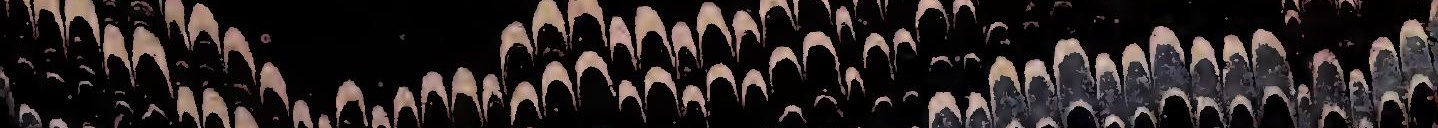

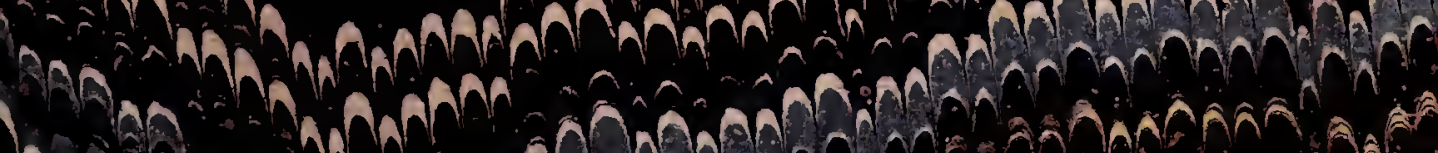

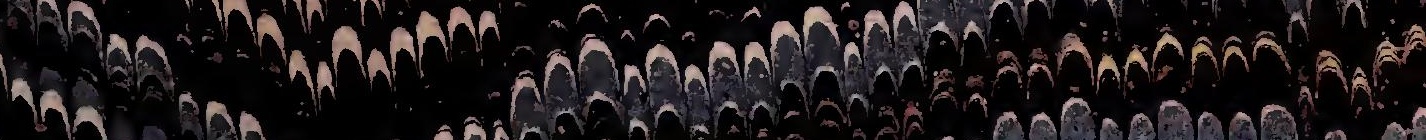

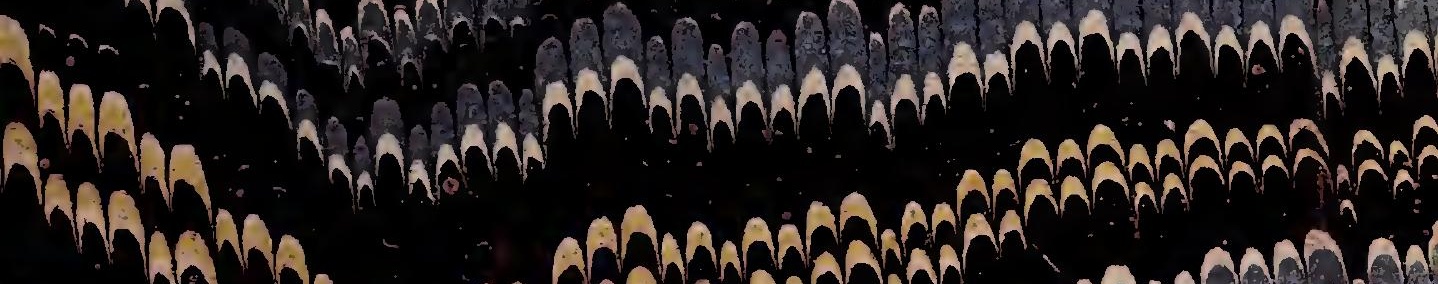

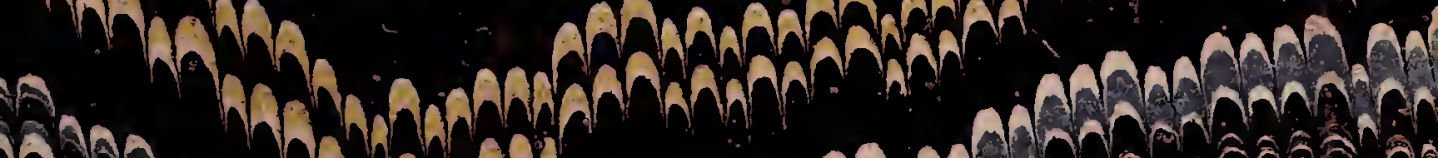

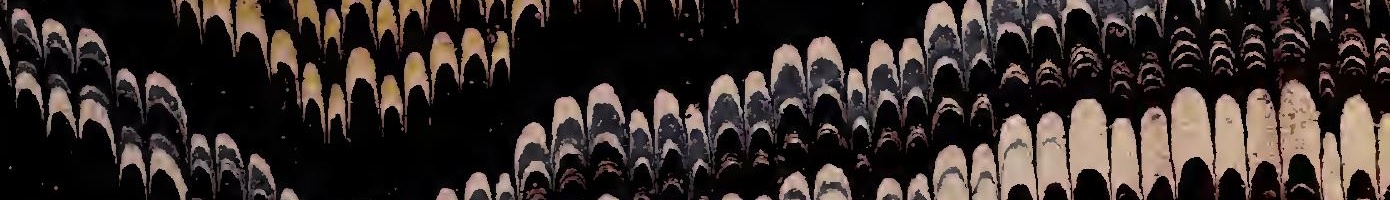

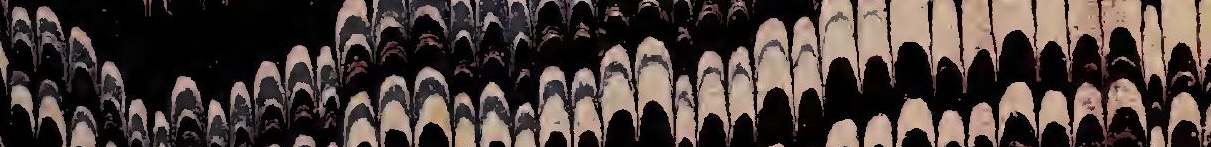
- An

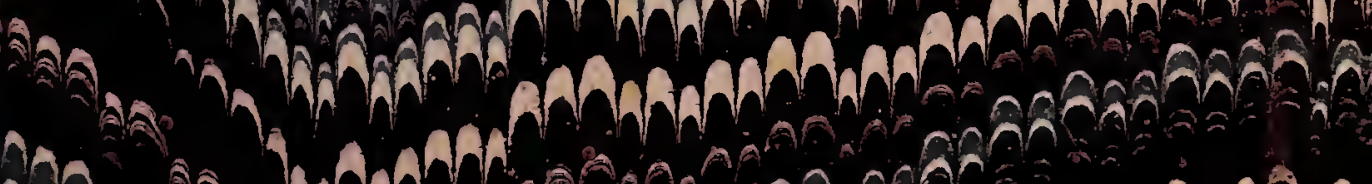

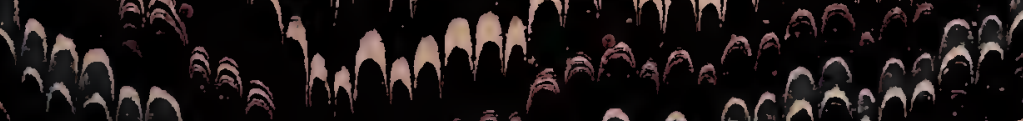
O O MAM

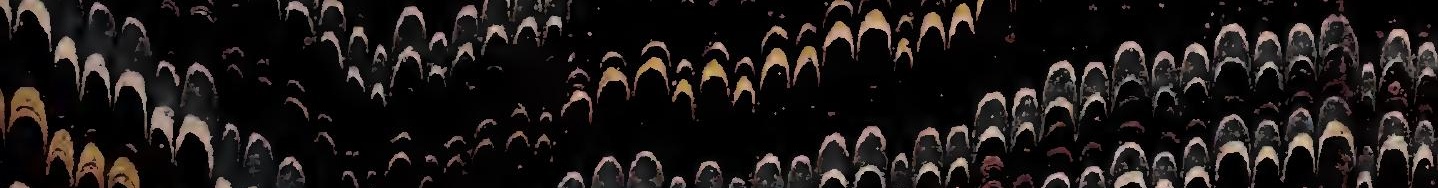
DOA ATh WA A A ANCA A.

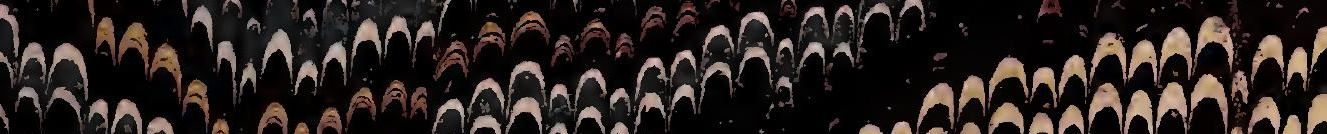
等

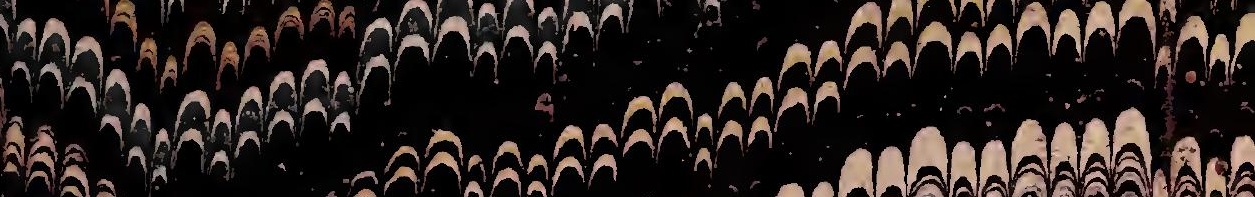
(4) U.

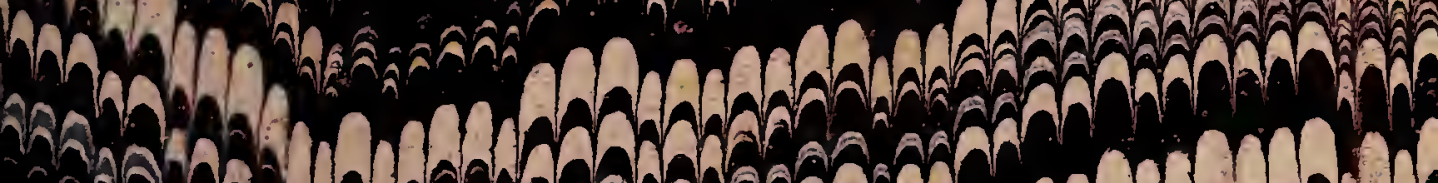
A A A

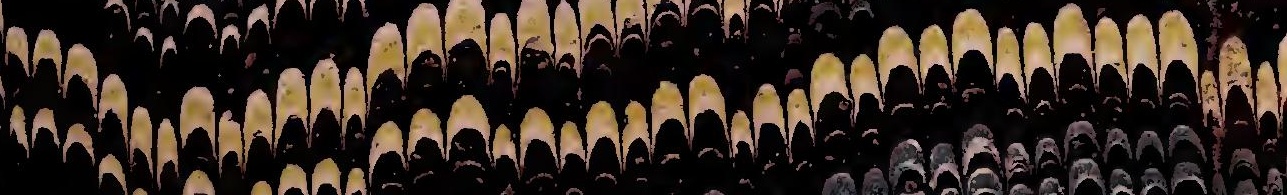


Polvares call

fingige Pondeng if 76

$$
(30)
$$






\section{I, ES SON S}

ELE MENTARY BO'A N Y. 


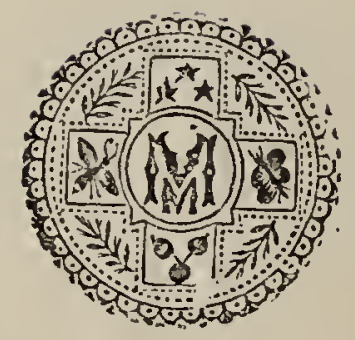




\section{LESSONS}

IN

\section{ELEMENTARY BOTANY.}

THE PART OF SYSTEMATIC BOTANY BASED UPON MATERIAL LEFT IN MANUSCRIPT

BY THE LATE PROFESSOR HENSLOW.

WITH NUMEROUS ILLETSTRATIONS.

BY

DANIEL OLIVER, F.R.S., F.L.S.

KEEPER OF THE HERBAKIUM AND LIBRARY OF THE ROYAL GARDENS, KEW, AND PROFESSOR OF BOTANY IN UNIVERSITY COLLEGE, LONDON.

NEW EDITION.

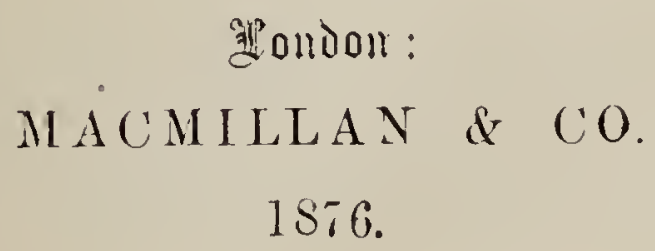

15.6.

[The Right of Translation and Repreduction is reserred.] 


\section{LONDON :}

12. CIAY, SONS, AND TAYLOR, PRINTERS, BREAD STREET HILI. 


\section{PREFACE TO FIRST EDITION.}

Ir was the intention of the late Professor Henslow to publish a small volume of Lessons on Botany, in illustration of the methods which he employed with such cminent success in his class at the University of Cambridge, and also in his parish school at Hitcham, in Suffolk.*

At the time of his lamented decease he harl collected a considerable amount of material for this work, but it was not left in a sufficiently forward state to send to the printer without ardition and modification.

In July of the present year, Professor Henslow's manuscripts intended for the work were placed in my hands by Dr. Hooker and the Rev. George, Ifenslow, with full permission to make what use I thought proper of his material in the prepara-

* The "Luisure Hour" for 1862 (page 670) contains an account of Professor Honslow's method of teaching Botany in Village Schools, by the Rev. George Henslow. See also l'rofessor Henslow's pamphlet, "Illustrations t" be employed in Practical Lessons on Botany, allapted to Beginners," published by Messrs. Chapman \& Hall, 1853. Priso 6d. 
tion of an inexpensive book, designed to teach the Elements of Botany on Professor Henslow's plan of selected Types, and by the use of "Schedules."

Feeling that there might be good service in a book of this kind, which, instead of interfering with the excellent text-books of Botany already published, might serve rather as introductory to them, and suffice, with constant reference to the plants themselves, to insure to the diligent learner a sound foundation for more advanced Botanical studies, I determined to prepare these "Lessons in Elementary Botany," basing the systematic portion (Part II.) upon the Type Lessons, which formed the largest and most valuable part of Professor Henslow's manuscripts.

As no sufficient introduction to Systematic Botany had been prepared by Professor Henslow, I have drawn up a few chapters, embracing the elements of Structural and Physiological Botany, treated in as simple a way as appeared to me consistent with practical usefulness. These elementary chapters it is desirable beginners should master before undertaking the methodical study of the Ordinal Types. In working up the latter, I have made the most free use of Professor Henslow's materials, frequently quoting entire passages from his manuscript. I have, however, omitted much which Professor Henslow had 
introduced, with a view to show the important "instructional value" of Botany as an "educational weapon," in the opportunity which Botanical Lessons afford the teacher of introducing to his class a large amount of useful information upon topics of the most varied kind. Thus I find a lesson in pneumatics apropos of pop-guns, made of the stem of the Elder ; an account of soapmaking, and the method of ascertaining specific gravities, in connexion with the Olive Order, represented in Britain by the Ash; how to analyse a Potato, under the Bittersweets; an account of wonderful bells, under the Bell: flowers; of glass-making, under the Saltworts, formerly burnt for the sake of their alkaline salts; of brewing, under Hops; and the like. I have omitted such matter because it would require more space than could be afforded in a book of small cost, to be used by private learners as well as by teachers; and also because the variety of topics which a teacher may thus introduce, and which his own intelligence may suggest, is infinite.

Professor Henslow's plan of employing "schedules," designed to direct the attention of the pupil at once to the most important points of structure, I have adopted in my own class with much advantage. Their use should be conmenced as soon as the first six chapters are 
จiii

thoroughly acquired. Any printer would strike off a few hundreds of blank "schedules" at a small cost, but the necessary form may be easily drawn with pen or pencil by the student himself. I strongly recommend their use, both by private students and in colleges and schools.

Most of the excellent woodcuts employed in this work were drawn by Professor Henslow's daughter, Mrs. Barnard, of Cheltenham, from the admirable Sheet Diagrams designed by Professor Henslow, and executed by Mr. Fitch, for the Committee of Council on Education. They have becn liberally placed st the disposal of the publishers by the Rev. George Henslow.

I.). 0.

KEW. Sertsmber 1823. 


\title{
LESSONS IN BOTANY.
}

\author{
PART I.
}

\section{H A P E R I.}

\section{Á BUTTERCUP IS EXAMINED.}

1. The Root.-Its form and general structure : it peno. trates the soil ; is colourless ; irregularly branched; destitute of leaves; and its extremities are sheathed.

2. The Stem.--It ascends; is coloured; bears leaves and branches at definite pinints; the extremities are not sheathed, but give off, successively, rudiments of leaves.

3. Foliage-leaves. - They are borne by the stem only. "Radical" and "cauline" leaves : thin, coloured green, consisting of an horizontally expanded blade with, or without, a petiole.

4. Flowers consist of leaves. The peduncle. Suppres. sion of internodes in flowers. The receptacle of the flowcr.

5. The sepals; forming the calyx.

6. The petals ; forming the corolla.

7. The stamens; bearing anthers which contain pollen. grains. The stamens are hypogynous.

8. The carpels; each containing an ovule. The stigma.

The style. The carpcls, collectively, constitute an apocarpous pistil.

9. The carpels persist after the other parts of the flower fall away. The fruit; secd; embryo and albumen. 10. A summary of the parts examined.

ATHER, first of all, a specimen of the
Common Buttercup. 'There are at least three different plants included under this name, aimost equally common in 
mearlows and pastures over all England, and most of Scotland, but as they nearly resemble each other it does not signify which is taken. In gathering the specimen take it up carefully, so that the root may be uninjured.

Proceed now to examine your buttercup.

1. Observe the Root, noting in what respects it differs from the parts which grow above ground. It consists of numerous fibres, about the thickness of small whip-cord, tapering at their extremities and giving off irregularly many thread-like fibrils. It is destitute of the green colouring of the stem and foliage, being pale or nearly white: it bears neither buds nor leaves, and

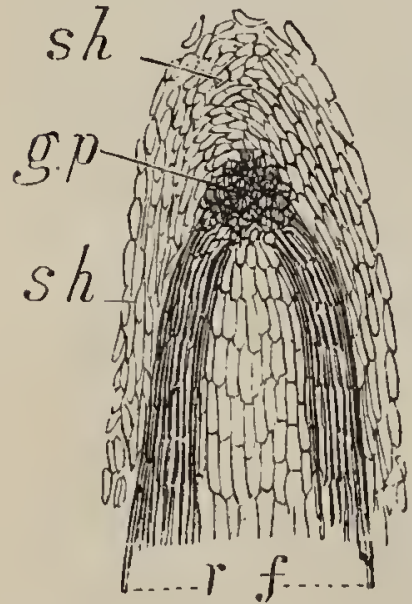

y'rG. 1. Longritudinal section througl the extremity of a root-fibre of Buttercup, marsnified. - gp. growing point. sh. sheath. $r f$. root.fibre. its branches, from their direction, appear to have avoided the light.

If you can find the tip of one of the root-fibres uninjured, cut it off, and examine it minutely with your magnifying glass. In case you have not the nleans of examining it with a higher magnifier, you will find figure 1 a sufficiently correct representation of it, divided through the middle and magnified many times. The point which I want you particularly to note is this. The extremity of the fibre is covered by a closely fitting sheath, protect ing the actual growing point, which is hidden immerliately within the end of the sheath, to which it is directly joinerl. This protecting 
sheath is being constantly renewed, at its inner side, by the "growing point," so that as the outer layers become worn or withered, by forcing a way through the soil and pebbles, they are constantly replaced by inner layers which take their turn, replace them, and then die; to be in like manner replaced by fresh inner layers derived from the "growing point," so long as the root continues to live.

Yon find, then, that the ront avoids the light; that it is pale or nearly white; that its fibres give off, irregularly, numerous delicate threadlike branches (fibrils); that it is destitute of buds and leaves, and tirat the tips of the root are protected by cellular sheaths.

2. Now examine the STEM.

You observe, at once, that the stem rises directly from the ground, seeking, rather than avoiding, the light. ... In"one kind of buttercup, growing in moist soils, there are two sorts of stem on the same plant; one a creeping stem, which has the power of giving off roots freely at its joints, and which, spreading along the ground, multiplies the plant by forming offsets, and the other an erect stem bearing flowers. It is the flower-bearing stem we are speaking of just now.

Excepting the lowest thickened portion more or less buried in the soil, the stem is coloured green, and not being woody we may speak of it as hurbaceous. It bears several foliage-leaves arranged on different sides of the stem. The lower ones spring in a tuft from its base, and have long stalks. The upper foliage-leaves aro without stalks, and arranged singly ou the stem, 
although sometimes they are so deeply divided as to look as though they were in threes.

If we examine the growing point of a young stem under a magnifying glass, carefully dissecting away the leaves which surround it, we shall find that to the very apex it continues to give off", successively, minute lateral prominences, which are the rudiments of leaves. Both foliage and flower-leaves originate upon the stem in the same way, but they soon become different, both in their arrangement, form, texture, and colour. The stem never terminates in a cellular sheath like that which protects the tips of the root.

The branches spring from points where foliageleaves are given off from the stem; each branch occupying the angle (called the axil of the leaf) which the leaf makes witll the stem.

At the extremity of the principal stem of your fully-grown buttercup, you find a tuft of coloured leaves forming a flower. All the branches, also, end in flowers or flower-buds.

The stem, we find, ascends; is coloured green, and is herbaceous in texture; it bears foliageleaves and ends in a flower.

3. Foliage-leaves. - I use the term foliageleaves at present simply in order to avoid confusion with the leaves of which flowers are composed. It is not necessary you should always call them so, but it is necessary that you thoroughly understand that, speaking generally, whatever is borne by the stem and its branches is a leaf of some kind, whether it be green, as are foliageleaves, or coloured, as are flower-leaves.

We have already remarked that the lowest leaves have long stalks. As they seem to spring 
from the root they may be called radical leaves. They really spring from a portion of the stem, which is thickened and more or less buried underground, giving off root-fibres below and radicalleaves from above. This portion of the stem is called the stock.

The point on the stem from which any leaf is given off is called a node; the space between two nodes is called an internode. It is owing to the non-development of the internodes of the stock that the leaves which it bears appear to bo given off in a tuft.

Each radical leaf consists of stalk and blade: the stalk supporting the blade is called a petiole. 'i'he base of the petiole, observe, is more or less sheathing, and the blade is much divided into deep segments, which again are further more or less lobed. The upper leaves, obviously springing from the stem, may be described as cauline. Being destitute of petioles, they are termed sessile. The same word is used of any part of a plant to denote the absence of a stalk, whether that stalk be a petiole (which is the stalk of a foliage-leaf only) or not. All the foliage-leaves have the blade spread out more or less horizontally, and they are all coloured a deep green. They may be hairy, or nearly glabrous, that is, destitute of hairs.

We find, then, the foliage-leaves to be borne by, and around, the stem ; they are thin, colourer green, and consist of petiole and blade, or of blade only; the blade being spread out horizontally. We now come to the examination of the

4. Flowers, and as the leaves of which theso consist ure smaller than the foliage-leaves, and some of them, in the buttercup, very small indoed. 
it will be necessary that you be very careful in your observations, making sure that you thoroughly understand every stage of your progress.

The upper part of the stem serves as a stalk to the flower. Flower-stalks are distinguished as peduncles. The peduncle of the buttercup may be either round or furrowed, according to the kind which you have gathered. Before proceeding to dissect (to separate carefully into its pieces) a flower, select one that has but just opened, and which has lost none of the parts which it possessed while still a bud; that is, before it expanded.

Observe, first, that all the coloured leaves which form the flower are apparently arranged

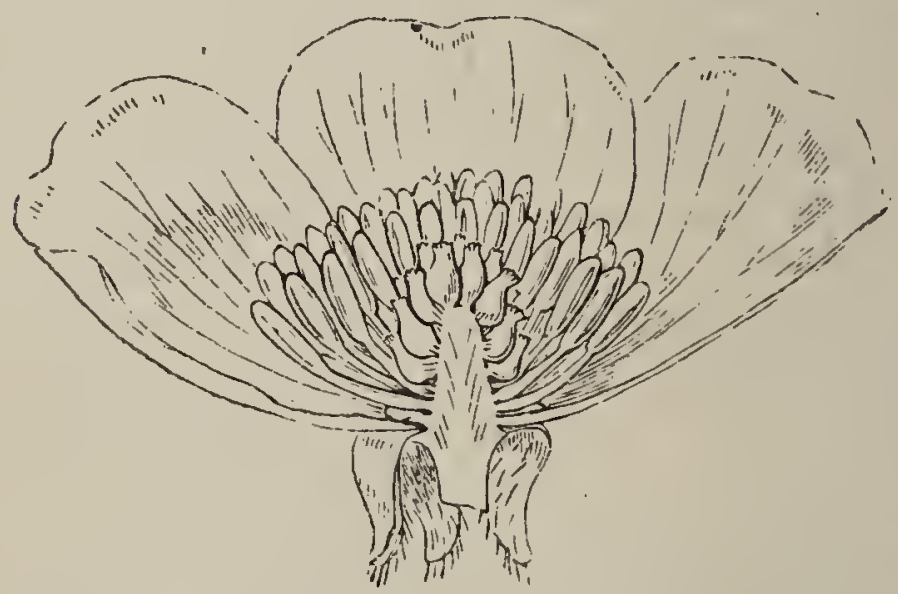

Tis. 2. Vertical scction of flower of Buttercup, showing the parti of the flower inserted upon a conical reccptacle.

upon the very summit of the stem. The inter. nodes of the stem which separate the upper foliage-leaves cease, or are suppressed, in the flower, so that all the parts are in close juxtaposition. This is characteristic of flowers. The top of the flower-bearing stem, from which the 
Hower-leaves collectively spring, is called the receptacle, or floral receptacle.

5. Proceed next to note that there are, in the flower, five separate outer leaves arranged in a whorl; small, coloured yellow, and either spreading or sharply curved back, according to the kind of buttercup you are examining. These leaves are each entire - that is, without the lobes or divisions of the foliage-leaves. They fall off early, and hence may be described as deciduous. These five outer leaves of the Hower are singly termed calyx-leaves or Sepals; together they form the Calyx of the fluwer. The sepals being free, that is, separate from each other, and from the other parts of the flower, the calyx is poly-sepalous. *

6. Immediately inside the calyx are five, rather larger, separate, nearly sessile, brightly coloured leaves. These also are arranged in a whorl, and they are singly placed opposite to the intervals between the sepals; not opposite to the sepals themselves. Like the sepals they are de. ciduous. Singly, they are the corolla-leaves or Petals; the five together form the Corolla of the flower. The petals being free the corolla is polypetalous; being equal in size and form, it is also regular.

7. In the examination of the rest of the flower much nicety is required. Having stripped off the sepals and petals singly, and laid them aside, proceed to the third series of flower-leaves.

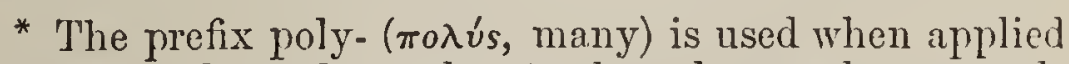
to sepals and petals, to denote that the sepals or petals no free rather than that they are actually many ir unmber. Usually there are not more than three, four, ur five sepals or petals in a flower. 
These are very different in form and structure from both sepals and petals, though, like them, they are all free; that is, distinct from, and independent of, each other. They

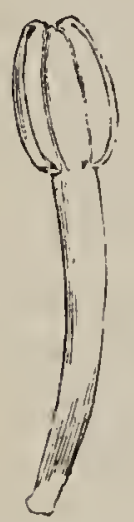

Fig.3. Stamen of Buttercup. each consist of a lower stalk-like portion, bearing an upper somewhat thickened, oblong, and grooved head. This stalk is termed the filament; the oblong head which it supports, the anther; and these together constitute a staminal leaf or Stamen. The stamens of the buttercup are shorter than the petals. As they are numerous, and, as we have just observed, free, they are said to bo polyandrous.

The anthers we must examine more closely. We have already observed that there is a groove up the back (outer side), and another, less distinct, along the face (inner side). These grooves divide the anther into two lobes, right and left. If the anther be ripe, each of these lobes will split open

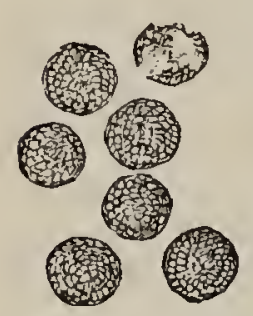

Fig. 4. Pollengrains of Buttercup (magnilied). near the outer edge, allowing certain fine powdery granules which it contains to be easily removed by insects or otherwise. These granules are essential to the flower as well as to the stamen, so we must carefully ex. amine them under a microscope. Fig 4 shows them highly magnified.

We find that they are distinct glo. bular cells with minutely granular contents. The fine powder is the pollen, and each globular cell is a pollen-grain.

Remove all the stamens, noting the minute; 
closely-packed, and spirally arranged scars which remain after you have picked them off. You fincl the stamens, like the sepals and petals, inserter directly upon the floral-receptacle. When this is the case they are technically described as hypogynous.

8. You have now left a small head, consisting of numerous distinct, but very closely-packed, sessile leaves, extremely unlike either sepals, petals, or stamens. Separate one of them, and try to cut it through lengthwise. Fig. 5 shows one thus treated. It is hollow, containing a single, pale-coloured body, attached to the base of the cavity. This is the rudiment of a future seed, and it is termed, in its present stage, an ovule. The hollow leaf which contains and protects the tender ovule is called a carpellary leaf or

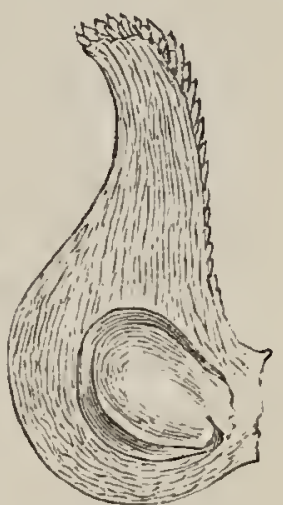

Fia. 5. Vertical section of a carpel of Buttereup, containing one inverted ovule.

\section{Carpel.}

Examine the outside of any one of these carpels with a magnifier, and you must observe that the upper portion is somewhat pointed, ending in a loose, cellular tip. This cellular surface is termed the stigma. It is invariably present. The lowe: portion of the carpel, containing the ovule, is the ovary. The stigma is very shortly stalked in the buttercup. In many plants the stalk of the stigma is of considerable length, sometimes several inches; whether long or short, however, it is called a style. If there be no style, the stigma is sessile. 
The structure of all the carpels of the buttersup is identical : they each contain one ovule, and are each provided with a stigma, and a very short style.

The carpels, taken together, constitute the pistil; they are the fourth and last series of the flower-leaves, and occupy the centre of the flower and, consequently, the extremity of the stem. As the parts of the pistil in the buttercup are wholly. free from the calyx, the pistil is termed superior, and as the carpels which compose it are free from each other the pistil is also apocarpous.

9. Gather now another specimen of the buttercup : one in a more advanced state, with the sepals, petals, and stamens of some of its flowers all

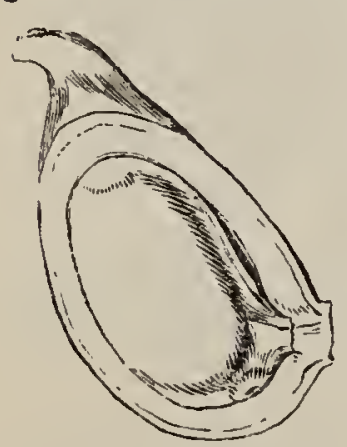

Fig. 6. Longitudinal section of a fruitcarpel (achene) of Buttercup,containilıgr one seed. fallen away, and only the heads of carpels (pistils) remaining. The pistil here is passing into iruit. The carpels remain dis. tinct from each other as at first, but they have enlarged and hard. ened; the stigmatic apex has dried up, so that the top of each carpel is simply pointed or slightly hooked. Opening any ripe carpel, a single seed will bo found filling its cavity. If we cut one of these seeds right through lengthwise, we shall find that it consists of a very thin (membranous) shell, the testa, enclosing a solid, uniform and horny substance, called the albumen; near the base of which, very careful observation will detect a minute body, the embryo or germ of a future plant. Fig. 7 shows such a section of the seed and the position 
of the embryo in the albumen. Suw, if you liks, a few of the fruit-carpels ; the carpel will decay away, and the seed, uuder favourable circumstances, will germinate and grow up into a buttercup plant.

10. You ought now to have a good idea of a buttercup, so far as its general structure is concerned. But before we proceed to future chapters, in which we shall inquire into the relation of the various parts of the plant to each other, into the office or function

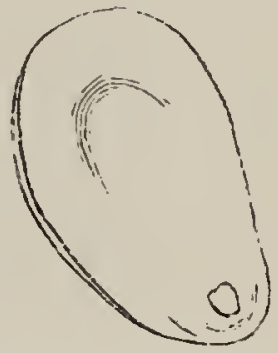

Fra. 7. Longitudinal section of a seed of Buttercup, show. ing the minute eimbryo at the base of the albumen. which each is intended to perform, and the relation which the organs of other plants bear to those of our buttercup, let us recapitulate the lifferent parts which we have observed thus far. If there be any part which has not been clearly made out, make a point of understanding it before proceeding further.

We have, first, a Root, which descends into the soil, gives off fibrils irregularly, and is palecoloured; the fibres have their extremities sheathed, and, as they do not give off the rudiments of leaves, the root is leafless. It is at first directly continuous with, and appears to pass into, the stem, but, in plants which are fully urown, the original root is supplemented by other root-fibres which are given off from the lower part of the stem.

The Srem ascends, bears foliage-leaves, from the axils of the upper of which spring branches; it is coloured green more or less, and terminates in the head of coloured leaves forming the flower. 
Root and stem, therefore, we find opposed to each other in the directions which they respectively take, as well as in several points of structure. . Together they may be regarded as constituting the axis of the plant; the root being the descending, the stem the ascending portion of the axis. Upon the ascending axis all the leaves, both foliage and flower-leaves, are arranged.

Leaves. - These, we have found, are of five different kinds. First are the radical and cauline

(1.) Foliage-leaves, called simply Leaves. * Then come the flowers, terminating the stem and its branches, consisting of-

(2.) Calyx-leaves, called sepals.

(3.) Corolla-leaves, called petals.

(4.) Staminal-leaves, called stamens.

(5.) Carpellary-leaves, called carPELs.

* In many plants we may distinguish two modifica. tions of the leaf below the flower-leaves, besides the green folinge-leaves, but as it is not important to dis. tinguish these in the buttereup we shall pass them by at present. 


\section{CHAPTER II.}

FXIMYATION OF A BUTTERCUP CONTINUTD.

1. The buttercup fades. Why? Experiment shows that it is because water is withheld.

2. The root an absorbing organ.

3. Water is exhaled from the leaves. Transpiration. Absorption.

4. Other substances, besides water, are absorbed. The ash and inorganic constituents of plants.

5. The organic compounds of carbon, oxygen, hydrogen: and nitrogen.

6. Ternary and quaternary.compounds of these elements are in contrast.

7. Source of carbon in carbonic acid.

8 Liberation of oxygen by plants under the influence of sun-light. Assimilation.

9. Source of nitrogen.

10. Processes of absorption, transpiration, assimilation, and respiration, performed by 'organs of nutrition,' viz. the root, stem, and leaves.

1. $\mathrm{Y}$ this time the specimen of buttercup has

13 probably faded; the leaves, now become soft and flaccid, are drooping, and the stem has lost much of its stiffness. How is this?

If the specimen be not quite withered, plant it again in the soil, and cover it with a flowerpot, or, better and more easily done, put the root in water, and place the whole in a cool shaded place for a few hours. We shall anticipate matters 
and suppose that this has been already done, and that you tried the experiment in this way upon three distinct specimens of buttercup. No. 1 you left lying upon the table. No. 2 was placeci with its root in water. No. 3 was hung upside down, with a flower or leaf in water, the roots in the air.

The general result of your experiment will be as follows:-After the lapse of, say, twenty-four hours or so, No. 1 will be, as we have already lound, faded; No. 2 will be nearly unaltered; No. 3 will be partially faded, the parts out of water especially. Hence we may gather that water supplied to the specimens prevents them from fading, especially if it be supplied to the root. On the other hand, if water be withheld, they farle.

2. If we take now the faded specimen first described and put its root in water, and leave it for a few hours in a cool, shaded room, we shall probably find, unless it be irretrievably withered, that it freshens more or less, the leaves and stem becoming tirmer and more nearly like their original state.

This experiment shows us, further, that water supplied to a fading buttercup enables it to recover.

Reflecting upon these experiments, we shall be led to the following conclusions:-

i. That water evaporates from the exposed surface of plants.

ii. That fresh supplies are taken into the plant by the root.

iii. That the stem serves to convey this watersupply from the root to the leaves. 
3. We may now try another simple experiment, devised by Professor Henslow, which shows that exposure to direct sunlight, rather than the dryness of the air, has to do with this evajoration of water from the leaves. Take six or eight of the largest, healthy, radical leaves of the buttercup you can find; two tumblers filled to within an inch of the top with water, two empty, dry tumblers, and two pieces of card, each large cnough to cover the mouth of a tumbler. In the middle of each card bore two or three small holes just wide enough to allow the petiole of a leaf to past shrough. Let the petioles hang sufficiently deep to dip into the water when the cards are put upous the tumblers containing it. Having arranged matters thus, turn the empty tumblers upside down, one over each card, so as to cover the blades of the leaves. Place one pair of tumblers in the sunshine, the other pair in a shady place. In tive or ten minutes examine the inverted tumblers. That exposed to the sun you will find already lined with dew on its cool side, while that kept out of the sun is still nearly or quite clear. It is manifest, therefore, that evaporation from the leaves must be not only rapid, but considerable in amount when plants are exposed to the sun whether in a dry or moist atmosphere.

This exhalation of vapour from the surface of plants is termed transpiration. A correct understanding, of the process explains how it is that plants growing in parlours are apt to become faded even when watered, because the taking up of water (termed absorption) by the roots cannot always keep pace with the transpiration from the leaves, owing to the rapid evaporation excited by 
dryness of the air. Since the specimen No. 3, experimented upon at the beginning of the present lesson, faded, notwithstanding the immersion of some of its leaves, it is clear that the root is the part which performs the office of absorption principally.

Every part of a plant or animal appropriated to a distinct purpose or function is termed an organ. Hence the root may be called the organ of absorption of the plant.

4. Now, not only is water absorbed by the root, but also various substances which are dissolved in the water. Hence we find, if we burn a plant carefully, that an ash remains, consisting of such of these substances as are not dissipated by heat, which were absorbed in this way, and which had been made use of by the plant, or stored away. in its tissues. Of the simple elements known to chemists, about twenty occur in the ash of plants; many of these, however, in very minute quantities, and never all in the same plant. Sulphur, phosphorus, potash or soda, lime, and silex, are those most generally found.

5. But if wo analyse an entire plant, and not the ash only, we shall find constantly present, besides the above, the elements carbon, oxygen, hydrogen, and nitrogen. And these elements are present, there is reason to believe, in every organized being, whether plant or animal, in combinations peculiar to organized beings. Hence, they may be called the organic elements, in coutradistinction to the (mineral) elements found in combinations which are not peculiar to organized veings, and soveral of which remain in the as 
Jf plants when burnt. The latter may be cailed the inorganic elements.

6 . These four organic elements do not exist separately in the plant, but, as we have said, in combination. Thus the carbon is united with oxygen and hydrogen (the last two the elements of water), forming the basis of a series of compounds, called ternary compounds, because they are composed of three elements. The nitrogen occurs combined with the same three elements, forming a quaternary compound, or compound of four elements. And these two series of organic compounds stand in remarkable contrast to each other in the plant, both in respect of the structures in which they respectively take part, and of function, as we shall point out when we come to speak of the minute structure of plants.

7. We have already explained how water (oxygen and hydrogen) finds access to the plant, as well as certain mineral substances which may be held in solution by the water. With regard to the important element carbon, experiments clearly show that it is absorbed in combination with oxygen, as carbonic acid gas, which occurs as a constant constituent of the atmosphere; and green leaves, under the influence of sunlight, possess the fower of absorbing it directly from the air.

8. But the most remarkable circumstance attending this absorption of carbonic acid is the liberation of oxygen gas by the leaves, very nearly to the amount absorbed in combination with the carbon of the carbonic acid gas. This liberation of oxygen is most easily shown by taking a few leaves which have been first soaked a day or two in water, so as to become saturated, and exposing 
them, plunged in water containing carbonic acid (as ordinary spring or pump water, in which it is always present), to direct sun-light. Minuto bubbles will be given off, under favourable circumstances, in a rapid and continuous stream. These bubbles consist of almost pure oxygen.

This fixation of the carbon and liberation of the oxygen of carbonic acid has been termed vegetable respiration; but as the conditions which obtain are the reverse of those characteristic of animal respiration, it may be more correctly spoken of as a part of the process of vegetable assimilation.

Repeated experiments have shown that some of the parts of the flower, seeds when germinating, and also plants or their organs which are not coloured green, absorb oxygen from the air, and give off carbonic acid gas. This may be resarded as a respiratory process. It is not improbable that the green parts of plants also miay, at least in the dark, absorb oxygen and give off carbonic acid in the same way, but in these parts the amount of carbon fixed greatly predominates over that which is liberated. The mutual relations, however, of these processes are as yet very imperfectly understood.

9. It is not yet perfectly clear from what source the plant obtains its nitrogen; not that the element is scarce, since it forms four-fifths of the atmosphere, but the precise state and combination (as in ammonia and nitrates) in which it cuters the plant, is still a matter of inquiry and discussion among scientific men. It is not absorbed, as free nitrogen, directly from the atmosphere.

10. The processes which we have briefly de. seribed of absorption, transpiration, assimilation, 
and respiration, we find, mainly concern the root, the stem, and the leaves. These are the foodproviders and preparers of the plant. Hence wo call them collectively the Nutritive organs; the root being, as we have shown, the organ specially of absorption, the foliage-leaves of transpiration, assimilation, and respiration. The stem, when green, assists the leaves in their work; but, speaking generally, it may be regarded merely as the support of the leaves, maintaining their connexion with the root.

In our next chapter we shall inquire into the nutual relations and functions of the leaves which compose the flower, deferring turther reference to the chemistry of the organs until we speak of their minute structure. 


\section{CHAPTER III.}

FUITHER EXAMINATION OF THE BUTTERCUP.

1. Function of the flower-leaves. Organs of reproduction.

2. Sepals and petals do not take part, directly, in the process of reproduction.

3. The function of the stamens. The pollen-grains are transferred to the stigma, and develop pollentubes.

4. The ovary of each carpel contains an ovule. The structure of the ovule. It contains a large cell to which a pollen-tube reaches. An embryo develops in this cell.

5. Deciduous and persistent organs of the flower.

6. Characters are derived from the reproductive organs, which form the principal practical basis of classification.

1. TE have already seen in the case of our buttercup, that the flower results in a head of fruit-carpels, each carpel containing a seed. The seed we found to contain the minute germ of a future buttercup, which we called the embryo. As it is the special function of all the leaves which compose the flower to contribute to this, formation of embryo-containing seeds, by means of which the huttercup is enabled to reproduce and multiply its kind, we may term all the parts of the flower organs of Reproduction, in contradistinction to the organs considered in our last chapter, which contribute primarily to the conservation of the individual buttercup, and which, from their functions, we styled, collectively, organs of Nutrition 
2. The four series of leaves of which the fluwer is composed do not each fulfil an equally important part in the production of the seed. The calyx, the corolla, and the stamens are deciduous. They fall away, leaving the carpels to mature into fruit. But they do not generally fall until after an important function has been accomplished by the stamens, either of the same flower, or of anuther flower of the same kind of buttercup. This function we shall briefly refer to here, deferring a fuller account of it to a later chapter, when we shall have to compare the stamens and carpels of the buttercup with the stamens and carpels of other plants.

'The two outer series of flower-leaves, the sepals and petals, may be regarded simply as organs designed to protect the smaller and delicate parts which they enclose during their early development; and perhaps, also, from their more showy colour and greater size, they may serve to attract insects which, we shall find, have an important work to perform, as aids in securing the formation of good seed. Hence the calyx and corolla are termed the envelopes of the flower. As both calyx and corolla are present in the buttercup, the envelope of the flower is double, or in two series. Hence the flower is termed dichlamydeous.

3. The anthers, we have observed, are divided lengthwise into two lobes, which lobes, after the expansion of the flower, become fissured near their margins, so as to liberate the grains of pollen which they contain. About the time that the anthers open to discharge their pollen, we may observe the stigma of each of the carpels to be rough with minute projecting cells, which, on 
sareful microscopic examination, we shall find to be slightly moistened. Upon the stigmas, after the flower has been open a few hours in fine weather, there may usually be found a few grains of pollen, which have either reached the stigma by direct contact of the anthers, or by means of some insect visiting the flower in search of nectar, and which, unwittingly, conveyed some of the pollen, accidentally adhering to its hairy limbs and body, to the stigma. This transfer of the pollen from the anthers to the stigma is highly important. If we separate a few stamens, with their anthers and pollen, and keep them apart from the rest of the flower; or if we remove all the carpels in a bud, so that stamens only remain within the envelopes, we shall find that they ultimately shrivel and wither up--pollengrains, and all-without undergoing further change. But the case is different with the grains of pollen which reach the stigma. After an interval (varying in different species from a few hours to several months) we find the pollengrains begin to grow-in this way :-

Each grain of pollen, as we have already learnt, is a single cell. These cells almost invariably have a double coat, an outer and an inner; and in the outer coat there are frequently thin places, or actual openings here and there, which permit the inner coat to grow through it at one or more points. This growth of. the inner coat of the pollen-grain is encouraged by the moisture which bathes the stigma, so that at length it protrudes, and, like an excessively minute root-fibre, penetrates the substance of the stigma, and passes down through the very slicrt 
style, until it reaches the cavity of the ovary. As the changes of which we speak can only be observed under a considerable magnifying power, we shall explain them more clearly by reference to the cuts, which represent some grains of pollen

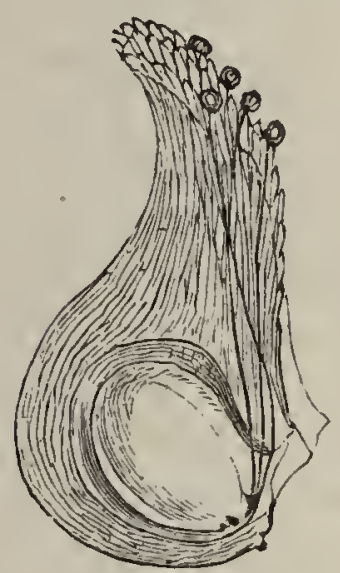

Eła. Sa. Diagram representing pollen-grains unon the stigma of a carpel of Buttercup, which have developed their tubes, reaching to the mieropyle of the ovule. The tubes are so delicate that it is almost impossible to traee them the whole way in the buttercup.

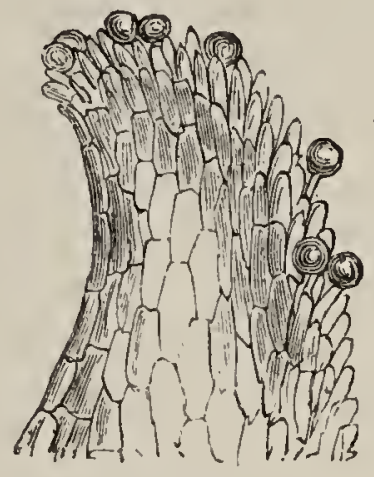

Fia. $8 b$. The stigma magnifled, with grains of pollen upon it.

which have developed tubes reaching into the svary.

4. The ovary contains a minute seed-bud, the ovule, which ovule in the buttercup is inverted (anatropous). The ovule consists of a central cone, called the nucleus of the ovule, around which central cone is a layer of cells forming the coat of the ovule. This cellular coat grows up around the nucleus, and closes over it, excepting at the top, where a very minute aperture through the coat is always left. This apcrture is called the micropyle. Owing to the ovule of the buttercup 
being inverted (a very frequent condition), the micropyle is found at the base of the ovule.

By the time that the pollen-tube has reached the cavity of the ovary, certain important changes have taken place in the cells which form the nucleus of the ovule. One cell has enlarged greatly, at the expense of its neighbours, so as to occupy a considerable part of the nucleus. This enlarged cell is called the embryo-sac, because within it we find the embryo to originate. But this is not until after the pollen-tube has reached the micropyle of the ovule, and actually penetrated to the upper end of the embryo-sac, against which it becomes closely applied. Presently, after this contact of pollen-tube and embryo-sac, a cell forms within the latter which ultimately develops into the embryo, and the ovule then beconies the young seed.

5. We now understand why the sepals, petals, and stamens can be spared so early. Their' function is soon accomplished, and their texture is too delicate to allow them to persist, although in some flowers the calyx or corolla, from a more succulent, or, on the other hand, from a dry membranous texture, may remain a considerable time atter flowering. Such a calyx or corolla is termed persistent.

(i. From what we have here described of tho functions of the different organs of the flower, the high importance to the plant of their proper performance must be plain. On this ground, therefore, and from the general constancy which the parts of flowers present in their principal features, both in the structure of the several pirts and in their relations to ench other, in groups 
of plants which from numerous general resemblances we may reasonably imagine to be related by descent (that is, related to each other in the same way that Europeans are more nearly related to each other than they are to the negro or Indian races, or as the different kinds of fish are more nearly related to each other than they are to birds or reptiles), botanists make use of characters afforded by the organs of the flower and fruit, to mark, in words, the principal divisions of the vegetable kingdom. Hence it is desirable, before we proceed to consider the organs which are more subject to variation, that wo should acquire a correct notion of the nature of the principal modifications to which the parts of the flower are liable in different plants.

With a view to this, and that you may be enabled at once to commence the examination and the describing of flowers, we shall proceed in our next chapter to compare with that of buttercup the flowers of a few common plants, representing the most important types, or kinds of modification, of floral structure. 


\section{CHAPTER IV.}

COMMON FLOWERS TO COMPARE WITI BUTEERCUP.

1. Cornmon plants are examined and compared with Buttercup in order to illustrate the more important modifications which they severally pre. sent, due, chiefly, to varying conditions of cohe. sion, adhesion, and suppression of parts.

2. Buttercup.

3. Wallflower.

4. Pea.

5. Bramble.

6. Apple or Pear.

7. Cow Parsnip or Carrot.

S. Daisy.

9. Deadnettle.

10. Primrose.

11. Stinging Nettle.

12. Willow.

13. Points of agreement in the structure of the plants just examined.

14. These characters are strengthened by other characters derived from the seeds and woud.

15. The structure of the seed. A Bean is selected. The parts of the seed and of the embryo.

16. Germination, and the way in which it takes place in the Bean.

17. Coniparison of the seeds of Bean and Buttercup). Albuminous and exalbuminous seeds.

18. They are both dicotyledonous.

19. No characters are absolute.

1. CATHER flowers of as many of the following common plants as you are able. The accompanying woodeuts must do duty for 
those which are not in flower, or which happen to be out of reach :

Wallflower, Pea, Bramble, Apple (or Pear), Cow Parsnip (or Carrot), Common Marigold, White or Purple Deadnettle, Primrose, Stinging Nettle, Willow, Arum or Cuckoo pint, Spotted Orchis, Daffodil, Tulip, Wheat.

There are three conditions which play a most important part in modifying the structure of flowers, to which we must direct attention before proceeding. These are cohcsion, adhesion, and suppression. The first two terms are used by botanists to denote the union of like (cohesion) or unlike (adhesion) parts of the flower. Thus union of sepals with sepals, of petals with petals, of stamen with stamen, of carpel with carpel, is said to be due to cohesion-parts of the same whorl or series being concerned. Union of corolla to stamens, or ovary to calyx, or of stamens to corolla or to pistil, is due to adhesion-parts of different whorls or series being concerned.

The term suppression is used to denote the absence of parts in a flower, which, from analogy, we might expect to find. Thus we shall find that in some fiowers the corolla is suppressed, in others the corolla and stamens, or the corolla and pistil. Sometimes but a single series of organs, either stamens or pistil, constitutes the flower, the three other series being suppressed. Single parts of a series, also, as a sepal, a petal, \&c., when absent are said to be suppressed.

2. In the ButTercup neither cohesion, adhesion, nor suppression of parts occurs: hence its flowers consist of four series of organs. We have a- 
Calyx .... inferio! and . polysepaious

$\left.\begin{array}{l}\text { Corolla } \\ \text { Stamens }\end{array}\right\} \cdot$. hypogynous. $\left\{\begin{array}{l}\text { polypetalous } \\ \text { polyandrous }\end{array}\right.$

Pistil ..... smperior ... apocarpous

In the examination of the flowers now before us wo shall find manifold variety in respect to these conditions of cohesion, adhesion, and suppression.

3. WALLFLOWER. - There are four free sepals, four free equal petals, and six free stamens, of

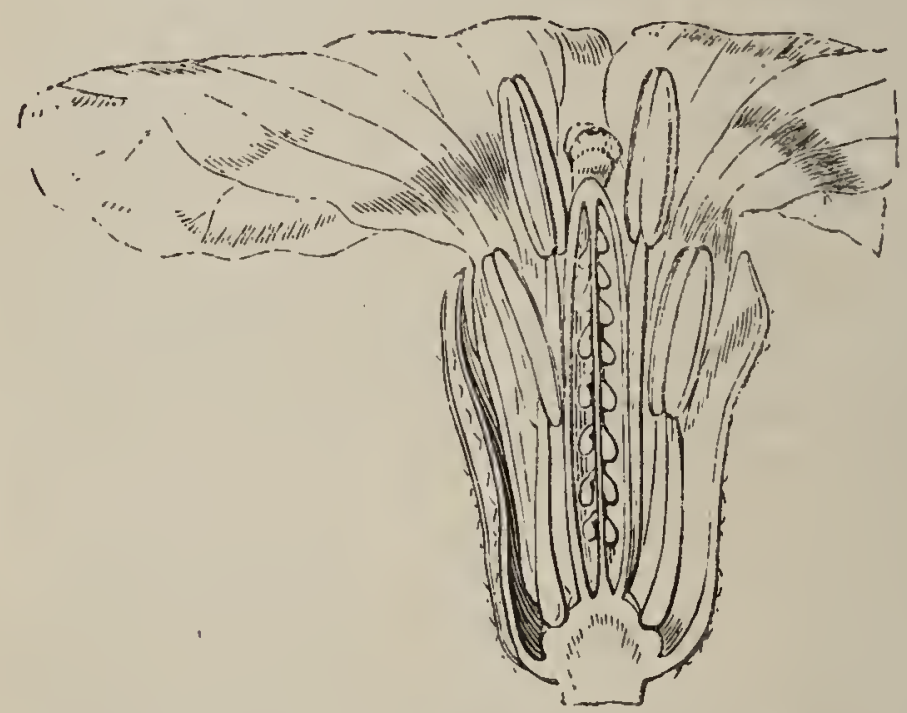

Fig. 9. Verticul section of flower of Wallflower, two of the long stamens, as well as two petals and two sepals, being removed.

which four are long and two short (hence called tetradynamous). The pistil at first sight looks as though it consisted of a single carpel ; but you may observe that the stigma is indistinctly tw.olobed. This would indicate that we have two carpels cohering together. Further examination of this curious pistil we postpone. The flower of Wallflower may be described:-Calyx inferior, polysepalous; corolla polypetalous, regular; sta- 
mens hypogynous, tetradynamous; pistil superior, syncarpous (that is, with carpels cohering).

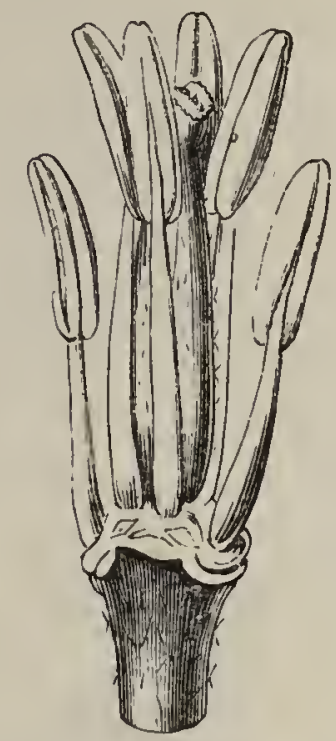

Fir. 10. Pistil and stamiens of Wallflower, the sejals and petals being removed.

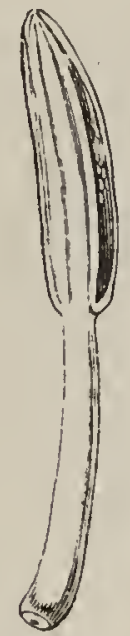

Fig. 11. Single stamen of same: the anther dehiscing t: liverate the pollen.

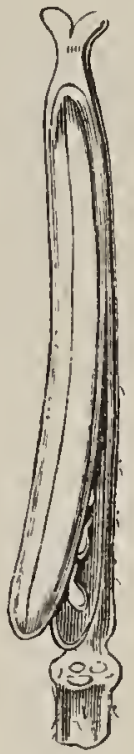

Fig. 12. Ripe pistil of Wall. liower.

4. Garden Pea.-The calyx presents a new feature. It is in one piece. But it is fivetoothed, and the teeth indicate the number of sepals which compose the calyx. The calyx is gamosepalous; that is, composed of coherent sepals. 'The corolla consists of five free unequal petals ; it is therefore polypetalous and irregular.

The stamens are not inserted strictly upon the floral receptacle, but, owing to a slight adhesion contracted with the bottom of the calyx, they spring from the lower part of the latter, as a section made through the middle of the flower with a sharp knife from below upwards will show, 'The stamens are hence called perigynous. Count 
them carefully. You will find there are ten of them (decandrous), nine coherent by their filaments into a bundle, one (the upper one) distinct. Cohering thus, in two bundles or sets, they are called diadelphous.

The pistil is free from the calyx, and consists of a single carpel, as you may determine from the undivided stigma and one-celled cavity of the ovary. It is superior and apocarpous (monocarpellary). 'The flower of the Pea may be described:-Calyx

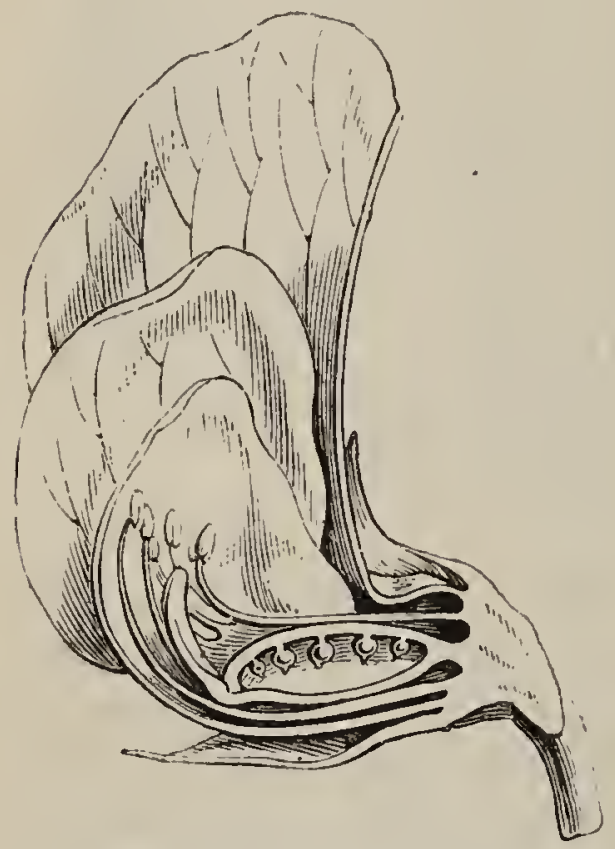

Fio i3. Section of flower of Garden Pea.

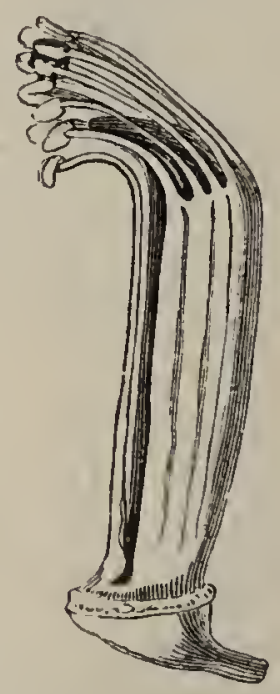

Fig. 14. Diadelphous stamens of sarne.

inferior, gamosepalous; corolla polypetalous, irregular; stamens perigynous, decandrous, diadelphous; pistil superior, apocarpous (monocarpellary).

5. Bramble (Blackberry). - The calyx at first sight appears to consist of five distinct sepals, but closer examination will show that 
these are coherent below, and that the calyx is really gamosepalous. As there is no adhesion to the pistil, it is inferior. The corolla is regular and polypetalous, the stamens are polyandrous, and, as a vertical section of the flower will show, perigynous, being inserted upon the calyx. The pistil

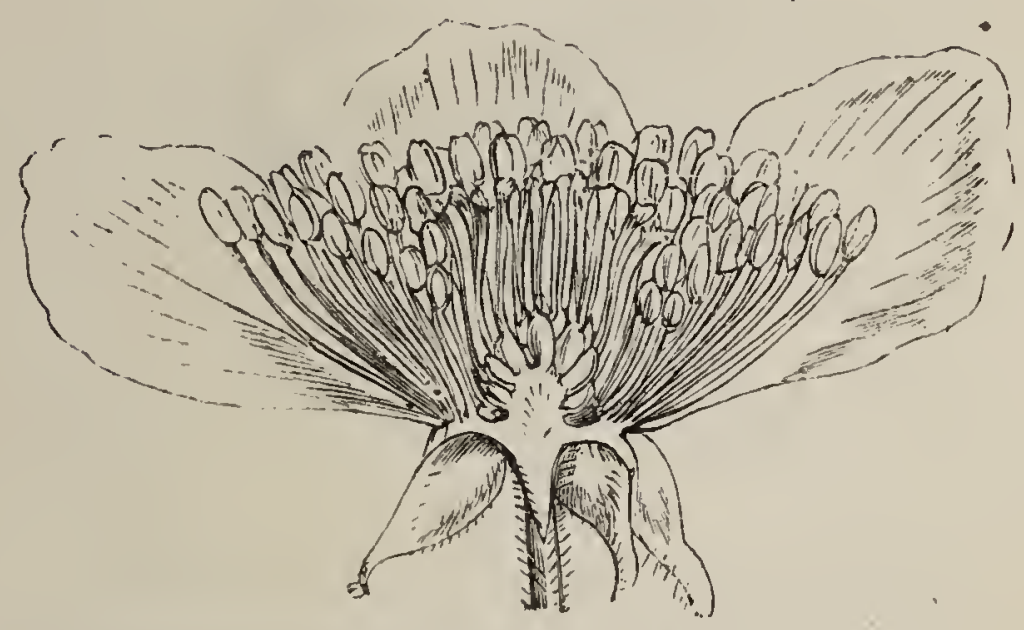

FrG. 15. Vertical section of a flower of Bramble.

is superior and apocarpous, presenting neither cohesion between its carpels nor adhesion with the calyx. Calyx inferior, gamosepalous; corolla polypetalous, regular; stamens perigynous, polyandrous; pistil superior, apocarpous (polycarpellary).

6. ApPle or Pear. - Either will serve. Make, first of all, a vertical section through the centre of a flower. You observe of the calyx that not only is it gamosepalous, by cohesion of its sepals, but that its tube is adherent to the pistil (ovary). The consequence of this adhesion is, that the calyx (though really only the limb of the calyx) appears to spring from above tho ovary. Hence it is termed superior. The corolla is regular and polypetalous. The sta- 
mens, inserted upon the calyx, are perigynous and polyandrous, the pistil (ovary) is inferior, and its carpels appear to be coherent. (See page 174.) The flower of the apple may be described, therefore:-Calyx superios; gamosepalous; corolla

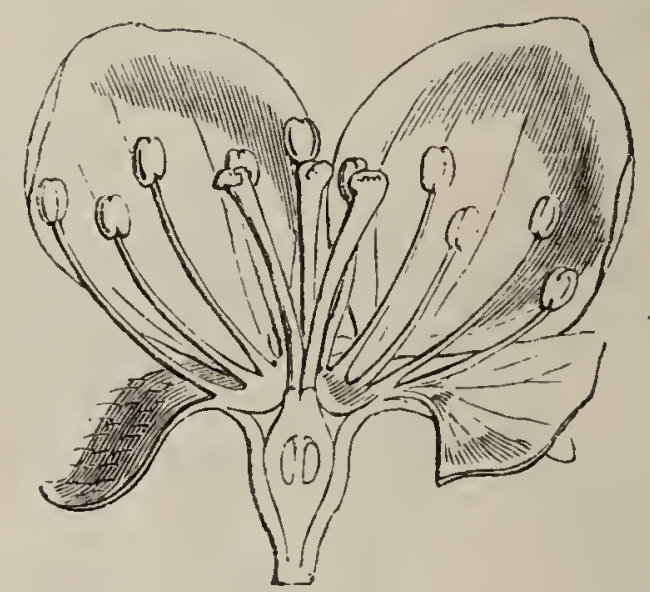

Fic. 16. Vertical section of a flower of the Apjle.

regular, polypetalous; stamens perigynous, polyan. drous; pistil syncarpous, ovary inferior.*

7. Cow Parsnir or Carrot. - Either of them will do. The cut represents the first-named. The calyx is almost entirely adherent to the ovary, the free portion (limb) being reduced to a mere rim. It is gamosepalous and superior. The corolla is polypetalous and regular, or, in the outer flowers, irregular. Owing to the complete adhesion of the calyx to the ovary, the

"When the term "inferior," or "superior," is applied to a flower absolutely, it is understood to refer to the ovary, denoting its relation, as to adhesion, witl the calyx only. We have all grades intermediate between the inferior and the superior ovary, as we find all degrees of adhesion, from complete adhesion to com. plete freedom. 
otaniens appear as though inserted upon the top of the latter; hence they are termed epigynous. They are five in number (pentandrous). The

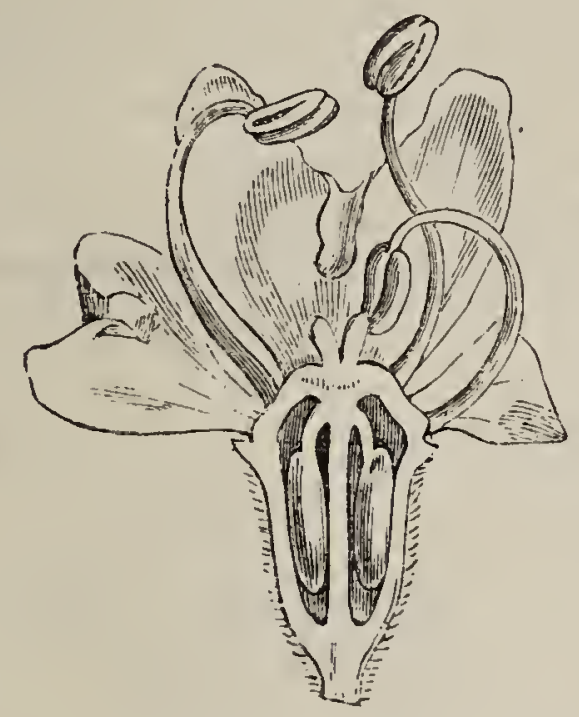

Fig. 17. Vertical section of a flower of Cow Parsnip.

pistil is syncarpous, as indicated by the two short styles, and by its two cells, as we shall see if we cut the ovary across.

The calyx is superior, gamosepalous; corolla polypetalous, regular or irregular; stamens epiyynous, pentandrous; pistil syncarpous, ovary inferior.

8. Daisy.-The structure of the flower-heads is very puzzling at first. Let us refer again to the Cow Parsuip. In this plant we have a number of flowers borne upon short peduncles (pedicels), which spring from the same point, or centre. Suppose all the flowers had been sessile, we should then have had them arranged upon the top of the stem, much in the same way as the parts of a single flower are arrangel 
upon the floral receptacle. In the Daisy we have an example of such a case. Very numerous small flowers, called florets, are arranged upon a com. mon receptacle, which in the Daisy is conical, and surrounded at its base by a whorl of small, narrow, herbaceous leaves, forming what is called an involucre, and reminding us much of a calyx, for which it is apt to be mistaken by beginners.

If a careful section be made lengthwise through the centre of the flower-head, the general plan

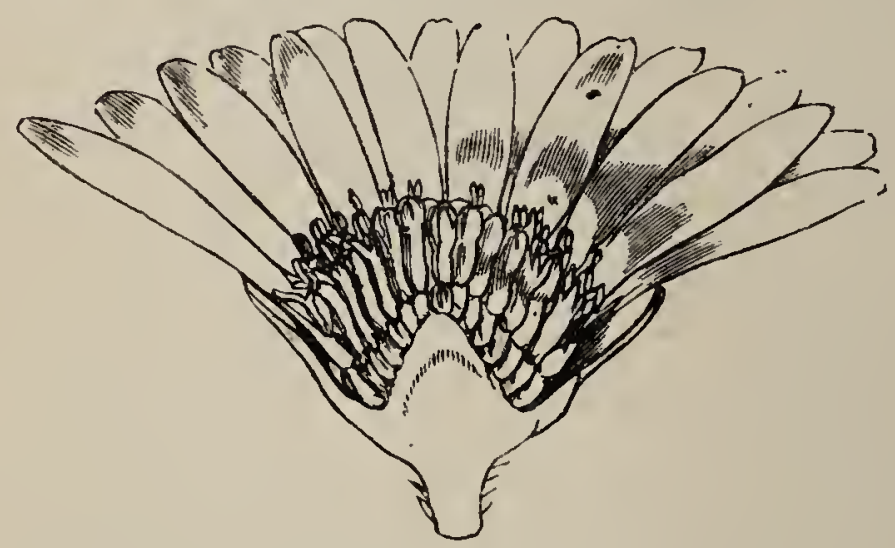

F1G. 18. Vertical section of a flower-head of Daisy. The outer florets with strap-shaped corollas form the ray, the inner, small, tubular florets the disk.

of the whole becomes evident, though from the smallness of the florets in the Daisy a lens will be needed in order to make out their structure properly. The cut shows such a section. There is a marked difference in form between the outer and inner florets of the flower-head, due to the one-sided enlargement of the corolla in the former. The outer florets with one-sided, white corollas, taken together, form the ray of the flower-head; the smaller yellow florets, with regular corollas, occ:pying the centre of the head, form the disk. 
In describing the structure of flower-heads (capitula), it is well to examine the ray and disk florets separately. Neither of these appear, at first sight, to have a calyx. Analogy, however, affords sufficient reason to conclude that each floret has its own calyx, but it is wholly adherent to the ovary. It is superior and gamosepalous. In many plants relater to the Daisy - the Thistle, for example -the upper, free portion $(\operatorname{limb})$ of the calyx exists as a crown of fine bristles surrounding the top of the ovary.

The corolla of the ray florets is (white) gamopetalous and irregular; of the disk-florets (yellow) gamopetalous and regular. The stamens in the ray florets are absent or imperfect; in the disk florets they are five in number (pentandrous), and inserted upon the corolla. In consequence of this adhesion to the corolla they are termed epipetalous.

An important character which the stamens present

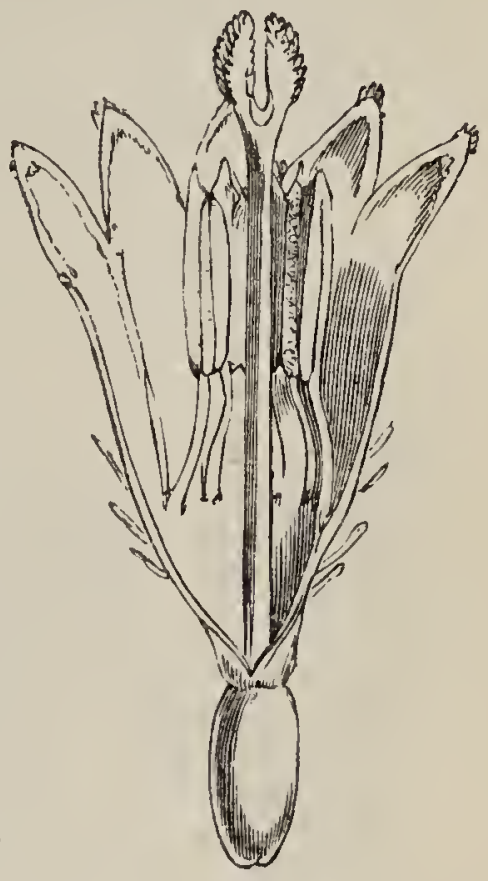
is yet to be noted, but from the minuteness of these organs, it may be well to verify it in some plant with larger flower-heads, as the Dandelion (in which all the florets are irregular) or the Thistle (in which they are all regular). It will be found that the stamens cohere by their anthers. On 
this account they are termed syngenesious. The coherent anthers form a tubular sheath which closely surrounds the stylc. The pistil we may infer to be syncarpous from the two-lobed stigma, notwithstanding that the inferior ovary is one-celled.

In the Daisy we have:-calyx superior, gamosepalous; corolla gamopetalous, regular (disk), or irvegular (ray); stamens epipetalous, pentandrous, anthers syngenesious; pistil syncarpous, ovary inferior.

9. White or Purple Deadnetrte.-Either will do. The cut represents the former, which has

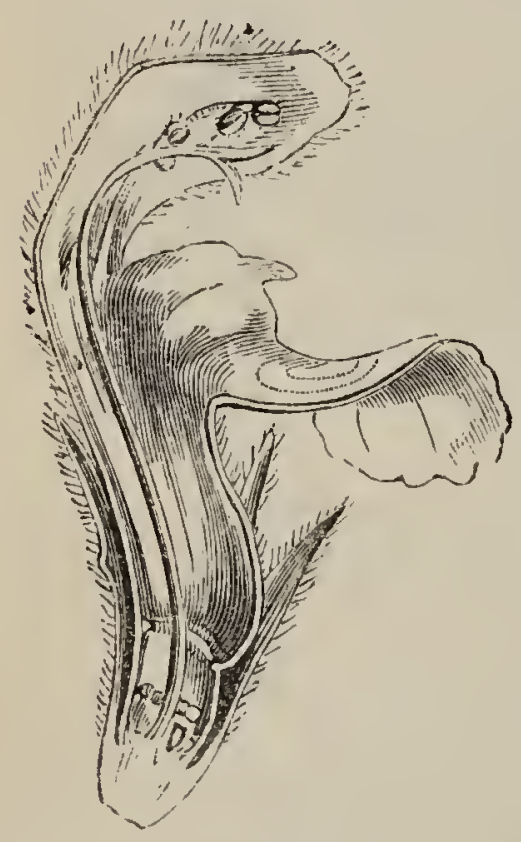

Fia. 20. Vertical section of a
flower of White Deadnettle. rather larger flowers. The calyx is free, but the sepals, five in number, as indicated by the five acute teeth, are coherent. The corolla is gamopetalous and irregular, the divisions being unequal. The stamens, easily found on pulling out a corolla from the calyx and cutting it open on the side, are four in number, one stamen being suppressed. On this account tile flower is said to be unsymmetrical, the symmetry, or agreement in the number of parts in each series of the flower-leaves, being interrupted. The stamens are adherent to the lower part of the corolla, consequently epipetalous, and two are long and two short, the lower and onter pair being longer than 
the upper and inner; hence they are termed didynamous. The pistil is syucarpous, consisting of two carpels, as indicated by the bifid stigma, and the ovary is superior and deeply four-lobed, so that the style springs from the centre and base of the lobes of the ovary. Deadnettle has calyx inferior, gamosepalous; corolla gamopetalous, irregular; stamens epipetalous, didlynamous; pistil syncarpous, ovary superior.

10. Primrose, Cowslip, or Auricula.-Whichever may be most convenient. The calyx is free, the sepals coherent, The corolla regular, the

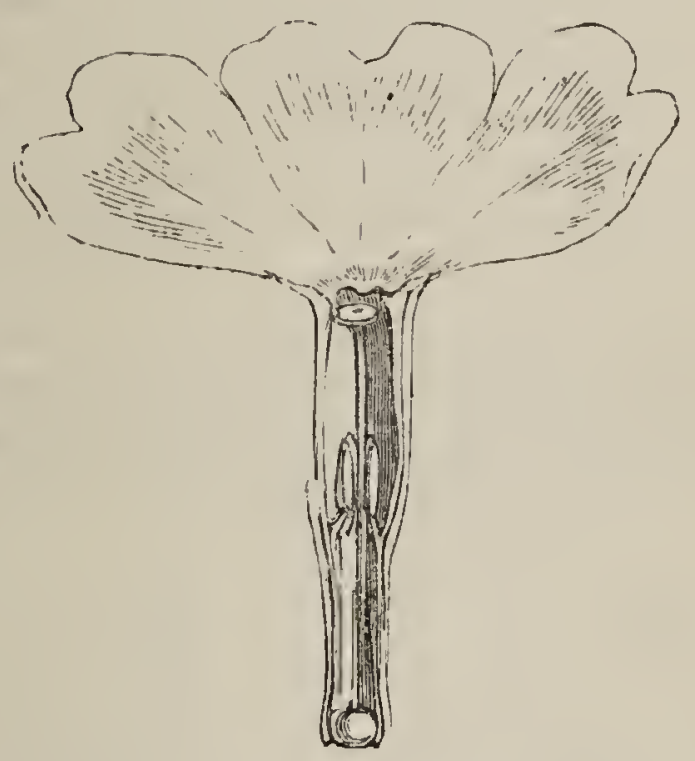

Fig. 2u. Vertical section of a flower of Primrose, the calyx being removed.

petals coherent. Note carefully the position of the stamens with respect to the lobes of the corolla. We have already observed the tendency to alternation of parts which usually obtains in the arrangement of the floral organs, but here wo find the epipetalous stamens are opposite to the 
lobes (answering to the petals) of the corolla. If the anthers be low down in the tube of the corolla, carry a straight line up from one of the anthers, and it will be found to coincide with the middle of one of the 5 lobes of the corolla. This opposition of parts should always be noted when it occurs. In this case it is probably due to the suppression of a whorl of 5 stamens exterior to the whorl which is developed.

The pistil, from its centrical position, we may judge by analogy to consist of 5 coherent carpels, although the superior ovary is one-celled, and the carpels so completely consolidated as to leave no trace of lobing, even in the stigma. Primrose has calyx inferior, gamosepalous; corolla gamopetalous, regular; stamens epipetalous, pentandrous; pistil syncarpous, ovary superior.

11. Stinging Netrue.- Either of our two native species. If the larger one be used it will be needful to gather two specimens, carefully examining the minute flowers in order to ascertain that in one specimen they enclose stamens, in

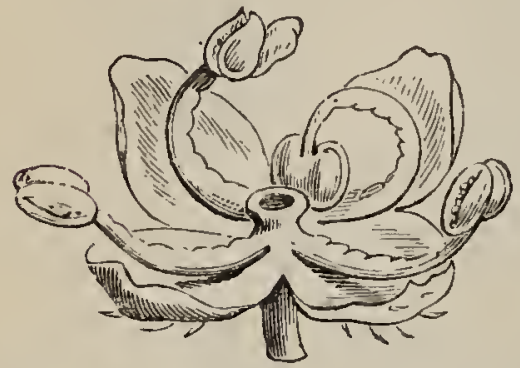

Fig. 22. Staminate or male (ठ) flower of Stinging Nettle.

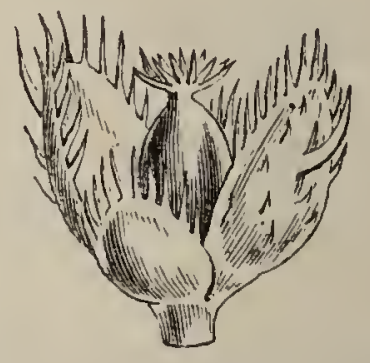

Fra. 23. Pistillate or femile (q) flower of same.

the other a pistil, because these organs occur in separate flowers (the flowers being imperfect, unisexual, or diclinous), and in the Greater Nettle 
on separate plants (dioecious). In the Lasser Nettle staminate and pistillate flowers are on the samo plant (monoecious):

Examine the staminate and pistillate flowers separately. In the staminate flowers you observo the calyx to consist of 4 sepals. As the corolla is suppressed, the envelope of the flower is single (monochlamydeous), not double (dichlamydeous), as in all the species hitherto examined. Opposite to the sepals are the four stamens, inserted upon the receptacle (hypogynous). The pistil is represented by a minute, central rudiment. In the pistillate flower, the calyx consists, as in the staminate one, of 4 leaves, but they are here unequal, an opposite pair being larger. There are no stamens, and the pistil consists, apparently, of a single carpel with a superior ovary, occupying the centre of the flower.

In the Nettle, then, we have the flowers:unisexual or diclinous, being monoecious or dioecious according to the species ; the calyx inferior, polysepalous; corolla 0 ; in the male flower, stamens hypogynous, tetrandrous, pistil 0 ; in the female flower, pistil apocarpous and superior, stamens 0 . The calyx of monochlamydeous plants is usually termed a perianth.

12. Willow.-Any species will do; but, as in the case of the Greater Nettle, two specimens, from different trees, will be required, as the flowers are diclinous and dicecious. The cuts represent the male and female flowers of the Great Sallow. You find the flowers arraned in spikes, which, being deciduous and bearing imperfect flowers, are specially distinguished as catkins. lioth the staminate and pistillate flowers are desti- 
tute of calyx and corolla. Having, therefore, no envelope to the essential organs, they are called achlamydeous. The stamens, 2,3,5, or rarely more, spring from the axil of a minute scale-like leaf (bract), and constitute the male flower, of which a number are crowded together upon the samo catkin. The pistil of the female flowers also springs from the axil of a similar bract; it is syncarpous, consisting of 2 carpels, as indicated by the bifid stigma and 2 short lines of ovules in

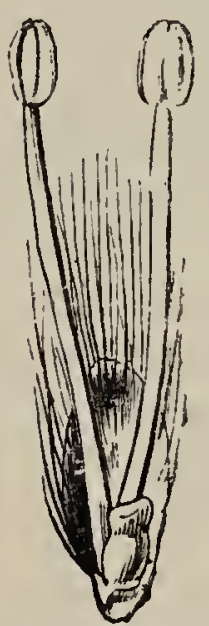

Fig. 24. Staminate flower of Willow (Great Sallow).

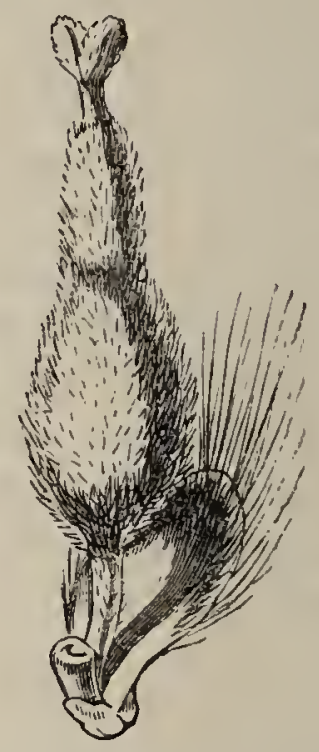

FIG. 25. Pistillate flower of same.

the single cavity of the ovary. The flowers of Great Sallow may be described thus :-Calyx 0 ; corolla 0 ; male flower, stamens 2 (diandrous), pistil 0 ; female flower, stamens 0 , pistil syncarpous.

13. As the plants which we have hitherto examined differ in many important particulars from those which yet remain of the fifteen enumerated 
at the beginning of the chapter, it may be well to review here some general characters afforded both by the reproductive and nutritive organs, which are common to all those we have already done, and which are more or less markedly in contrast with the characters presented by corresponding organs of the plants yet to be examined.

In nearly all the examined plants you find the leaves with a distinct blade and petiole; and if you hold the blade of any of them up to the light you may notice that the small veins which ramily through it are netted irregularly. In the flowers you have observed that the parts of the calyx (sepals) and of the corolla (petals), whether free, coherent, or adherent, are either in fours or fives; that is, 4 or 5 to a whorl.

Reviewing generally the plants above described, including the Buttercup, you will observe that we have but two which grow to the dimensions of a tree-viz. the Apple and Willow. Another, the Bramble, is a shrub. These three differ from the rest, in the formation of a distinctly woody stem, which does not die down each season. On this account we may speak of them as woody or ligneous plants. The rest are herbaceous plants ; the flowering stems usually dying down annually, although in some of them the stockthat is, the shortened persisting portion of the stem from which the roots are given off, and in spring the flowering branches-lasts two or several years.

14. Now the characters of (1) leaves more or less distinctly narrowed at the base into a petiole ; of (2) irregularly net-veined leaves; and (3) the arrangement of the parts of the flower in fours or 
fives (which three characters we have found to apply more or less to all the specimens which we have examined hitherto), are supported by other characters afforded by the seeds and mode of growth of the wood, which it is important you should correctly understand.

15. We have already briefly noticed the small seed of the Buttercup enclosing a minute embryo. Take, now, a few Peas, the seeds of the Pea-plant, or, better still, because larger and more easily examined, Beans - the seeds of the Windsor or Garden Bean, a plant very closely related to the Pea, and agreeing with it in all essential particulars. This description and the accompanying cuts refer

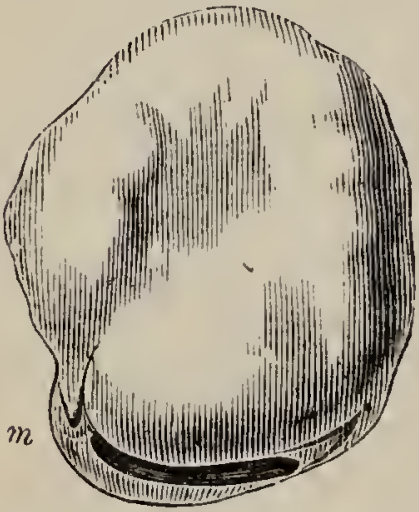

Fig. 26. Seed of Bean. The black line at the bottom of the seed is the lilum. The letter $m$ indicates the position of the micropyle.

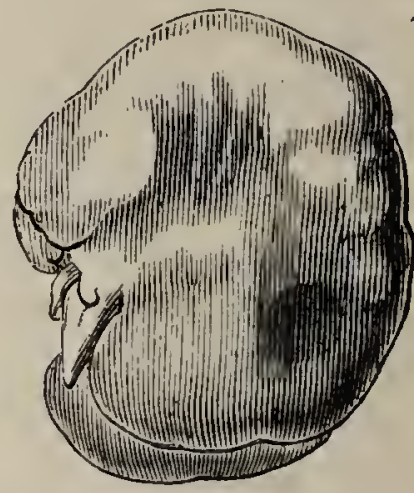

Fig. 27. Seed of same, the testa being removed. On the left is the radicle, pointing downwards; its extremity corresponding to the micropyle.

to the Bean. If the beans be dry and hard; let them soak over-night, or, to save time, put them in boiling water for a few minutes. This will soften them and render their examination easy.

Observe, first, the black stripe on the edge of the seed. This indicates the part by which the 
seed was attached to the fruit-carpel (pericarp) in which it was enclosed; it is the scar left on its scparation from it. It is called the hilum. On careful examination you may observe at one end of the hilum a very minute aperture through the skin of the seed. You may find it by squeezing the soaked seed, when moisture issues from it. This is the micropyle; it answers to the micropyle of the ovule. It is usually obliterated or too minute to be observed in ripe seeds.

Proceed, now, to remove the skin of the seed (testa). You find it contains two large thickened lobes or leaves, each flattened on the inner side, rounded on the outer, and you also notice that these lobes are hinged at one side. Separate the lobes carefully, and you may observe upon the margin of the inner face of one of the lobes, close by the hinge, a rudimentary bud and root. You find, then, enclosed by the testa, (1) one pair of large seedleaves, (2) a bud with minute, rudimentary foliage-leaves, and (3) the rudiment of a root. Nothing more. These parts are indicated in the cut, which shows one seed-leaf

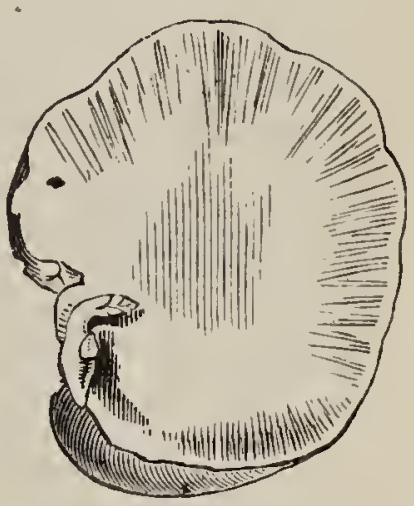

Fig. 2S. One cotyledon of the Bean, showing the plumule and radicle.

seen on its inner face. The seed-leaves are called cotyle-

dons. To the left is the bud of the stem, slightly curved inwards, called the plumule; and, pointing downwards, the rudiment of the root, called the radicle; the extremity of the radicle invariably nestles immediately within the micropyle. 
'The seed-leaves, or cotyledons, of the Bean are opposite; so we have an embryo with a pair of cotyledons, or a dicotyledonous embryo.

16. If we put a few beans upon moist earth in a flower-pot and cover them with a bell-glass, the first stage of growth, termed germination, of the young Bean-plant may be conveniently observed. The essentials to germination are found by experience to be a certain amount of moisture, warmth, and air. If sufficiently warm (and the amount of warmth required to commence with varies in the seeds of different plants), moisture is absorbed by the sced, which causes it to swell up so as to burst the seed-skin. Oxygen, also, is absorbed from the air, and certain chemical changes, accompanied with the liberation of some carbonic acid, take place in the cells of the embryo, resulting in the solid substances which they contain being made available for the ase of the growing plant. The radicle is always the first to break out, curving down towards the earth, whatever may be its position. The radicle by its direct prolongation forms the primary root of the plant. The plumule shortly after disengages itself, ascends and develops into the stem of the Beall, bearing foliage and flowerleaves.

17. Turning back to our first chapter (page 10), we may compare the structure of the seed of the Buttercup with that of the Bean. At first sight they appear to have nothing in common, excepting that each seed encloses an embryo. In the Bean, however, the embryo fills the seedskin, while in the Buttercup it occupies a very small space at the base of the seed, being enclosed 
in a uniform, solid substance, which occupies nearly the whole seed. This substance in which the embryo is embedded we called the albumen ( Fig. 7). It is at the expense of this albumen that the minute embryo is enabled, during its germination, to develop a root and stem. Seeds containing, besides an embryo, a deposit of albumen, whether large or small, are said to be albuminous. Seeds like the Bean and Pea, which contain an embryo only, are exalbuminous. In exalbuminous seeds whatever nutrient matter may be required to sustain the early stages of germination, is incorporated in the embryo itself. Between the two extremes of abundant albumen (Buttercup) and no albumen at all (Bean), we have every degree.

18. The embryo of Buttercup requires a magnifying-glass for its examination. All that you will be able to make out of it is, that it is slightly notched on its inner side, that is toward the body of the albumen on the side turned from the micropyle. The notch obscurely divides this side of the embryo into two lobes, which are the rudimentary cotyledons. The opposite extremity is the radicle, directed towards the micropyle. The plumule does not develop until after germination, which process, in the Buttercup, agrees generally with that of the Bean; the albumen serving the purpose of a warehouse of nourishment in the Buttercup, and the fleshy cotyledons the same purpose in the Bean.

Like the Bean, therefore, the Buttercup is dicotyledonous; and as the character expressed by this term (the possession of a pair of cotyledons, or, more strictly, tho simple fact that the 
first leaves of the plant are opposite) is common to plants with irregularly net-veined leaves, and with the parts of their flowers in fours or fives with but a comparatively small number of exceptions, botanists employ the term DICOTYLEDONS as the name of a great Class of flowering plants, including all those which present the above characters.

19. It must always be borne in mind, however, that none of these characters are absolute. They are always subject to exception. So that plants which exhibit a departure from the prevalent type of Dicotyledons in any single character only are still referred to the same class. Thus we have a few Dicotyledons which are actually destitute of cotyledons, or which have but one, or more than two; we have some with parallelveined leaves, and others with the parts of tho flower in threes. But in all these cases the question as to which Class the plant shall be referred, is decided, not by any solitary character, but by the sum or preponderance of characters which it presents.

The structure of the stem, and mode of growth of the wood, we shall speak of in a later chajter. 


\section{CHAPTER V.}

EXAMINATION OF COMMON PLANTS CONTINUED AS BEFORE.

1. Arum.

2. Spotted Orchis.

3. Daffodil.

4. Tulip.

5. Wheat.

6. Points of agreement in the four plants just examined. The structure and venation of their leaves, and the number of parts in the flowers.

7. A grain of Wheat is examined. Parts of the seed.

8. Structure of the embryo of Wheat. There is but one cotyledon. It is thcrefore monocotyledonous. Its mode of germination.

9. General characters of Monocotyledons.

10. Tabular review of Dicotyledons and Monocotyledons.

11. These great Classes are divided into subordinate

12. The principal divisions of Dicotylcdons, and the characters upon which they depend.

13. And of Monocotyledons.

14. The Classes, Subclasses, and Divisions, are tabulated.

1. COMMON ARum or Cuckoo Pint.-Without much care you will be liable to misunderstand the structure of this plant, as did Linnæus himself. The flowers are closely packed in rings upon the lower part of the fieshy spike, which you find enclosed in a large sheathing bract-leaf called a spathe. A flower-spike of this kind, enclosed in a spathe, is distinguished as a 
spadix. With a magnifying-glass compare the structure of the minute flowers of the lower ring $(p)$ with those of the upper ring (st.). Be careful to note, however, that between the rings is a broken circle of abortive pistillate flowers, and

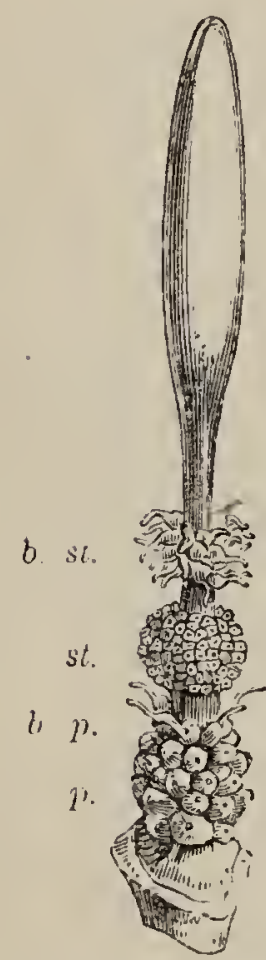

Fig. 29. Spadix of Arum, the sheathing spathe being remulect. st. stamens, reduced to nearly sessile anthers. $b$. st. rudimentary stamens. $p$. pistils. b. p. barreu (rildimentary) pistils.

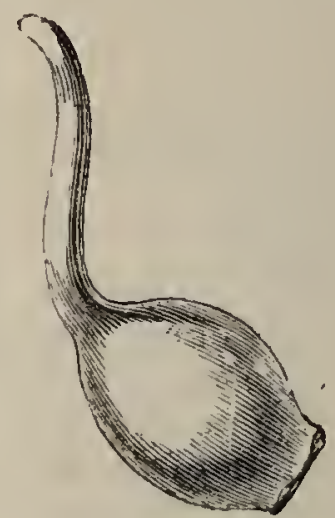

Fı, 30. Barron pisti!nte flowe1 of saule.

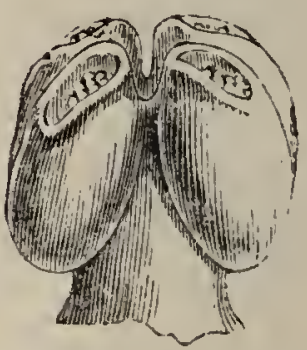

Fia. 31. Single stamen of same; with four-celled anther opening by pores at the top.

inmediately above the upper ring a number of filaments, which represent abortive staminate Inwers. The flowers of the lower ring $(p)$ consist each of a fistil only, and each pistil consists, apparentiy, of a singite carpel. 
The upper ring (st.) consists of a number of stamens vary densely packed, each stamen representing a single flcwer. Each stamen, moreover, is reduced to its anther, the cells of which open by a little pore at their tips. 'Thus the structure of the flowers of Arum is of the very simplest kind :-calyx 0; corolla 0 ; $\delta$, stamen 1, pistil 0 ; + , stamen 0 , pistil of a single carpel.

2. Spotted Orchis.-The calyx is coloured like the corolla, and consists of three sepals, which are coherent, the coherent portion (tube)

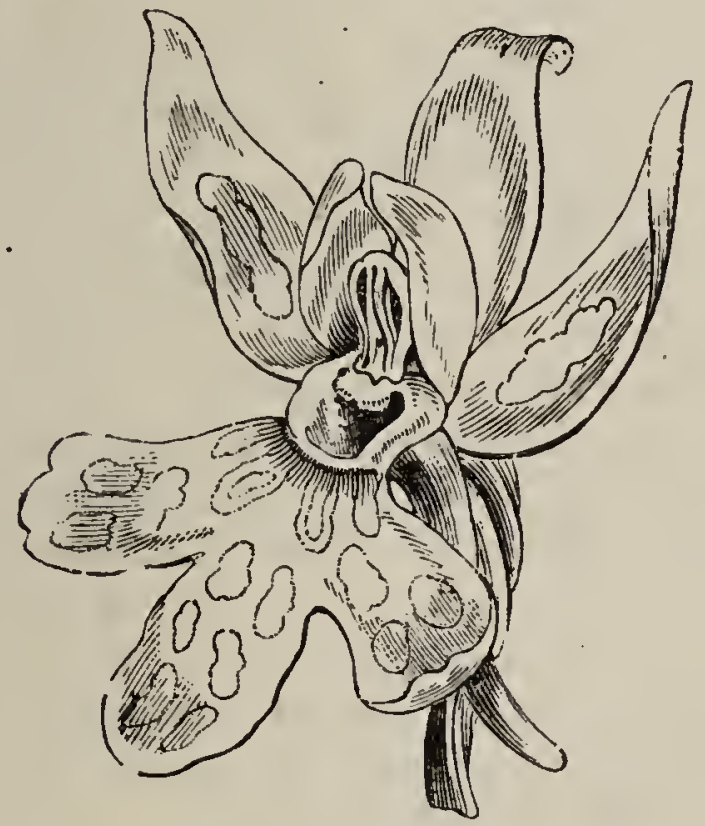

Fig. 32. Flower of Spotted Orchis.

being wholly adnate to the ovary, so that the free part of the calyx (the 3-lobed limb) springs from the top of the ovary. Do not mistake the ovary for a flower-stalk (pedicel). If you cut the apparent pedicel across, you will find that it contains many ovules in three rows; it is an 
inferior ovary, being adnate to the calyx-tube. The corolla is formed of three unequal petals, one, which, from a partial twist of the ovary, is the lowest, being much larger than the upper pair and furnished with a spur.

It is usual in flowers like this, in which the parts of the calyx and corolla resemble each other in colour and texture, as well as when a calyx only, or a corolla only, is present, to speak of the envelopes of the flower collectively as perianth, calling the parts of which it is made up the leaves of the perianth. In this instance the perianth is gamophyllous and superior, since the leaves of the perianth are connate and its tube is adnate to the ovary.

There is but one stamen, of very anomalous stricture, reduced to a two-celled anther, standing immediately over the opening of the spur. Under the minute knob-like projection at the base of the anther (rostellum), and at the back of the opening of the spur, is a viscid surface which serves as the stigma. From the adhesion of the stamen to the pistil it is termed gynandrous. The flower of Spotted Orchis may be thus described:-Perianth superior, gamophyllous, irregular; stamen 1 (monandrous), gynandrous; pistil syncarpous, ovary inferior.

3. DAFFodil. - Do not mistake the wide, projecting tube which encloses the stamens and pistil for a corolla. A comparison of the Daffodil with other plants in which it is less conspicuous or wanting, shows that it is merely an appendage (called a corona) of the envelopes of the flower. The leaves of the perianth, six in number, are alike in colour, texture, and size. It is therefore 
regular; and, as in Orchis, they cohere, forming a lower tubular portion which is adherent to the ovary, the perianth is also superior. There are six stamens, inserted upon the perianth (epiphyllous). The pistil, from its three-lobed stigma

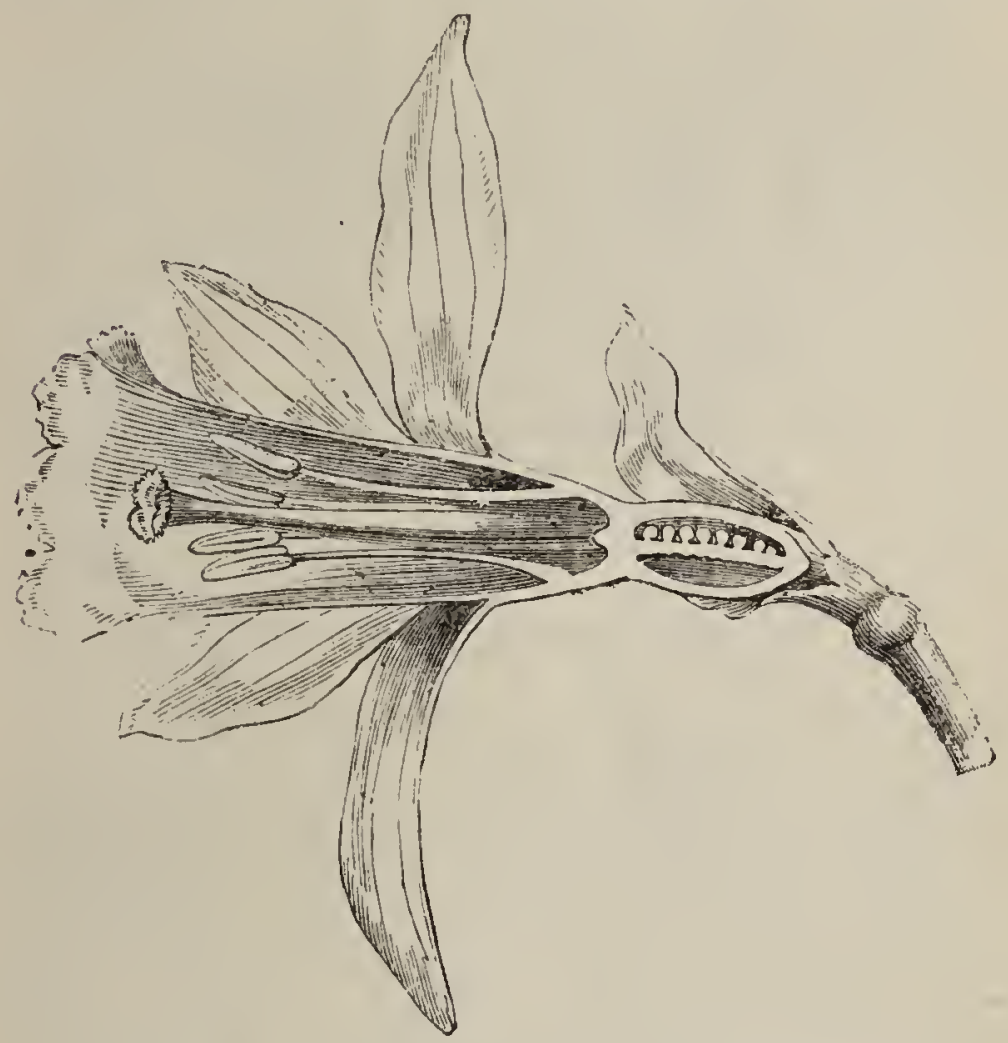

Fig. 33. Vertical section of a flower of Daffodil.

and the three cells in its inferior ovary, is clearly syncarpous. Daffodil has, therefore:-Perianth superior, gamophyllous (with a corona); stamens epiphyllous, hexandrous ; pistil syncarpous, ovary inferior.

4. Tulip. - Very similar in many respects to the Daffodil, differing principally in the absence of both cohesion and adhesion in the perianth, and in the absence of a corona. 'The stamens aro 
free, and the pistil has a 3-lobed stigma and 3-celled ovary. Tulip may be described thus :Perianth inferior, polyphyllous; stamens hypo-

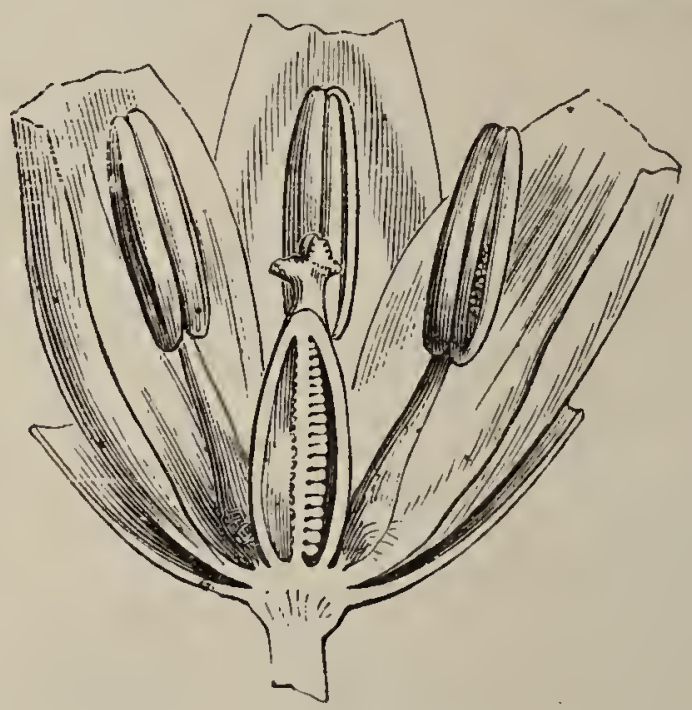

FIG. 34. Vertical section of a flower of Tulip.

gynous, hexandrous; pistil syncarpous, ovary superior.

5. Wheat.-We have here an arrangement of parts widely different from that obtaining in any of the plants hitherto examined. The flowers are arranged in short, broad spikelets, which spikelets are disposed alternately in two rows along the top of the stem, forming a dense, obtusely four-cornered spike. Break the entire spike in two about the middle, and take one of the lowest spikelets from the upper half. Observe that it is attached to the stem (axis of the spike, called the rachis) by its side. In some grasses, as Rye-grass, the spikelets are attached by their edge to the rachis. Each spikelet consists of a pair of nearly opposite, hard, dry, scaly leaves, called the outer glumes, which enclose 3 to 5 closely 
imbricated flowers, arranged alternately on opposite sides of the axis of the spikelet, Eack flower is enclosed between a flowering-glume and a pale. The flowering-glume and pale are opposite to each other, and inserted very nearly at the same point; the flowering-glume, however, is the lower, and usually embraces the pale with its incurved edges. It is similar in form and texture to the outer glumes, and often terminates in a bristle (awn). The pale is generally easily distinguished by its having two lateral nerves and no midrib; indicating, apparently, that it may be composed of two organs cohering together. Between the floweringglume and the pale are the 3 free stamens and the superior ovary crowned with 2 plumelike stigmas. Note also 2 very minute scales, called lodicules, repre-

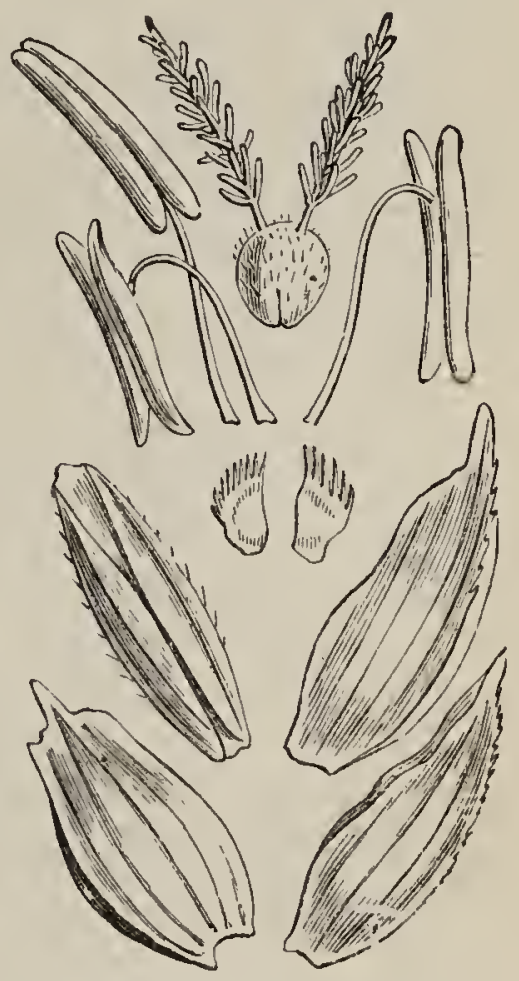

Fig. 35. The two outer glumes of a spikelet and the parts of a single floret of Wheat. The two lowest seales, right and left, are the outer gluines; of the next pair, the seale to the right is the flowering-glume, that to the left the pale. Then come the two minute lodicules, the three stamens, and the pistil. senting a perianth, inserted under the ovary. Between the outer glumes and the lowest flowering-glume of the spikelet in some grasses, and, in others, above the uppermost perfect flower of 
the spikelet, there are one or more empty glumes, which are called, by some botanists, sterile flowers. Occasionally a staminate flower is borne in the axil of the glume next below or above the perfect flower. Wheat may be thus described: -Spikelets with two outer glumes; flowers with one flowering-glume, one pale, two lodicules; stamens triandrous, hypogynous; pistil syncarpous, ovary superior.

6. Let us now proceed to review, as before, the five plants last examined, viz. Arum, Orchis, Daffodil, Tulip, and Wheat.

They all happen to be herbaceous plants. The leaves, excepting in Arum, do not present the obvious distinction of petiole and blade, and, with the same exception, the veins of the leaves are parallel and not irregularly netted. Those which have the essential organs of the flower

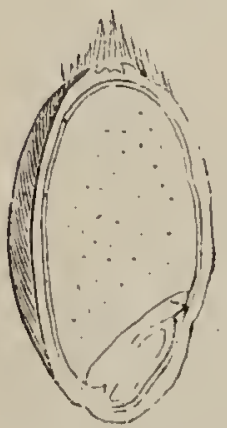

Г⿴囗. 3u. Lungitudinal section of a grain of Wheat. The embryo is represented at the base of the seed. enclosed in a perianth, have the leaves which compose it arranged in two whorls (calyx and corolla) of three each. We find the five plants marked by (1) no obvious distinction between blade and petiole; (2) parallel-veined leaves; and (3) the parts of the flowers in threes.

7. We must now soak a few grains of Wheat for comparison with the seeds of Dicotyledons. We must, however, be careful not to regard the grain of Wheat as a seed corresponding to that of the Pea or Bean, for it is a fruit, consisting of pericarp (ovary) and seed; the pericarp being closely 
adherent to the true seed. In the Tulip, Daffodil, and other plants just examined, the seeds are free from the pericarp, as in Dicotyledons generally; the adhesion, in this case, may be regarded as accidental, though it is very characteristic of the fruit of grasses. Cutting the grain open, we find the embryo near the base, occupying about onefourth or one-fifth of its contents, the rest of the seed being filled with a starchy albumen.

8. The structure of this embryo we must endeavour to understand, though, in order to make it clearly out, very careful sections must be made through it lengthwise. The accompanying cut will supply a good idea of the arrangement of its parts. We do not find the first leaves of

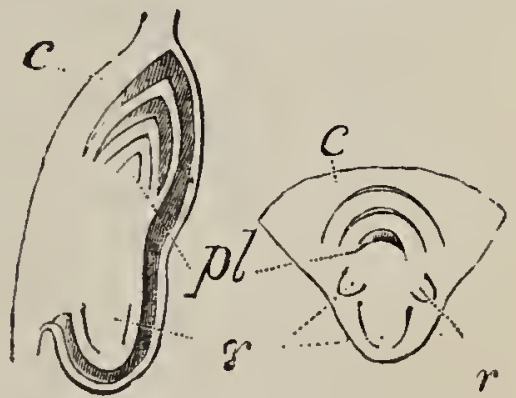
the embryo opposite to each other, forming a pair of cotyledons, as in the Bean and other Dicotyledons, but they are alternate; the outermost only being regarded as a seed-leaf or cotyledon. Those which it sheaths belong to the plumule. The cotyledon being single, the embryo of Wheat is called monocotyledonous. The lower part of the embryo is the radicle. This never directly elongates in germination, but the internal, rudimentary rootbuds, $r r$, burst through it and develop into the root-fibres of the plant. The process of germination is similar to that of Dicotyledons, with this difference in regard to the origin of the root. The sheathing portion of the cotyledon is protruded 
from the seed, and embraces the base of the plumule, which ultimately develops into a stem.

Now a structure similar to that of Wheat we find in the seeds of other corn-plants. In Barley and Oats the grain (fruit) presents a different appearance, owing to the eircumstance that in these plants the fruit becomes adherent, after flowering, to the pale, which closely invests it, forming a sort of spurious pericarp which is removed by grinding. The seeds of all of these, however, are albuminous, corresponding, in this respect, to the seed of the Buttercup.

9. There are plants presenting so many characters in common with the five last examined as to be universally classed with them, although they may differ from them in the absence of albumen in the seed, and in other points, just as the Bean differs from the Buttercup amongst Dicotyledons. Int whether albuminous or exalbuminous they are all Monocotrledons, with rare exceptions; so that this term comes to be applied to a second great Class, just as Dicotyledons is applied to the members of the Class of which we previously examined representative types. The five plants which we have just examined all have monocotyledonous embryos, excepting Orchis, which is exceptional, in being destitute of a cotyledon; they all have parallel-veined leaves, excepting Arum ; and those with a perianth have its parts in threes. Now these characters, supported by others derived from the internal structure of the stem, are, as a rule, common to all Monocotyledons, and in contrast to those characters which we have shown to prevail amongst and to mark Dicotyledons. 
10. All flowering plants are either

DiCuTYLEDONS, or

\begin{tabular}{l|l} 
Embryo. & $\begin{array}{l}\text { With } 2 \text { cotyledons, the } \\
\text { radicle itself usually } \\
\text { elongating . . . . }\end{array}$ \\
Leaves . & $\begin{array}{l}\text { Net-veined . . . . . } \\
\text { Perianth }\end{array}$ \\
Wood. & $\begin{array}{l}\text { Farts in 4's or 5's . . . } \\
\text { In a continuous ring. . }\end{array}$
\end{tabular}

MONOCOTYLEDONS.

With 1 cotyledon, the radicle usually remaining undeveloped. Straight-veined. Parts in 3'6.

In isolated bundłes.

11. Upon characters afforded by the flower, of subordinate importance (because less constant) to those which distinguish Dicotyledons from Monocotyledons. bc tanists divide each Class into Sub-classes and Divisions. The kind of characters upon which these Sub-classes and Divisions rest we are already familiar with, having examined representatives of each. The Divisions are further divided into numerous Orders. These are treated of in subsequent lessons. The Subclasses and Divisions may be synoptically arranged thus :-

12. Dicotrledons are, in respect of envelopes of the flower-

Dichlamydeous (Dichlamydece), as Pea, Bramble, Apple, Parsnip, Marigold, Deadnettle, Primrose, - or

Incomplete (Incompleta). If incomplete, either Monochlamydeous (Monochlamydece), as Stingingnettle,-or

Achlamydeous (Achlamydece), as Willow.

Dichlamydeous flowers are either

Polypetalous (Polypetala), as Wallflower, Poa, Bramble, Apple, Parsnip,-or

Gamopetalous (Gamopetalae), as Marigold, Deadnettle. I'rimrose. 
Polypetalous flowers have their stamens inserted on the receptacle (hypogynous), and are hence called-

Thalamifloral (Thalamiflorce), as Buttercup and Wallflower,--or, inserted upon the calyx (perigynous or epigynous), and are hence called-

Calycifloral (Calyciflorce), as Pea, Bramble, Apple, and Parsnip.

13. Monocotyledons have their flowers, often imperfect, and with or without a minute, scaly perianth, arranged upon a spadix, hence calledspadicifloral (Spadiciflorce), as Arum,-

or with a perianth of petal-like leaves, hence called--

Petaloid (Petaloidece), as Orchis, Daffodil, Tulip, -or with chaffy glumes or scale-like bracts enclosing the flowers, hence calledGlumaceous (Glumiferwe), as Wheat.

Petaloid Monocotyledons have their perianth Hypogynous (Hypogyna), as Tulip, - or Epigynous (Epigynce), as Orchis and Daffodil.

14. The Classes, Sub.Classes, and Divisions may be tabulated thus :-

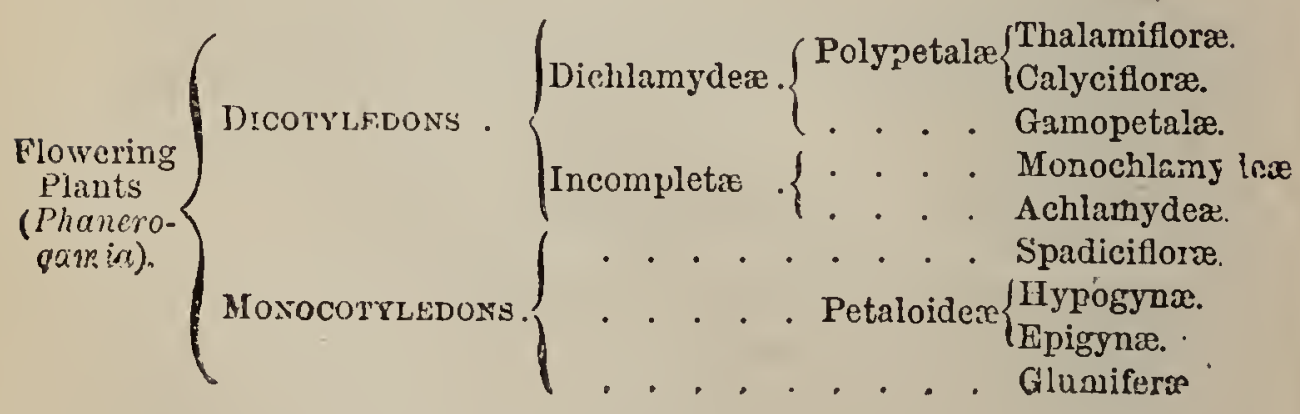




\section{CHAPTER VI.}

HOW TO FILL UP THE SCHEDULES.

1. The use of the "Flower-Schedule" 11 directing attention to important points in the structure of flowers, and training to habits of useful and accurate observation.

2. Explanation of the Schedule and of the mode of filling it up. The number of parts in each series of Flower-leaves is to be entered.

3. Also, the condition as to cohesion of the parts.

4. And the condition as to adhesion of the parts.

5. Terms used to express the various conditions.

6. Example of a Scliedule, filled up from Buttercup.

1. TOU may now begin to examine and describe 1. any flowers which may be within reach. And, in order that your work may be of value, I give at page 62 a form or schedule employed (under a very slightly different form) by the late Professor Henslow, both in his university and village-school teaching, the purpose of which is to compel attention to those points which are of the first importance (because most constant) in the structure of flowers. A supply of these schedules should be kept on hand for daily use.

Most of the terms made use of in filling up the schedules you have already acquired. It may be well, however, to look over the following list, which embraces all that need be used at present in describing the flower in the columns of the schedule, and if any have been forgotten, to turu back to them, by referring to the index. 
2. The column headed No. (number) is to be filled with the real number of parts, whether free or coherent, in each of the four series of organs (calyx, corolla, stamens, and pistil) which compose the flower. Thus, in Buttercup, there are five free sepals; and in Deadnettle and Primrose five coherent sepals. This number must therefore be entered opposite to sepals, under the No. column, and so on. These numbers, or a 0 opposite to an organ, necessarily indicate Suppression, when such occur's. Thus, in Deadnettle, with five sepals and five petals, there are but four stamens, one being suppressed, as we infer from the general constancy with which the parts, in each series of the flower in plants generally, correspond in number, or are multiples. We often find, however, more direct evidence in the presence of a rudiment of the suppressed organ.

3. The column headed Cohesion is to be filled up with those terms which express or involve cohesion of parts, or the absence of cohesion. 'Thus, were Buttercup being described, polysepalous would be entered in this column, opposite to calyx; the calyx being polysepalous from the absence of cohesion between the sepals. Deadnettle and Primrose, on the other hand, would be described in the same place as gamosepalous, the gamosepalous condition arising from cohesion of the sepals.

4. The last column, headed Adhesion, is for terms which, in like manner, express or involve adhesion of parts, or the absence of adhesion. Thus, in the caso of the three plants just referred to, inferior would be entered in this column opposite to calyx, the calyx being inferior because there is no adhesion between it and the ovary. 
Were Parsnip being described, the term superior would be entered in the same place, as in this plant the limb of the calyx becomes superior from the adhesion of its tube to the ovary.

5. The terms employed in filling uf schedules are :-

Of the CALYX (cohesion or its absence), polysepalous, gamosepalous; (adhesion or its absence) inferior, superior.

Of the corolla (cohesion or absence of same), polypetalous, gamopetalous (regular, irregular).

Of the stamens (cohesion or its absence). As it is important to note the number of stamens, and not simply to write polyandrous when the stamens are free, whatever their number may be, (as you write polysepalous and polypetalous of calyx or corolla when their parts are separate), write, before the termination -androus, the Greek numeral prefix denoting the number of free stamens, thus

If $1 . \quad 2 . \quad 3 . \quad 4 . \quad 5 . \quad 6.4$.

mon- di- tri- tetr- pent- hex- hept-androus 8. 9. 10. more than 10 .

oct- enne- dec- poly-androus.

If the stamens cohere by their filaments, they are mon- di- or poly-adelphous; if by their anthers, they are syngenesious.

(Adhesion or its absence) hypogynous, perigynous, epigynons, epipetalous, gynandrous.

Of the PISTIL (cohesion or its absence) apocarpous, syncarpous; (adhesion or its absence) superior, inferior. To denote the number of carpels constituting the Pistil, whether they be free or coherent (if the latter the number being inferred from the divisions of the style or stigma), the same Greek numerals as are employed to 
indicate the number of stamens are prefixed to the termination-carpellary. 'Thus monocarpellary signifies with one style or stigma, polycarpellary with many styles, cr stigmas, or distinct carpels. I have omitted these termis in the schedules of the Type-species in Part II. of this book, simply noting whether the pistil be apocarpous or syncarpous. The number of carpels is given in the No. column.

Of the PERIanth (cohesion or its absence) polyphyllous, gamophyllous (regular, irregular); (adhesion or its absence) inferior, súperior.

6 . The schedule here given, by way of example, is filled up from the Buttercap, with the characters of which you ought to be sufficiently familiar by this time.

\begin{tabular}{|c|c|c|c|}
\hline Organ. & No & rohesion. & Adhesion. \\
\hline $\begin{array}{l}\text { Calyx. } \\
\text { sepals. }\end{array}$ & 5 & Polysepalous. & Inferior. \\
\hline $\begin{array}{l}\text { Corolla. } \\
\text { petals. }\end{array}$ & 5 & $\begin{array}{r}\text { Polypetalous, } \\
\text { (regular). }\end{array}$ & Inferior. \\
\hline $\begin{array}{l}\text { Stamens. } \\
\text { filamests. } \\
\text { anthers. }\end{array}$ & $\infty$ & Poljandrous. & Hypogynous. \\
\hline $\begin{array}{l}\text { Pistil. } \\
\text { carpels. } \\
\text { ovary. }\end{array}$ & $\infty$ & Apocarpous. & Superior. \\
\hline $\begin{array}{l}\text { Perianth. } \\
\text { lecues. }\end{array}$ & 4 & $t$ & $t$ \\
\hline Class. & & Division. & Name. \\
\hline Dicotyledon. & $\mathrm{T}$ & ralamifloræ. & 3uttercup. \\
\hline
\end{tabular}

N.B. The sign $\infty$ denotes many. No entry is made opposite to perianth $(\dagger)$, because it is described as calyx and corolla in the case of Buttercup and other dichlamy. deous Dicotyledons. 


\section{CHAPTER VII.}

THE VAPIOUS ORGANS AND THEIR MODIFICATIONS.

1. Further examination of Plant-structure. The in. portance of frequent practice in order to acquire facility in the use of terms.

2. (Organs of Nutrition). The Root originates from? Tap-root; fibrous reot. Adventitious roots. Roots sometimes become thickened and tuberous.

3. The Stem originates from? Axillary and terminal buds. Direction assumed by stems. Rhizome; tubers; bulbs. The Stock. Remarkable modifications of stem-structures.

4. Leaves always lateral organs. Their arrangement upon the stem. Nodes and internodes.

5. Cotyledonary leaves are temporary. Scale-leaves. Duration of leaves.

6. Petiole and Blade. Vernation. Venation.

7. Outline of leaves. Simple and compound leaves.

8. Simple undivided leaves.

9. Simple divided leaves.

10. Compound leaves.

11. Apex and base. Mode of attachment to the stem. Margin. Surface.

12. Stipules. Stipulate and ex-stipulate.

13. Remarkable modifications of leaves. Phyllodes.

14. (Organs of Reproduction). Arrangement of flowero upon the stem. The principal kinds of infle. rescence.

15. The Bracts ; bracteate, ebracteate. Involucre.

16. Estivation of the calyx and corolla.

17. Parts of a petal. Of a gamopetalous corolla, and of a gamosepalous calyx.

18. The Stamens: peculiar conditions of which are noticed under the Natural Orders in Part II.

19. The Pistil. Homology of foliage-leaves and carpels. 
20 Canpellary theory. A review of various forms of pistil. The sutures of a carpel. The ovary and its cells.

21. Placentation.

22. Fruit and seed. Pericarp.

23. Suppression of cells of the ovary during maturation of the fruit. Changes in different layers of the pericarp. Fruit of Cherry, Apple, Orange, Gooseberry. Dry syncarpous fruits ; capsule, nut. Dehiscent and indehiscent fruits. Achenes of Buttercup and Strawberry. Blackberry. Mulberry. Fig compared with fruit of Rose. Enume. ration of principal kinds of fruit.

24. Number of seads in the fruit. Albuminous and ex-albuminous seeds.

1. T T E now proceed to examine some of the $\sqrt{ }$ different forms assumed by the Vegetative, or, as we previously termed them, the Nutritive, organs of plants-viz. the Root, Stem, and Leaves. Also, so far as previous chapters leave it reedful, the general character of the Reproductive organs, and especially the structure of the fruit.

In order to avoid ambiguity, we shall find it necessary to employ not only the substantive terms used by botanists to denote the several organs themselves, but also the more important of the adjective terms employed to denote special modifications of the same. The necessary terms are very simple, and easily learned, and, with moderate perseverance, facility in applying them may soon be acquired.

By carefully examining one plant every day, first filling up a schedule from the flower, and then writing out a description of all the organs in detail, with these lessons, or Dr. Lindley's pamphlet, "Descriptive Botany,"* before you, very

* Bradbury and Evans, $1 s$. 
considerable progress will be made in practical botany in the course of a single season.

In this and the following chapter, devoted to the structure of the various organs, whenever it has appeared desirable for the sake of illustration, I have named a common plant, which may be referred to; but it must always be borne in mind that the organs of plants-root, stem, leaf, and flower, are very prone to accidental variation, especially in minor particulars, so that occasionally I may be found epparently contradicting Nature. In such cases do not rest satisfied with reference to a single specimen: compare together a number of specimens whenever it can be done, and you will then find, I believe, the illustration confirmed. In explaining the terms used to denote the mere outline and form of organs, I have not generally referred to any species in illustration. I leave them to the learner to find out for himself.

2. The Root.--In the germinating Bean we find that the root is developed by the direct downward elongation of the radicle of the embryo. A root thus originating, forms what is termed a taproot. We have good examples of this primary root-axis in a large number of Dicotyledons, both trees and herbaceous plants, though in many, by arrest or by repeated branching, it loses, more or less, its character as a proper tap-root. In the Carrot and Beet, the tap-root thickening very much becomes fusiform in shape, and usually remains undivided, giving off delicate fibrils, which play an important part in the work of absorption. In Monocotyledons, owing to the origin of the root from root-buds which burst through the 
undeveloped radicle of the embryo, we never have a tap-root. In these plants the root generally consists of numerous independent fibres, branched or unbranched. It may be described simply as filvous. Pull up any grass, and you will find such a root.

In our first lesson we referred to a kind of Buttercup which forms creeping stems, giving off root-fibres at the nodes. This is a very frequent condition, and many herbaceous plants, both Dicotyledons and Monocotyledons, are principally multiplied, and the area which they occupy extended, by such creeping, root-producing stems. Roots originating in this way, and not by direct prolongation of the radicle of the embryo, are distinguished as adventitious. When adventitious roots are given off by climbing or erect stens, as in the Ivy and very many trees growing in hot, moist climates, they are termed terial.

Keeping the distinction $b$ tween true and adventitious roots in view, it will be clear from what we have said of the origin of the root-fibres in Monocotyledons, that they are always adventitious. Whether true or adventitions, however, the function of the root is the same.

The root frequently becomes much thickened in perennial and biennial herbaceous plants, serving as a reservoir of nourishment for the growth of the sprouts of the following season. When the branches or fibres of a root become thickened in this way, as for example in the Garden Dahlia, the root is said to be tuberous. Such tuberous roots much resemble certain forms of underground and similarly thickened stem, but differ from them in the absence of leaf-buds. 
Potatoes and Onions are called roots, but we shall presently show that this is a misnomer.

3. The Stem always originates in a bud; the primary stem of the plant from the bud of the embryo-the plumule. Branches in like manner originate in similar buds formed in the axils of leaves. Buds borne in the axils of leaves are axillary; those which terminate a stem or branch, and which, after a winter's rest in our climate, renew the shoot, are terminal. Some trees, as Palms, never or rarely develop any other than a terminal leafy bud, excepting when they form a flowering branch. The consequence is, that their stems remain unbranched.

We have already. referred to the distinction between woody and herbaceous stems. Besides erect or ascending annual flowering-stems, many herbaceous plants possess a stem which either creeps upon the surface of the ground, as in the Creeping Buttercup or the Strawberry, or which spreads wholly under the surface, giving off leafy and flowering shoots above and roots below, as Lily-of-the-valley, Wood Anemone, Sheep-sorrel, Sea Maram, and Couch Grass. The underground form of creeping stem is called a rhizome. Begimners are very liable to regard it as a root, and such is the common notion respecting it. The capacity of developing leaf-buds at regular intervals, and the presence of leaves in the very reduced form of minute scales, indicate its true stem character. In many plants, underground stem-branches become greatly thickened, like tuberous roots, and serve the same end in the economy of the plant. We have a good example in the Potato. The "eyes" of the Potato are F 2 
leaf-buds, and shoots develop from them when planted or placed in damp cellars. Such thickened portions of underground stem are called tubers. Somewhat similar is the very short and abruptly-thickened base of the erect stem of some herbaceous plants, as Crocus and Arum, distin. gruished under the name of corm. In the Onion and Hyacinth we have an analogous condition, disguised by very numerous, much thickened, scale-like leaves. If we peel off these scales successively, until they be all removed, we find a flattened, or conical, solid base remains, from the under side of which root-fibres are given off. This portion is the excessively shortened stem, from which the tall flowering peduncles arise. Stems of this kind, with the internodes suppressed and covered by thickened, scaly leaves, are called bulbs. Bulbs may be regarded as equally leaf and stem formations.

Perennial herbs, the flowering and leafy stems of which die down annually, often form a tufted mass, called a stock, either wholly or partially hidden under the surface of the ground. The. stock results from the persisting bases of the leafy stems. From the axils of the scale-liko leaves which these persisting stem-bases bear, the aunual shoots are thrown up each spring. The passage from plants with this form of perennial stock to those in which more of the exposed portion of the stem is perennial, as in bushes, shrubs, and trees, is quite gradual. Compare, in this respect, Monkshood, Cranesbill, Buttercup, Carnation, Fuchsia, Bramble, and Lavender.

The forms of stem and the direction which they assume above ground are exceedingly varied. 
Most of the modifications which they present are denoted by terms in ordinary use. Thus the stem may be erect, procumbent, or prostrate; cylindrical, angular, furrowed; and so on.

Branches sometimes assume very anomalous forms, and might be mistaken for distinct structures, as in the spines of the Hawthorn, and the tendrils of the Grape-vine and Virginian Creeper. All spines and tendrils, however, are not arrester. or specially modified branches; they are often leaves or leaf-appendages, as is the case with the spines of the Barberry and the tendrils of the Pea.

The internal structure of the stem may be more suitably described when we speak of cells and tissues.

4. Leaves.-We have already spoken of leaves as originating around the growing apex of the stem as minute, cellular projections. They are never terminal organs; neither are they, normally, capable of forming buds upon their surface. The arrangement of the foliage-leaves upon the stem, though at first sight it may appear accidental, is according to a generally constant law in the same kind of plant. Compare, with respect to leaf-arrangement, a young shout of Oak or Apple with one of the Strawberry-tree (Arbutus) or Monkshood. Try to find two leaves exactly or nearly in the same straight line, one above the other. In the Oak or the Apple the upper leaf will be removed from the lower by five internodes; in the Strawberry-tree or Aconite, by eight. When a single leaf is given off at each node, the leaves are said to be alternate ; if a pair of opposite loaves, they aro 
described as opposite; if three or more in a whorl, as verticillate.

The general arrangement of the leaves is materially affected by the extent to which the internodes of the stem develop. In Buttercup we find the lower leaves springing in a tuft from the short stock, owing to the non-development of the lower internodes; while the upper leaves are separated from each other by distinct, and often long, internodes. A parallel but more remarkable case we see in American Aloe (Agave) and Adam's Needle (Yucca), and, on a small scale, in the Lettuce and Dandelion, in which plants a succession of (really alternate) leaves are given off from a very short stem or stock, the internodes of which are not perceptibly developed. This is continued until the approach of the flowering season, when the stem suddenly begins to lengthen out, and the leaves either cease altogether for a long interval, as in Daisy and Dandelion, or gradually decrease in size to mere scales, as in American Aloe. In our deciduous trees, the nodes from which foliage-leaves are given off are developed at tolerably uniform intervals, but in Pine, Larch, and Cedar an anomalous condition occurs. In these trees there are two kinds of leaf-one a small, membranous, brown scale-leaf; the other, a green, needie-like leaf. The needle-like leaves are arranged in. tufts of 2,3 , or 5 in Pines, or in many-leaved clusters in Larch and Cedar, in consequence of the non-development of the internodes of the excessively short branches which bear them. That these tufts really arise from shortened 
branches, is obvious on examination, for they occupy the axils of the smaller scale-leares, and some of them occasionally develop their internodes, when, consequently, the needle-like leaves are borue singly upon the shoot, and are separated from each other by more or less marked internodes. In the Oak, the upper nodes of a year's shoot are usually more crowded than lower down. As a consequence the branches originating in the axils of these upper leaves by way of mutnal accommodation, spread apart at a wide angle, hence the characteristic ramification of the tree.

5. The cotyledons are the first leaves of the primary stem of the plant. They are usually, but not always, very short-lived, and shrivel up and die at an early stage. In some plants they never leave the testa of the seed, but remain underground, as in the Oak, Chestnut, and Pea. In the Beech, which is nearly allied to the two former, and the Bean, nearly allied to the lastnamed, they rise above the surface. The first leaves of branches ordinarily differ from those which follow, in being much smaller and often hard and scaly. These are the scale-leaves. They serve as protective organs to the delicate rudiments of the foliage leaves which they enclose. They may be easily found in many of our trees, as $\Lambda$ sh and Horse Chestnut. 'The last two are well adapted to show the gradual passage of the scale-leaves into ordinary foliage-leaves, convincingly showing that they are both modifications of one and the same organ. In Beech and Oak the stipules fulfil the same protective function.

Many trees develop each season terminal as 
well as axillary buds. As before pointed out, it is only by the development of the former that the original stem or its branches are prolonged. Some plants never renew their branches by annual terininal buds, as the Willow and the Elm. In the Oak, $\Lambda$ sh, and Pine, both terminal and axillary buds annually develop branches.

This variety of conditions in respect to the relations of terminal and axillary buds has much to do with the general aspect, or habit, of the tree. Note, for example, the contrast, in habit, between the Beech and the Elm. The leaves are two-rowed (distichous), the nodes often equally numerous, and the internodes about equidistant in length in both. But while in the Beech the axillary branchlets from the same branch of the previous year are neally equal in length, in the Elm they tend to become successively longer towards the apex, so that the contour of a two-year-old twig of Beech is comparatively parallel-sided, of Elm much broader, or obovate, above. The persistence of this general tendency year after year results in the contrast so conspicuous in winter between the two trees, between the arrow-like extremitiez of Beech, the rounded or shield-like terminal masses of Elm. In this connection our own British forest trees offer much interesting material for study, the normal relations being generally most clearly discemible in young and healthy cxamples.

Leaves vary in their duration. In our climate they usmally last but one season; at the close they separate from the stem, leaving a scar, or, if they remain attached, they decay gradually. In Evergreens, the leaves either persist until the expansion 
of those of the second year then falling off, in which case they are merely of annual duration, or they may remain attached two, three, or more years, in which case the same spray exhibits the successive generations, which are usually separated from each other by a space of twig bearing only reduced or scale-like leaves, answering to the winter-breaks between the successive periods of full leaf-development.

6. In the fully dereloped leaf we have already aistinguished petiole and blade. The mode in which the blade is folded while enclosed in the bud is spoken of as the vernation of the leaf.

The blade is divided into symmetrical halves by a midrib, which, continuous with the petiole, runs from the base of the blade to its apex. In the Begonias, some of which are grown in planthouses for the sake of their variegated leaves, and, less obviously, in the Common Lime or Lindentree and Elm, the sides of the leaf are more or less oblique or unequal.

The arrangement of the veins in the blade is made a special study by botanists who concern themselves with fossil plants, for the venation of leaves is almost the sole character left them of importance in fossil impressions, upon which to base comparisons with species still living.

7. In describing plants, the form or outline of the leaf must be noted, and an appropriate adjec. tive term selected to express it. As the forms assumed by leaves are infinitely varied, it necessarily follows that numerous terms must be used to denote them. The same terms apply, however, to any organs with plane surfaces, whether foliage 
or flower-leaves. The more important only we can note here.

In the first place, compare the leaf of an Appletree or Daisy with one from the Rose or Horse

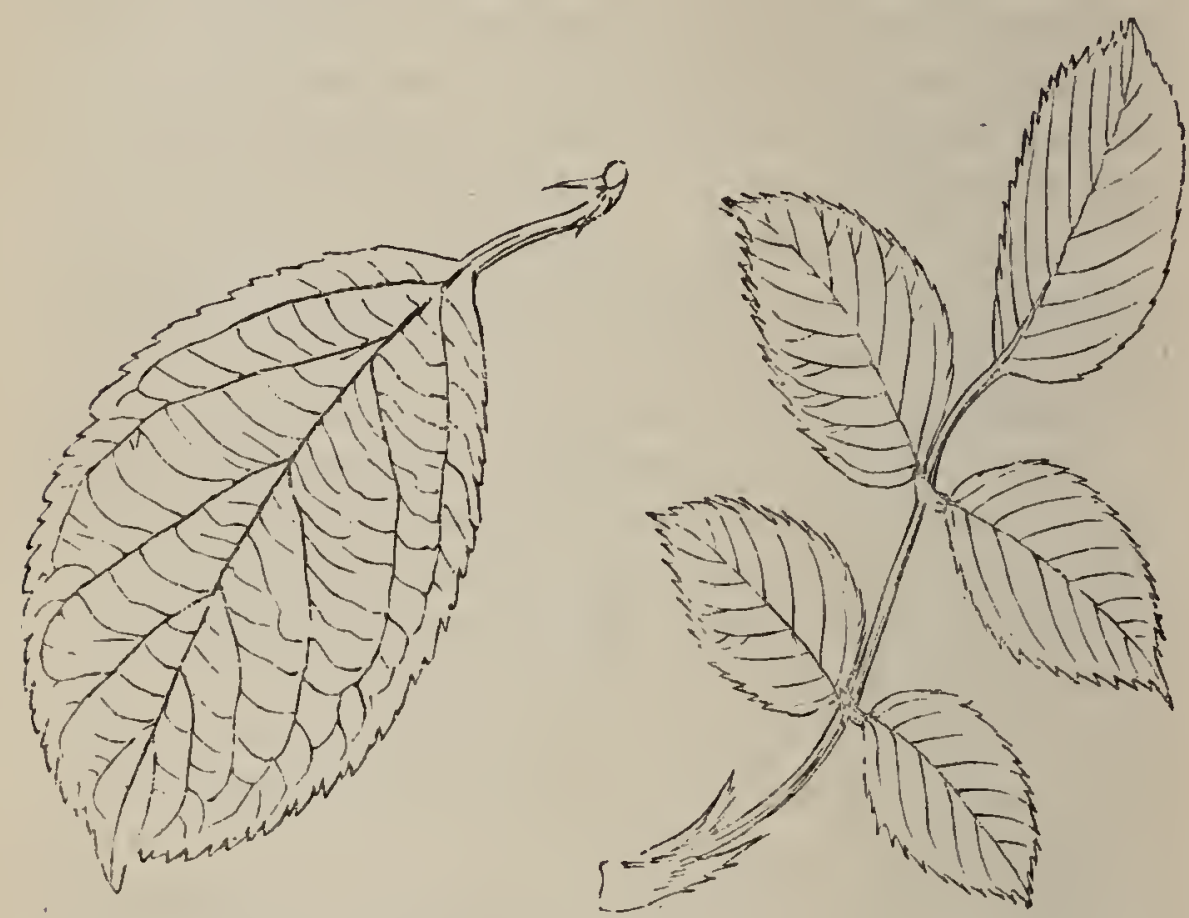

Fin. 38. Simple leaf of Apple.

Fra. 39. Compound (pinnate) leaf of Rose.

Chestnut. You observe that in the two former the leaf is in one piece; in the two latter the petiole bears several distinct pieces. These distinct pieces are called leaflets, and leaves which are thus divided into distinct leaflets are termed compound. Leaves, on the other hand, which are not divided into separate leaflets are termed simple. Simple leaves may be very deeply divided, as in Buttercup, but the divisions do not extend to the base of the blade, nor are they separately 
jointed to the petiole. The portions of a simple leaf thus divided are called the segments or lobes.

8. Simple undivided leaves.-It will be useful practice to try to find leaves which correspond to the various outlines figured below. It will constantly happen that the form of some leaves may be as correctly described by one term as by another; and again, some leaves vary so much on the same branch that they may be found to match $t$,ro, three, or more of the outline figures. In describing such leaves you must use the terms
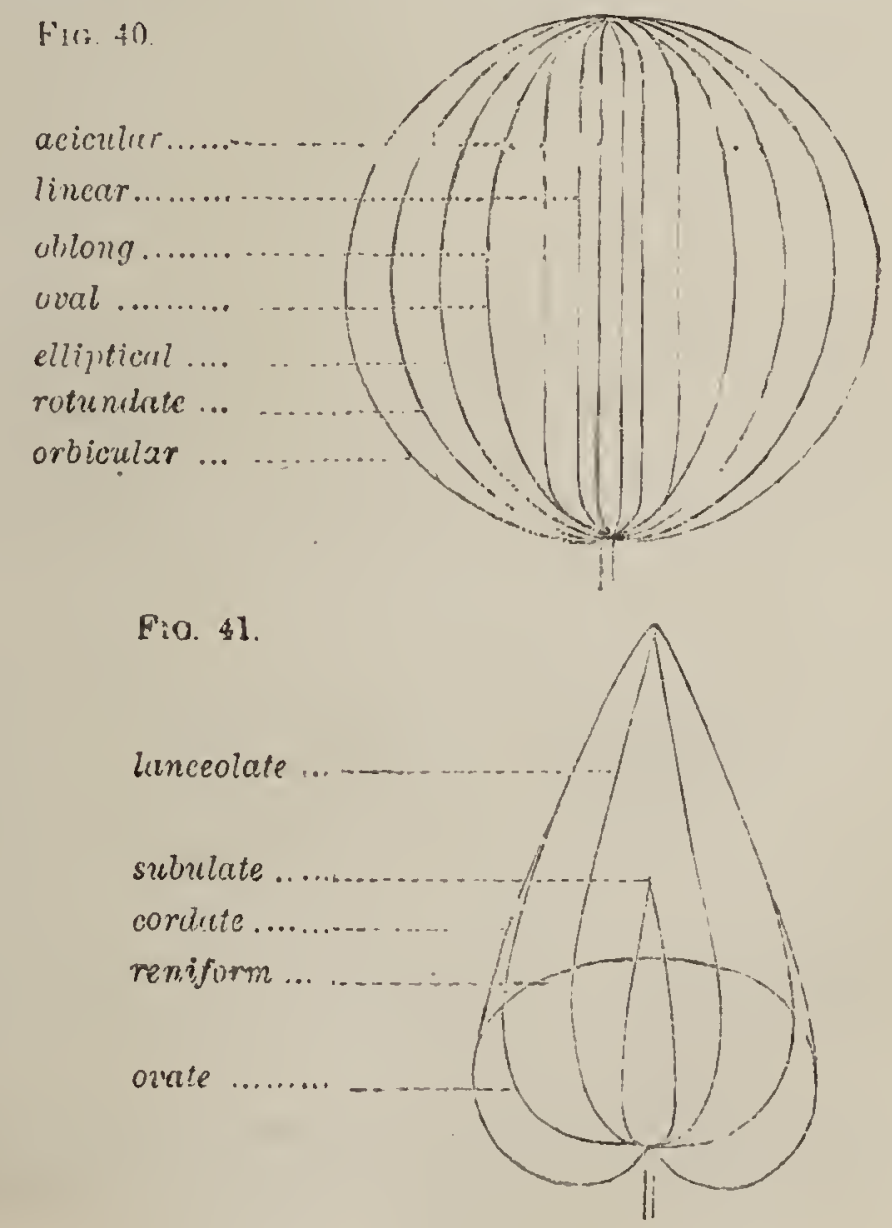


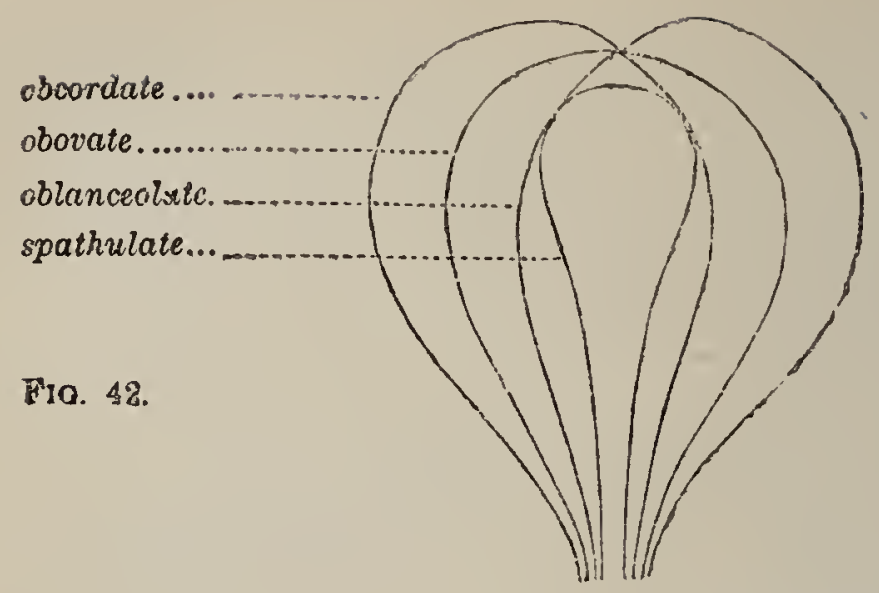

FIG 43.

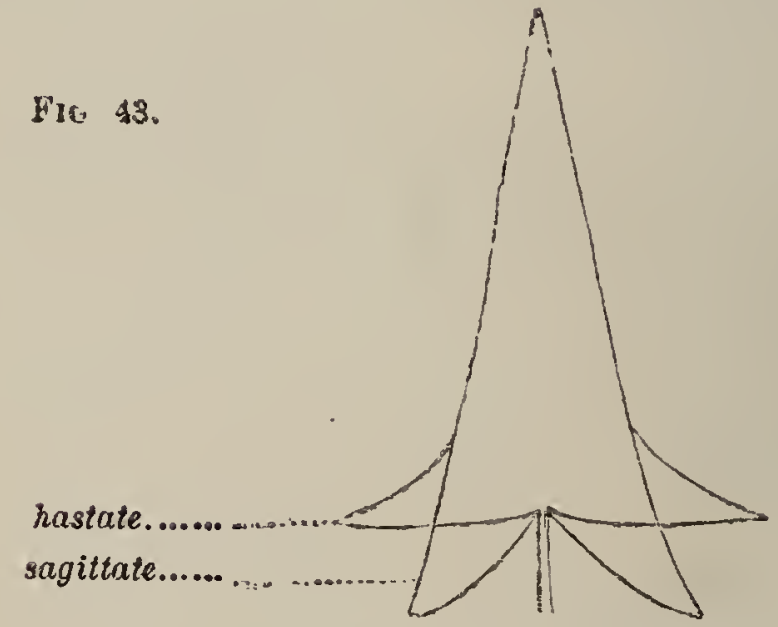

Figs. 40 to 43 . Outlines of simple leaves,

which denote the usual extremes of variation, as "leaves varying from lanceolate to ovate," or from "oblong to elliptical," \&c. The terms may also bo combined when needful, as oval-oblong, linearlanceolate.

9. Simple divided leaves.-We may class these under two series-viz. (1), those in which the segments radiate from the extremity of a petiole, as in Buttercup, and (2), those in which they are given off successively from a midrib, as in Dande. 
lion. The former are of the palmatifid, the latter of the pinnatifid type. If the segments be separated nearly to the petiole, the leaf is palmatipartite; if nearly to the midrib it is pinnatipartite. The termination -partite being substituted for -fid to denote deep division of the blade. There are many modifications of these principal types of form, distinguished by special terms, but with these it is not needful to burden the memory just at present.*

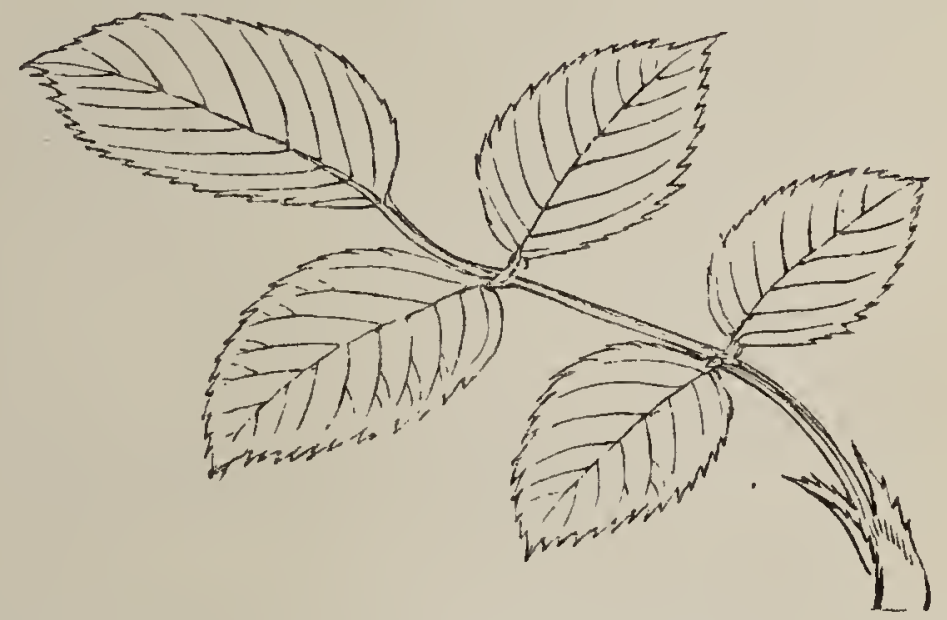

Fro. 44. Finnate leaf of Fose. A pair of adherent (adnate) stipules are shown at the base; one on each side.

10. Compound leaves we shall class as we have done the divided simple leaves, from which they differ in having the blade divided into leaflets, which are given off from the summit of the petiole, or from the midrib (common petiole), as the case may be. The leaffets separate from the petioie or midrib in the same way that the entire leaf separates from the stem, that is, without tearing.

* See Dr. Lindley's pamphlet, "Descriptive Botany." Iixplanations (with figures) are given of all the terms in common use. 
Sometimes it is very difficult to tell whether a leaf should be called simple or compound. Generally, however, it is plain enough. Many beginners fall into the mistake of calling leaflets leaves, but a little care will rarely fail to save any one from such a mistake. Compound leaves are either of the pinnate type, as Rose, or of the digitate type, as llorse Chestnut. The Rose leaf is unequally pinnate

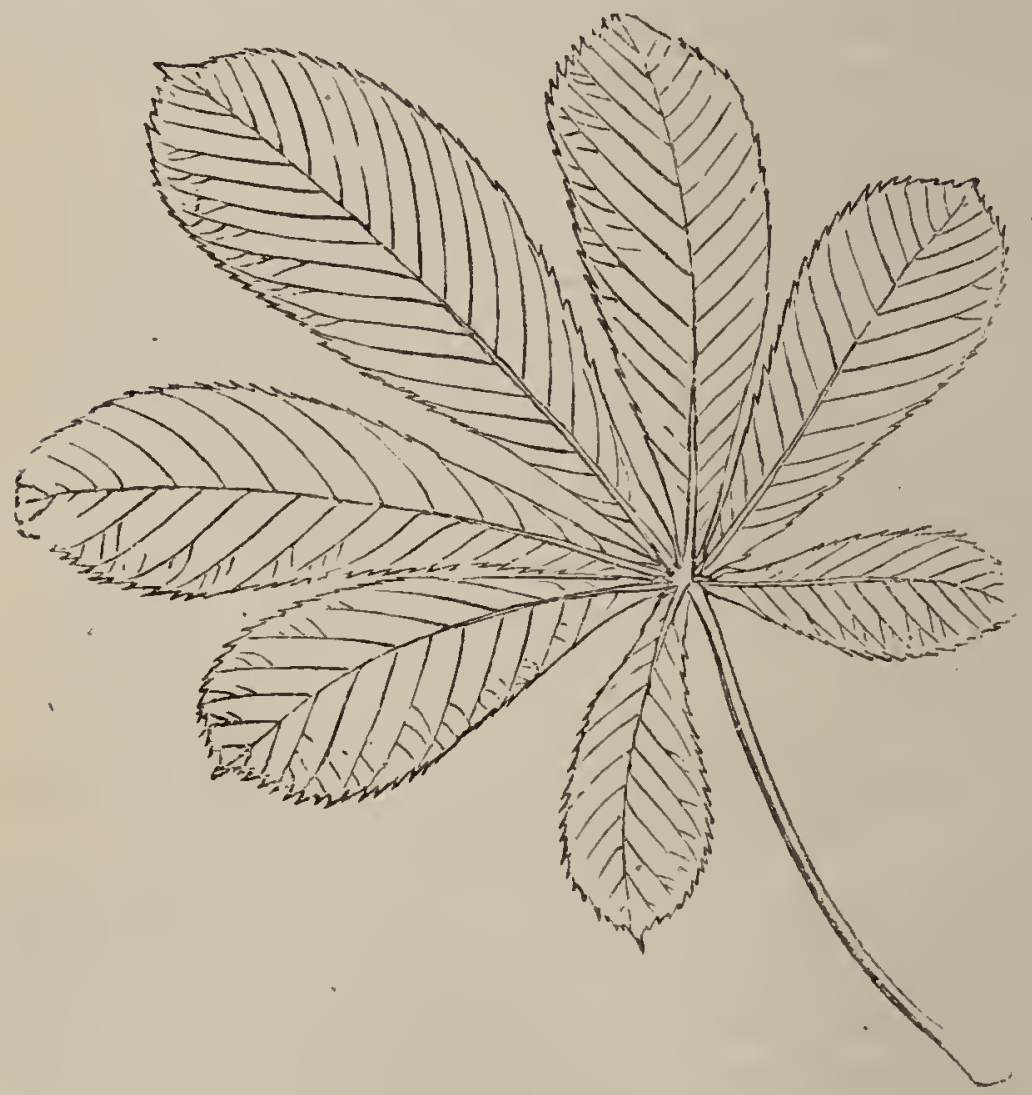

FiG. 45. Digitate itaf of Horse Cliestnut.

because there is an odd leaflet at the end of the common petiole. When the odd leaflet is absent the leaf is equally or abruptly pinnate. A leaf. becomes twice pinnate (bi-pinnate) when the common petiole, instead of bearing leaflets, bears 
secondary petioles upon which the leaflets are pinnately arranged.

When leaflets are arranged on the digitate plan, and are but 3 in number, they are called ternate, and the leaf is tri-foliolate, as in Clover and Strawberry ; if 5, quinate, the leaf being quinquefoliolate. The leaflets may be twice ternate (hiternate) if the petiole bears 3 secondary petioles, each of which bears 3 leaflets, and so on.

11. The point of a leaf or leaflet at which the midrib ends is called the apex. The point where it passes into the petiole, or, if the leaf be sessile, where it is joined to the stem, the base. The apex and base vary considerably in outline, and attention must be paid to both in describing the form of leaves. The apex, if sharp, is termed acute, if blunt or rounded, obtuse; if with a very shallow notch, emarginate; if the notch be deep, bifid-the leaf becoming bipartite if divided nearly to the base ; it is trifid or tripartite if there be three divisions. The base of the blade in cordate, sagittate, and hastate leaves we have already figured. If the base of a sessile leaf clasp the stem, it is termed amplexicaul. If the lobes at each side of the base of an amplexicaul leaf be united together on the side of the stem opposite to the midrib, so that the stem appears to pass through the blade, the leaf is perfoliate. If the bases of two opposite leaves be united on each side of the stem, as in Teazle, the leaves are said to be connate. Sometimes, in sessile leaves, the margins of the blade are continued down the sides of the stem, forming wings to it. Such leaves are decurrent. They are very common amongst Thistles. When the petiole joins the blade upon its under surface 
and not at the margin, as in Garden Nasturtium (Troposism), the leaf is said to be peltate.

The margin of the leaf varies, being sometimes perfectly continuous and not indented or toothed at all, when it is termed entire; it is serrate if with sharp teeth directed forward, like those of a saw; dentate if with sharp teeth directed outward; crenate if with rounded teeth.

The surface may be more or less hairy, or altogether without hairs, when it is termed

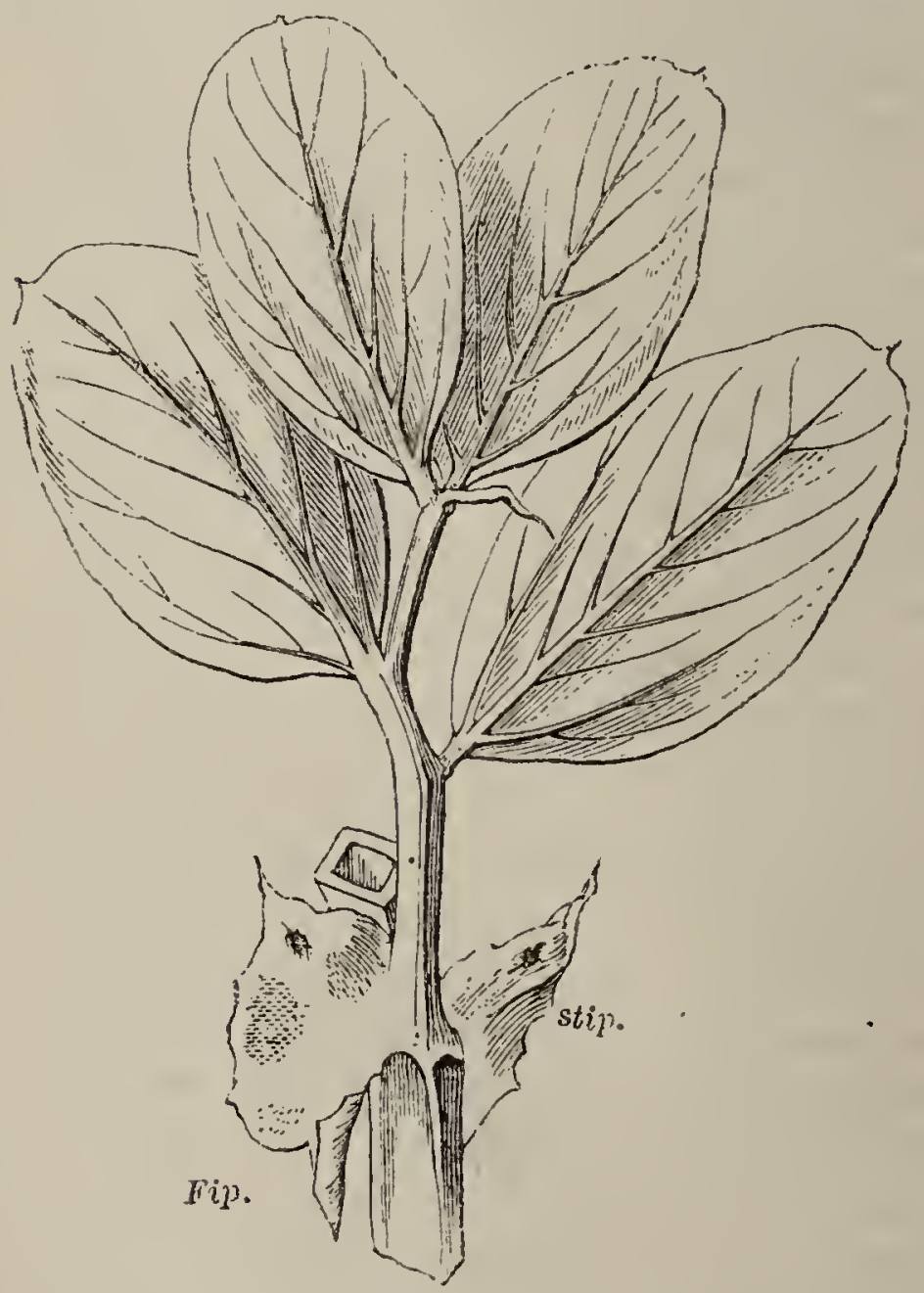

19. 46. Pinnate leaf of Bean. Stip. stipules, 
glabrous. Different terms are used to denote different kinds and degrees of hairiness, but it is not important to learn these at present.

12. Taking up again a specimen of the Pea or Bean, observe on each side of the base of the petiole a leafy organ somewhat resembling a leaflet. In the Pea these organs are very largelarger, indeed, than the leaflets. They are relatively very large also in the Garden Pansy. 'These are the stipules. Leares provided with stipules are called stipulate, and leaves destitute of them, as those of Wailflower, exstipulate. Like leaves and leaflets, the stipules vary in form, but they are usually small, and often fall away very early, as in the Oak and Beech.

13. Foliage-leaves are sometimes curiously modified, either to serve some special purpose, or by the absence of the blade, or the reduction of the leaf to a mere spine. Thus in the Pea we find the extremity of the common petiole and two or more of the lateral leaflets assume the form of tendrils, enabling the weak stem to lay hold of supports in climbing. Compare with the tendrils of the Pea those of the Grape-vine or Virginian Creeper, which we have described as branches modified for the same purpose (page 69).

In Barberry, the first leaves borne by the branches are reduced to sharp spines, from the axils of which spring tufts of ordinary foliageleaves, borne (as in Pine, Larch, and Cedar) upon branches with undeveloped internodes. Leaves tufted in this way are said to be fasciculate. In Whin or Furze, both the leaves (excepting those of the very youngr plant) and the branches are spinose. Stipules also are sometimes replaced by spines. 
When the blade of the leaf is absent, the petiole sometimes becomes flattened to such an extent as to look like an entire leaf, in order to replace the blade as an organ useful to the plant. But the flattcning is generally vertical, so that the apparent leaf is placed edgewise upon the stem, instead of

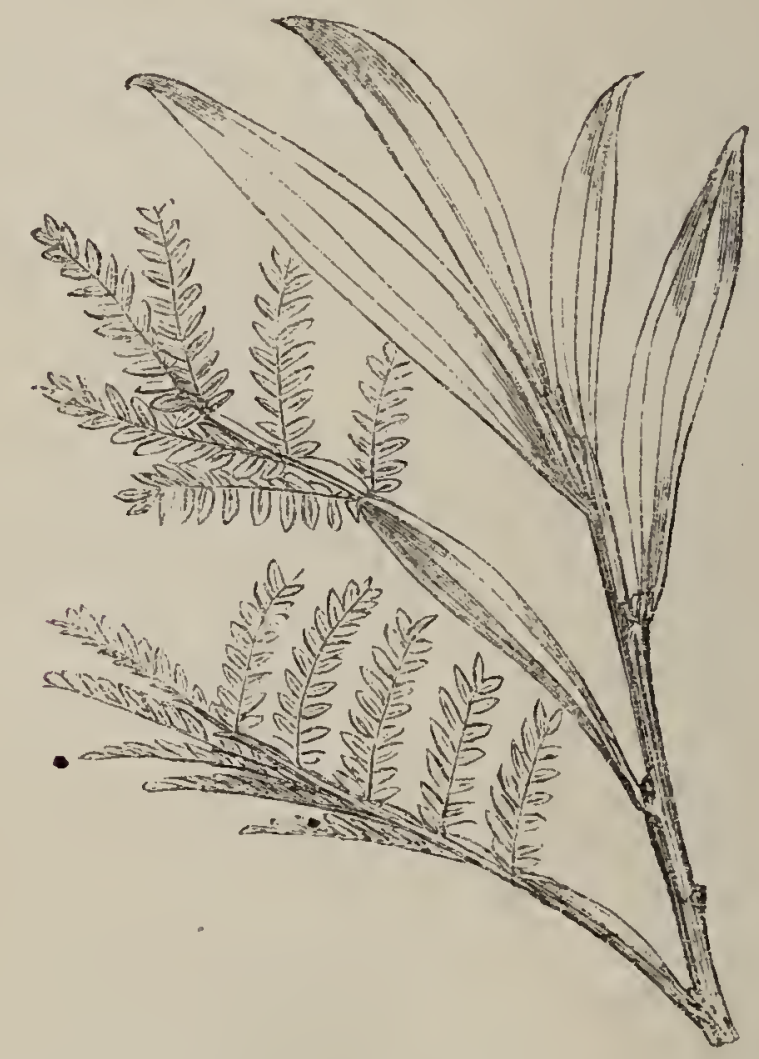

FIG. 47. Branch of Acreic melanoxylnn. The lower leaves with finnate hanina; the upper rerlucerl to petioles (phyllodes).

spaening horizontally. By this character these leaffike petioles may be generally recognised. They are caller phyllodes. Sometimes the true bade is partially developed at the extremity of the phyllode, thus putting its petiolar character beyond doubt. 
14. We cannot fail to have observed the varions ways in which the flowers are borne upon the stem. in gathering and comparing together the common plants which we have had occasion to use in the course of these lessons. It is convenient to speak of the Flowering System, or mode of arrangement; of the flowers of plants, as the INFLoREscence.

In the Tulip we find a solitary terminal flower, borne by a firm herbaceous peduncle, which appear's to spring directly from the root. (Such radical peduncles, whether they bear one flower, or many as in the Cowslip and Dandelion, are called scapes.)

In WallHower, the peduncle, instead of ending in a solitary flower, gives off successively a number of short-stalked (pedicellate) flowers in succession, until it exhausts itself and ceases to lengthen. Such an infloresence is termed a raceme.

Common Plantain, gathered to feed canary-birds, has a similar kind of infloresence, but the flowers are sessile. This difference distinguishes the spize from the raceme.

The corymb is a form of raceme in which the lower pedicels are much longer than the upper ones.

In Cow-parsnip and Carrot the flowers are borne upon pedicels springing apparently from one point. Such an arrangement of pedicellate flowers constitutes the umbel. But as you find each of the nmbels in these plants borne upon peduncles, which, like the pedicels, also spring from one point, the entire influrescence forms a compound umbel; the umbels of single fluwers being the partial umbels.

Oliserve the ring of small leares at the base of the pedicels in the Carrot, forming an invalucie, 
In compound umbels we frequently have both general and partial involucres, the former surrounding the compound umbel, the latter each partial umbel.

Suppose, now, all the flowers of a simple umbel to be sessile. We should have the same form of inflorescence as we find in the Daisy and Marigold, in which a number of florets are arranged upon a conical or flattened disk (the common receptacle), surrounded by an involucre. Such an inflorescence may be called a flower-head. The older botanists used to regard the flower-head as a kind of compound flower, enclosed in a common calyx, but we found in the Daisy that it was composed of a number of distinct flowers (florets), each with its own calyx and corolla. The ring of bract-leaves which surrounds the flower-head, answers to the ring surrounding the umbel, and is called by the same name-involucre. "Sunflower, Dandelion, Thistle and Groundsel, each lave this form of inflorescence.

In the Tulip the peduncle (scape) terminates in a solitary flower. In Wall Hower we found that the peduncle does not itself terminate in a flower, but gives off a succession of secondary branches (pedicels) each of which bears a flower. Now if we go back to the Buttercup we shall fird that the main or primary stem of the plant Jirectly terminates in a flower like that of Tulip, and if, as is usual, there is more than one flower upon the plant, the $2 \mathrm{~d}, 3 \mathrm{~d}, 4$ th flowers, and sc on, tcrurinate, respectively, as many successive independent branches, springing from the axils of the leaves. Such forms of infloresconce it which the peduncle, or axis, itself terminates in 
a fluwer are termed definite or cymose; whilo those inflorescences in which the principal axis never actually terminates in a fiower, but, as in Wallflower, gives off a succession of lateral pedisels, are termed indefinite. In the Chickweeds and Stitchworts we have the cymose or definite inflorescence well shown in their characteristic, forked cymes.

An inflorescence which branches irregularly, like that of Bramble, Horse Cheswut, and most Grasses, is called a panicle.

In describing the form of an inflorescence, when it does not exactly coincide with any of the principal types here defines., that which is nearest may, for the present, be applied to it in an adjective form, as spicate, racemose, paniculutelike a spike, a raceme, a panicle, and so on.

15. As we progress from below up varls in the examination of the various organs of the plant, we notice, in approaching the flowers, that the folinge-leaves usually decrease in size, as in the Buttercup, so that those next to the flower, or from the axils' of which the flowers spring, are often very narrow and sometimes scale-like. Such reduced leaves, bearing flowers in their axils, are distinguished as bracts, and flowers springing from the axils of bracts are bracteate. Orchis shows a very gradual passage from foliago. leaves to the bracts. In most plants the transition is much more abrupt. A ring or series of numerous bracts, enclosing flowers or pedicels, as in Dandelion and Cow-parsnip, we have called an involucre. In Wallflower the bracts are undeveloped, hence the flowers are ebracteate. 16. The organs of the flower, and their prm. 
cipal modifications, we ought now to be tolerably familiar with from schedule practice. 'There are, however, a few characters of importance which require further attention, applying particularly to the manner in which the parts of the calyx and corolla are folded while in bud (termed cest $i$ vation), to the form of the corolla, and the structure of the pistil.

In the bud, the sepals and petals (or the lobes of a gamosepalous calyx, or of a gamopetalous corolla) may be folded with their margins either more or less overlapping, or simply in contact without overlapping. In the former case, the astivation is imbricate, as in the corolla of Buttercup; in the latter valvate, as in the calyx of Clematis. Sometimes the calyx may be valvate and the corolla imbricate, as in Mallow.

17. The petals of a polypetalous corolla, if narrowed to the base like those of the Wallflower or l'ink, are clawed, the narrow part, bcing the claw, the expanded part the lamina. In a gamopetalous corolla, or gamosepalous calyx, the lower united portion is called the tube; the free rivisions, which indicate the number of parts cohering, the limb; the divisions of the limb being spoken of simply as teeth if small, or lobes if larger. The more important forms of the corolla are noticed in Part II. under the groups of plants which are respectively characterised by peculiar modifications of it.

18. The more important of the characters afforded by the stamens, due to varying conditions, as to coliesion, adhesion, and suppression, have been already, directly or indirectly, referred to. Some other peculiar modifications which they 
assume, either in form or in the mode of dehiscence of their anthers, are pointed out in Part II. as occasion arises.

19. The Pismil.-Whon in our first chapter we spoke of all the organs borne by the stem as leaves of some kind, you were not in so favourable a position as, from subsequent experience, you must now be, to appreciate the broad sense in which the word leaf was employed. I repeat, all the organs borne by the stem and its branches are modifications of one leaf-type. By this statement you are not to understand that a petal, or a stamen or a carpel, is a modified foliage-leaf, any more than that a foliage-leaf is any one of these organs modified; but they are all alike modifications of one common leaf-type which has only an ideal existence. Thus the leaf may be an organ either for the purpose of nutrition, or of reproduction, or it may be merely a protective organ; but whatever function it is designed tn fulfil-in other words; whatever special organ it becomes-it is modified appropriately to the function which it has to perform. Thus we havo the nutritive leaves, broad, green expansions, exposing the fluids of the plant to the influence of light; the protective leaves, hard and scalelike, as the scale-leaves of leaf-buds, or moro delicate, and often showy and coloured, as the enveloping leaves of the flower.

The essential reproductive leaves invariably assume one of two forms, either that of the staminal leaf, with the blacle (the anther) thickened and its tissue partially transformed into pollen, or that of the carpellary leaf, which is hollow, bearing a seed-bud or seed-buds (ovuleg) 
upon its margin inside, and terminating abuve in a stigma.

That this is the correct view to take of the nature of the leafy organs of a plant, we have incontestable external evidence to prove. And this evidence is principally of two kinds. Either we find one form of leaf passing by insensible gradations into another, as foliage-leaves into sepals, sepals into petals, petals into stamens-or we find some of the leaf-organs, especially those of reproduction, under certain conditions, assuming the character of other organs. Thus stamens, in many plants, have a strong tendency to lose their character as staminal-leaves and to assume that of petals, as you may find if you compare a Baclielor's Button with a wild Buttercup, or a double with a single Rose. There is, indeed, a Rose in which all the organs of the flower, excepting the sepals, so far depart from their normal character as to become small foliage-leaves, all coloured green, and firm in texture. In the epring-flowering Double Cherry not only are the stamens rearly all represented by petals, but the carpel (often two carpels) is represented by a green leaf.

The chief difficulty in the way of accepting the notion of the essential oneness and homology of all the leaf-organs of a plant rests principally in the wide dissimilarity existing, in the usual condition of things, between the leaves of the stem and the stamens or carpels, especially the latter. But the acceptance and thorough appreciation of this view you will find furnishes an invaluable key to the comprehension of all the various modifications which the pistil and its parts, tho 
carpels, undergo ; and it is especially with reference to these that we shall, at present, concern ourselves.

20. Take a pistil of the simplest possible structure,- - the pistil of the Pea or Bean, for example.

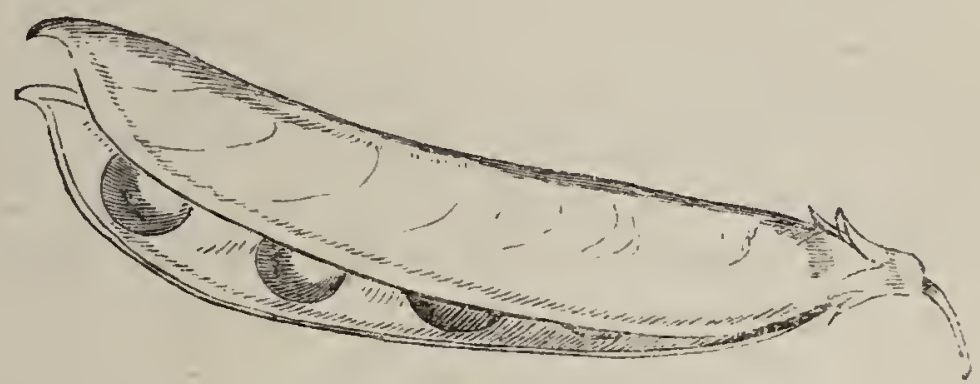

Fio. 48. Pod (legume) of Pea, partially laid open to show the attachment of the seeds to the ventral suture.

You have here an apocarpous pistil, consisting of a single carpel. Buttercup also has an apocarpous pistil, consisting, however, not of a single carpel, but of numerous carpels.

A comparison of any one of the carpels of Buttercup with the pistil of the Pea will afford

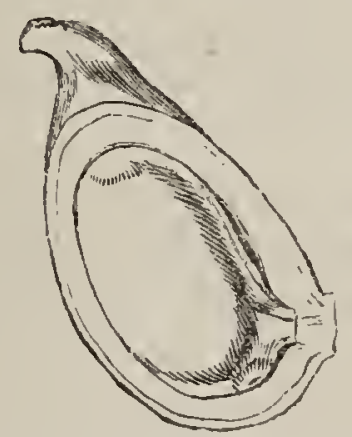

Fra. 49. Longitudinal section of a fruit-carpel of Buttercup, showing the remains of the oblique stigma.

satisfactory evidence that in the latter you have but a solitary carpel. In Buttercup you observe 
that the stigmas are all oblique to the carpels which bear them, and that they all radiate, as it were, from the centre of the flower. A like obliquity may be noticed in the Pea and Bean, the single carpel which these possess being the only one developed of a whorl of five. Sometimes one or more of the carpels suppressed in the Pea and Bean are developed in other species which are allied to them in general structure.

But Larkspur, Monkshood, or Columbine, furnish good connecting links between the Butter-

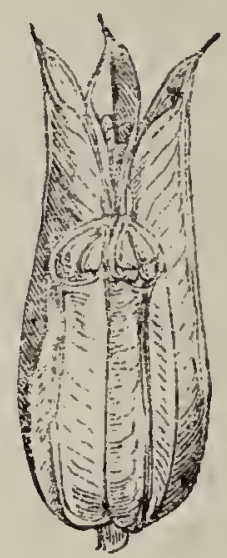

Vıc. 50. Fruit-carpels (follicles) of Columbine. The front ones cut across to show the attachment of the seeds to the ventral sutures.

cup and the Pea; for in these plants you find the carpels larger than in Buttercup, but fewer in number, varying from one to five, and standing in a whorl around the centre of the flower. Wach carpel of the pistil of either of these three plants answers to the pistil, consisting of one carpel, of the Pea and Bean. In all of these plants the pistil is apocarpous ; the carpels, however, differ in number, as well as in the number of ovules which they contain, and in their modo 
of opening when ripe (deliscence) to allow the seeds to escape.

Observe that in Larkspur, Monkshood, and Columbine, the ovules and seeds are borne upon the inner angle of the carpels. The same in Pea and Bean; and the inner angle of the carpels coincides with the axis of the flower.

Now ovules are, as a general rule, marginal buds, (the nature and relation of which, to ordinary leafluds, is not yet well understood), that is, they are borne upon the margins of carpellary leaves; so we may conclude that the inner angle of each carpel, upon which the seeds are arranged, answers ts the line of union of its infolded edges. This line is called the ventral suture.

To take the Pea again as the simplest case: if you split it carefully open up. the edge bearing the seeds, you will find, when laid open, that half of the seeds are on one edge, half on the other; each margin being alternately seed-bearing. Up the middle of the opened carpel you have a strong line or nerve (the outer angle when the carpel was closed), which is, simply, the midrib of the carpellary leaf, answering to the midrib which we find in foliage-leaves. This line is called the dorsal suture.

The apex of the carpel is continued into the short style, and terminates in the stigma, which withers before the Pea is ripe. Each of the carpels in the other plants which we have just examined presents the same features as the Pea. The Buttercup differs only in the small size of the carpels, each adapted to contain one small seed.

Suppose, now, the 5 carpels of the pistil of Columhine, instead of being free from each other, 
had been developed cohering to each other by their inner faces. The consequence would lave been that we should have had a syncarpois pistil with a 5-celled ovary. And syncarpons pistils with 5 cells, or more than 5 cells (as Orange), or fewer than 5 (as Tulip), occur on every hand, and are nearly always explicable in this way; that is, by the cohesion of as many carpels as there are cells in the syncarpous ovary. It follows from this explanation of the structure of a syncarpous ovary that each of the divisions, called dissepiments, by which syncarpous ovaries

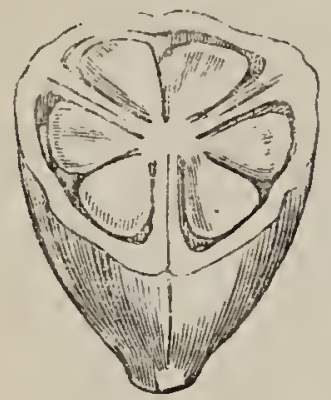

FI0. 51. Transwerse scetion of the s-cellen ovary of Tulip, showing axile placentition.

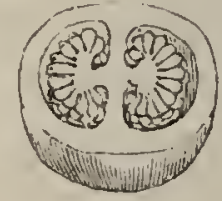

Fı. 5\%. Transverse section of the z-celled ovary of Forglove, showing axile placentation.

are separated into distinct cells, must be double. They must each necessarily consist of the two infolded and cohering sides of adjacent carpels. And so wo often find that when syncarpous pistils are ripe, their carpels separate from each other, each dissepiment splitting into two plates.

21. From the circumstance that the ovules develop upon the margins of carpels, it must follow that when two or more carpels cohere, and their margins are infolded so as to meet in 
the centre of the pistil, the ovules must also bo attached in the centre or axis. Their attachment, or placentation, as it is termed, is axile. You find this well shown in 'Tulip, where there are three carpels; Foxglove, where thero are two; and Orange, where there are many cohering.

But in many syncarpous pistils, although the carpels cohere, their margins are not infolded to such a degree as to reach the centre and become united there into an ovule-bearing axis. When such is the case, the placentation is described as parietal. We find all grades of development of these dissepiments, from the Violet and Pansy, with parietal placentation (the carpels not being infolded at all, and the ovules arranged in lines upon the inside of the one-celled ovary), to the Tulip, in which the carpels cohere to the centre, and the placentation is consequently axile. The pistil of Poppy is intermediate; the margins of the numerous united carpels which compose it projecting Fic.53. Transverse secinto the cavity of the ovary without quite reaching to the centre. The placentation of

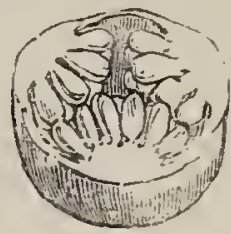
this plant is exceptional, the ovules being spread over the sides of the partial dissepiments, instead of being confined to their inner edges.

In Pinks and Stitchworts the placentation is axile, but the dissepiments are lost before the ovary is fully grown, so that the ovules are collected in a head in the centre of a 1-celled ovary. Such placentation is termed free central. 
The same kind of placentation is found in Primrose and Cowslip, but in these plants there is no trace of dissepiments.

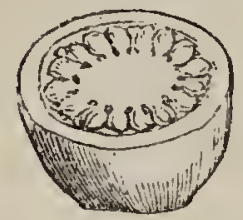

Fic 54. T'lansverse section of 1-celled ovary of Garden Pink, shnwing free central placentation.

In Pea, Columbine, and other apocarpous pistils, tho carpels of which contain several ovules, inserted upon the ventral suture, the placentation may be described as sutural. The sutural placentation of apocarpous pistils is, of course, essentially the same as the axilo placentation of syncarpous pistils.

22. The structure of the FRUIT deserves careful attention, especially that there is scarcely any part of the plant more liable to be misunderstood. We must learn from what part, or parts, of the flower the fruit results, and how to distinguish fruit from seed; for some common fruits aro constantly misnamed seeds, and sometimes seeds are mistaken for fruits.

Seeds are almost invariably contained in a seed-vessel called the pericarp, and the pericarp may consist either of the ripened ovary only, or if the ovary be inferior, of the calyx-tube combined with the ovary.

23. In the case of Buttercup, we have already learned that the fruit consists of as many distinct carpels as there were carpels in the pistil of the flower. Each carpel contains one ovulu in flower, and one seed in fruit. The pistil of Buttercup wo called apocarpous, and the same term applies to the fruit. 'In like manner we may apply tho term syncarpous to all fruits which result from syncarpous pistils. 
Now the changes which take place during the ripening of the fruit are very simple indeed in Buttercup compared with those which take place in many other plants. We often find that an ovary with several cells in the flower is but one-celled in fruit, and that many ovnles present in the flower are sometimes sacrificed during the perfecting of a single seed. Take an Acorn, or Beech-nut, for example. When ripe they contain but one cell and one seed, but if the ovary be cut across in June it will be found to be three-celled, with a pair of ovules in each cell. 'This suppression of parts during the ripening of the fruit is very common. It is, however, but one of the important changes to which it is subject.

Another change which greatly disguises the true nature of the fruit is the excessive enlargement of certain parts, or the alteration in texture and firmness of the layers of the pericarp.

Examine a ripe Cherry. You find it borne upon a peduncle. At the top of the peduncle there still remains a scar showing where the stamens were attached, and that the calyx was inferior. $A$ little dot on the top of the Cherry denotes the position of the style. It must follow, then, that the Cherry-fruit has developed from the ovary only. You cut into the pulp of the fruit, and find that it encloses a hard stone. Break the stone, and the seed will be found inside. The stone is a hardened inner layer of the pericarp, the pulp a succulent outer layer; both the stone and the pulp which surrounds it originate from the walls of the ovary. Stone-fruits, like the Cherry and Peach, are called drupes. Like the small fruit-carpels of Buttercup, thiey do not split 
open (dehisce) when ripe to let the seed escape, but simply fall to the ground, where the pericarp rots away and the seed begins to germinate.

Try now an Apple. Examine first the top of the peduncle, underneath the fruit. There is no scar to be found, as in the Cherry, but at the top of the Apple you find the distinct remains of the limb of the calyx, and sometimes even a few withered stamens. You thus know the fruit to be inferior. In a previous chapter (p. 31) we examined the ovary of the flower, and found that it was adnate to the calyx-tube. So ovary and calyx-tube together constitute the pericarp in the apple.

Next try an Orange. At the bottom of the fruit you find either the calyx still remaining, or its scar; the peduncle is not sent to Engrland attached to the fruit. On the top of the fruit is a little round scar; left by the style, which sonn withers after flowering, and usually breaks off. The Orange, therefore, is clearly a superior fruit, developed solely from the ovary of the flower. Cut it across, and you find it divided into a variable number of cells by membranous dissepiments, each cell answering to a carpel. In the pulp which fills the cells, and which is developed from the inside of the outer wall of the ovary, the seeds are embedded.

Try a Gooseberry. Like the Orange, it is a pulpy fruit, but from the distinct scaly tuft-- the remains of the calyx-limb-on the top of the fruit, and the absence of a scar at its base, it differs from it in being inferior. Cut across the middle you find it one-celled, and the cavity filled with juicy puln and numerous (indefinite) seeds, 
the latter being attached to the sides of the ovary (parietal). The fruit is a true berry; and the same name you may apply to any syncarpous fruit that is succulent, and that does not open (succulent fruits rarely do) to allow the seeds to fall out, such as Black and Red Currants and Grapes. Raspberries, Strawberries, and Mulberries we shall find are not true berries at all.

A syncarpous fruit that is dry when ripe, and which opens (dehisces) either by the pericarp splitting from the bottom to the top into valves, as in Horse Chestnut-or but partially from the top into teeth, as in Chickweeds and Stitchworts, or by little openings, called pores, such as are found in the ripe fruit of Poppy and Snapdragon-is called a capsule. And this name is applied to a great variety of fruits, differing much in size and mode of dehiscence, but all agreeing in being syncarpous, and when quite ripe, dry and dehiscent.

Syncarpous fruits, on the other hand, which are dry and indehiscent, that is, which do not open, but liberate the seed by decay, as the fruit of the Hazel, you may simply call nuts.

In Buttercup a number of distinct carpels collectively form the fruit, which, consequently, we have called apocarpous. Each carpel is dry, one-seeded, and indehiscent. Such fruit-carpels are called achenes.

We have an example of the achene in the apocarpous fruit of the Strawberry, which you must compare with that of Buttercup. If the strawberry be ripe, you find it to consist of a rounded pulpy mass, surrounded at its base by the persistent calyx. Scattered all over the succulent 
head are numerous very small bodies, conmmonly called the seeds. We do not find seeds growing exposed in this way, but enclosed in pericarps, and if we carefully examine the seed-like bodies we shall find they are fruit-carpels, because they each bear the remains or scar of the style (which is attached on the side of the ovary in the straw. berry); and if we cut one of them open we shall find it consists of pericarp and enclosed seed. They are indehiscent, and therefore wholly agree with the achenes of Buttercup.

What, then, is the pulpy mass which bears the achenes? There will be no difficulty in

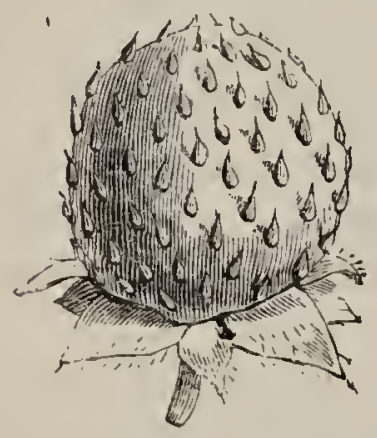

ElG. 50̄ Eruit of Sirawberry, showing persistent calyx, and enlarged succulent receptacle bearing numerous achencs. ascertaining what it is if you can gethalf-a-dozen specimens in as many different stages between flower and fruit. With these you can trace the gradual enlargement of that part of the receptacle of the flower which bears the carpels until it attains its full size in the ripe strawberry. It is therefore, strictly speaking, no part of the fruit. We shall now understand how the fruit of the Strawberry differs from the true berry.

But the fruit of Blackberry must be compared with it. Here, again, is an apocarpous fruit, consisting of a number of succulent little drupes (called drupels), arranged upon a slightly enlarged receptacle, each drupel answering to an achene of buttercup or strawberry. Thus Blackberries differ from Strawberries in having their carpels succulent instead of the receptacle. 
'The Raspberry is almost identical with the Blackberry, which we now find, like the Strawberry, has nothing to do with the true berry.

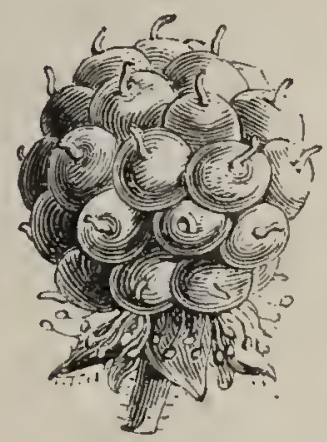

F10. 56. Fruit of Blackberry

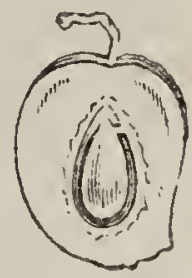

F19. 57. Single fruit-carpel (drupel) of same, containiug one pendulous seed.

With regard to the mulberry, the fruit of the Mulberry-tree. You have here the produce not of a single flower, but of a short, dense spike of pistillate flowers, each flower consisting of a perianth of four leaves in two pairs, enclosing the pistil, which is superior, and crowned by a bifid stigma. Now, as the pistil ripens and the seeds mature, the persistent perianth-leaves become very succulent and juicy; and it is to these organs, thus altered in texture, that the mulberry owes such value as it possesses as an eatable fiuit. The mulberry, therefore, differs from all the so-called berries which we have examined as yet, in the circumstance, that it results not from a single flower, but from a number of flowers. On this ground it may be distinguished

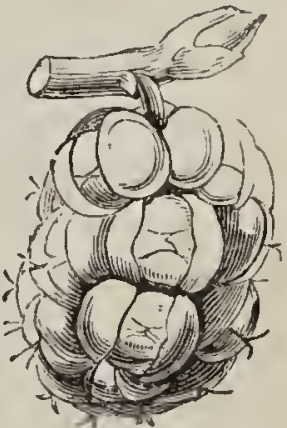

FIg. 58. Collective fruit of Mulberry. as a collective fruit. All fruits which result 
from more flowers than one are collective fruits. We have examples in the cones of the Pine, Larch, and Cedar, in the Pine-apple, and the fruit of the Fig. A fig you can easily get for examination. If cut across, it appears to be filled with small dry seeds enclosed in a succulent pericarp. But such is not really the case. The

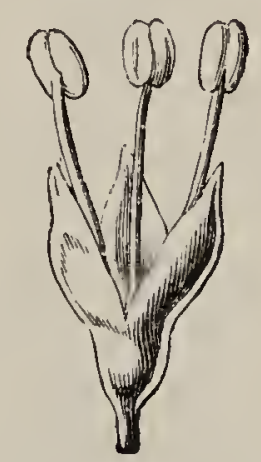

Fig. 59. Staminate flower of the Fig.

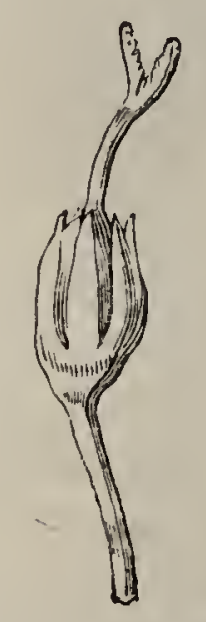

FIG. 60. Pistilate flower of same.

cuts show the staminate and pistillate flowers of the Fig. In order to observe them you must gather a fig while young and green. You will then find that the inside of the fig is thickly crowded, not with ovules, but with these minute, monochlamydeous flowers; the pistillate flowers usually occupying the lower and greater part of the cavity. It follows, therefore, that the pulpy portion, which forms the mass of the fig, is a common receptacle, deeply concave and nearly closed at the top, bearing numerous flowers upon its surface. If you have the opportunity, compare with the fig the "hip" of a Rose. Although rather similar at first sight, they are essentially 
different. The fruit of the Rose results from a single flower, the "calyx-tube" of which becomes more or less succulent, and usually red in autumn.

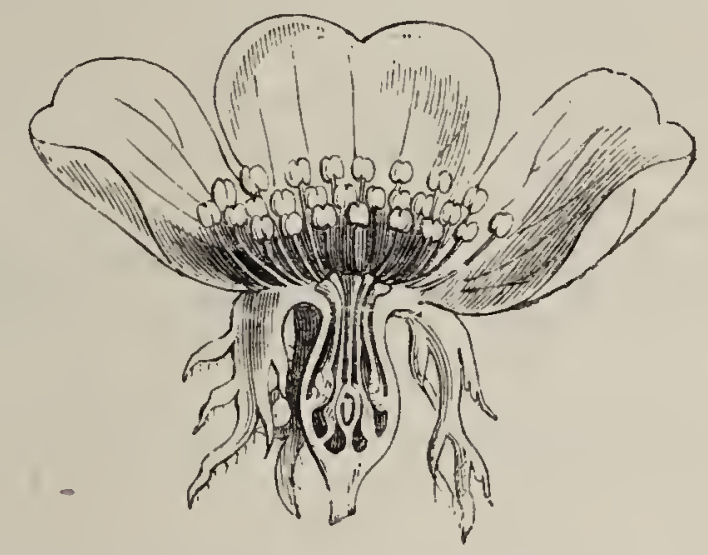

Fig. 81. Vertical seetion of flower of Rose, showing the carpels enclosed in a deeply concave receptacle.

Inside are the separate, dry achenes, which must not be mistaken for seeds. The fruit of the Rose is analogous to that of the Strawberry, chiefly differing in the receptacle, which is concave instead of convex.

Besides the forms of fruit which we have enumerated, there are a few others so distinct in character as to merit special names and descriptions; but, as these are confined to certain groups of plants, they may be suitably noticed when we come to speak of the general character of the respective groups in Part II.

The prevalent forms of fruit, the structure of which should be thoroughly understood, are as follow :-

SIMPLE FRUITs (resulting from a single flower). Achene, apocarpous, dry, indehiscent, usually one-seeded (Buttercup, Rose, Strawberry). 
Nut, properly syncarpous and indehiscent, the pericarp usually hard and bony (Hazel).

Drupe, usually apocarpous, succulent, indehiscent and one-seeded, with the inner layer of the pericarp stony (Cherry, Almond, Peach).

Berry, syncarpous, succulent, indehiscent, several- or many-seeded (Gooseberry, Currant, Grape).

Capsule, syncarpous, dry, dehiscent (Primrose, Chickweed, Tulip, Orchis, Violet, Horse Chestnut).

Collective fruirs (resulting from two or more lowers).

24. The structure of the SEED we have already carefully examined in the Buttercup, Bean, and Wheat. In examining plants, it will be sufficient at present to note whether the seeds are solitary, definite, or indefinite in the ovary if it be apocarpous, or in each cell of the ovary, if syncarpous. 'Thus the seeds are solitary in Buttercup, Parsnip, Deadnettle, and Marigold; definite (few and constant in number) in the Apple ; and indefinite (numerous or variable) in Primrose. Note, also, whether the seeds are exalbuminous, that is, containing embryo only, as in Pea, Wallflower, Apple, and Marigold; or albuminous, containing albumen along with the embryo, as in Parsnip, Buttercup, Tulip, and Wheat. 


\section{CHAP'TER VIIr.}

TII MINUTE STRUCTURE AND VITAL PROCESSES

OF PIAN'TS.

1. The minute parts of which plants are composed.

2. The cells (of Phubarb).

3. The vessels (of Rhubarb and Oak). Their modifica. tions. They originate from cells.

4. Tissues for comparison with those of Rhubarb.

5. Active cells contain fluid contents.

6. Cell-wall and cell-contents.

7. The former temary, the latter quaternary.

8. Division and growth of cells.

9. Temporary reserves. Starch-granules. Oil. Sugar.

10. Colouring matter of leaves.

11. Crystals in cells.

12. Long and short cells. Fibro-vascular system of plants.

13. Comparison of the arrangement and mode of in. crease of fibro-vascular bundles in Monocotyledons and Dicotyledons. The cambium-cells. Exogenous and endogenous stems.

14. Woody Dicotyledons further examined. Pitl ; wood; medullary rays; bark.

15. Circulation of fluids through the cells. Diffusion.

16. The epidermis and its structure. Stomates. Intercellular spaces.

1. $\mathrm{N}$ our second chapter we inquired very 1 briefly into the functions of the nutritive organs. Now that we have had the opportunity of comparing the corresponding organs of many plants, and of forming some tolerable idea of the extent to which the same organ may vary, in external character, in different 
plants, it may be worth while to examine more closely than it was at first expedient, into their mode of working. In order to understand this, you must first acquire a correct knowledge of the minute composition of the various organs. Now, their minute composition is, generally speaking so simple, that you need find no diffi. culty in comprehending it; but the parts of which I have to speak-which build up the leaves, and stem, and root-are so very minute, that unless you make use of a microscope that will magnify, say, 40 to 80 diameters, you will be unable satisfactorily to see the parts which compose these organs. In order to meet this difficulty, in case you cannot get a sight of the objects themselves, which is always best, refer . to the cuts, which correctly represent all that is necessary.

2. Take first, if you please, a very little morsel of Rhubarb; - out of a tart or jar of stewed or preserved Rhubarb will do very well. It is better that it should be cooked, because then it is soft enough to be torn or dissected out with needles. If you have no Rhubarb at hand, a bit, as large as a small pea, of any soft, herbaceous plant will do. Rhubarb is particularly wellsuited, because the parts which I wish you to examine are not quite so minute in it as they are in plants generally.

We will suppose that you have taken a very small morsel of boiled Rhubarb. You observe that it is quite soft and pulpy, and that a few fibrous strings appear to be mixed up through it. Take a little of the pulp on the end of a needle and put it upon a slip of glass, adding 
a drop of water. If you have a thin glass cover, put it over the drop, gently letting one side rest first on the slip as you put it down, so as to push out the air-bubbles, which are apt to get entangled, and which look like round balls with black sides when magnified. When you look at the Rhubarb under the microscope, you are pretty sure to find a number of bodies resembling those represented in the cut. If you do not find them, try another morsel until you succeed. These bodies are called cells. They are hollow sacs, each filled with fluid. Now, of cells more or less like these, differing principally in size, in relative length and breadth, and in the thickness of their sides, every part of every plant is composed. the organs are built up of these minute cells.

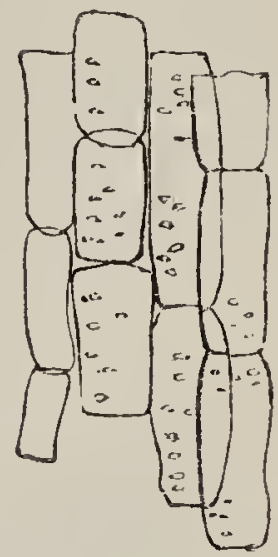

3. But take now a very small bit of one of the fibrous strings of the boiled Rhubarb. Place

Fig. 62. Cellular tissue from the petiole of Rhubarb, magnified.

it in a drop of water, and, with a couple of needles, one in each hand, separate it into what seem, to the naked eye, to be its constituent fibres, just as you would separate a morsel of string into its finest threads. When you have got it dissected out, put a cover on as before, and examine it under the microscope. You will probably find here, besides numerous cells of various lengths, some long tuhes, with their sides (walls) curiously marked with delicate fibres, usually arranged in a spiral direction, twisting round and round inside the tube-the coils some- 
times very close, sometimes loose; or you may find the fibre in the form of separate rings in the inside of the tubes. These tubes are called vessels. They originate in this way. A number of cells, such as we saw before, standing one over the other in a row, have the partitions which separate them more or less completely removed, so that the row of cells becomes open all through. We have then a true vessel. Vessels are almost invariably marked either by a spiral, netted, dotted, or ring-like thickening upon the inside of their walls. In Rhubarb this thickening usually takes the form of a spiral fibre, but if you boil a bit of oak-wood, half the size of a pea, in a

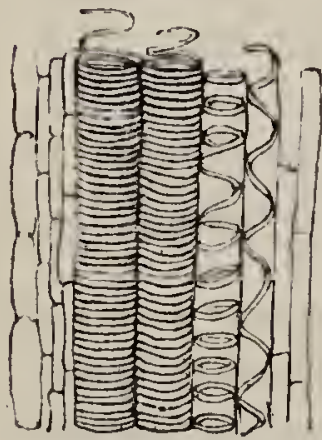

Fia. u3. Vessels from the petiole of Rhubari, magnified.

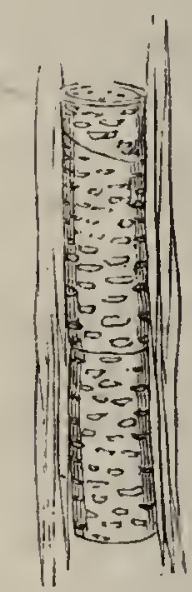

Fra. 64. Thin section of Oakwood, magnified, showing a dotted vessel, betweon long wood-cells.

few drops of nitric acid for a few seconds, it will become white and soft, and after washing it in water two or three times to remove the dangerous acid, you may dissect it in the same way as you did the Phubarb. You will find the vessels 
which it contains more or less like those in the cut. The larger vessels of oak-wood differ from those of Rhubarb merely in the thickening on the inside of the vessel being more uniformly spread over the wall, omitting only minute spots, which look like holes or pores through the wall of the vessel. Such dotted vessels are very common in wood, and may be easily observed by making very thin slices of the wood lengthwise with a sharp razor.

Plants, then, are built up of cells, or of cells and vessels; the latter originating from cells.

4. Compare with the structure of Rhubarb and oak-wood that of the following tissues, selected as well suited to show different modifications of cells and vessels, because easily obtained and requiring little preparation.

Pulp of ripe Strawberry. Large, thin-walled cells.

Pith of a young branch of any tree, especially Elder. The cells are often closely packed, and consequently polygonal.

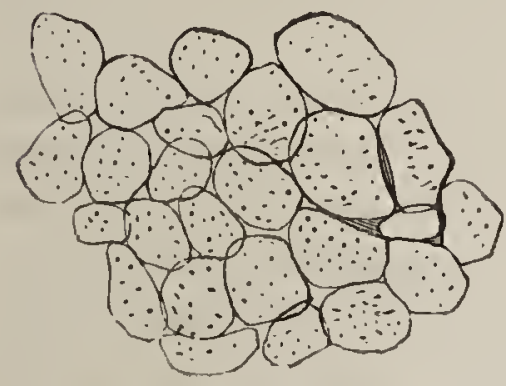

Fig. 65. Cellular tissue from the pith of the Elder, magnified.

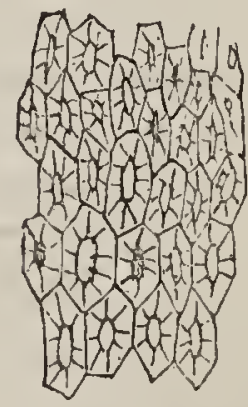

Fig. 66. Cellular tissue, with the walls of the cells much thiekened, as in the stone of stone-fruits ; magnified.

Piece of the stone of a stone-fruit, or shell of 
a nut, as Walnut, ground excessively thin, by rubbing it with the finger upon a hone. The cells have very thick sides, so thick that sometimes the cavity is almost obliterated. The "pores" are lengthened out into long "canals" which radiate from the cavity of each cell.

Potato. Apple. Thin-walled cells.

Young shoots of Brake Fern (boiled to a pulp). Large vessels, marked with cross bars.

Pine-wood (thin slices, both lengthwise and across the "grain"). Long, thick-walled, tapering cells, without any vessels. The sides of the cells are marked with minute disks.

Thin petals, and petals doubled back to show the projecting cells on the folded edge.

Pollen. The grains are usually oval or roundish, and generally separate. Compare the pollen of Mallow, Cucumber, Fuchsia, Lily, Deadnettle.

5. We have spoken of cells as containing fluid. So they do, as long as they continue to take part in the work of the plant. But in old trunks of trees, the cells forming the older wood sometimes become so very thick-walled that they cease to do any work, and, indeed, may be said to have no room left to do it in.

6. Take some active, sufficiently transparent cells, such as you find upon the margin of a young leaf of Nettle, and removing a morsel of the leaf without injuring the hairs upon it, place it in a drop of water upon a glass slide under the microscope. You observe that each hair is simply a cell of the surface of the leaf which has grown out into the air. Now, if you add some fluid that will kill the cell, such as a drop of spirits of wine, you will find, after 
allowing it time to act, that the contents of the cell separate from the wall of the cell and collapse, lying as a loose sac or irregular mass in the middle. We may, therefore, distinguish cell-contents from cell-wall. And the distinction is an important one, since all the real work of the plant is done by the cell-contents; the cell-walls forming merely the framework of the workshops in which all the secret and wonderful operations of plants are carried on.

It is this comparative isolation of an infinite number of vital fragments that constitutes the chief difference between the vegetable and animal series of the organized world.

7. In our second chapter we spoke of the elements carbon, oxygen, hydrogen, and nitrogen, as existing in plants in a series of peculiar combinations, some of which chemists are not yet able to imitate in their laboratories. These combinations we called ternary and quateruary, from their consisting respectively of three or of four elementary or simple substances. The cell-wall consists of carbon, oxygen, and hydrogen, forming a ternary compound (cellulose). The essential part of the cell-contents consists of the same elements combined with nitrogen, forming a quaternary compound. Wherever we have growth going forward, there we have this quaternary compound in activity.

8. The way in which growth in plants takes place is simply this. The contents of the cells of the growing part divide into two, and between the halved contents there forms a thin iayer of the ternary cell-wall, which divides each cell into two distinct cells. The new cells then increase 
in size until they become as large as their parent cell, when they each divide again, and the process is repeated. The process is modified according as the cells are to lengthen or to remain short.

9. In observing the tissue of a Potato, referred to above as well adapted to show thin-walled, closely-packed cells, you may notice that the cells which are not cut into (and thus emptied) in making a very thin slice are filled with very minute, ohlong granules. If the slice be too thick, the granules are so numerous that they entirely conceal the delicate cell-walls. These granules, which are stored up in nearly all the cells of the Potato, are called starch granules. To compare with potato-starch, you may take the smallest possible pinch of dry arrowroot and dust it upon your slide, and you will find that the granules of which arrowroot consists, though they differ a little in form, are, in other respects, like those of potato-starch. You may make quite sure of it, if you add a small drop of weak tincture of iodine, when they ought at once to become a deep violet; for iodine forms with starch a violet-coloured compound.

Similar granules to those of the Potato, allowing for differences in size and form, you may find in nearly all flowering plants. 'They are especially abundant in thickened roots, in underground stems, and in seeds. In these organs the starch is stored away as a temporary reserve; to be made use of after a winter's rest, or (in the seed) at the time of germination. The granules then dissolve, and may be said to be eaten by the quaternary cell-contents. Starch is identical in chemical composition with the ternary 
substance of which the cell-wall is formed. It differs from it in being a temporary deposit instead of a permanent one.

Another form in which temporary reserves are stored up in the cells, we find in the globules of oil abundant in some colls, especially of certain seeds and fruits. Hence we find the principal source of our vegetable oils in the fruits of different plants, as Rape-seed (embryo), Olive (pulp of drupe), Cocoa-nut (albumen), \&c.

Sugar is another food-deposit of plants, differing from starch in being soluble in the watery cell-sap which fills the full-grown cells. It would appear to be usually an intermediate condition of the plant's ternary food, either preceding the formation or immediately following the solution of starch. It abounds in the cell-sap of the stem of the Sugar-cane and in the root of the Beet.

10. There is another important cell-content of which we have not spoken. If you take any green part of a plant (and it will be best to take a morsel from some succulent leaf, or the thin leaf of a moss), and examine the cells under a powerful microscope, you will find that the entire cells are not coloured green, neither are the whole of the cell-contents, but that the colouring matter is limited to very minute granules lying in the colourless fluid contents. These are called the chlorophyll granules. The development of the green colour of these granules is determined by the action of light, as may be proved by growing plants in total darkness, when they become blanched. The granules are not wholly composed of colouring matter, for the green colour may bo easily removed by a little spirits of wine, leaving 
thegranules, which are of quaternary composition, almost unaltered.

11. Besides starch, oil, and chlorophyll, there may frequently be found minute crystals, either in the form of needles, or collected into nodules, lying in the cavity of cells. They are called raphides, and are, generally, of subordinate importance.

12. Besides the distinction which I have pointed out between cells and vessels, you may roughly group the different kinds of cells as ?ong or short. Long cells are usually thick-sided and often taper at each end, so that when a number of them are grown together, forming a tissue, we find such tissue to be generally firm and tough. Such cells, together with a few vessels, form the principal mass of wood, of petioles, and of the veins of leaves. These veins, which have nothing in common with the veins of animals, serve as a sort of framework for the support of the short cells, which occupy their interstices. The short cells of leaves are generally thin-walled, and during spring and autumn they are busily engaged in elaborating the food of the plant, by the aid of the sun's light and heat. The bundles of long, thick-walled cells, with the vessels which accompany them, forming the veins, we may speak of as the fibro-vascular system, and the short cells as the cellular system of the leaf. In the petiole the cellular system is much reduced, and the fibro-vascular system is contracted into narrow compass.

13. The arrangement of these systems, as they are termed, in the stem, differs considerably in the two great: Classes of flowering plants. 
Excepting in their single cotyledon and the behaviour of the radicle in germiration, Monoco. tyledons are not, at first, materially different from Dicotyledons; but when one or two seasons of growth are over, a marked difference in the mode of arrangement of their fibro-vascular bundles becomes apparent. And this difference essen. tially consists in the circumstance that in Monocotyledons the fibro-vascular bundles remain permanently isolated, and once completed in the stem do not receive any addition in thickness; while in Dicotyledons they become confluent, forming a continuous ring around the pith, and constantly increase in thickness during the successive working seasons of the tree by organically continuous additions to their outer side : so that in Monocotyledons the bundles are closed or definite; in Dicotyledons, continuous or indefinite.

But the nature of this difference you will appreciate better when you understand the composition or arrangement of the tissues forming these fibro-vascular bundles. Each bundle contains at first a layer of cells of extreme delicacy, which cells are capable of undergoing division and enlargement, and it is by means of this layer only that the bundle can increase in thickness. This layer of active cells is enclosed between two distinct systems: one system, on the

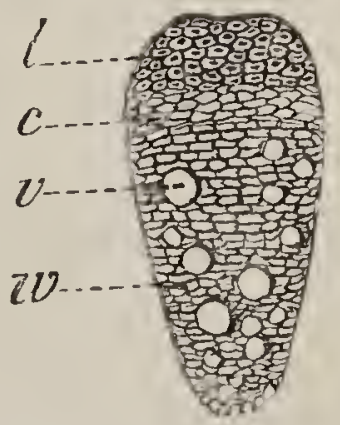

Fı. 67. Diagram repre. senting the arrangement of the tissues in a fibrovascular bundle; $l$ the liber, c cambium-layer, $w$ wood, $v$ w'de vessel of the wood. 
side towards the centre of the stem, consisting of long, thick-walled cells and vessels, forming the proper wond of the fibro-vascular bundle; and another (smaller) system on the side of the bundle towards the circumference of the stem, characterised by thick-walled, tapering cells, forming the liber system.

The figure (67) represents a fibro-vascular bundle cut across, showing at $c$ the layer of delicate

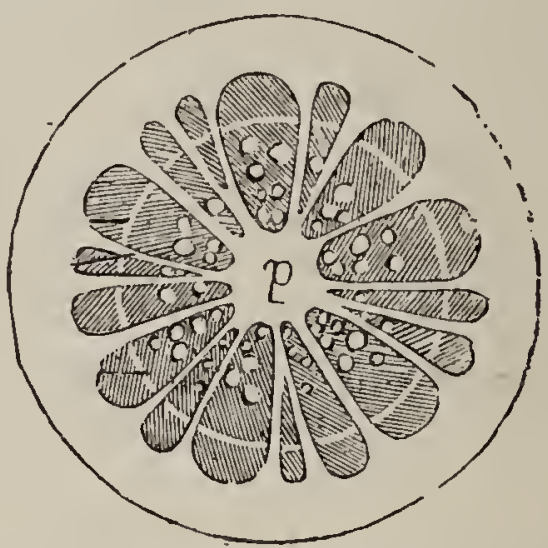

Fig.68. Diagram showing the arrangement of the fibro-vascular bundles (each of them wedge-shaped in cross-section), in the stem of a young Dicotyledon. The pale circle passing through each bundle near its thicker end indicates the future cambiuin. cylinder. $p$ the pith.

cells, called the cambium-layer, the cells of which divide and give off new cells on each side-on the inner side wood-cells $(w)$ and vessels $(v)$, on the outer side fibrous liber-cells $(l)$. In Dicotyledous these bundles are arranged in the stem in such a manner, at a very early stage of its growth, that the cambium-cells of the bundles, which are side by side, coalesce and thus form one continuous cylinder of multiplying and enlarging cells. The consequence is, that in Dicotyledons all the wood is on the inside of this cambium-cylinder, and 
new wood is deposited on the outside of wood previuusly formed: all the liber, on the other hand, is on the outside of the cambium, and immediately within the bark - of which, indeed, the liber is regarded as forming an inner layer. Structure such as here described is precisely what we find in the stem of an Oak or any other of our native trees, which are said to be exogenous, from the circumstance that their wood increases by additions to its outside.

In Monocotyledons, on the other hand, the cambium-cells of the different fibro-vascular bundles

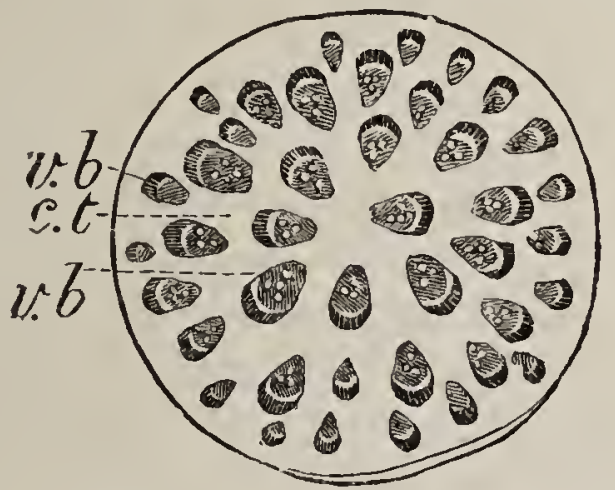

Fig. 69, Diagram showing the arraugentent of the fibro-vascular bundles in a cross-section of the steri of a Monocotyledon. $v b$ fibro-vascular bundles, $c t$ cellular tissue.

never coalesce so as to form a cambium-cylinder; consequently they do not form continuous rings of wood. The cambium-cells, therefore, soon cease their dividing and enlarging work, and the fibrovascular bundle is finished. We find, if we cut the solid stem of a Monocotyledon across, that the tibro-vascular bundles are irregularly scattered all through the cellular system of the stem. They are especially crowded towards the circumference, which consequently becomes much harder than 
the centre in woody Monocotyledons. From the mode of development of the fibro-vascular bundles, and the direction which they take in the stem, the trunk of woody Monocotyledons does not usually increase in diameter beyond a certain point, as we find in Palm-trees, which frequently have tall cylindrical stems as thick at the top as at the base. These peculiarities led the older botanists to call such stems endogenous, from a notion that the younger bundles were those in the centre of the stem, and that they pushed and compressed the older bundles towards the outside. The only woody Monocotyledon native in Britain is a shrub called Butcher's Broom. In hot countries they are numerous, though belonging to very few Families.

14. But the structure of woody Dicotyledons, with which, in our cool climate, we are most intimately concerned, requires further examination.

Take a cross-section of the stem of an Oak, several years old. You find in the centre the remains of the original cellular system of the stem, reduced to a very narrow cord, and distinguished as the pith. When young the pith served to contain and to convey nourishing fluids to the growing point; now it is dry and useless. Surrounding the pith is the wood, forming the great mass of the stem. A number of concentric rings are distinguishable in the wood, there being as many rings as years that the stem has existed, one ring to a year; so that by counting the rings you may ascertain the age of the stem. The appearance of rings, or annual eones, in the wood, arises simply from the wood formed in summer and autumn being denser. 
closer-grained, and with fewer vessels than that formed in spring.

With a little care you may notice that there are, as it were, narrow rays proceeding from the pith to the bark. These are actual plates of cellular tissue left between the fibro-vascular bundles, which look like narrow ravs when cut through transversely. They are called the medullary rays. They are usually very narrow, much narrower in most trees than in the Oak, the wood of which, when cut lengthwise in the direction of these rays, is marked by silvery patches of the cells of the rays, forming what is called the silver-grain, which painters imitate in painting wainscot.

It will be difficult to find the cambium-ring without using a lens, but it is immediately within the bark, which it connects with, while at the same time it separates it from, the wood.

The outer layers of bark are usually composed of short cells of corky texture, which serve to prevent the cambium-layer from drying up, by checking evaporation from the surface.

From the mode of increase in diameter of the woody axis of Dicotyledons indicated above (pp. i 14, 116), it must follow that unless the outer bark retains sufficient vitality to permit the formation of new cells, so as to actommodate itself to the increasing diameter of the wood which it encloses, it must necessarily become ruptured. And so we find in the majority of our trees that the bark becomes longitudinally fissured, as in Oak, Elm, and Willow. In healthy Beech, however, the bark retains sufficient vitality to permit dilatation pari nassu with the dilatation of the stem, and so retains at tolerably uniform surface. In Birch and Plane 
the bark separates in successive thin plates. In Scotch Fir both radial fissuring and concentric lamination occur. Here, again, we have opportunity for interesting observation in the field, in trying to ascertain what causes determine the weakest lines of the bark, and so bring about the mode of fissuring peculiar to each species, or group of species.

The inner or liber-layer of the bark of many plants and trees is made use of for cordage and in cloth-making. Hemp, flax, and Russia-matting, are all derived from this layer, which, in the plants affording these products, is very tough.

15. The questions now present themselvesThrough which of these cells, or systems of cells, in the stem, is the watery sap, absorbed by the roots, couveyed to the leaves? And when the sap has been exposed to the sun's influence in the leaves, how does it find its way through the plant? In other words, how do the sap and nutrient fluids circulate in the plant? But these questions, reasonable though they seem, it is impossible to answer satisfactorily in the present state of our knowledge.

It is not our business just now to concern ourselves with contested points, so we must be content with a very general and partial explanation. In the first place, we must recall the fact that the entire plant is built up of closed cells and vessels; consequently, solid substances, even in the minutest state of subdivision and suspension in water, cannot be admitted by healthy uninjured plants. Mistakes as to this point have arisen from using injured or wounded plants for experiment. Therefore only fluids, substances dissolved in fluids, and gases, can be absorbed by tho 
piat ; viz. fluids with solids or gases in solution by the roots, gases and vapour by the leaves.

The circulation or transference of these fluids and gases from cell to cell can only be by diffusion, a physical process, probably controlled in some way not yet understood, by its taking place in a living apparatus. This process of diffusion depends upon two conditions. First, we must have two fluids separated by a membrane of some kind which they can permeate. Second, these fluids must be of different chemical composition, or of different density. When these conditions exist, a current is set up through the membrane, which results in one of the fluids (the denser) increasing in bulk at the expense of the other. This increase is due to Diffusion. The affinity of the membrane itself for one of the fluids in preference to the other modifies the result. Now, these conditions obtain throughout all plants, excepting, of course, the old dead and dry portions of trunks, \&c. They are built up of closed cells, containing fluids of various density, and the walls of the cells are permeable. The consequence is, that there is a constant transmission of fluids going forward throughout their tissues. The direction of the current is mainly determined by the constant evaporation from the leaves, which necessarily tends to render their cell-contents denser, so that the water taken up by the surfacecells and hairs. of the root-fibrils is impelled upwards cell by cell, to restore the equilibrium, until it reaches the leaves and other tissues exposed to evaporation. The course which the ascending sap, as it is termed, takes has been usually supirosed to be through the cells forming the younger 
layers of wood, the ressels assisting when the current is rapid. This, however, is not absolutely determined. The elaborated sap (that is, the sap, after having undergone certain chemical changes, especially in the leaves, determined by the influence of the sun) is generally admitted to descend chiefly through the inner layers of bark. Indeed, a rude experiment may be regarded as strongly confirming this view. If you remove a ring of bark from the stem of a tree, or bind it very tightly round with a strong hoop, no wood will be formed below the ring or hoop. On the other hand, a considerahle thickening will take place iumediately above it.

From the absence of a system of vessels analogous to that of animais, and of a pumping-engine like the heart, the course taken by fluids in plants is comparatively very vague and ill-defined at best. I have here merely indicated its general course in the stems of Dicotyledons.

16. I have spoken of leaves as capable of absorbing gases, especially carbonic-acid gas, and, probably, also vapour, from the atmosphere.

If a leaf be examined carefully, it will be found covered with a thin skin or epidermis, which vely often (in fleshy leaves) may be torn off in filmy shreds. And a similar epidermis covers nearly all the green and coloured organs which are exposed to the air. If a piece of this epidermis, torn from a leaf with the thumb and a sharp penknife, be placed in a drop of water upon a glass slide, its structure may be easily made out under the microscope. Suppose a shred torn from the leaf of a Hyacinth. It will be found to consist of an excessively thin layer of flattened cells, closely fitting 
at their angles. Scattered at intervals over the enidermis are pairs of very small cells side by

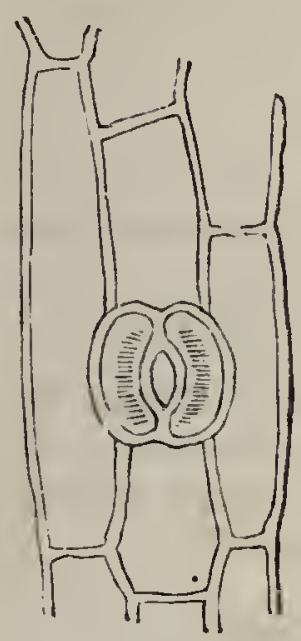

Fig. 70. Épidermis of Hyacinth, showing one open stomate. side, with their ends in contact, as shown in the cut. Each pair of cells forms a stomate. When the cells of the stomates are rendered turgid by the absorption of fluid, they separate more or less from each other, leaving a minute opening in the middle between them. When they are flaccid, the guard-cells remain closely applied, and the orifice is closed. Under ordinary conditions of the air as to moisture they are open; when it is either very dry or very moist, they are generally closed.

The stomates, therefore, serve to facilitate the absorption of gases, and probably of vapour, from the air. They do not, however, open into cells, but into spaces between the cells of the leaf, called intercellular spaces. These intercellular spaces are widest between the cells forming the lower layers of the leaf, and we find that stomates are generally much more abundant in the epidermis of the lower than of the upper surface of leaves. There are no stomates on roots, nor, usually, on surfaces under water. 


\section{PART II.}

\section{ClAASIFICATION OF PLANTS.}

1. Extension of the plan of examining Type-specimens to subordinate groups.

2. The specific and generic names of plants. Individuals. Species. Genera.

3. The Binomial method of naming plants. Diagnostic characters.

4. Arrangement of genera under superior groups. Subordination of characters.

5. Varieties.

6. Explanation of the Type-lessons. Necessity for a constant reference to specimens.

Page 129.

Examination of Typical species of the principal Natural Orders of British Flowering or Phaneroga. mic*Plants. Deviations from the respective Types and important struetural peculiarities are noticed. Economic applications of the species are referred to.

Page 292.

Flowerless or Cryptogamic Plants. Their principal Types.

Page 308.

How to dry specimens for the Herbarium.

Page 315 (Appendix.)

How to describe Plants.

1. T $\mathrm{N}$ preceding chapters we have endeavoured to illustrate the prevalent structure of Dicotyledons and Monocotyledons, by referring to a very limited number of common plants, which we made use of to illustrate different kinds 
of modification in the various organs, and especially in the parts of the flower.

Thus we made use of the Buttercup and others as examples of the Dichlamydeous Subclass, the Stinging Nettle of the Monochlamydeous Subclass, and the Willow of the Achlamydeous Subclass of Dicotyledons. And, further, we employed Buttercup, Pea, Bramble, Apple, and Parsnip as examples of the Polypetalous Division, and Marigold, Deadnettle, and Primrose of the Gamopetaluus Division of the Dichlamydeous Subclass, and so on for each of the principal divisions of Dicotyledons and Monocotyledons.

These illustrative examples we may regard as representative types. Each type embodies the characteristics of a large group, the members of which group, though they differ from each other in minor details, such as regularity or irregularity of the corolla, and sometimes in the number of stamens and of carpels, generally agree in characters which, from experience, we infer to be important, from their prevalence through a large number of plants. These important characters are principally based upon adhesion, cohesion, and suppression of the parts of the flower.

By extending this method, by selecting and carefully studying types representing the principal subordinate groups, called Natural Orders, of British Flowering Plants, we shall lay the sure basis of a thoroughly scientific acquaintance with them. The types which we presently proceed to select from each important Natural Order are not always the best suited to serve as representatives of such Order, because we shall be obliged to make use of plants of which speci- 
mens nay be easily obtained, and these do not always happen to be best adapted for the nurpose. Besides, in some Natural Orders the amount of variation in minor characters is so considerable that we shall find it needful to employ subtypes, the relation of which to their type we shall endeavour to make clear whenever we find it needful to employ them.

You must not be content with the examination of those plants only which are employed as types. You must try to refer to its type every flovering plant you meet with, and, in a short time, you cannot fail to recognise easily the Natural Orders to which most British plants belong. In the following pages you will observe that each plant is designated both by an English and by a scientific name. This is done partly that you may be familiarized with a plan of naming plants based upon definite principles, and partly that the memory may be stored (though we would not have it burdened) with at least the generic scientific names of our common native plants, which names are in use amongst botanists of all countries.

2. The scientific name of every plant consists of two words, a substantive and an adjective. The substantive is the name of the genus, as Brown or Jones may be the name of a family. 'The adjective indicates the species, as John, 'Thomas, or William indicates the individual niember of a family.

But species is a collective term, and the same specific name is applied to all the individuals which belong to the same species. All individual plants which resemble each other so nearly that it is consistent with experience to suppose that 
they may all have sprung from one parent stock are regarded as belonging to the same species. In other words, the differences between the individuals of the same species are generally not greater than we are accustomed to observe between the individual plants in a field of Turnips, or of Wheat, or in a bed of Pansies, sown with seed which we know to have been gathered originally from a single plant. All plants, therefore, which resemble each other thus nearly are referred to the same species, and the same specific adjective name is employed to designate them.

Then again, species which resemble each other in all important particulars of structure (though it is impossible to define the exact particulars, for to a great extent they are arbitrary and of convenience,) may be referred to the same genus, and the same generic substantive name is employed to designate them. Thus, we refer all the species of Buttercup to the genus Ranunculus, and of Rose to the genus Rosa. In this way we have genera (plural of genus) including often many species, sometimes several hundreds: we have sthers, again, which include few or but single species. In the latter case, we have species which are necessarily comparatively isolated in the characters of their flowers; more so, at least, than are the species of larger genera.

3. Recollect, then, that in the scientific name of a plant we always state both the name of the genus and that of the species to which it belongs. The generic name precedes. Thus, Ranunculus bulbosus, Ranunculus acris, and $R a$ nunculus repens are three distinct species of Buttercup familiar to botanists, and always ad- 
mitted as distinct, although their differences are so slight that the untrained eye might regard , them as belonging to the same species. Observe, however, the closely reflexed sepals of $R$. bulbosus; the spreading sepals, round peduncle, and stem without runners of $R$. acris; and the spreading sepals, furrowed peduncles, and stem with runners of $R$. repens. The brief characters which suffice to distinguish these species from each other are said to be diagnostic. It will be observed that the diagnoses of species rest apon comparatively slight modifications of structure. The diagnoses of genera rest upon characters of higher importance (characters more constant in the group than those used to distinguish species), and so on for the groups superior to the genus, the characters of each of which embrace, as we have already shown, those of all their subordinates. The method of denoting every plant and animal by two names, a generic and specific, on a uniform plan, was invented by Linnæus. The same method is carried out in the English names used by Mr. Bentham in his "Handbook of the British Flora," referred to in a note at page 129 .

The method of grouping genera into higher groups, according to their resemblance in characters of successive degrees of constancy, though indicated by the sane eminent man, has been the work of many collaborators, amongst whom the names of Jussieu, Brown, and De Candolle are pre-eminent.

4. Precisely as we group species under genera, so we group genera under Natural Orders. The Natural Orders again (to which sul)stantive names 
are applied for convenience), under Divisions; the Divisions under Subclasses and Classes, as we have already pointed out. Thus, the characters of a Class are common not only to its Subclasses and Divisions, but to the Natural Orders, Genera, and Species included in that Class. It follows, therefore, that the characters of a Class must be more constant and more general than those of a Subclass or Division, those of a Division than those of a Natural Order, of a Natural Order than those of a Genus, and of a Genus than of the Species which it includes.

5. Botanists distinguish as varieties groups of individuals of a species which are marked in c'ommon by some trivial character, subordinate in importance to the characters which are used to separate species. Thus, we may have white and red varieties of the same species of Rose, awnless and awned varieties of the same species of Wheat, \&c.; the colour of the flower of the Rose and the presence or absence of an awn in Wheat being characters too liable to variation to rerve to separate species.

6 . The following pages are devoted to an examination of representative types of most of the Natural Orders of flowering plants native in Britain.

I must here emphatically impress upon the baginner, that it is useless attempting to study this portion of the book without a constant reference to living specimens, without which any information he may acquire from it will be comjaratively unavailable when tested in the fielr. Numerous refr:rences are given to plants which show peculiar departures from the several Types. 
Specimens of these ought to be procured whenever it is possible, and drier for further use in the way described at page 308 . When a prepar :tion can be preserved without pressing it between papers, as, for example, many dry fruits, seeds, galls, spines, \&c., it would be well to have them thoroughly dried and mounted upon pieces of card, labelled with the name of the plant, the Natural Order to which it belongs, the particular in which it departs from the Type, \&c. Preparations of plants used for economic purposes, whether domestic, medicinal, in the arts, or otherwise, are always interesting, anil are very useful for purposes of illustration. A few of these, which may be easily obtained, I have indicated; but there are hundreds not mentioned and equally accessible. It is, indeed, scarcely possible to take a walk into the country, either in summer or winter, without meeting with objects which may help to throw light upon some question of botanical interest, and which may be turned to account by a teacher for purposes of illustration. To the late Professor Henslow nothing came amiss in this way, and his most instructive lessons were those illustrated by the simplest and commonest materials.

'The diagrams and accompanying text which I prepared for the Department of Science and Art, South Kensington, afford good pictorial illustrations of the Type-lessons. When possible, they ought to be accessible in class-rooms where Botany is taught, for reference by the students or scholars at their leisuro. 


\section{CLASS I.-DicOTYLEDONS.}

Sub-cr.ass. Dichlamydeæ. Division. Thalamifloræ.

* Pistil apocarpous.

1. Natural Oruer-Ranunculaceæ. The Ranunculus Family.

Distribution.-Generally diffused through both hemispheres, excepting between the Tropics (where they are chiefly confined to mountain ranges).-British genera 13 , species $31-32$.

Herbs (except Clematis). Stamens indefinite.

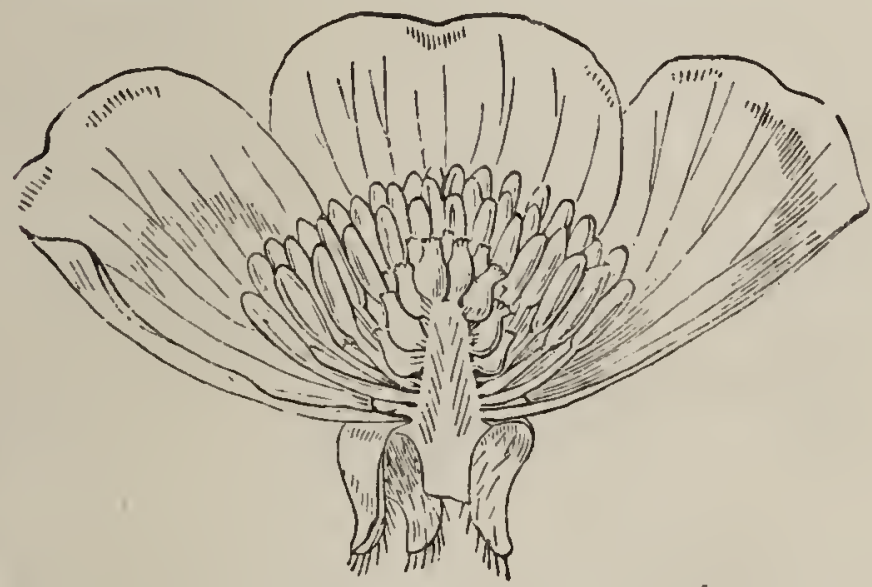

Frs. 71. Vertical section of flower of Bubbous Ranunculus.

Type-Bulbous Ranunculust (Rianunculus bulbosus).

+ The English names adopted in Mr. Bentham's "Handbook of the British Flora" are here made use of. There may be difference of opinion with regard to the plan of Binomial English nomenclature carried out in the former work ; but as in other respects the "Handbook" is so admirably suited to enable beginners to find ont the 
Herb, with thickened root-stock, radical and alteruate divided simple leaves, and terminal solitary yellow flowers.

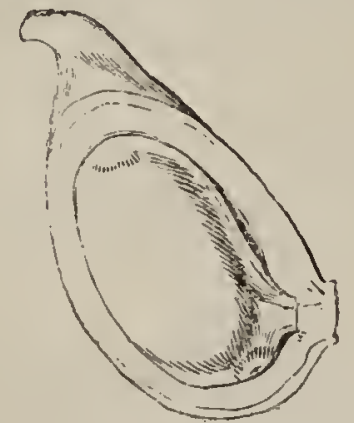

Fig. 72. Seetion of an achene of Bulbous Ranuuc llus.

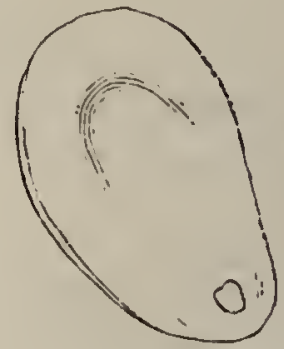

Fir. 73. Vertical sectiun of a scarl of saine.

\begin{tabular}{|l||c|l|l|}
\hline \multicolumn{1}{|c|}{ Organ. } & No. & \multicolumn{1}{c|}{ Cohesior.. } & \multicolumn{1}{|c|}{ Adhesion. } \\
\hline $\begin{array}{l}\text { Calyx. } \\
\text { sepals. }\end{array}$ & Polysepalous. & Inferior. \\
\hline $\begin{array}{l}\text { Corolla. } \\
\text { petals. }\end{array}$ & -5 & Polypetaious. & Hypogynons. \\
\hline $\begin{array}{l}\text { Stamens. } \\
\text { l'istil. }\end{array}$ & $-\infty$ & Polyandrous. & Hypogynous. \\
\hline carpels. & $\infty$ & Apocarpous. & Superior. \\
\hline Seeds. & Solitary, albuminous. \\
\hline
\end{tabular}

Important deviations from this type we find ill :

Common Clematis (Clematis Vitaika). Stem woody. Leaves opposite. Sepals 4, valvate. Corolla 0.

Wood Anemone (Anemone nemorosa). Flowèrs involucrate. Sepals 6 . Corolla 0.

numes of British plants, I agree with the view of tho late Professor Henslow, that the names employed in this work should be in conformity with thosa used by Mr. Bentham. 
Fetid Hellebore (Helleborus futidus). Petals 8-10, small and tubular. Seeds numerous.

Common Aconite (Aconitum Napellus). Flowers irregular. Carpels 3 ; each several-seeded.

Common Baneberry (Actcea spicata). Sepals 4. Petals 4. Carpel solitary, baccate when ripe.

In some species the stamens are very apt, under cultivation, to develop as petals, thus forming what are called "double flowers," as in Batchelors' Button (Ranunculus acris) and the white-flowered $R$. aconitifolius. The double $R$. orientalis is an esteemed Horist's flower. In Figwort Ranunculus (R. Ficaria) the petals vary in number from 8 to 11 , and the sepals are either 3 or 4 . This upecies, when growing in damp places, often produces axillary buds in the form of bulbels-small bulbs, which drop away from the parent, developing independent plants.

OBSERve the phyllodineous leaves of Ramunculus gramineus: the involucre of Anemone, in some species separated by a very short internode from the petaloid calyx, as in the Hepatica ( $A$. Hepatica): the irregular calyx and corolla of Monkshood (Aconitum) and Larkspur (Delphinium), and the spurred petals of Columbine (Aquilegia): the receptacle of Mousetail (Myosurus), the portion which bears the carpels lengthening out very much after flowering, so as to resemble a mouse's tail.

Compare the fruits of Ranunculus, Clematis (achene); Monkshood (follicle) ; Baneberry (berry); and Nigelia - an exotic genus found in gardens, with the exceptional character in the Ranunculus Family of coherent follicles, forming a capsule.

Many plants of the Order are very acrid and K 2 
poisonous. Tramps, to excite compassion, use the leaves of the Meadow and Celery-leaved Ranunculus ( $R$. acris and $R$. sceleratus), to produce blisters. Monkshood is very poisonous, and the root has been mistaken for Horse-radish, although destitute of its pungent smell, with fatal result. The root of $A$. ferox, an Indian species, affords one of the Bikh poisons used in the Himalaya to poison arrows for tigershooting.

2. Natural Order-Berberideæ. The Barberry Family.

Distrinution. - Confined to the North and South temperate zones, and intertropical mountains. But one species occurs in tropical Africa, and none in Australia.-One British genus, species 1 .

Shrub. Stamens 6, anthers opening by valves.

'Type-Common Iarberry (Berberis vulgaris).

A pale-green deciduous spinous shrub, with fascicled unifoliolate leaves, and recemose yellow flowers. (The only British species of the Family.)

\begin{tabular}{|c|c|c|c|}
\hline Organ. & No. & Cohesion. & Adhesion. \\
\hline $\begin{array}{l}\text { Calyx. } \\
\text { sepals. }\end{array}$ & 6 & Yolysepalous. & Inferior. \\
\hline $\begin{array}{l}\text { Corola. } \\
\text { petals. }\end{array}$ & 6 & Polypetalous. & Hypogynous. \\
\hline Stamens. & 6 & Hexandrous. & Hypogynous. \\
\hline $\begin{array}{l}\text { Pistil. } \\
\text { carpel. }\end{array}$ & 1 & Ipecarpous. & Superior. \\
\hline Seeds. & or & albuminous. & \\
\hline
\end{tabular}


The leaves of this Order belong to the compound type. In Berberis Aquifolium, common in shrubberies, they are unequally pinnate, but in most of the species of Barberry the terminal leaflet only is developed, so that the leaf appears simple. An articulation in the short petiole hetrays its true character. Several species of this Order, including one (Epimedium alpinum), occasionally found in wild places in England, but not native, are low herbs, with ternately divided leaves.

Observe the spines on a vigorous shoot of Barberry, bearing fascicles of leaves (leafy branches with undeveloped internodes) in their axils. If you trace these spines to the bottom of the shont, you will perceive that they pass into leaves, showing that the spines are leaves in an "arrested" condition: the trimerous arrangement of the parts of the flower, exceptional amongst Dicotyledons: the stamens opposite to the petals, because both stamens and petals are in 2 whorls of 3 each, the stamens of the outer whorl alternating with the 3 petals of the inner whorl, consequently opposite to the 3 petals of the outer whorl; the 3 inner stamens being in like manner opposite to the 3 inner petals : the irritability of the stamens; if touched at the base, on the iuner side, with a needle, they suddenly incline towards the pistil: the dehiscence of the anthers by valves.

There is a prejudice amongst farmers that the liarberry causes wheat grown near to it to becomo blighted; but the fungus which attacks the Barberry belongs to a different genus from that which infests wheat, and the prejudice has until 
recently been supposed to be without any reasonable foundation. Observations, however, by Oersted and De Bary prove, notwithstanding the differences which have been regarded as generic between the two fungi, that they are merely alternating generations of one and the same species. The wood of Barberry, especially of the root, is of a deep yellow colour, and is used as a dye. The acid fruit, with sugar, is used in preserves and confections.

3. Natural Order-Nymphæaceæ. The Waterlily Family.

Distribution. - Widely dispersed in the waters of Tropical and Temperate regions of both hemispheres.-British genera 2, species 2.

Floating Plants. Petals and stamens indefinite. Carpels indefinite (spuriously coherent).

Type-White Nymphæa (Nymphoea alba).

An aquatic herb, with cordate floating leaves and large white solitary flowers.

\begin{tabular}{|c|c|c|c|}
\hline Organ. & No. & Cohesion. & Adhesion. \\
\hline $\begin{array}{l}\text { Calyx. } \\
\text { sepals. }\end{array}$ & 4 & Polysepalous. & Inferior. \\
\hline $\begin{array}{l}\text { Corolla. } \\
\text { petals. }\end{array}$ & $\infty$ & Polypetalous. & $\begin{array}{l}\text { Hypogynous } \\
\text { and perigynous. }\end{array}$ \\
\hline Stamens. & $\infty$ & Polyandrous. & Epigynous. \\
\hline $\begin{array}{l}\text { Pistil. } \\
\text { carpels. }\end{array}$ & $\infty$ & Apocarpous. & Superior. \\
\hline Seeds. & \multicolumn{3}{|c|}{ Indefinite, with a double albumen. } \\
\hline
\end{tabular}


Onsenve the wide air-cavities in the petioles and peduncles: the very gradual transition from sepals to petals, and from petals to stamens; the floral receptacle, which develops around, and

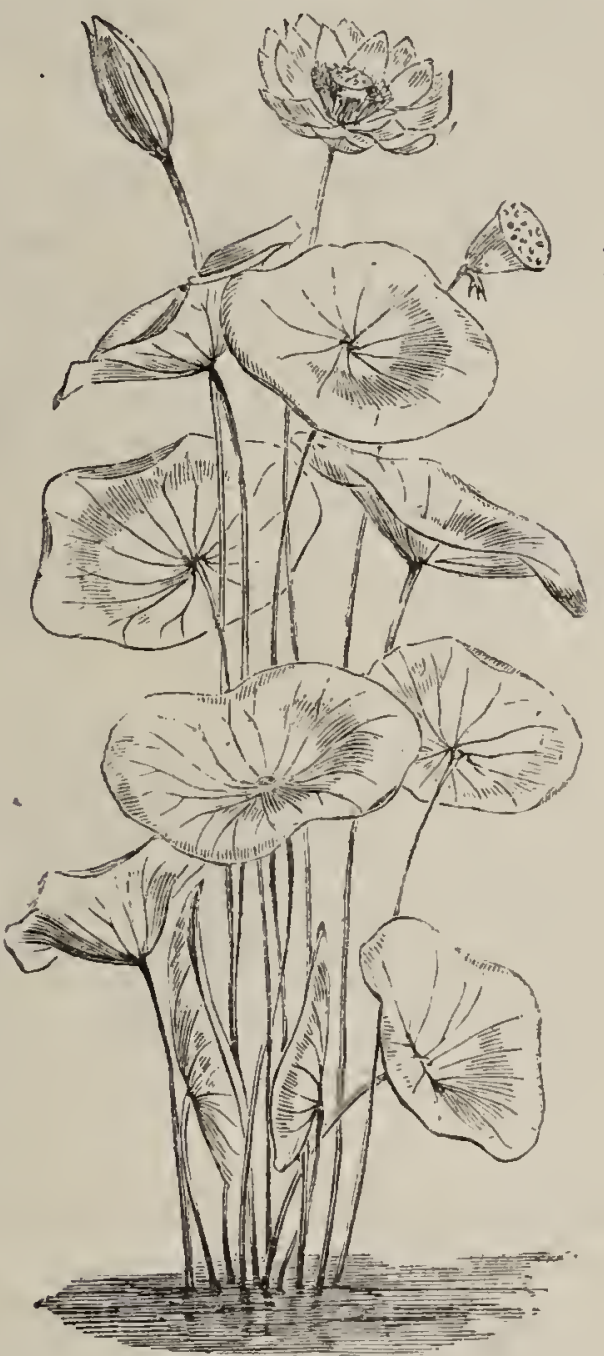

Fia. 74. Sacred Lotus (Nelumbium speciosum). Much reduced.

adnate to the carpels, so-that they become united into a spuriously syncarpous pistil, and the petals and stamens appear as though inserted upon the orary: the rays of the stigma, usually 
16 to 19 (varying from 13 to 24 ), which are opposite to the cells of the ovary, and not opposite to the dissepiments, consequently each ray of the stigma belongs to one carpel, as in truly apocarpous pistils: the arrangement of the ovules, which are spread over the sides of the ovaries; the double albumen of the seeds.

To the genus Nelumbium, with the carpels sc:iarately immersed in a large, obconical recepr-

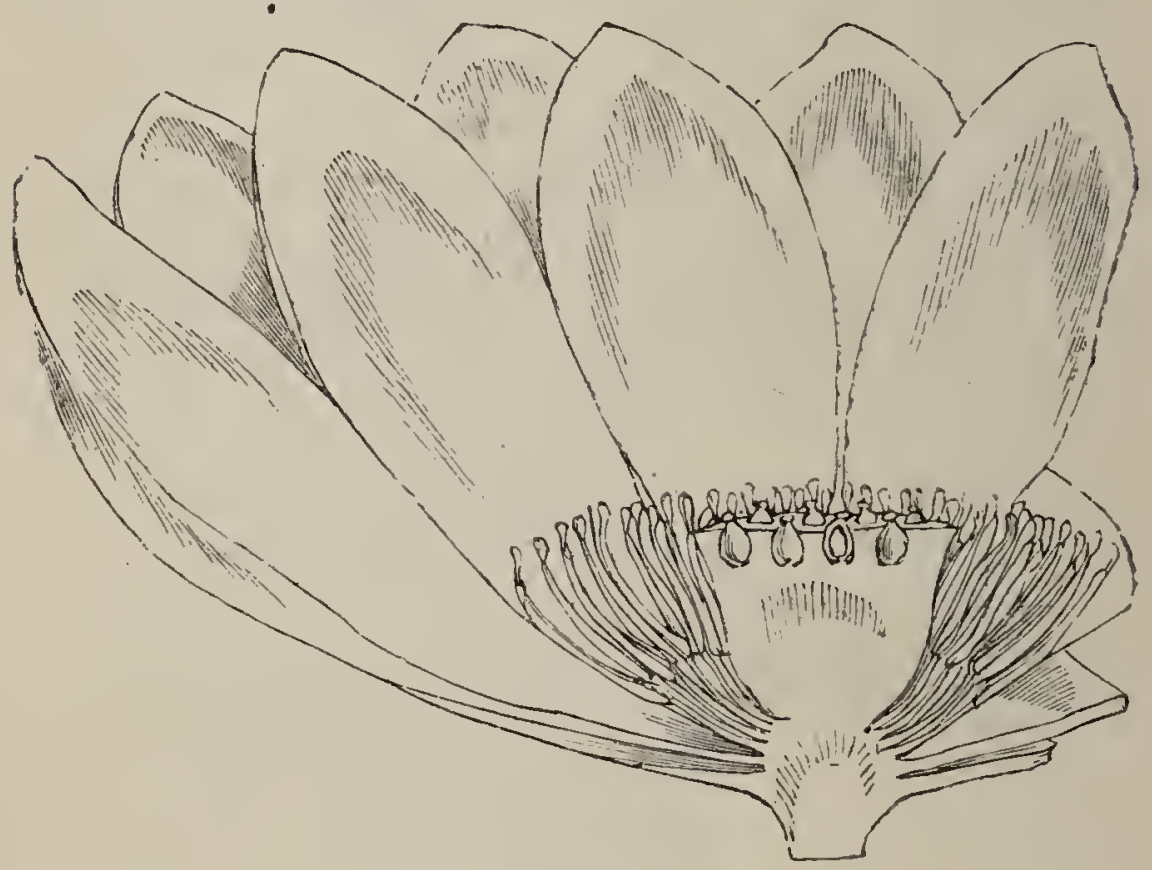

Fig. 75. Section of flower of Sacred Lotus, showing the carpels separately immersed in the top-shaped receptacle. Reduced.

tacle, belongs the Lotus (Fig. 74), regarded by the ancient Egyptians-as well as by the Chinese and Hindoos of the present day-as sacred. The flowers are represented in sculptures and paintings in tho Egyptian catacombs.

Victoria regia, a South American Water-lily, introduced into Fingland in 1849 , bears floating . 
leaves, which have been measured 12 feet across, and flowers about 1 foot in diameter when expanded.

$$
\text { * Pistil syncarpous. }
$$

4. Natural Order--Papaveracea. The Propy Family.

Distribution.-Excepting a few stragglers, confined to the North temperate zone.-British genera 5 , species 9 .

Herbs with milky or yellow juice. Flowers regular. Petals 4. Stamens indefinite. Placentas parietal.

Type-The Field Poppy (Papaver Rhacas).

An annual herb, with milky juice, and showy solitury fugacious flowers.

\begin{tabular}{|l||c|l|l|}
\hline \multicolumn{1}{|c|}{ Organ. } & No. & \multicolumn{1}{c|}{ Cohesion. } & \multicolumn{1}{c|}{ Adhesion. } \\
\hline $\begin{array}{l}\text { Calyx. } \\
\text { sepals. }\end{array}$ & 2 & Polysepalous. & Inferior. \\
\hline $\begin{array}{l}\text { Corolla. } \\
\text { petals. }\end{array}$ & 4 & Polypetalous. & Hypogynous. \\
\hline \begin{tabular}{l} 
Stamens. \\
\hline $\begin{array}{l}\text { Pistil. } \\
\text { carpels. }\end{array}$
\end{tabular} & $-\infty$ & Polyandrous. & Hypogynous. \\
\hline Seeds. & Syncarpous. & Superior. \\
\hline
\end{tabular}

As the sepals fill away before the crumpled petals expind, a bud should always accompany the specimen examined. Sepals falling away thus early are termed caducous.

A deviation from this Type we find in Common Celandine (Chelidonium majus), in which but 2 coherent carpels form the pistil. 
OBserrs the milky juice flowing freely from wounds in the Poppy. The Opium Poppy (Papaver somniferum) is cultivated to a great extent in the East, especially in India, for the sake of this juice, which, when dry, becomes brown, and forms the narcotic drug, opium. The well-known medicine, laudanum, and the poisonous alkaloid, morphia, are prepared from opium. The juice of the Poppy, used in opiummaking, is collected from gashes made in the unripe pericarp. The juice of Common Celandine is of a bright orange colour.

Observe, also, a cross section of a large 1'oppyhead, such as druggists sell; the placentation is parietal, as the infolded margins of the carpels ars not united in the centre. The seeds are scattered over the sides of the projecting partial dissepiments, instead of being confined to their inner edges, as is normally the case. A capsule is calculated to contain 32,000 seeds. An oil is obtained from the seeds, used sometimes to adulterate olive oil. Observe also the floral receptacle of the Californian genus, Eschscholtzia, a common garden annual, with orange flowers; the receptacle grows up around the lower part of the ovary, without becoming adnate to it, forming a sheath to its base. The stamens and envelopes of the flower are carried up with it, and consequently become perigynous.

Compare the relation of the rays of the stigma to tho divisions of the ovary in the Poppy and the Water-lily. In the former the pistil is essentially syncarpous, and the carpels are coherent throughout, so that each ray of the stigma is immediately above, and opposite to, the 
partial dissepiments, and, like the dissepiments, double.

5. Natural Order-Fumariaceæ. The Fumitory Family.

Distribution.-Widely dispersed in temperate regions; a few here and there in the 'Tropics.British genera 2, species 3 .

Slender herbs with watery juice. Flowers irregular. Stamens 6, diadelphou's.

Type-Common Fumitory (Fumaria officinalis), A delicate climbing annual herb, with muchdivided leaves, and watery juice.

\begin{tabular}{|c|c|c|c|}
\hline Organ. & No. & Cohesion. & Aclnesiun. \\
\hline $\begin{array}{l}\text { Calyx. } \\
\text { seputs. }\end{array}$ & 2 & Polysepalous. & Inferior. \\
\hline $\begin{array}{l}\text { Corolla. } \\
\text { petals. }\end{array}$ & 4 & Polypetalous. & Hypogynous. \\
\hline Stamens. & 6 & Diadelphous. & Hypogynous. \\
\hline $\begin{array}{l}\text { Pistil. } \\
\text { carpels. }\end{array}$ & 2 & Syncarpous. & Superiol: \\
\hline Seeds. & \multicolumn{3}{|c|}{ Solitary, albuminous. } \\
\hline
\end{tabular}

Observe the irregular corolla, one of the petals being gibbous at the base. In Dicentra, common in cultivation, both of the outer opposite petals are similarly gibbous: the anther of the middle stamen of each bundle of three is 2-celled, of the lateral stamens 1-celled.

6. Natural Order-Cruciferæ. The Crucifer Family.

Distribution.-Represented in both hemispheres to the limits of vegetation, both in lititude and altitude; by far most abundant, 
however, in Southern Europe and temperate Asia. Rare between the Tropics or absent excepting in mountainous regions. - British genera 28, species 66 .

\section{Herbs. Sepals 4. Petals 4. Stamens tetradynamous.}

\section{Type - Common Wallflower (Cheiranthus} Cheiri).

An herbaceous plant, somewhat woody below, with alternate entire exstipulate leaves, and race. mose ebracteate flowers.

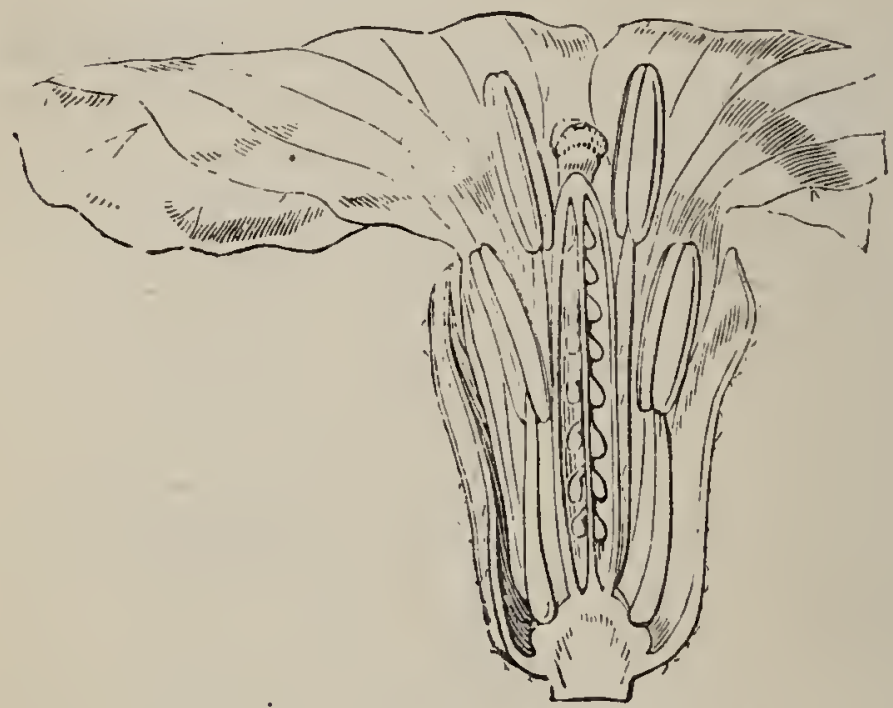

F1r. 7 i. Vertical section of a flower of Wallflower

\begin{tabular}{|c|c|c|c|}
\hline Organ. & No. & Cothesion. & Adhesion. \\
\hline $\begin{array}{l}\text { Calyx. } \\
\text { sepuls. }\end{array}$ & 4 & Polysepalous. & Inferior. \\
\hline $\begin{array}{l}\text { Corolla. } \\
\text { petals. }\end{array}$ & 4 & Polypetalous. & Hypogynous. \\
\hline Stamens. & 6 & Tetradynamous. & Hypogynous. \\
\hline $\begin{array}{l}\text { Pistil. } \\
\text { carpels. }\end{array}$ & 2 & Syncarpous. & Superior. \\
\hline Seeds. & Ser & al, exalbuminov & , parietal. \\
\hline
\end{tabular}


Deviations from the Type in this very large Order are unimportant so far as the general aspect of the species is concerned; depending principally upon modifications of the fruit and seeds. In some few species 2 , in others 4 of the stamens are undeveloped. In one exotic species the stamens are numerous. They thus lose the typical tetradynamous character, which is usually explained by supposing either the constant suppression of 2 short stamens of an outer whorl of 4 , or the collateral fission of 2 of the stamens of a single whorl of 4 .

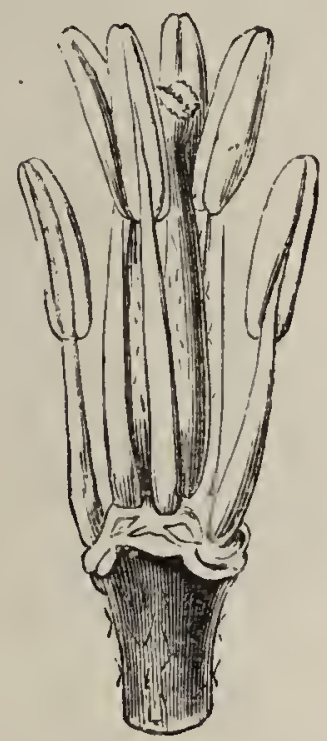

F1G. 7. Stamens (tetradynainous) and pistil of the Wallfower.

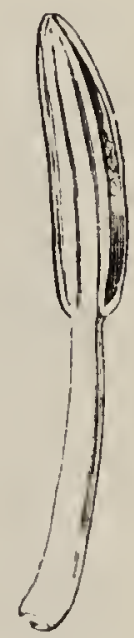

FIG. 78. Single stan:ıen of silute.

OBsfrnve the spuriously lateral racemes of Lesser Senebiera (Senebiera didyma), an exotic weed, introducerl in waste ground in the South of England. The racemes are, as is usual in the Order, really terminal, but the axillary bud given off below each raceme soon overtops it: the axillary bulbels 
of Bulbiferous 'Toothcress (Dentaria bulbifera): the spurious septum which usually divides the ovary of Crucifers into 2 cells, developed from the cellular tissue of the opposite parietal placentas, the lobes of the stigma being opposite to the placentas.

Compare the long capsule of Wallflower (a sili$q u a)$; the short capsule of Shepherd's-purse Capsell (a silicula); the siliqua of Radish, - an indehiscent and jointed lomentaceous siliqua; and the 1-seeded fruit of Dyer's Woad (Isatis tinctoria).

Compare, with regar? to the relation of the septum to the greater or smaller diameter of the fruit, Lunaria (with a broad septum) and Shepherd's-purse Capsell (with a narrow septum) : also

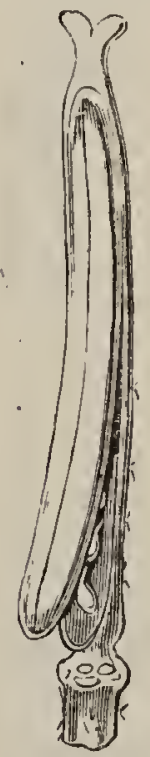

Fig. 79. Capsule (siiiqua) of Wallflower, showing one of the valves dehiscing from below upwards.

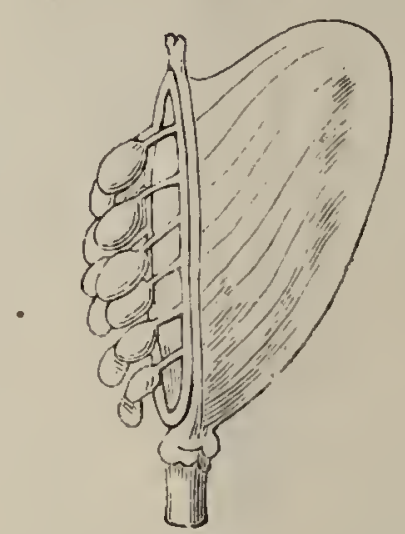

Fig. So. Causuie (silieula) of Shepherd's - purse Capsell, showing one valve removed, and the seeds attached by their pedieles (funicles) to the replum or frame uniting the valves, and which remains after they fall.

the exalbuminous seeds of Wallflower, having the radicle curved over the edges of the cotyledons 
(acrumbent); of Sisymbrium, with the radicle curved over the back of one of the cotyledons (incumbent); of Radish, the same with the cotyledons folded; and the tripartite cotyledons of Garden Cress (Lepidium sativum).

All Crucifers are wholesome, and many are anti-scorbutic. Amongst those in household use are-Turnips, Radish. (root) ; Kohl-rabbi (stem); Horse-radish (rhizome); Mustard, Cress, Cab-

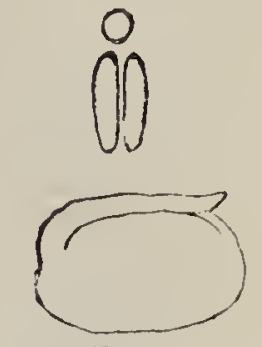

Fis. 81. The ac. cumbent embryo of $\pi$ all. flower. bage, Water-cress, Sea-Kale (herbage); Caulifiower, Broccoli-both varieties of the Cabbage(flowers); Mustard (seeds).

Valuable oil is expressed from the seeds of Field Brassica (Brassica campestris) and its varieties.

Woad, a blue dye obtained from Dyer's Woad, is stated to have been used by the ancient Britons to paint their persons.

A Turnip hollowed out and suspended with the crown downwards, and then filled with water, will soon push its leaves, which curl up and cover the Turnip). A few Hyacinths may be planted inside.

7. Natural Order-Resedaceæ. The Mignonette Fanily.

Distribution.-Chiefly confined to countries bordering on the Mediterranean. Absent from America.-One British genus, species 3.

Herbs. Petals 4-6, palmatified. Stamens indefinite, upon a lateral disk. I'lacentas parietal.

Type-Sweet Mignonette (Reseda odorata).

An herbaceous (garden) annual, with alternate 
entire or lobate exstipulate leaves, and terminal racemes of small slightly irregular flowers.

\begin{tabular}{|l||c|l|l|}
\hline \multicolumn{1}{|c|}{ Organ. } & No. & \multicolumn{1}{c|}{ Cohesion. } & \multicolumn{1}{c|}{ Adhesion. } \\
\hline $\begin{array}{l}\text { Calyx. } \\
\text { sepals. }\end{array}$ & $4-6$ & Polysepalous. & Inferior. \\
\hline $\begin{array}{l}\text { Corolla. } \\
\text { petals. }\end{array}$ & $4-6$ & Polypetalous. & Hypogynous. \\
\hline \begin{tabular}{l} 
Stamens. \\
\hline $\begin{array}{l}\text { Pistil. } \\
\text { carpels. }\end{array}$
\end{tabular} & $\infty$ & Polyandrous. & Hypogynous. \\
\hline $\begin{array}{ll}\text { Seeds. } \\
\text { Syncarpous. }\end{array}$ & Superior. \\
\hline
\end{tabular}

Observe the multifid limb of the petals, attached to a broad claw : the stamens inserted into a unilateral hyporynous disk: the parietal placentation: the pericarp opening at the apex before the seeds are ripe.

Dyer's Mignonette or Weld (R. Luteola) is cultivated for dyeing yellow.

8. Natural Order-Cistaceæ. The Cistus Family.

Distribution.-Chiefly confined to the Mediterranean region. A few occur in America. -Une British genus, species 4.

Annuals, or wiry perennials. Leaves opposite. Flowers regular. Sepals 3 or 5 (2 small). Stamens indefinite.

Type - Common Rockcist (Helianthemum vulyare).

A low woody perennial, with wiry stems, and showy fargicious regular flowers. 


\begin{tabular}{|c|c|c|c|}
\hline Organ. & No. & Cohesion. & Adhesion \\
\hline $\begin{array}{l}\text { Calyx. } \\
\text { sepals. }\end{array}$ & 5 & Polysepalous. & Inferior. \\
\hline $\begin{array}{l}\text { Corolla. } \\
\text { petuls. }\end{array}$ & 5 & Polypetalous. & Hypogynous. \\
\hline Stamens. & $\infty$ & Polyundrous. & Hypogynous. \\
\hline $\begin{array}{l}\text { Pistil. } \\
\text { carpels. }\end{array}$ & 3 & Syncarpous. & Superior. \\
\hline Secds. & \multicolumn{3}{|c|}{ Several, albuminous ; embryo curved } \\
\hline
\end{tabular}

There are 5 carpels in Cistus. Many species of Rockcist are commonly cultivated in shrubberies and on rock-work.

9. Natural Oriter-Violacex. The Violet Family.

Distribution.-Widely spread through both hemispheres, the woody species being chiefly confined to the Tropics and South temperate zone. -One British genus, species 5-6.

Herbs. Leaves alternate. Flower's irregular. Stamens 5, connective produced above the anther-cells.

Placentas 3, parietal.

Type-Sweet Violet (Viola odorata).

An herbaceous peremial, with stjpulate alternate or radical leaves, and pedunculate bracleolate irregular flower's.

\begin{tabular}{|c|c|c|c|}
\hline Organ. & No. $\mid$ & Cohesion. & Adhesion. \\
\hline $\begin{array}{l}\text { Calyx. } \\
\text { sepals. }\end{array}$ & 5 & Polysepalous. & Inferior. \\
\hline $\begin{array}{l}\text { Corolla. } \\
\text { petals. }\end{array}$ & 5 & Polypetalous. & Hypogynous. \\
\hline Stamens. & 5 & Pentandrous. & Hypogynous. \\
\hline $\begin{array}{l}\text { Pistil. } \\
\text { carpels. }\end{array}$ & 3 & Syncarpous. & Superior. \\
\hline Seeds. & Indef & inite, albumino & (parietal). \\
\hline
\end{tabular}


OBSERVE the spur of the larger and lower (anterior) petal, sheathing two narrow dorsal appendices from the base of the connective of the two anterior anthers: the small, almost apetalous, closed flowers, which appear after the petaloil large fiviers, in May or June, and which, selftertilized, bcar fruits with numerous seeds: the dehiscence of the $\mathbf{i}$-celled fruit, which separates into 3 valves by the dorsal sutures of the carpels

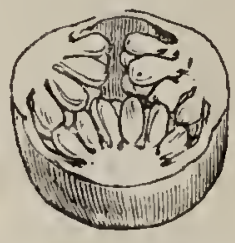

Fic. 82. Trans verse section of the 1-celled ovary of Violet, showing 8 parietal placentas.

(loculicidal dehiscence), each valve bearing a (parictal) row of seeds.

Besides Sweet Violet, the Pansy, deriver from $V$. tricolor and $V$. altaica, is very common in gardens. An infusion of the petals of the Violet is a delicate test for acids and allialies.

10. Natural Order-Caryophyllaceæ. The Pink Family.

Distribution.-Represented in both hemispheres from the Arctic zone to the Equator, though rare between the Tropics, and chiefly confined to great elevations. Most numerous in Europe and temperate Asia.-British genera 14, species 45 .

Herbs. Leaves opposite. Flowcrs regular. Stanens definite. Placenta free-central. 
Type-Bladder Silene (Silene inflata).

An herbaceous perennial, with ascending stems, opposite entire leaves, definite dichotomous in florescence, and regular flowers.

\begin{tabular}{|l||r|l|l|}
\hline \multicolumn{1}{c|}{ Organ. } & No. & \multicolumn{1}{c|}{ Cohesion. } & \multicolumn{1}{c|}{ Adhesion. } \\
\hline $\begin{array}{l}\text { Calyx. } \\
\text { sepals. }\end{array}$ & 5 & Gamosepalous. & Inferior. \\
\hline $\begin{array}{l}\text { Corolla. } \\
\text { petals. }\end{array}$ & 5 & Polypetalous. & Hypugynous. \\
\hline \begin{tabular}{l} 
Stamens. \\
\hline $\begin{array}{l}\text { Pistil. } \\
\text { carpels. }\end{array}$
\end{tabular} & \begin{tabular}{ll} 
Decandrous. \\
\hline Seeds.
\end{tabular} & $\begin{array}{l}\text { Syncarpous. } \\
\text { Indefinite, albuminous, embryo curved. }\end{array}$ \\
\hline
\end{tabular}

OBSERVe the free central placenta, characteristic of the Order. Inside and at the base of tho ovary traces of arrested dissepiments may be found, indicating that the pla-

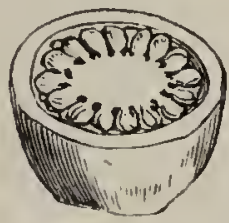

Fig. S3. Transterse section of an ovary. showing free central placentation. centa results from the axile cohesion of the carpels. Observe, also, the somewhat berried fruit of Cucubalus. A capsule is the characteristic form of fruit in the Order.

Several species of the Order are common in gardens, as Clove-pinks, Piccotees, and Carnations, derived from Dianthus Caryophyllus (from the specific name of which species the name of the Natural Urder is derived), Sweet William (D. barbatus), Pinks (various species of Dianthus), species of Lychnis, and Soapwort (Saponaria). The last-named and some others of the Family.

L 2 
contain a considerable quantity of carbonate of soda or of potash, and may be used in washing linen; hence the name "Soapwort."

Tufts of a Sandwort (A renaria) are in the Kew Museum, brought from an elevation of 14,000 to 18,000 feet in the Himalaya, by Drs. Hooker and Thomson.

11. Natural Order-Hypericinex. 'The Hypericum Family (St. John's-worts).

Distribution. - Dispersed through tropical and temperate regions of both hemispheres.-One British genus, species 11 .

Shrubs or herbs. Leaves opposite. Flowers regular. Sepals imbricate. Stamens indefinite, polyadelphous.

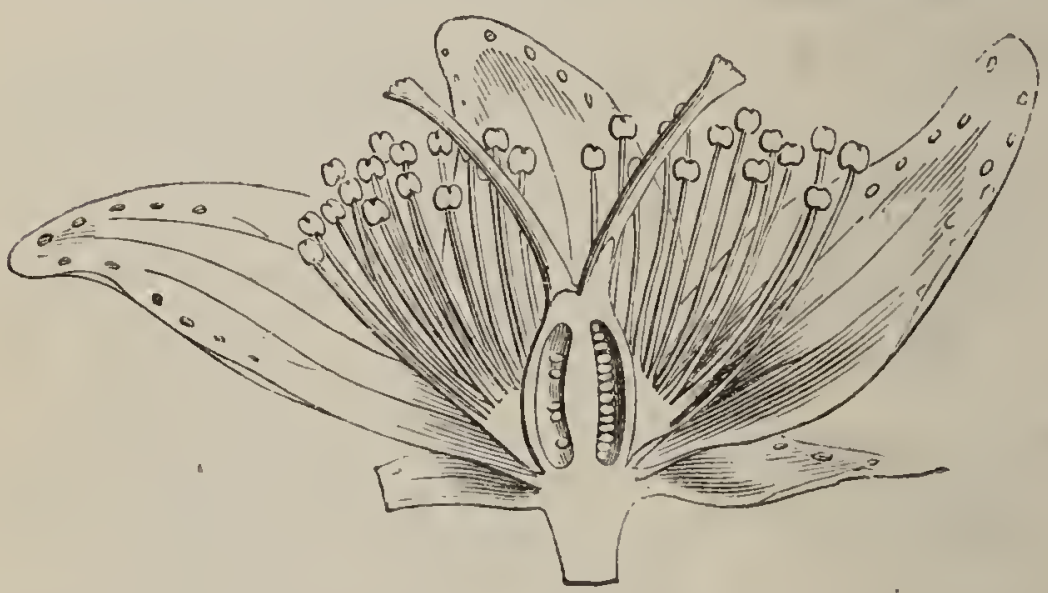

Fro. 84. Vertical section of a flower of Hypericum perforatum.

Type-Common Hypericum (Hypericum perforaturn).

A perennial erect herb, with opposite entire glandular-dotted leaves, and terminal cymoso yellow regular flowers. 


\begin{tabular}{|c|c|c|c|}
\hline Organ. & No. & Cohesion. & Adhesion. \\
\hline $\begin{array}{l}\text { Calyx. } \\
\text { sepals. }\end{array}$ & 5 & P'olys:epalous. & Inferior \\
\hline $\begin{array}{l}\text { Corolla. } \\
\text { petals. }\end{array}$ & 5 & Polypetalous. & Hзрogynous. \\
\hline Stamens. & $\infty$ & Polyadelphons. & Hypogynous. \\
\hline $\begin{array}{l}\text { Pistil. } \\
\text { carpels. }\end{array}$ & 3 & Synearpous. & Superior \\
\hline Seeds. & Indef & finite, exalbumir & \\
\hline
\end{tabular}

Obsenve the immersed glands of the leaves, appearing like translucent dots when held up to the light: the dark "glands" on the sepals and petals : the unequal-sided petals.

Hypericum is the only British genus with polyadelphous stamens.

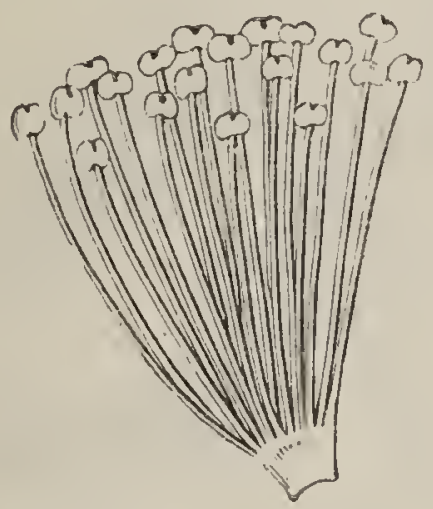

Fis. 85. One of tha bundles of stimens from the flower of

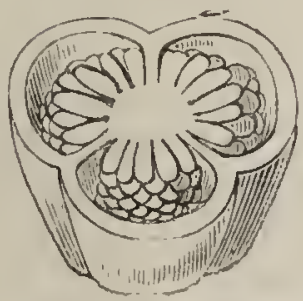

Fin. S6. flataliense section of the 3-eclled oviry of silne, showing axile placentation.
Hypericum.

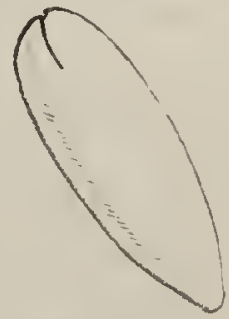

Fra. S7. Embryo of sime: the short notch" separates the cotyledons. 
A Natural Order (not European) allied to the Hypericums-Ternströmiacer-includes the Tea shrub (Thea chinensis), the dried leaves of which we import as "l'ea" in enormous quantities from China and, of late years, from India. The original culture of tea was confined to China, where it has been in use from remote antiquity ; tradition representing it as having been introduced to human notice in fabulous times by a monkey. It is not, however, known in the wild state in China, though it is found native in the jungles of North-Eastern India. From the cultivated native Indian variety, and from Chinese

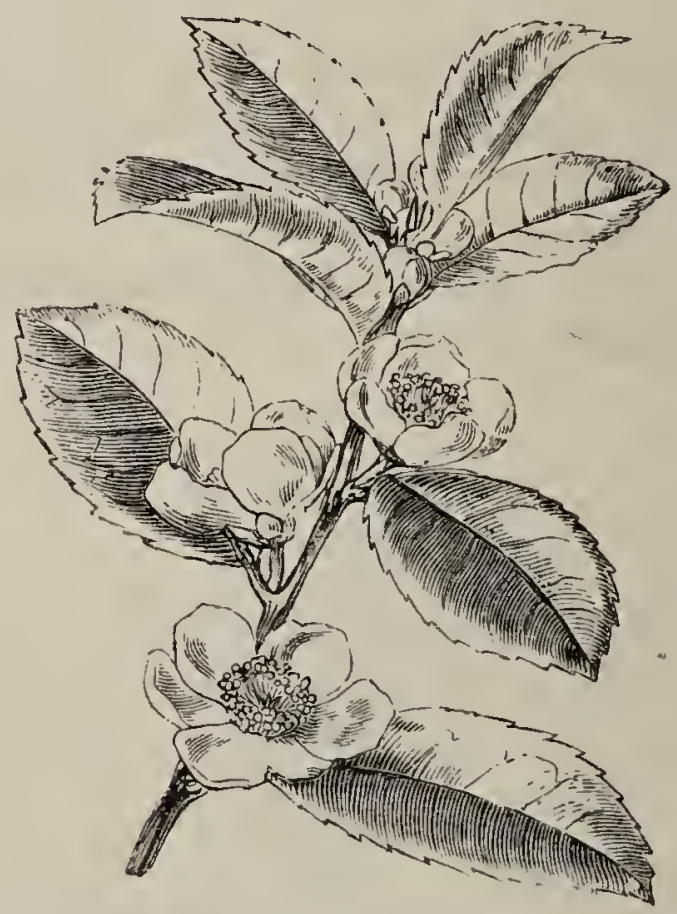

F1G. Ss. Teil shrub (Thea chinensis). Reduced.

plants introduced into India, large quantities of T'ea are now prepared. The total import of 'Tea into the United Kingdom in 1872 exceeded 185,000,000 lbs., 127,000,000 lbs. being entered for home use. In the year y666 Tea was sold in England at $60 \mathrm{~s}$. per pound.

Black and green Tea may be prepared from any of the varieties of the Tea plant by peculiar methods of drying; the leaves which are intended for green 'Tea being dried 
more rapidly than those destined for black. Inferior kinds of green are artificially coloured. "Brick Tea," used in Central Asia, is made frum common kinds and refuse, mixed with bullocks' blood, pressed and dried in moulds. When used, it is boiled with salt, butter, \&c. Brick tea has lately been sold in the London market for re-exportation to Russia.

To the same Natural Order belong also the favourite Camellias of our plant-houses, evergreen shrubs introduced from Japan. The genus Camellia is coufined to Eastern and Southern Asia. It is so nearly allied to Thea as scarcely to merit generic separation. The species are prone to the substitution of petals for stamens in their flowers : hence the Camellia is rarely seen with single flowers.

\section{Natural Order-Linacer. The Flax Family.}

Slender herbs. Flowers regular. Sepals imbricate. Stamens definite. Placentas axile.

Distribution.- - Scattered through the Tropics, and North Temperate Zone of both hemispheres. -British genera 2, species 5 .

Type-Common Flax (Linum usitatissimum).

An erect tall and slender annual herb, with narrow alternate leaves, and conspicuous blue regular flowers.

\begin{tabular}{|c|c|c|c|}
\hline Organ. & No. & Cohesion. & Adhesion. \\
\hline $\begin{array}{l}\text { Calyx. } \\
\text { sepals. }\end{array}$ & 5 & Polysepalous. & Inferior. \\
\hline $\begin{array}{l}\text { Corolla. } \\
\text { petals. }\end{array}$ & 5 & Polypetalous. & Hypogynous. \\
\hline Stamens. & 5 & Pentandrous. & Hypogynous. \\
\hline $\begin{array}{l}\text { Pistil. } \\
\text { carpels. }\end{array}$ & 5 & Syncarplous. & Superior. \\
\hline Beeds. & \multicolumn{3}{|c|}{ In pairs in each cell, } \\
\hline
\end{tabular}


OBserve an inner whorl of five stamens imperfectly developed, indicated by short filaments without anthers. In some exotic allies the stamens are decandrous from the inner five becoming antheriferous. A cross section of the ovary exhibits, apparently, ten cells. There are really five, each of which becomes more or less "spuriously" divided by the infolding of the dorsal suture of cach carpel. Note, also, the tendency to a dimorphlic condition in some species of Flax, manifest in the different relative lengths of stamens and pistil in different individuals of the same species; a natural contrivance to favour the crossing of the flowers by insect agency.

The words line, linen, linseed, lint, and the Latin word Linum, are said to be derived from the Celtic word llin, thread. Flax has been cultivated from time immemorable for the sake of the fibre from which linen is prepared, afforded by its liber-layer. All the cloth of the ancient Egyptians left to us in their tombs is of Flax. At present, besides its cultivation to a considerable extent in Great Britain, especially in Ireland, it is largely grown in Russia, Prussia, Belgium, and the north of France. In 18,1 upwards of 2,500,000 civts. of Flax and Tow, or Codilla of Flax, were imported into the United Kingdom.

Compare, under the microscope, the fibre of Flax with Cotton. Flax consists of long, thickwalled liber-cells, apparently united end to end, resembling jointed cylindrical rods. Fibres of linen from Egyptian mummies may also be compared with fibres of cotton cloth from the Peruvian tombs. (Seo page 156.)

The seeds of the Flax plant, called Linseed, are 
very largely imported for the expression of the valuable "Linseed oil "which they contain. The refuse of the seeds, after the oil is expressed, is made into Linseed-cake or "Oil-cake," used to feed cattle. More than 1,600,000 quarters of Linseed were imported in 1868.

13. Natural Order-Malvacex. The Mallow l'amily.

Distributron.-A widely diffused Natural Order ; most abundant in tropical and sub-tropical regions.-British genera 3 , species 6 .

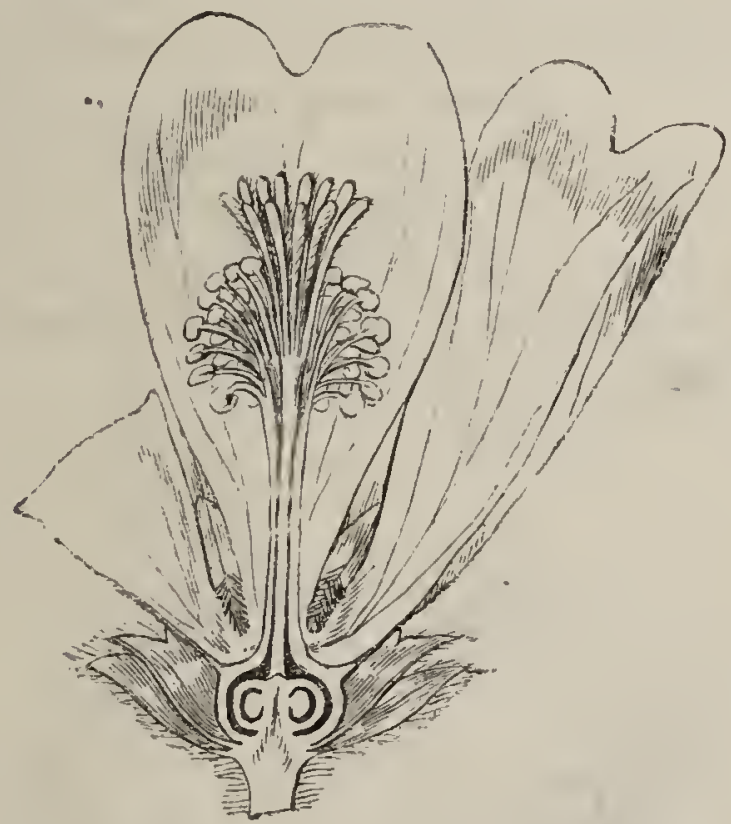

Fis. 89 . Vertical section of a flower of Mallow.

Herbs. Flowers reģular. Sepals valrate. Stamers indefinite, monadelphous.

Type-Common Mallow (Malva sylvestris).

A bionnial herb, with simple alternate stipulate rotundate leaves, and axillary fascicles of regular purplish flowers. 


\begin{tabular}{|c|c|c|c|}
\hline Organ. & No. & Cohesion. & Adhesion. \\
\hline $\begin{array}{l}\text { Calyx. } \\
\text { sepals. }\end{array}$ & 5 & Gaınosepalous. & Inferior. \\
\hline $\begin{array}{l}\text { Corolla. } \\
\text { petals. }\end{array}$ & 5 & Polypetalous. & $\begin{array}{l}\text { Inserted on } \\
\text { stimells. }\end{array}$ \\
\hline Stamens. & $\infty$ & Monadelphous. & Hypogynous. \\
\hline $\begin{array}{l}\text { Pistil. } \\
\text { carpels. }\end{array}$ & $\infty$ & Syncarpous. & Superior. \\
\hline
\end{tabular}

Observe the 3 bracts closely applied to the calyx, forming an involucre, sometimes called an epicalyx: the valvate restivation of the lobes of the calyx, and imbricated (contorted) xstivation of the corolla : the slight adhesion of the petals t.) the stamen-tube at its base: the 1-celled anthers, - an unusual condition, but characteristic of Malvaceæ.

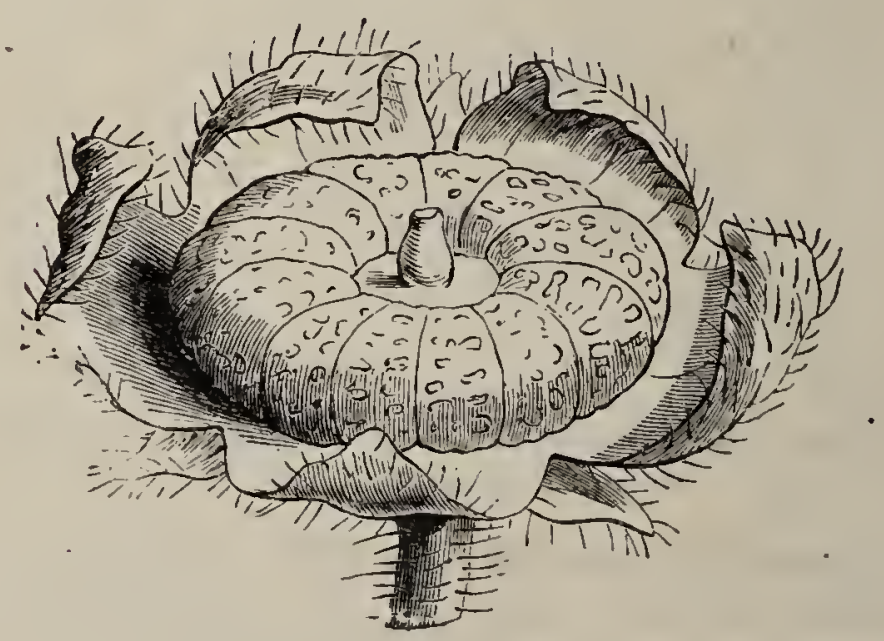

F1a. 90. Syncarpous fruit of Mallow, consisting of numerous carpels in a siugle verticil. The calyx and epicalyx are persistent 


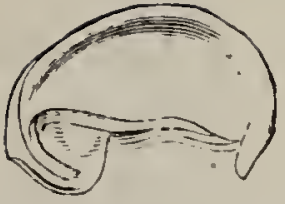

FIG 91. Embryo of Mallow, with folded cotyledons.
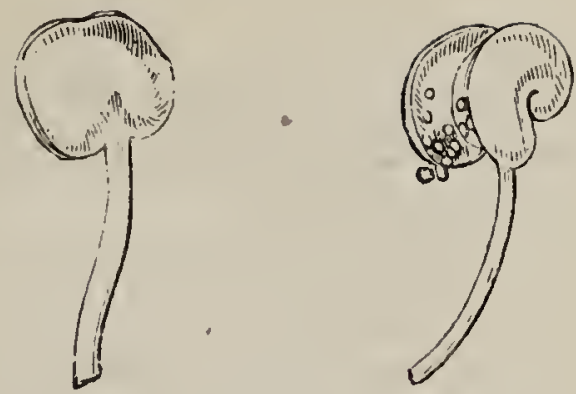

Fia. 92. Singrle stamen of same, with 1-celled antlier.
Fio. 93. Anther after dehiscence.

Plants of this Natural Order are destitute of noxious properties; many are mucilaginous, and

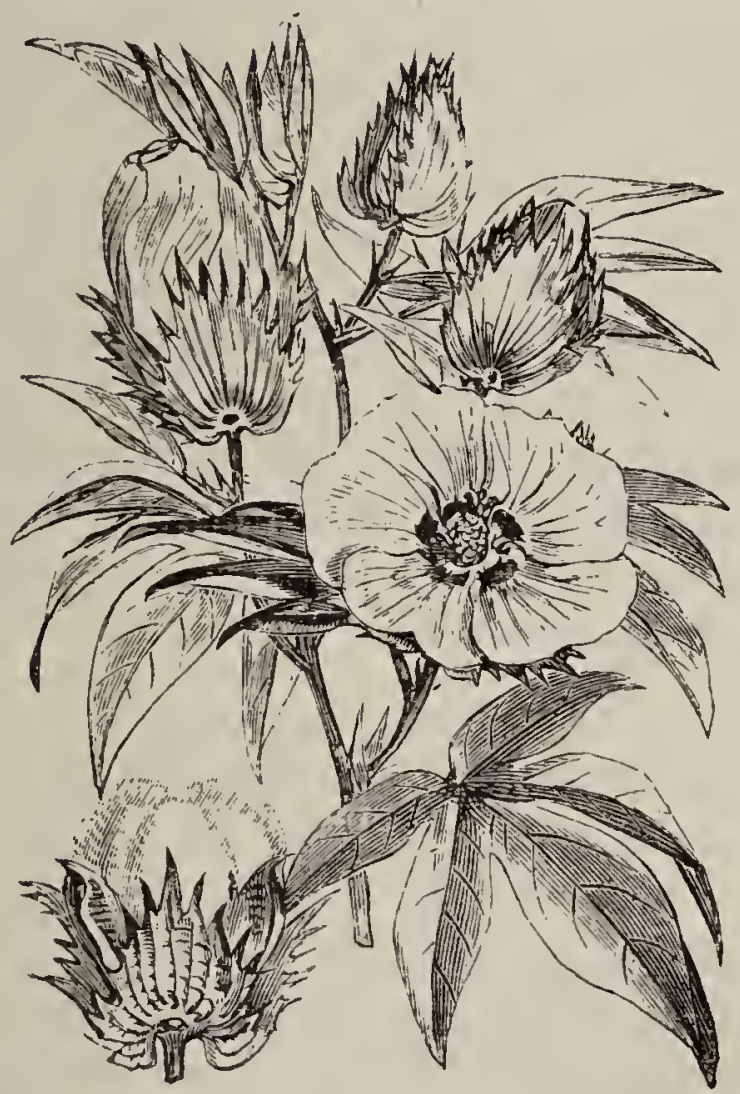

Fig. 94. Cotton (Gossyniam Linbudense). Reduced. 
the liber affords a useful fibre. The species of pre-eminent importance for textile purposes are the cotton-producing plants, belonging to the exotic genus Gossypium.

In 1871 the import of raw Cotton into the United Kingdom exceeded fifteen million hundredweights; of which upwards of nine millions were imported from the United States, and nearly fuur millions from British India.

Cotton consists, not as flax of fibres of liber, but of the delicate, long, thin-walled hairs which clothe the seeds. These hairs when dry become flattened and twisted. The commercial value of Cotton depends upon the length and tenacity of these hair-cells. Lamp-oil is obtained from the seeds, and the refuse is made up into oil-cake for cattle-feeding.

14. Natural Onder.-Tiliaceæ. The Lime Family.

Distribution.-Restricted to the Tropics of both hemispheres, with comparatively few representatives in the North temperate zone. - One British genus, species 1.

-Trees. Leaves alternate. Sepals valvate. Stamens indefinitr,

Type-Common Lime (Tilea exropoea).

A large deciduous tree, with alternate obliquely cordate leaves, and peduncles adnate to leafy bracts. 


\begin{tabular}{|l||r|l|l|}
\hline \multicolumn{1}{|c|}{ Organs. } & No. & \multicolumn{1}{c|}{ Cohesion. } & \multicolumn{1}{|c|}{ Adhesion. } \\
\hline $\begin{array}{l}\text { Calyx. } \\
\text { sepals. }\end{array}$ & 5 & Polysepalous. & Inferior. \\
\hline $\begin{array}{l}\text { Corolla. } \\
\text { pelals. }\end{array}$ & 5 & Polypetalous. & Hypogynous. \\
\hline \begin{tabular}{l} 
Stamens. \\
\hline $\begin{array}{l}\text { Pistil. } \\
\text { rarpels. }\end{array}$
\end{tabular} & $\infty$ & $\begin{array}{l}\text { Polyandrous. } \\
\text { Syncarpous. }\end{array}$ & Ilypogynoss. \\
\hline \begin{tabular}{l} 
Seeds. \\
\hline
\end{tabular} & 1 or 2, albuminous. \\
\hline
\end{tabular}

Observe the obliquity of the base of the leaflade, characteristic of the Lime. The same kind of obliquity, though usually much more decided, obtains in nearly all the species of a s mall, herbaceous, exotic Natural Order, in no riay allied to the Iimes-the Begoniacea-many species of which are favourites in plant-houses from the beanty of their variegated leaves. Observe, also, the bract of the Lime, adnate to the r eduncle. In the axil of the leaves bearing the reduncles may be scen a small resting-bud, which grows out into a leafy branch in the following sieason.

Bast or Russia-matting is the liber of the Lime, torn into strips and coarsely plated. It is principally imported from Russia. Jute is a valuable Indian fibre afforded by a species of Corchorus. It is obtained of great length and possesses a satiny lustre. In India it is used for making rice and sugar bags, called Gunny-bags. 
An aliied Family (not British), Byttneriacex, atfords Cocoa, which is preparerl from the seeds of Theobromn Cacao, grown in 'Trinidad, the northern provinces of South America, and Brazil. The seeds are contained, closely packed, in a pericarp $4 \mathrm{in}$. to $6 \mathrm{in}$. long, and $2 \mathrm{in}$.

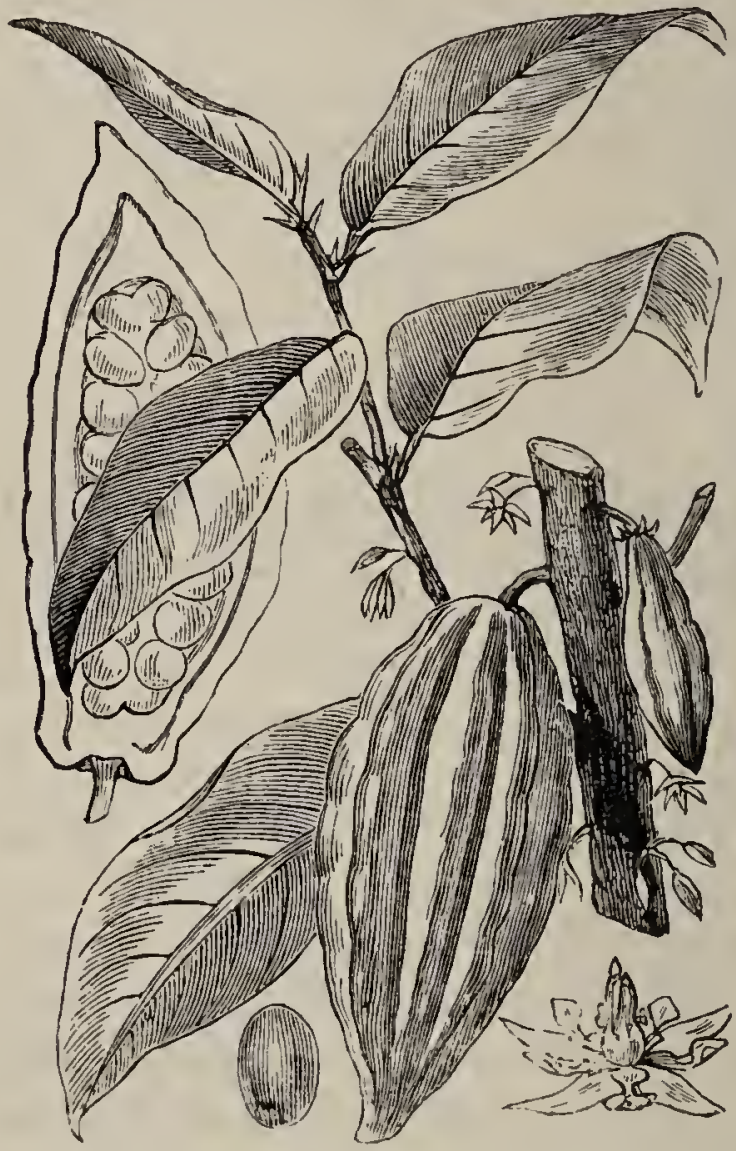

Fia. 95. Cocoa and Chocolate Tree (Theobroma Cacao). Much reduced.

or $3 \mathrm{in.} \mathrm{in} \mathrm{diameter.} \mathrm{They} \mathrm{are} \mathrm{dried,} \mathrm{roasted,} \mathrm{and}$ ground to form Cocoa. Finely ground, made up into a paste and flavoured, they form Chocolate. In 1871 upwards of seventeen millions of pounds of Cocoa were imported into Great Britain; upwards of seven millions being entered for home use. 
15. Natural Order.-Geraniacer. The Geranium Fanily.

Distribution. - Temperate and sub-tropical regions of both hemispheres; two genera being largely developed at the Cape of Good Hope.British genera 4, species 19.

Herbs. Flowers regular or in regular. Stamens definite, free or monadelphous. Placentas axile.

\section{(Cranes'-bills.)}

Type-Meadow Geranium (Geranium pratense). A perennial herb, with multipartits stipulate leaves, blue pedunculate regular fiowers, and benked fruits.

\begin{tabular}{|c|c|c|c|}
\hline Orgrns. & No. & Cohesion. & Adhesion. \\
\hline $\begin{array}{l}\text { Cairx. } \\
\text { sepals. }\end{array}$ & 5 & Polysejialous. & Inferior. \\
\hline $\begin{array}{l}\text { Cornlla. } \\
\text { petals. }\end{array}$ & 5 & Polypetalous. & Hypogynous: \\
\hline Stamens. & 10 & Monadelphouts. & Нуродуnоus. \\
\hline $\begin{array}{l}\text { Pistil. } \\
\text { carpels. }\end{array}$ & 5 & Syncarpous. & Superior. \\
\hline Seeds. & \multicolumn{3}{|c|}{$\begin{array}{l}\text { Two in each carpel, embryo with folded } \\
\text { cotyledons. }\end{array}$} \\
\hline
\end{tabular}

ObSERVE 5 stamens alternately shorter than the rest; in the allied genus Erodium (Stork'sbill) these are without anthers: the beak-like prolongation of the consolidated apices of the rarpels. After flowering, this beak grows out to a length sometimes of 2 or 3 inches.

Compare the slightly irregular flower of a 
Garden Gtrinium (Pelargonium) with the irregular flower of Indian Cress (Tropceolum majus). In both the calyx is spurred, the spur being free in the latter and adnate to the pedicle in the former; as may be seen on making a crosssection of the pedicle, immediately under the Hlower.

Cultivated varieties of two or three species of Cape Pelargonium are universal favourites, as are also Indian Cress (Tropceolum majus) called Garden Nasturtium (but not to be confounded with true Nasturtium, the Water-cress, belonging to the Crucifers) and the Canary-flower ( $T$. peregrinum).

Sorrel Oxalis (Oxalis acetosella,-called generally "Wood-sorrel"), with compound trifolioliste leaves, belongs to the same Natural Order. It affords an example of remarkable dimorphism in the flowers, similar to that presented by Swiet Violet (page 145). Of this dimorphism no salisfitctory ciplanation has been offered.

Sume species, as Felargonium triste and Oxalis tuberosa, have tuberous roots, which are used as food.

16. Natural Order-Polygalaceæ. The Milkwort Family.

Distribution.-Temperate and tropical regions in both hemispheres.-One British genus, species 2.

IIerbs. Flowers irregrular. Stamens 8, monadelphous. 'Type-Common Milkwort (Polygala vulgaris). A low wiry perennial herb, with alternate entire leaves, and racemose irregular flowers. 


\begin{tabular}{|c|c|c|c|}
\hline organ. & Nu. & Cohesion. & Adhesion. \\
\hline $\begin{array}{l}\text { Calyx. } \\
\text { sepals. }\end{array}$ & 5 & Polysepalous. & Inferior. \\
\hline $\begin{array}{l}\text { Corolla. } \\
\text { petals. }\end{array}$ & 3 & Polypetalous. & $\begin{array}{l}\text { Inserterl on } \\
\text { stamens. }\end{array}$ \\
\hline Stamens. & $\delta$ & Monadelphous. & Hypogynous. \\
\hline $\begin{array}{l}\text { Pistil. } \\
\text { carpels. }\end{array}$ & 2 & Synearpous. & Superior. \\
\hline Seerls. & One i & each cell, albu & inous. \\
\hline
\end{tabular}

OBSERVE the two large lateral inner sepals, called wings, which persist and enclose the fruit: the cohesion of the filaments and their adhesion to the petals, so that the latter appear to form a gamopetalous corolla: the 1-celled anthers, dehiscing by pores: the membranous hood of the stigma, apparently designed to insure self-fer. tilization. Observations upon living plants of Milkwort are wanted in order to ascertain whether inzacts take any part in the conveyance of pollen from flower to flower. It has been ascertained that Funitories, which have their anthers and stigma protected by the petals as in Milkwort, are occasionally crossed by insects.

17. Natural Order-Acermex. The Maple Family (a Tribe of the Tropical Order Sapindacex). Distribution.-Chiefly restricted to the North temperate zone of both hemispheres.-One British genus, species 2.

Trees. Leaves opposite. Stamens definite.

Type-Common Maple (Acer campestre).

A dark-green deciduous tree, with opposite 5-lobed leaves, and loose corymbose flowers. 


\begin{tabular}{|c|c|c|c|}
\hline Organs. & No. & Cohesion. & Adhesion. \\
\hline $\begin{array}{l}\text { Calyx. } \\
\text { scpals. }\end{array}$ & $5(4-9)$ & Polysepalous. & Inferior. \\
\hline $\begin{array}{l}\text { Corolla. } \\
\text { petals. }\end{array}$ & $5(4-9)$ & Polypetalous. & Hуроgynous. \\
\hline Stamens. & $8(5-12)$ & Octandrous. & Hypusynous. \\
\hline $\begin{array}{l}\text { Pistil. } \\
\text { carpels. }\end{array}$ & 2 & Syucarpous. & Superior. \\
\hline Seeds. & \multicolumn{3}{|c|}{ Solitary or in pairs, exalbuminous. } \\
\hline
\end{tabular}

The number of parts in the floral whorls is variable.

OBSERve the large hypogynous disk, and the winged fruit, called a samara.

Some species of Maple abound in a sweet juice, which is collected from the North American Sugar Maple (A. saccharinum), and boiled down into Maple sugar. The sap is obtained in spring by tapping the tree to a depth of about half an inch, and inserting a tube. The sap flows for six weeks at from two to three gallons per day. Good Maples yield an average of four pounds of sugar each season.

The soft white wood of the Sycamore Maple is used for trenchers, bowls, \&c. Maples are often incorrectly called Plane-Trees.

The Horse Chestnut (AEsculus) is an Asiatic tree, commonly planted in England for shade, belonging to another tribe of the Natural Order Sapindaceæ.

OBSERve the structure of the embryo of the exalbuminous seed of Horse Chestnut, the cotyledons being more or less connate, so that the seed looks as though it were acotyledonous. Compare also the seed of Horse Chestnut with 
the fruit of the Sweet Chestnut (Castanea). They resemble each other closely at first sight, but tile coat of the latter is a perianth, adherent to an inferior ovary. The bitter flavour of Horse Chestnut seeds is said to be corrected by adding one or two per cent. of carbonate of soda to the ground meal, and washing it until it becomes white. From $100 \mathrm{lbs}$. of the Chestnuts $60 \mathrm{lbs}$. of meal or flour may be obtained.

\section{Division. Calycifloræ.}

18. Natural Order-Celastracex. The Celastrus Family.

Distribution.-Dispersed throughout the tropical and temperate zones.-One British genus, species 1 .

Type-Common Spindle-tree (Euonymus europoens).

A deciduous glabrous shrub, with opposite undivided leaves, and small yellowish-green cymose flowers. (The only British species.)

\begin{tabular}{|c|c|c|c|}
\hline Organs. & No. & Cohesion. & Athesion. \\
\hline $\begin{array}{l}\text { Calyx. } \\
\text { sepals. }\end{array}$ & $4(5)$ & Gamosepalous. & Inferior. \\
\hline $\begin{array}{l}\text { Corolla. } \\
\text { petals. }\end{array}$ & $4(5)$ & Polypetalous. & Perigynous. \\
\hline Stamens. & $4(5)$ & Tetrandrous. & Perigynous. \\
\hline $\begin{array}{l}\text { Pistil. } \\
\text { carpels. }\end{array}$ & 4 & Syncarpous. & Superior. \\
\hline Secds. & \multicolumn{3}{|c|}{ Solitary in each cell, albuminous. } \\
\hline
\end{tabular}

OBSERve the bright orange-coloured arillus, covering the seed. The arillus is a cellular investment growing more or less over the seed as it matures, either from the funicle (the pedicle 
by which the ovule is attached to the placenta) or from the micropyle. In the Nutmeg fruit we have another good example of the arillus, in the mace which closely invests the crustaceous testa enclosing the "Nutmeg." The Nutmeg is further remarkable from its interrupted, marbled albumen; such albumen is termed ruminated. The minute embryo is at one extremity of the seed.

Charcoal is prepared from the wood of the Spindle tree, for the use of artists.

19. Natural Order-Aquifoliacex. The Holly Family.

Distribution.-Mosu numerous on the mountain slopes of South America, with a few representatives in the Tropics and Temperate Zone of the Old Wurld. But one species in tropical Africa and Australia respectively.-One British genus, species 1.

Type-Common Holly (Ilex aquifolium).

A much-branched evergreen tree, with alternate coriaceous shining prickly leaves, and small white clustered axillary flowers. (The only British species of the Family.)

\begin{tabular}{|c|c|c|c|}
\hline Organs. & No. & Cohesion. & Adhesinn. \\
\hline $\begin{array}{l}\text { Salyx. } \\
\text { sepcels. }\end{array}$ & 4 & Gamosepalous: & Inferior. \\
\hline $\begin{array}{l}\text { Corolla. } \\
\text { petals. }\end{array}$ & 4 & $\begin{array}{l}\text { Gamo- or poly- } \\
\text { petalous. }\end{array}$ & Perigynous. \\
\hline Stamens. & 4 & Tetrandious. & $\begin{array}{l}\text { Perigymous or } \\
\text { epipetalous. }\end{array}$ \\
\hline $\begin{array}{l}\text { Pistil. } \\
\text { carpels. }\end{array}$ & 4 & Syz:arjous. & Superior. \\
\hline Secds. & \multicolumn{3}{|c|}{ One in ear h bony cell, albuninous. } \\
\hline
\end{tabular}


'The white wood of the Holly is used in Tunbridge marquetry ware as the base into which patterns are inlaid. Birdlime is prepared from the bark.

'The leaves of a South American Holly (I. paraguayensis) are extensively used as tea, under the name of Maté or Paraguay tea.

20. Natural Order-Rhamnaceæ. The Buckthorn Family.

Distributron.-Tropics and temperate zones in both hemispheres.-One British genus, species 2.

Shrubs. Stamens definite, opposite to the petals.

'Jype-Alder Buckthorn (Rhamnus Frangula).

A deciduous nearly glabrous shrub, with alternate undivided leaves, and inconspicuous axillary flowers.

\begin{tabular}{|c|c|c|c|}
\hline Organs. & No. & Cohesion. & Adhesion. \\
\hline $\begin{array}{l}\text { Calyx. } \\
\text { sepals. }\end{array}$ & $5(4)$ & Gamosepalous. & Inferior. \\
\hline $\begin{array}{l}\text { Corulla. } \\
\text { petals. }\end{array}$ & $5(4)$ & Polypetalous. & Perigynous. \\
\hline Stamens. & $5(4)$ & Pentandrous. & Perigynous. \\
\hline $\begin{array}{l}\text { Pistil. } \\
\text { carpels. }\end{array}$ & $3-5$ & Syncarpous. & Superior. \\
\hline Seeds. & One i & I each cell, \{,lbu & ninous. \\
\hline
\end{tabular}

Compare the flowers of Buckthorn and Spindletree. In the former the stamens are opposite to the petals, in the latter alternate with them. The number of parts in the floral whorls is apt to vary.

The unripe berries of Common Buckthorn ( $R$. catharticus) afford a yellow dye ; when ripe, they yield (with alum) "sap-green." "French-berries" are procured from $R$. infectorius. The drupes of exotic species of $Z i$ iyphus are wholesome, and are 
known as "jujubes." The fruit of $Z$. Lotus of North Africa is stated to have been eaten by an ancient race, called, on that account, Lotophagi. The wood of Rhamnus Frangula yields a charcoal used for the finer kinds of gunpowder.

21. Natural Order-Leguminosæ. The Leguminous Family.

Distribution.-A very large Natural Order, numerous in every quarter of the globe. The extra-European Tribes, Cæsalpinieæ and Mimoseæ, are chiefly tropical.-British genera 18, species 69.

Shrubs or herbs. Flowers papilionaceous. Stamens 10, monadelphous or diadelphous. (As to the British species.)

This very large and irnportant Order requires illustration by two Types; one to represent the genera with irregular flowers and imbricate petals, the other those with regular flowers and valvate petals. The former only are represented in Britain. They are grouped under the Tribe Papilionacecethe Pea-flower Tribe, of which we may take as

Type-Garden Pea (Pisum sativum).

A weak climbing annual herb, with alternate stipulate compound leaves ending in tendrils, and irregular (papilionaceous) flowers.

\begin{tabular}{|c|c|c|c|}
\hline Organ. & No. & Cohesion. & Adhesion. \\
\hline $\begin{array}{l}\text { Calyx. } \\
\text { sepals. }\end{array}$ & 5 & Gamosepalous. & Inferior. \\
\hline $\begin{array}{l}\text { Corolla. } \\
\text { petals. }\end{array}$ & 5 & Polypetalous. & Perigynous. \\
\hline Stamens. & 10 & Diadelphous. & Perigynous. \\
\hline $\begin{array}{l}\text { Pistil. } \\
\text { carpels. }\end{array}$ & 1 & Apocarpous. & Superior. \\
\hline Seeds. & i & al, exalbumino & \\
\hline
\end{tabular}


OBळERVE the relation of the petals of the irregular corolla to each other. There is a large

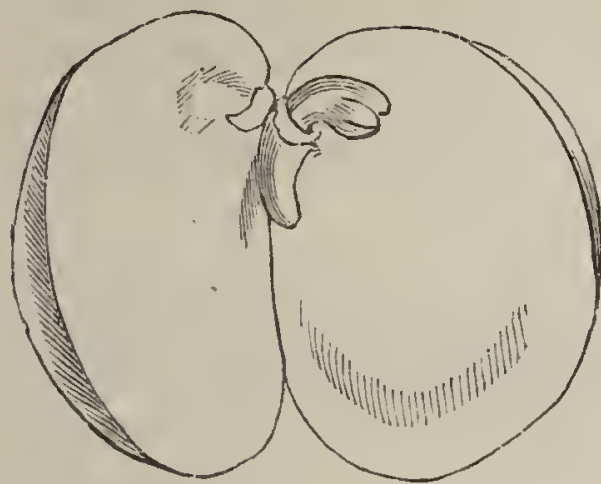

Frg 96. Emliryo of Pea with the cotyledous laid open, showing the curved plumule and radicli.

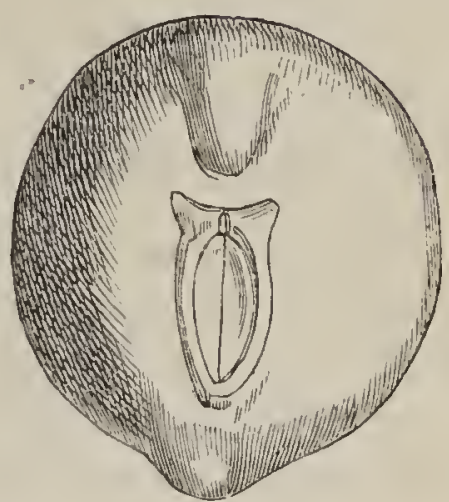

Fia 97. Seerl of same before removal of the testa, showing the lilum and ridge ahove indieating the position of the radicle inside.

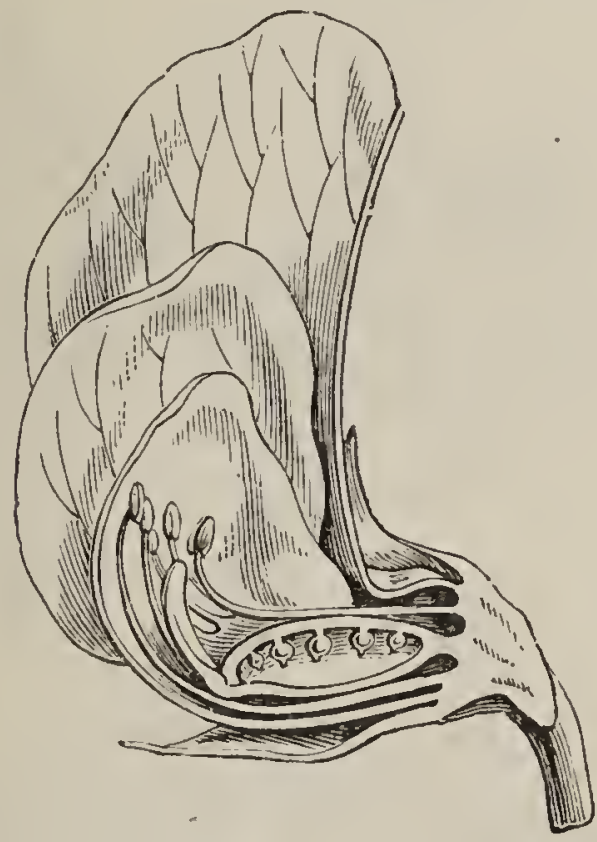

Fra. @S. Vertical section of flower of Garden Pea.

upper petal which embraces the others in xstivation: this is the standard. Two lateral petals are 
called the wings, and two, more or less united by their lower margins, form the keel, which eneloses the stamens. From a fancied resemblance to a butterfly, this form of corolla has been called papilionaceous. In the Tribe Crsalpinieæ, not represented in Britain, the upper petal is inside in the bud.

Observe, also, the spinose branches, leaves reduced to thorns, and bipartite calyx of Common Furze (Ulex europceus): leafy stipules substituting true leaves in Yollow Pea (Lathyrus aphaca): petals often colering by their claws in

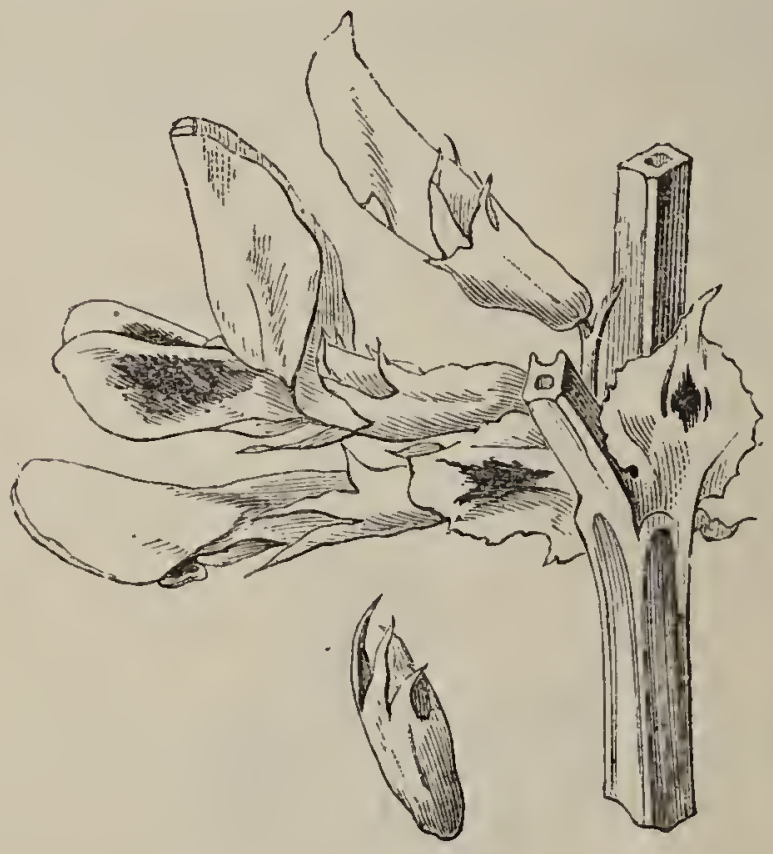

Fig. 29. Flowers of Bean.

Clover (Trifolium): the peduncles of Subterranean Clover ( $T$. subterraneum), which curve towards the ground after flowering, emitting short fibres. 
In earth-nut (Arachis hypogoea) the fruit is ripened underground.
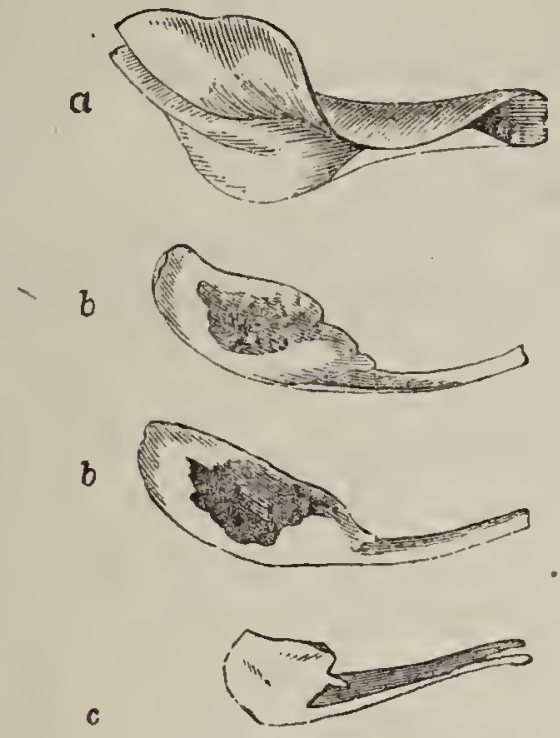

F10. 100. Patals of Bean: a stanclard (vexillum), bu wings :ala\}, c coherent petals of keel (carina).

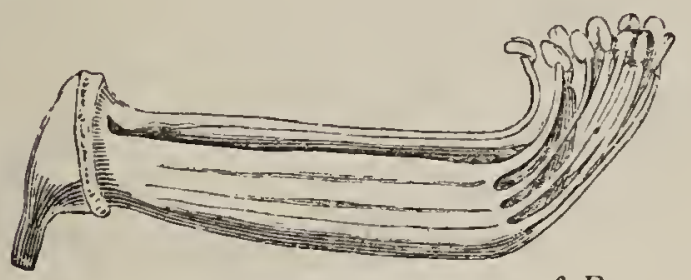

(. 101. Diadelphous stamens of Pea.

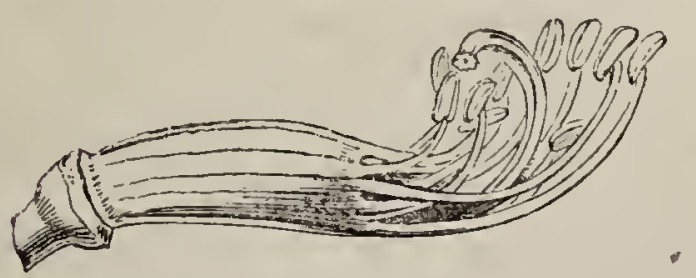

Fig. 102. Monadelphous stamens of Broom.

Comparf the stamens of Pea [diadelphous]; Broom (Sarothamnus) or Furze (Ulex) [mon- 
adelphous]; and Judas-tree (Cercis) [free and decandrous]. Compare also the fruits (legumes) of Pea; Medick (Medicago) [spirally twisted]; Astragalus [partially 2-celled by infolding of the dorsal suture]; Bird's-foot (Ornithopus) [indehiscent and jointed, called a loment]; Cassia fistula [indehiscent, with numerous spurious tranverse dissepiments developed from the endocarp] ; Tonquin Bean (Dipteryx) [indehiscent and drupaceous]; Pterocarpus [winged, 1-seeded and indehiscent].

The Natural Order derives its name Leguminose from the characteristic form of its fruit, called a legume. T'he legume is normally monocarpellary (of 1-carpel), dry and dehiscent by both sutures (ventral and dorsal), but the examples just given show that the typical form of fruit is departed from in many genera.

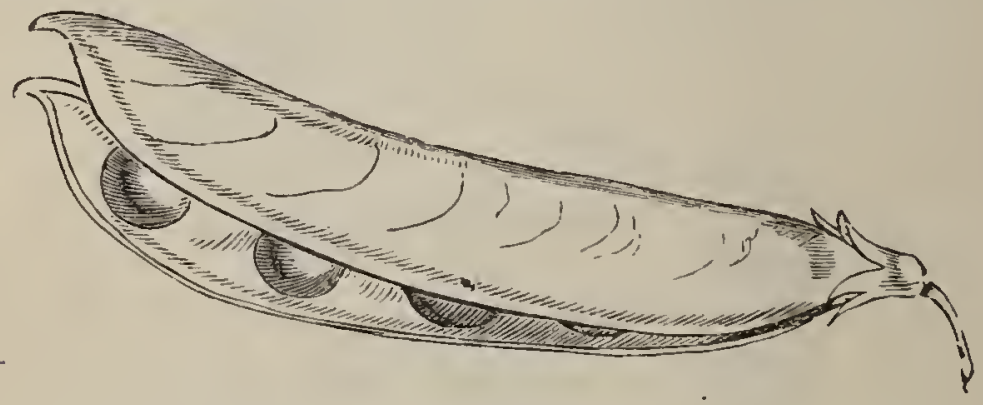

Fig. 103. Fruit (legume) of Garden Pea.

But a few of the numerous species serviceable to man can be noticed here.

Of Timber trees, the more important are the well-known cabinet Rosewoods (South American species of Dalbergia) and the Locust-tree (Hymencea) of tropical South America, the latter 
affording a very tough and close-grained wood. The heart-roood of the Laburnum is coloured dark brown, contrasting with the pale sap-wood. West Indian Ebony (Brya) and the streaked wood of the Tamarind (Tamarindus) are used in cabinet work.

Of Dyes, we have Indigo, obtained by decom. posing several species of Indigofer $a$ in water. The colouring matter settles to the bottom, is dried and cut up into cakes, 135,901 hundredweights of this important dye were imported in 1871. Red Sanders-wood (Pterocarpus santalinus), a reddishbrown dye, used for woollen cloths; Logwood (Homatoxylon campechianum), one of the best deep red and black dyes, imported from Central America and the West Indies, in 1868 to the extent of 35,067 tons; Sappan-wood (Casalpinia sappan); Brazil-wood (Ccesalpinia); and Camwood (Baphia), used for Bandana handkerchiefs.

Of Gums, Resins, \&c.-Tragacanth, a viscid gum which exudes from species of Astragalus in Asia Minor, due to an altered condition of the cellular tissue of the stem; Balsam of Peru (Myrospermum Pereirce), used in medicine ; Copal, used in varnishes-the species affording it are not well determined.

Spanish juice is the sweet extract of Liquoriceroot (Glycyrrhiza glabra and G. echinata), evaporated to dryness; and Tamarinds, as imported, are the pulp of the fruit of Tamarindus, preserved in syrup.

Of Food plants we have the Pea (Pisum); Bean (Vicia faba); Lentils (Ervum), cultivated by ancient nations; French Beans (Phaseolus 
vulgaris); Scarlet Runner (P. coccineus); Gram (Cicer arietinum); and Ground-nuts (Arachis hypogcea) ; the last widely grown in warm countries. The seeds of some species are very poisonous. Those of Laburnum have proved fatal to children. The Ordeal Beans of West Africa are the seeds of Physostigma venenatum. The seeds of Abrus precatorius, called "Crabs'-eyes," are strung together for necklaces. They are nearly uniformly one grain each, and are used in India by druggists and jewellers as weights. The seed of the Carob (Ceratonia) is the original of the carat of jewellers. The legurnes, which contain much sweet pulp, are imported for cattle-feeding.

As type of the Tribe Mimoseæ, principally tropical and Australian, we may employ

Broad-winged Acacia (Acacia plaptyptera).

It differs from the Pea-flower type in its regular corolla with valvate æstivation, and numerous stamens.

In a large number of Australian species of Acacia the leaves are reduced to phyllodes: the blade of the leaf,. which is developed in some of the species, is usually very much divided.

Some species of Mimosa (especially $M$. pudica) re remarkable for the great degree of "irritability" exhibited by the leaflets when touched or shaken. This irritability is but an extreme case of the condition (called "sleep") common to many Leguminosæ, the leaves of which fold together in the evening, and remain closed until the next morning.

Gum Arabic is afforded by African species of 
Acacia. It was formerly brought from Arabia or Egypt, but is now chiefly imported from West Africa. Catechu, an astringent used by tanners, is obtained by boiling the heart-wood of $A$. catechu, an East Indian tree.

The tree called Acacia, commonly planted in Fngland, does not belong to the genus Acacia. It is a North American Robinia, and belongs to the Pea-flower tribe.

22. Natural Order-Rosacer. The Rose Family.

Distribution. - Widlely dispersed throughout both hemispheres, though specially affecting the North Temperate Zone.-British genera 17, species 43.

Shrubs or herbs. Flowers regular. Stamens indefinite (usually 4 in Alchemilla and Sanguisorba). Pistil apocarpous (spuriously syncarpous when the calyx tube is adherent to the ovary).

Type-Blackberry Rubus (Rubus fruticosus) A trailing prickly shrub, with stipulate digi. tite leaves, and panicled regular flowers.

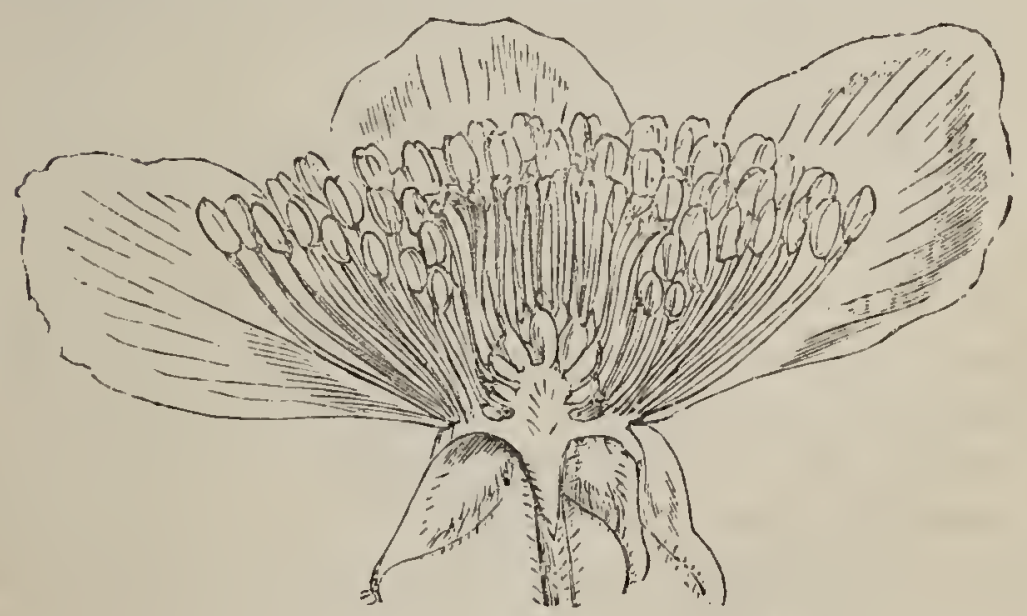

Fıc. 104. Vertical section of flowex of Blackberry Ru'bus 


\begin{tabular}{|l||r|l|l|}
\hline \multicolumn{1}{|c|}{ Organ. } & No. & \multicolumn{1}{c|}{ Cohesion. } & \multicolumn{1}{|c|}{ Adhesion. } \\
\hline $\begin{array}{l}\text { Calyx. } \\
\text { sepals. }\end{array}$ & 5 & Gamosepalous. & Inferior. \\
\hline $\begin{array}{l}\text { Corolla. } \\
\text { petals. }\end{array}$ & 5 & Polypetalous. & Perigynous. \\
\hline \begin{tabular}{l} 
Stamens. \\
\hline $\begin{array}{l}\text { Pistil. } \\
\text { carpets. }\end{array}$
\end{tabular} & $\infty$ & Polyandrous. & Perigynous. \\
\hline \begin{tabular}{l} 
Seeds. \\
\hline
\end{tabular} & Solitary in each carpel, exalbuminous. \\
\hline
\end{tabular}

The deviations from this type are so important that some botanists divide the Order into four distinct Orders. These may be more correctly regarded as Tribes of one Order. The four Tribes are :

Rosece. Blackberry (Rubus) as type.

Drupacece. Cherry (Prunus) as type, with a solitary carpel.

Pomacece. Apple (Pyrus) as type, with the "calyx-tube" adnate to the ovary.

Sanguisorbece, Burnet Sanguisorb (Sanguisorba offinalis) as type, with monochlamydeous, sometimes unisexual, flowers ; the calyx-tube investing the achene, but not adherent to it.

The species of this Order agree in their perigynous stamens, which are usually indefinite; the polypetalous corolla (absent in Sanguisorber), prone to become "doukle" at the expense of the stamens, as in the Ranunculus Family; and the essentially apocarpous fruit. In Pomaceæ, represented by the Apple, the fruit is inferior and apparently syncarpous; but if it be cut across it will be seen that the carpels scarcely cohere to each other, though pressed and bound together by 
the succulent enlargement of the so-called calyxtube. It is therefore spuriously syncarpous.

OBserve the passage of branches into spines in the Hawthorn (Cratogus) and Blackthorn (Prunus): the prickles of Rose and Blackberry: the epicalyx of Blackberry, Strawberry (Fragaria), and some other Rosex, resembling an outer row of sepals: the definite stamens of

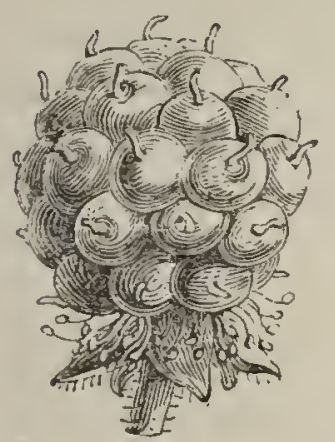

Fra 105. Fruit of Blackberry Frg. 106. Single drupel of same Rubus.

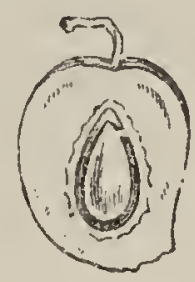

Alchemil (Alchemilla) and Burnet Sanguisorb, the former with 1-celled anthers.

Compare the number of carpels and form of fruit in Cherry [1 carpel, fruit a drupe]; Alciemil [1 carpel, fruit an achene enclosed by the froe calyx-tube]; Strawberry [indefinite achenes upon

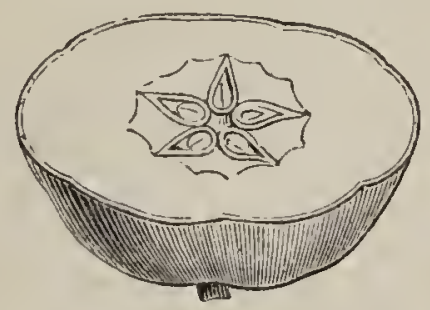

Fra 107. Transverse section of an Apple. 
a surculent rounded receptacle]; Blackberry anis Rasplerry [numerous drupels]; Meadow Spiræa [several, about seven, follicles]; Rose [numernus free achenes enclosed in a concare succulent calyxtube or receptacle]; and Apple [5 bony carpels adnate to the calyx-tube].

The Natural Order Rosaceæ furnishes our most valuable orchard trees, as well as many of our most beautiful garden flowers.

Species affording useful fruits are Apple, Pear (Pyrus); Quince (Cydonia) ; Medlar (Mespitus) ; Almond, Peach, Nectarine (A mygdalus) ; Cherry, Apricot, Plum (Frumus); Loquat (Eriobotrya); Strawberry (Fragaria); Raspberry and Blackberry (Rubus).

Some of the Order, as Almond, Peach, and the species of Prumus, contain prussic acid, the vapour of which, given off from a crushed leaf of Garden Laurel ( $P$ '. lauro-cerasus) under an inverted tumbler, will soon destroy the life of an insect. Owing to the presence of this acid, tha Uil of Bitter Almonds is a virulent poison.

From the petals of sweet-scented species of lose the Attar or Otto of Rose is obtained. 100,000 Rose-flowers are said to be required to yield three drachms of the pure Attar. ${ }^{*}$ It is consequently very costly, and is commonly adulterated with an Indian Grass Oil.

Mossy galls, called Rose Bedeguars or 'Robin Redbreast's Pincushions,' are frequent upon the Dog Rose (Rosa canina) in autumn, produced by

* From 28 to $40 \mathrm{lbs}$, of the petals in dry weather, or about half the quantity when moist, yield 1 drachm of Attar. 
the puncture of species of Cynips. If kept until the following spring, the young Cynips will be produced, also species of Ichneumon, which prey upon the Cynips.

The fruit-bearing species in cultivation afford a good opportunity of observing the different modes and effects of grafting. 'To secure the success of a graft it is essential that the cambium-layers of the graft and stock should be in contact, and the cut surface protected from evaporation. A section through an old graft shows, notwithstanding the complete union of the tissues of the graft and stock, that each retains the peculiar character of its own wood. This is particularly striking when the woods are of different colours or shades of colour, as when the Peach is grafted upon a Plum stock.

Bear in mind that the Garden Laurel, with large, shining leaves, and the Portugal Laurel, both very common garden shrubs, are species of Prunus, and have nothing to do with the true (Victor's) Laurel, belonging to the exotic Order Lauracex, a Family of Monochlanydex, with the anthers dehiscing by valves, like those of the liarberry.

23. Natural Order--Onagracex. The Ginothera Family.

Distribution. - Temperate Zone of both hemispheres; less numerous between the Tropics.-British genera 4, species 13 .

Herbs. Stamens 2, 4, or 8 . Ovary inferior.

Type-Great Epilobe (Epilobium hirsutum). (Willow-herb.)

A tall perennial herb, with clasping lanceo- 
late undivided leaves, and rose-coloured regular flower's.

\begin{tabular}{|l||r|l|l|}
\hline \multicolumn{1}{|c|}{ Organ. } & No. & \multicolumn{1}{c|}{ Cohesion. } & \multicolumn{1}{c|}{ Adhesion. } \\
\hline $\begin{array}{l}\text { Calyx. } \\
\text { sepals. }\end{array}$ & 4 & Gamosepalous. & Superior. \\
\hline $\begin{array}{l}\text { Corolla. } \\
\text { petals. }\end{array}$ & -4 & Polypetalous. & Perigynous. \\
\hline \begin{tabular}{ll} 
Stamens. \\
\hline $\begin{array}{l}\text { Pistil. } \\
\text { carpels. }\end{array}$
\end{tabular} & \begin{tabular}{ll} 
Octandrous. \\
\hline Seeds.
\end{tabular} & \begin{tabular}{l} 
Pericynous. \\
\hline Indefinite, exalbuminous.
\end{tabular} \\
\hline
\end{tabular}

OBSERve the dimerous symmetry of Enchanter's Nightshade (Circcea), the parts of the flower being in twos: the coloured calyx of Fuchsia: the expansion of the flowers, in the evening only, of Common QEnothera (Enothera biennis), hence called Evening Primrose : the silky coma surrounding the top of the seeds of the Epilobes (Willow-herbs).

24. Natural Order-Lythraceæ. The Lythrum Family.

Distribution.-Tropical and temperate regions of both hemispheres; most numerous in America. -British genera 2, species 3.

Herbs. Flowers regular. Stamens 6 or 12. Ovary superior.

Typo-Spiked Loosestrife (Lythrum salicaria). A perennial erect herb, with opposite or verticillate entire leaves, and terminal spicate rose or purple flowers. 


\begin{tabular}{|c|c|c|c|}
\hline Orqans. & No. & Cohesion. & Adhesion. \\
\hline $\begin{array}{l}\text { Calyx. } \\
\text { sepa?s. }\end{array}$ & 6 & Gamosepalous. & Inferior. \\
\hline $\begin{array}{l}\text { Corolla. } \\
\text { petals. }\end{array}$ & 6 & Polypetalous. & Perigynous. \\
\hline Stanens. & 12 & Dodecandrous. & Perigynous. \\
\hline $\begin{array}{l}\text { Pistil. } \\
\text { carpels. }\end{array}$ & 2 & Syncarpous. & Superior. \\
\hline Seerds. & Num & ous, exalbum & ous. \\
\hline
\end{tabular}

Observe the six teeth alternating with the free extremities of the coherent sepals, so that there

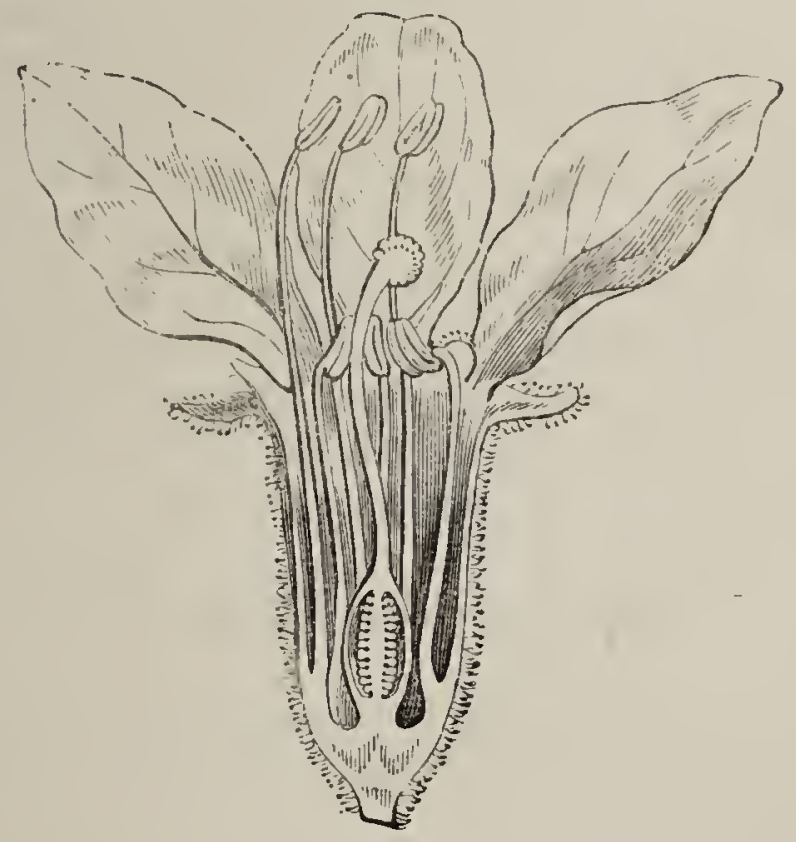

F10. 108. Vertical section of flower of Spilied Loosestrite.

appear to be twelve sepals cohering to form the calyx: the relative length of stamens and style N 2 
in the fluwers of different plants of Spriked Loosestrife. Mr. Darwin points out that the stamens in this species are of three lengths-long, medium, and short. But two lengths only occur on the same plant, there being two sets of six in each flower. The styles also are of three corresponding lengths-long, medium, and short; and as they are never associated with stamens of corresponding length, we have three forms of flower:-No. 1, with short and medium stamens, and long style; No. 2, short and long stamens, and medium style; and No. 3, with medium and long stamens, and short style. Mr. Jarwin's experiments indicate that it is of advantage to the plant to have the stigma fertilized by pollen from stamens of corresponding length, which necessarily involves the aid of insects, as these are borne not only by a different flower, but also upon a different plant.

Henna, used by Egyptian ladies to dye their nails and the palms of the hand a reddish-brown colour, is obtained from the leaves of Lawsonice inermis. The nails of mummies have been found stained in this way.

25. Natural Order-Cucurbitacex. The Gourd Family.

Distuibution.-CTropical and warmer regions of both the Old and New World.-One British genus, species 1 .

Type-Common Bryony (Bryonia dioica).

A climbing perennial herb, with palmatelylober leaves, extra-axillary tendrils, and dicecious towers. (The only British species.) 


\begin{tabular}{|c|c|c|c|}
\hline Organ. & No. & Cohesion. & Adhesion. \\
\hline $\begin{array}{l}\text { Calyx. } \\
\text { sepals. }\end{array}$ & 5 & Gamosepalous. & Superior. \\
\hline $\begin{array}{l}\text { Corolla. } \\
\text { petals. }\end{array}$ & 5 & Ganopetalous. & Perigynous. \\
\hline s, Stamens. & 3 & Triandrous. & Perigynous. \\
\hline o, I'istil. & 0 & & \\
\hline q, Stamen & 0 & & \\
\hline $\begin{array}{l}\text { q, Pistil. } \\
\text { curpels. }\end{array}$ & 3 & Synearpous. & Inferiur. \\
\hline
\end{tabular}

OBsenve the tendrils, often more or less extra-axillary, regarded as modified leaves of shoots, the internodes of which are undeveloped : the stamens, the anther of one of which is 1-celled, the others being 2-celled. The anthercells are remarkably sinuous in Bryony and many other genera of the Order, being twisted like the letter $0 \Omega$.

The Cucurbitaceæ are mostly tropical. Amongst them are several species extensively grown for the sake of their fruits, as the Gourd, Pumpkin, Cucumber, Melon, and Water-Melnn.

The firm outer layer of the pericarp is often hollowed out, as in the Bottle-Gourd (Lagenaria), and used as a domestic utensil, or ornamented with figures burnt upon the surface. The fruit of the Gourd sometimes attains an enormous size. one raised in Norfolk, in 1846, weighed 196 pounds. The fibrous inner layer of the pericarp of the Towel-Gourd (Luffa agyptiaca) is used as 
sponge and gun-wadding. Many species are intensely bitter, and some are dangerously poisonous, as the Colocynth (Citrullus colocynthis) and Squirting Cucumber (Momordica Elaterium, L.); the latter so called because the fruit, when quite ripe, separates suddenly from the peduncle, and the sides, forcibly contracting, squirt out the contained pulp with considerable force.

26. Natural Order-Crassulacex. The Crassula Family.

Distribution.-Temperate and tropical regions of both hemispheres. Numerous in South Africa. - British genera 4, species 12.

Herbs with fleshy leaves. Flowers regular. Pistil apocarpous, or nearly so. Carpels 3 or more.

$$
\text { Type-Biting Sedum (Sedum acre). }
$$

(Stonecrop.)

A procumbent perennial herb, with small succulent leaves, and terminal cymes of yellow flowers.

\begin{tabular}{|c|c|c|c|}
\hline Organ. & No. & Cohesion. & Adhesion. \\
\hline $\begin{array}{l}\text { Calyx. } \\
\text { sepals. }\end{array}$ & 5 & Gamosepalous. & Inferior. \\
\hline $\begin{array}{l}\text { Corolla. } \\
\text { petals. }\end{array}$ & 5 & Polynetalous. & Perigynous. \\
\hline Stamens. & 10 & Decandrous. & Perigynous. \\
\hline $\begin{array}{l}\text { Pistil. } \\
\text { curpels. }\end{array}$ & 5 & Synearpous. & Superior. \\
\hline Seeds. & \multicolumn{3}{|c|}{ Several in each follieular carpel. } \\
\hline
\end{tabular}


Observe the excessive succulence or the foliage, characteristic of the Order, and the nearly apocarpous condition of the pistil.

In drying specimens of this Family for the herbarium, it is often necessary, owing to their succulence, to scald them, or to steep them in a solution of corrosive sublimate, before putting them in drying paper. This prevents the leaves from falling off.

Houseleek (Sempervivum), common on cottageroofs, is subject to a monstrous condition of the stamens; some of the anthers, occasionally all of them, bearing ovules.

The leaves of Bryophyllum calycinum, a greenhouse plant, when placed on damp soil readily produce young plants from buds originating in the notches (crenatures) of the margin. This is supposed to illustrate the development of ovules, which are, normally, buds borne upon the margin of a carpellary leaf.

27. Natural Order-Ribesiaceæ. The Currant Family.

Distribution.-North Temperate Zone and the Andes of South America.-One British genus, species 4.

Shrubs. Flowers regular. Stamens 4 or 5 . Pistil syncarpous, monogynous. Placentas parietal.

Type-Gooseberry Ribes (Ribes grossularia).

(Common Gooseberry.)

A prickly deciduous shrub, with small droop ing greenish flowers, and baccate fruit. 


\begin{tabular}{|c|c|c|c|}
\hline Organ. & No. & Cohesion. & Adhesion. \\
\hline $\begin{array}{l}\text { Calyx. } \\
\text { sepals. }\end{array}$ & 5 & Gamosepalous. & Superior. \\
\hline $\begin{array}{l}\text { Corolla. } \\
\text { petals }\end{array}$ & 5 & Polypetalous. & Perigynous. \\
\hline Stamens. & 5 & Pentandrous. & Perigynous. \\
\hline $\begin{array}{l}\text { Pistil. } \\
\text { curpels. }\end{array}$ & 2 & Syncarpous. & Inferior. \\
\hline Seeds. & Indefi & ite, albmminous & parietal. \\
\hline
\end{tabular}

Observe the prickles usually immediately underneath the leaves of Gooseberry, in aspect and position recalling the spines of Barberry, (page 133). In Gooseberry, however, they are. merely epidermal appendages, analogous to bristles and hairs.

Black and Red Currants belong to the same genus as Gooseberry, but the dried Currants of shops are the fruit of a small-fruited variety of the Grape-vine (Vitis vinifera).

28. Natural Order-Saxifragaces. The Saxifrage Family.

Distribution.-Temperate Zone and cooler inter-tropical regions of both hemispheres.-British genera 4, species 19.

Herbs. Flowers regular. Stamens definite. Pistil syncarpous, styles 2 or more.

Type - Meadow-Saxifrage (Saxifraga granulata).

A small perennial herb, with a rhizome bearing minute granular bulbs, erect stem, and terminal white flowers. 


\begin{tabular}{|c|c|c|c|}
\hline - organ. & No & Cohesion. & Adhesion. \\
\hline $\begin{array}{l}\text { Calyx. } \\
\text { sepals. }\end{array}$ & 5 & Gamosepalous. & Half suneriur. \\
\hline $\begin{array}{l}\text { Corolla. } \\
\text { petuls. }\end{array}$ & $\begin{array}{l}5 \\
5\end{array}$ & Polypetalous. & Perigynous. \\
\hline Stamens. & 10 & Decandrous. & Perigynous. \\
\hline $\begin{array}{l}\text { Pistil. } \\
\text { curpels. }\end{array}$ & 2 & Syucarpous. & Half inferior. \\
\hline Seeds. & do & ite, albumino & \\
\hline
\end{tabular}

Observe the glandular radical leaves of Sundew (Drosera). Both the glands and the blade of the leaf exhibit an obscure "irritability," closing over and clasping small insects which way happen to stick to the viscid tips of the former. An allied American herb, the "Venus' Fly-trap" (Dioncea nuscipula), exhibits this irritability in a much higher degree, the two terminal lobes of the radical leaves clasping together instantaneously when any one of the three short bristles on the middle of either of the lobes is touched.

Observe, also, Hydrangea hortensis in cultivation, showing enlargement of the lobes of the calyx at the expense of the essential organs. The pale or reddish colour of the flowers passes into a blue tint in a soil containing oxide of iron.

29. Natural Order-Umbelliferæ. The Umbellate Family.

Distribution.-Most numerous in Southem Europe and temperate Asia, though with many species in North America, cooler inter-tropical regions, and the South Temperate Zone.--British genera 37 , species 57 . 
Herbs. Flowers umbellate. Stamens 5, epigynoris. Styles 2.

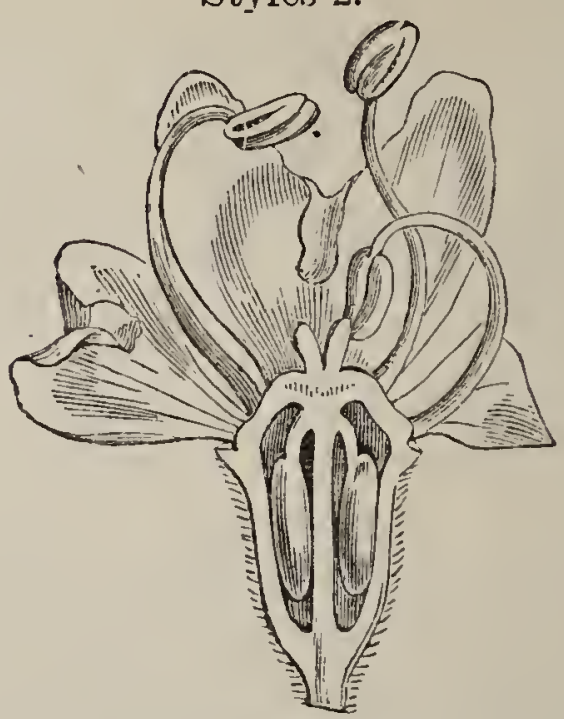

Fro. 109. Vertical section of flower of Common Heracleum, showing the bilocular ovary, with one pendulous ovule in each cell.

Type-Common Heracleum (Heracleum sphondylium).

\section{(Cow Parsnip.)}

A coarse erect hairy herb, with fistular stem, much-divided leaves with dilated sheathing petioles, and small white flowers in terminal compound umbels.

\begin{tabular}{|c|c|c|c|}
\hline Organ. & No. & Cohesion. & Adhesion. \\
\hline $\begin{array}{l}\text { Calyx. } \\
\text { sepals. }\end{array}$ & 5 & Gamosepalous. & Superior. \\
\hline $\begin{array}{l}\text { Corolla. } \\
\text { petals. }\end{array}$ & 5 & Polypetalous. & Epigynous. \\
\hline Stamens. & 5 & Pentandrous. & Epigynous. \\
\hline $\begin{array}{l}\text { Pistil. } \\
\text { carpels. }\end{array}$ & 2 & Synzarpous. & Inferior. \\
\hline Seeds. & & $\begin{array}{l}\text { each carpel, } \\
\text { minou }\end{array}$ & adulous, albu \\
\hline
\end{tabular}


From the constant use marle of characters based upon the structure of the fruit in this large and well-marked Natural Order, it is necessary to levote some careful attention to it. It is always inferior, and consists of 2 carpels, applied face to face. The entire fruit is termed a cremocarp, each of the carpels a mericarp. The mericarps are popularly called "seeds," as Caraway-seeds, \&c. You will, of course, note that each mericarp consists of seed and pericarp.

The line of union of the two mericarps is called the commissure. The pericarp is frequently marked with ridges: of these ridges, 10 are primary, viz. 5 answering to the lines of union of the $\tilde{5}$ sepals which form the calyx, and 5 to the nidribs of the same. The former, or sutural ridges, are opposite to the petals; the latter, or carinal ridges, are opposite to the stamens. These ridges are disposed in such a way that ench mericarp bears 5 : on one mericarp 3 carinal and

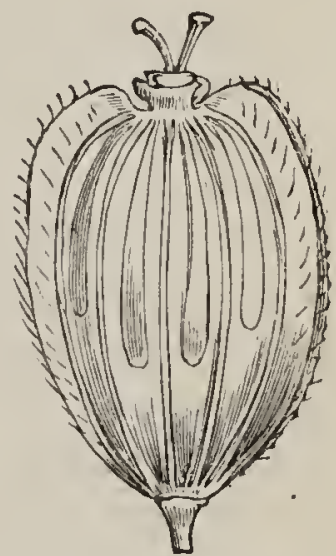

Fig. 110. One of the mericarps of the fruit of Common Heracleum, seen from the back, slowing four vittie.

2 sutural ridges; on the other, 2 carinal and 3 sutural ridges.

Secondary ridges rise, sometimes, in the interstices of the primary ridges:

Figure 111 represents a cross section of one of the mericarps of Cow-Parsnip. The structure of the fruit cannot be made out satisfactorily without examining it thus cut across. Embedded in the substance of the thin pericarp, longitudinal 
canals often occur, containing essential oil. These are the vitio. They are easily seen in Cow-

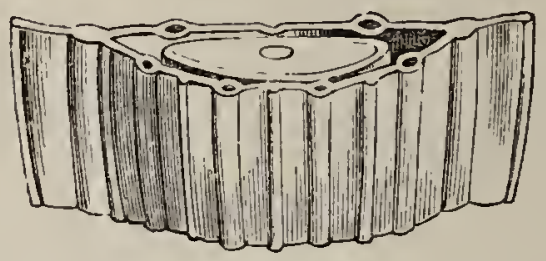

Eıg. 111. Transverse section of same, showing the ridges and vittse of the pericarp, also the embryo surrounded by albumen.

Parsnip, especially on the inner face (commissure) of a ripe mericarp. They are club-shaped, and reach more than half-way from the top of the carpel.

Observe the limb of the calyx, reduced to a rim (obsolete), or sometimes appearing as small teeth : the corolla, which is often irregular, especially in the outer flowers of an inflorescence ; the petals directed from the centre of the umbel being larger, recalling the relation of the ray and disk florets of Compositæ (page 201). The apices of the petals are often inflexed.

In respect of the leaves, compare IIydrocotyle, with orbicular peltate leaves: Eryngo, very stiff and spinous leaves: Lesser Helosciad, submerged leaves, with capillary segments: Buplever (Bupleurum), with entire leaves, in Hare's-ear Bup. lever perfoliate ; in some other species of Buplever the leaf is reduced to a phyllode: the finelydissected leaves of Fennel (Foniculum): and succulent, dissected leaves of Samphire (Crithmum).

Compare, in respect of the inflorescence, Hydrocotyle or Pennywort, with few-flowered simple 
umbele: Larger Astrantia, with bracts of the partial umbels coloured, and as long, or longer, than the flowers: Eryngo, with capitate (sessile) flowers and large prickly involucre: Celery Apium and Helosciad, with lateral umbels, owing to the buds immediately below the umbels developing shoots which overtop them, as in Lesser Senebiera.

Compare, also, fruits of Sanicle, covered with stout hooked prickles, and crowned with 5 prickly calyx-teeth: Astrantia, with plaited toothed ridges and distinct calyx-lobes, vittre 0 : Carrot, with setulose primary and prickly secondary ridges: Scandix, with a long beak, vittæ 0: Prongos, winged primary ridges: Laserpitium, winged secondary ridges, the primary being obsolete. With respect to the form of the seed, compare Cow-Parsnip (seen in cross section), with the face towards the commissure flat: Wild Chervil, with the same face furrowed: and Coriander (cut vertically), with the upper and lower ends incurved. Upon these characters, derived from the face of the seed, subordinal divisions have been based.

Although the Order includes many valuable esculent plants, yet so many species are dangerous, that Umbellifers generally are regarded as suspicious. Some, which are harmless under cultivation, are poisonous in the wild state, as Celery, which is only wholesome when blanched, by being deprived of light, which is necessary to the development of its poisonous principle.

Amongst the useful species are Carrots, Parsnips, Skirrets, Eryngo, Spignel (root); Archangel, Celery, Fennel, Parsley, Samphire (stem or 
herbage); Caraways, Corianders, Dill, Aniso, Cumin (fruit).

The root of Spignel (Meum), called Baldmoney, is chewed in the Highlands.

Arracacha, a native of the South American Andes, affords a large, fleshy, esculent root, the cultivation of which has hitherto failed in Europe.

Of our British species, Hemlock (Conium, maculatum), distinguished by its spotted stem and mousc-like smell; Cowbane (Cicuta virosa); and Hemlock Enanth (Enantice crocata) are virulent poisons. Hemlock was the State poison of Athens, by which Socrates was put to death.

30. Natural Order-Araliaceæ. The Aralia Family.

Distribution.--Principally inter-tropical in both hemispheres, with several outliers in the temperate zones.-One British genus, species 1.

Type-Common Ivy (Hedera helix).

A climbing evergreen shrub, with coriaceous, shining leaves, and incolspicauus, umbellate flowers. (The only British species.)

\begin{tabular}{|c|c|c|c|}
\hline Organ. & No. & Cohesion. & Adhesion. \\
\hline $\begin{array}{l}\text { Calyx. } \\
\text { sepals. }\end{array}$ & 5 & Gamosepalous. & Superior. \\
\hline $\begin{array}{l}\text { Corolla. } \\
\text { petals. }\end{array}$ & 5 & Polypetalous. & Epigynous. \\
\hline Stamens. & 5 & Pentandrous. & Epigynous. \\
\hline $\begin{array}{l}\text { Pistil. } \\
\text { carpeis. }\end{array}$ & 5 & Syncarpous. & Inferior. \\
\hline Sceds. & \multicolumn{3}{|c|}{ I to 5 in each berry, albumen rumisate } \\
\hline
\end{tabular}


Compare the fruit of Ivy with that of an Umbellifer. The chief difference is in the increased number of carpels, which do not separate from each other when ripe, in the former. A species of Panax growing in the north of China and Mantchuria affords ginseng, highly esteemed as a restorative medicine by the Chinese. It is sold at from 20 to 250 times its weight in silver, though possessing no active medicinal properties.

Rice-paper is prepared from the pith of Aralia papyrifera, a tree of Formosa: the pith is cut spirally and unrolled into small squares of $2 \frac{1}{2}$ or 3 inches, which are sold by the Chinese for $1 \frac{1}{4} d$. or $1 \frac{1}{2} d$. per 100 .

31. Natural Order.-Loranthaceæ. The Mistletoe Family.

Distribution.-Tropics of both hemispheres, with comparatively few species in the temperate zones.-One British genus, species 1.

Type-Common Mistletoe (Viscum album).

A dichotomous parasitical shrub, with opposite leathery leaves, and inconspicuous diœcious flowers. (The only British species.)

\begin{tabular}{|c|c|c|c|}
\hline Organ. & No. & Cohesion. & Adhesion. \\
\hline $\begin{array}{l}\text { Perianth. } \\
\text { i.eaves. }\end{array}$ & 4 & Polyphyllous. & superior. \\
\hline o, Stamens. & 4 & Tetrandrous. & Epiphyllous. \\
\hline$\delta$, Pistil. & 0 & & \\
\hline o, Stamens. & 0 & & \\
\hline $\begin{array}{l}\text { 9, Pistil. } \\
\text { carpels. }\end{array}$ & 2 & Syncarpous. & Inferior. \\
\hline Seeds. & Solit & $\mathrm{cy}$, albuminous & radicle superior. \\
\hline
\end{tabular}


Mistletoe is the only representative of this Family of woody parasites in Britain, which in the tropics are numerous, including many species with large and brilliant flowers.

OBSERVE a cross section through the attachment of Mistletoe to its stock ; it shows the intimate union, without intermingling, of the tissues of larasite and prey: the viscous tissue of the ripe pericarp, which secures the adhesion of the seed to the bark of trees when conveyed by birds. In germinating the radicle penetrates the bark, forming a kind of rhizomatous root, which applies itself to the young alburnum of the stock, preying upon the ascending sap, which is further elaborated in the leaves of the Mistletoe. Obserre, also, the anthers, adherent to the lobes of the perianth, and dehiscing by pores.

The structure of the inferior ovary of the Order has been much misunderstood. If cut across, there is no cavity containing an ovule to be seen. This is owing to the circumstance that the sides of the ovary are adherent to the solitary, erect, naked ovule, so that no distinction between ovary and ovule is apparent. The albuminous seeds frequently contain 2 or more embryos, as is also usually the case with the exalbuminous seeds of the Orange.

Mistletoe grows upon trees belonging to very different Natural Orders ; in Britain, chiefly upon the Apple, Thorn, Maple, and Lime. It rarely occurs upon the Oak.

\section{Natural Order-Cornacen. The Comel Family.}


Distribution.-Widely dispersed in both hemispheres.-One British genus, species 2.

Shrubs or herbs. Corolla epigynous, regular. Ovary 2-celled.

Type-Common Cornel (Cornus sanguinea).

A deciduous shrub, with opposite entire leaves, and small white cymose fiowers.

\begin{tabular}{|c|c|c|c|}
\hline Organ. & No. & Cohesion. & Adhesion \\
\hline $\begin{array}{l}\text { Calyx. } \\
\text { sepals. }\end{array}$ & $4(5)$ & Gamosepalous. & Superior. \\
\hline $\begin{array}{l}\text { Corolla. } \\
\text { petals. }\end{array}$ & $4(5)$ & Polypetalous. & Epigynous. \\
\hline Stamens. & $4(5)$ & Tetrandrous. & Epigynous. \\
\hline $\begin{array}{l}\text { Pistil. } \\
\text { carpels. }\end{array}$ & 2 & Syncarpous. & Inferior. \\
\hline Seeds. & Solita & rry in each cell, & Ibuminous. \\
\hline
\end{tabular}

OBSERve the white involucral bracts of Dwarf Cornel (Cornus suecica) and of $C$. florida, the latter an American species. The involucres give the small flower-heads the appearance of single flowers.

\section{Division.' Gamopetalæ (Corolliflorce).}

33. Natural Order-Caprifoliaceæ. The Honeysuckle Family.

Distribution.-Chiefly in temperate and subtropical regions of both hemispheres.-British genera 5 , species 8 .

Shrubs or herbs. Corolla epigynous. Stamens epipetalous. Ovary $3-5$-celled. 
Type-Common Honeysuckle (Lonicera peri, clymenum.)

A woody climber, with opposite entire leaves, and terminal heads of fragrant irregular flowers.

\begin{tabular}{|c|c|c|c|}
\hline Organ. & No. & Cohesion. & Adhesion. \\
\hline $\begin{array}{l}\text { Calyx. } \\
\text { sepuls. }\end{array}$ & 5 & Gamosepalous. & Superior. \\
\hline $\begin{array}{l}\text { Corolla. } \\
\text { petals. }\end{array}$ & 5 & $\begin{array}{l}\text { Gamopetalous } \\
\text { (irregular). }\end{array}$ & Epigynous. \\
\hline Stamens. & 5 & Pentandrous. & Epipetalous \\
\hline $\begin{array}{l}\text { Pistil. } \\
\text { carpels. }\end{array}$ & 3 & Syncarpous. & Inferior. \\
\hline
\end{tabular}

OBSERve the thick cellular pith of Elder (Sambucus nigra), useful for pith-balls for electrical experiments, and the cylinder of wood, after the pith is removed, for popguns. Observe, also, the enlarged lobes of the corolla in cultivated varieties of Guelder Rose (Viburnum opulus). In the wild form, the outer flowers only of the cymes are enlarged in this way, at the expense of the essential organs: they are barren or neuter, in consequence.

Observe, also, Tuberous Moscatel (Adoxa moschatellina), a low, tender herb, with small capitate flowers, of which the upper one of each head has 4 , and the four lateral flowers each 5, stamens. The stamens are branched, and each branch bears one lobe of the anther, so that the flowers appear to be octandrous or decandrous. Compare the neuter flowers of Guelder Rose and Hydrangea: in the former the lobes of the corolla, in the latter the lobes of the calyx, are enlarged. 
Linncea borealis, a small creeping wiry evergreen, with pretty pendulous flowers, native of Scotland, and common in the North of Europe, is named after Linnæus, who is represented in his portraits with a sprig of this plant in his buttonhole.

34. Natural Order-Rubiacer. Tribe Stellatie. The Stellate Tribe of the Madder Family,

Distribution.-Dispersed through temperato regions of both hemispheres; less numerous between the tropics, where, howe ver, typical Rubiacer abound.-British genera 4, species 14 .

Herbs. Leaves verticillate. Corolla epigynous.

Stamens epipetalous. Ovary 2-celled.

Type-Woodruff Asperule (Asperula odorata). (Sweet Woodruff.)

A perennial herb, with slender creeping rhizome, erect stem with verticillate leaves, and a terminal cyme of small white flowers.

\begin{tabular}{|l|r|r|l|}
\hline \multicolumn{1}{|c|}{ Organ. } & No. & \multicolumn{1}{c|}{ Cohesion. } & \multicolumn{1}{c|}{ Alhesion. } \\
\hline $\begin{array}{l}\text { Calyx. } \\
\text { sepals. }\end{array}$ & 4 & Gamosepalous. & Superior. \\
\hline $\begin{array}{l}\text { Corolla. } \\
\text { petals. }\end{array}$ & -4 & Gamopctalous. & Epigynous. \\
\hline \begin{tabular}{l} 
Stancus. \\
\hline $\begin{array}{l}\text { Sistil. } \\
\text { corpels. }\end{array}$
\end{tabular} & \begin{tabular}{l} 
Tetrandrous. \\
\hline Seeds.
\end{tabular} & Syncarpous. & Inferior. \\
\hline
\end{tabular}

All British Rubiacer belong to the Tribe Stellatæ, characterised by the leaves in whorls. The more typical members of the Order abound in 
tropical countries, where many species are amongst the eommonest weeds. Others, however, are highly ornamental, and are cultivated in our planthouses. A few species are of great economic importance, especially the Coffee shrub (Coffea arabica), a native of Eastern Tropical Africa, but cultivated very extensively in Ceylon, the East and West Indian Islands, and Brazil. The seeds are contained, two together, in a fruit of about the size and colour of a Cherry. The pulp of the pericarp is removed by washing and mechanical contrivance, leaving the parchment-like endocarp immediately enclosing the seeds to be separated in a rolling mill.

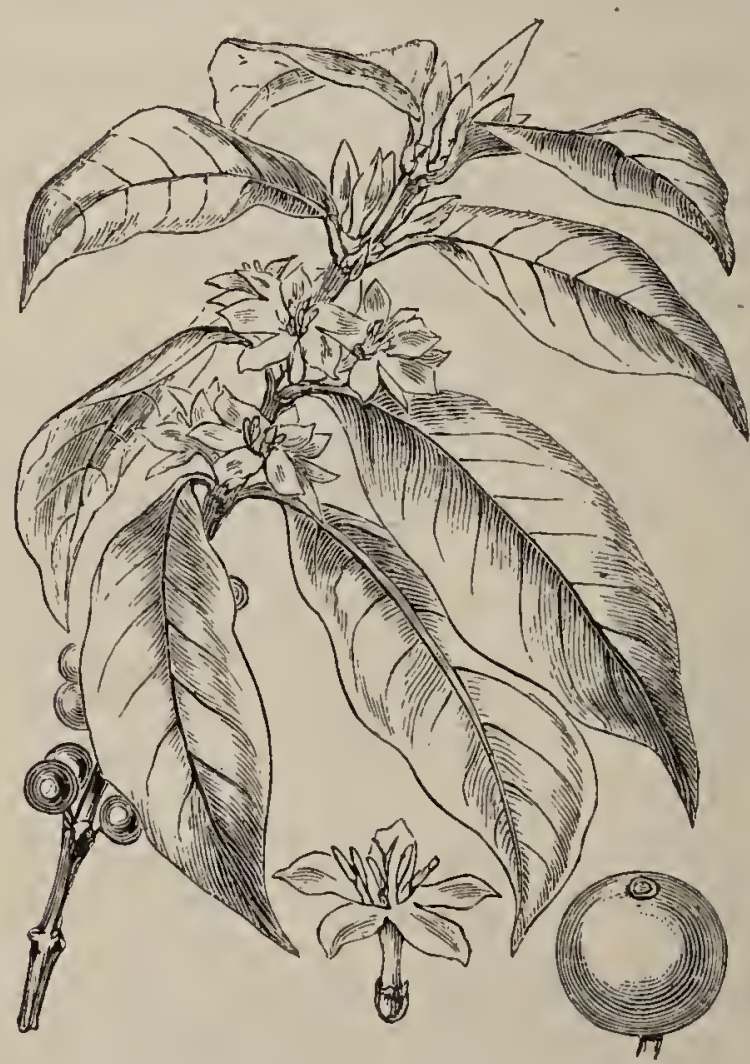

Fici. 112. Coffee shrub 'Coffa arubica). Reduced. A detached berry and fluwer below. 
In 1871 upwards of one hundred and ninety-two millions of pounds of Cuffee were imported, ninety one millions being from Ceylou alone. More than thirty millions of pounds were entered for home consumption.

Other important exotic species are the Quinineproducing Cinchonas or Peruvian barks, natives of the Andes of Peru, and now introduced into British India and Java: Ipecacuanha, the emetic root of Cephaëlis Ipecacuanha: and Rubiatinctorum, a plant of the Levant and Southern Europe, cultivated in France for the sake of its rhizome, which affords the valuable dye, Madder. Upwards of 283,000 cwts. of Madder and Garancine (the latter prepared from Madder by the action of sulphuric acid) were imported in 1872. Indian Madder is the produce of an allied species, $h$. cordifolia.

The seeds of Cleavers Galium, or Goose-grass (Galium Aparine), are said to have the flavour of Coffee when roasted.

35. Natural Order-Valerianeæ. The Valerian Family.

Distrmbutron.--Principally confined to the North Temperate Zone and South American Andes. -British genera 2, species 6 .

Herbs. Corolla epigynous. Stamens epipetalous, fewer than corolla lobes. Fruit 1-celled.

Type-CommonValerian(Valeriana officinalis). An erect perennial herb, with opposite pinnatified leaves, and terminal many-flowered cymes of small pale lilac or white fluwer's. 


\begin{tabular}{|c|c|c|c|}
\hline Organ. & No. & Cohesion. & Adhesion. \\
\hline $\begin{array}{l}\text { Calyx. } \\
\text { sepals. }\end{array}$ & 5 & Gamosepalous. & Superior. \\
\hline $\begin{array}{l}\text { Corolla. } \\
\text { petills. }\end{array}$ & 5 & Gamopetalous. & Epigynous. \\
\hline Stamens. & 3 & Triandrous. & Epipetalous. \\
\hline $\begin{array}{l}\text { Pistil. } \\
\text { carpels. }\end{array}$ & 3 & Syucarpous. & Inferior. \\
\hline Seeds. & \multicolumn{3}{|c|}{ Solitary, suspended, ex } \\
\hline
\end{tabular}

Observe the diœcious flowers of Marsh Valerian (Valeriara dioica) : the calyx of the ripe fruit of Common Valerian; at the time of flowering, the limb of the calyx is represented by a thickened rim, but as the fruit ripens the limb expands in the form of a crown of feathered hairs (pappus): the gibbous one-sided dilatation of the base of the corolla-tube in the same species; in Centranth (Centranthus) it is lengthened down into a spur: a transverse section of the ovary exhibits but a single cell containing one ovule, the other two cells being aborted.

Spikenard is the root of Nardostachys jatamansi, a North Indian plant. It has been highly valued as a perfume from early antiquity. The root of Common Valerian possesses a strong and peculiar odour, which acts powerfully on the nervous system of cats.

Corn-salad, or Lamb's-lettuce (Fedia olitoria), is eaten as a salad.

36. Natural Order-Dipsaceæ. The Teasel Family.

Distribution.- Temperate regions of the Old 
World, especially around the Mediterranean; also at the Cape of Good Hope.-British genera 2, species 5 .

Herbs. Stamens epipetalons, same number as corollolobes. Ovary 1-celled, inferior. Ovule pendulous.

Type-Blue Scabious (Scabiosa succisa).

Herb with a præmorse (abrupt) rootstock, onposite entire leaves, and terminal involucrate Hower-heads.

\begin{tabular}{|c|c|c|c|}
\hline Organ. & No. & Cohesion. & Adhesion. \\
\hline $\begin{array}{l}\text { Calyx. } \\
\text { sepals. }\end{array}$ & 4 & Gamosepalous. & Superior. \\
\hline $\begin{array}{l}\text { Corolla. } \\
\text { petals. }\end{array}$ & 4 & Gamopetalous. & Epigynous. \\
\hline Stamens. & 4 & Tetrandrous. & Epipetalous. \\
\hline $\begin{array}{l}\text { Pistil. } \\
\text { carpels. }\end{array}$ & 2 & Syncarpous. & Inferior. \\
\hline
\end{tabular}

Obsenve the small invalacel euclosing each individual flower, very easily mistaken for a calyx : the rigid pointed bracts of the flowers of Fuller's Teasel ( $D$. fullonum). The heads are fixed into frames, and used to give a "nap" to woollen cloth, by raising the fine fibres of the fabric to the surface, by means of the pungent bracts : the comnate leaves of Common Teasel, which collect the rain and dew that trickle down the stem.

The specics of Dipsacex are easily distinguished from Composites by their free anthers, and the pendulous ovule. 


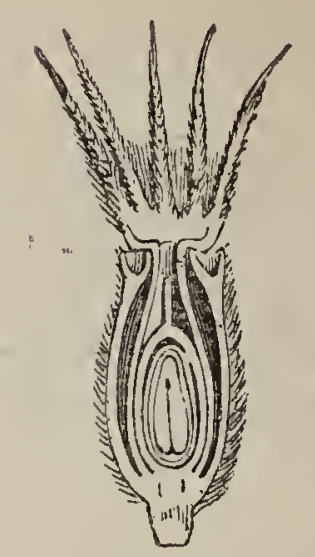

F1G. 113. Vertical section of a fruit of Field Scabious, showing the calyx-tube enclosed in an involucel. The limb of the calyx is multipartite.

37. Natural Order-Compositæ. The Composite Family.

Distribution.-Numerous in every quarter of the globe, especially in the Tropics, where a large proportion is shrubby or arborescent. - British genera 40 , species 113 .

Herbs. Flowers (florets) capitate. Stamens 5, syngenesious. Ovary 1-celled, inferior; ovule erect.

Types-Spear Thistle (Carduus lanceolatus), or Dandelion (T'araxacum Dens-leonis).

The former an erect herb, with alternate pinnatifid prickly leaves, and terminal prickly globose flower-heads of purple florets; the latter with radical runcinate leaves, and a hollow radical peduncle (scapo), bearing a solitary head of bright yellow florets. 


\begin{tabular}{|l||r|l|l|}
\hline \multicolumn{1}{|c|}{ Organ. } & No. & \multicolumn{1}{c|}{ Cohesion. } & \multicolumn{1}{|c|}{ Adhesion. } \\
\hline $\begin{array}{l}\text { Calyx. } \\
\text { sepals. }\end{array}$ & 5 & Gamosepalous. & Superior. \\
\hline $\begin{array}{l}\text { Corolla. } \\
\text { petals. }\end{array}$ & 5 & Gamopetalous. & Epigynous. \\
\hline \begin{tabular}{l} 
Stamens. \\
\hline $\begin{array}{l}\text { Pistil. } \\
\text { carpels. }\end{array}$
\end{tabular} & \begin{tabular}{ll}
\hline \\
Syngenesious.
\end{tabular} & Syncarpous. & Epipetalous. \\
\hline Seeds. & \multicolumn{2}{|c|}{ Solitary, erect, exalbuminous. } \\
\hline
\end{tabular}

N.B.-The carpels are described as two in number. This is inferred from the 2-lobed stigma.

The ovary is invariably 1-celled, with a solitary erect ovule. The number of sepals is inferred from analogy.

Compare, in respect of the form of the corolla of the florets, Spear Thistle, Daisy, and Dandelion.

In Spear 'Thistle they are all tubular.

In Daisy, the outside florets are irregular, one-sided, strap-shaped (ligulate), and white.

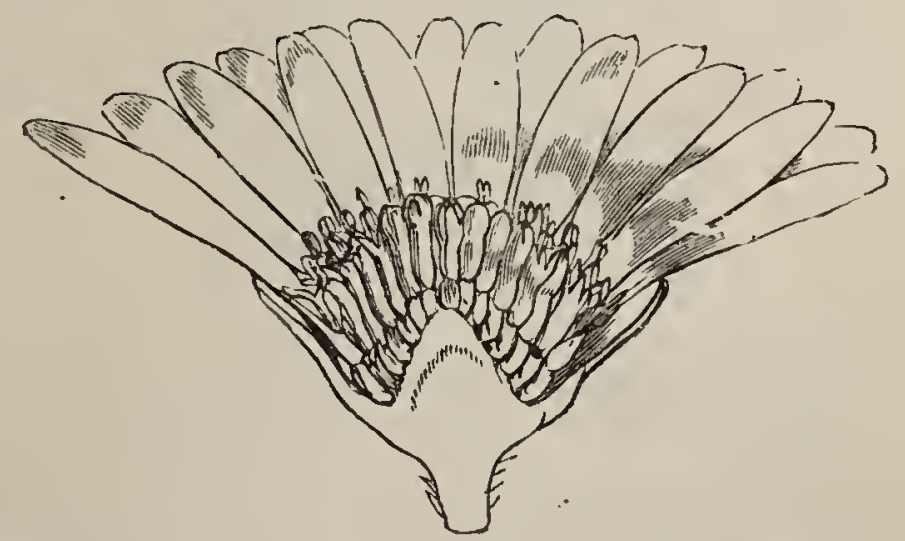

1710. 114. Verticis section of llower lital us nasy : 
constituting the ray; the inner florets are much smaller, regular, tubular, and yellow, constituting the disk. In Daisy, and many other plants with ray and disk florets as in that species, the florets of the disk are apt all to become ligulate under cultivation.

In Dandelion, all the florets are like the florets of the ray of the Daisy in form; they are all ligulate and yellow.

Our British Composites may be grouped under two Tribes: Tubuliflora, with all the florets (Spear Thistle), or those of the disk only (Daisy), tubular; and Liguliflorce, with all the florets ligulate (Dandelion).

The florets of Ligulifloræ are all perfect, i.e. they each contain both stamens and pistil.

The florets of Tubulifloræ may be either all perfect (Spear Thistle); or the outermost florets may be neuter (Corn Centaurea, or Bluebottle),

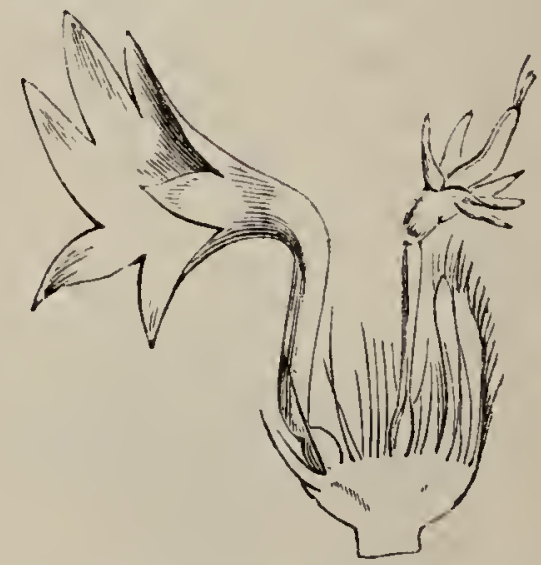

51a. 115. Vertical section of flower-head of Corn Centaurea, one neuter ray-floret and owe disk-floret being left.

or pistillate (Daisy, or Chamomile) ; or the florets may be monocious, those of the disk being staminate, those of the ray pistillate (Common 
Marigold, Calendula); or the flower-heads may be diœcious (Mountain Cudweed, Gnaphalium dioicum).

If all the florets of a flower-head (capitulum) be perfect, the flower-heads are homogamous

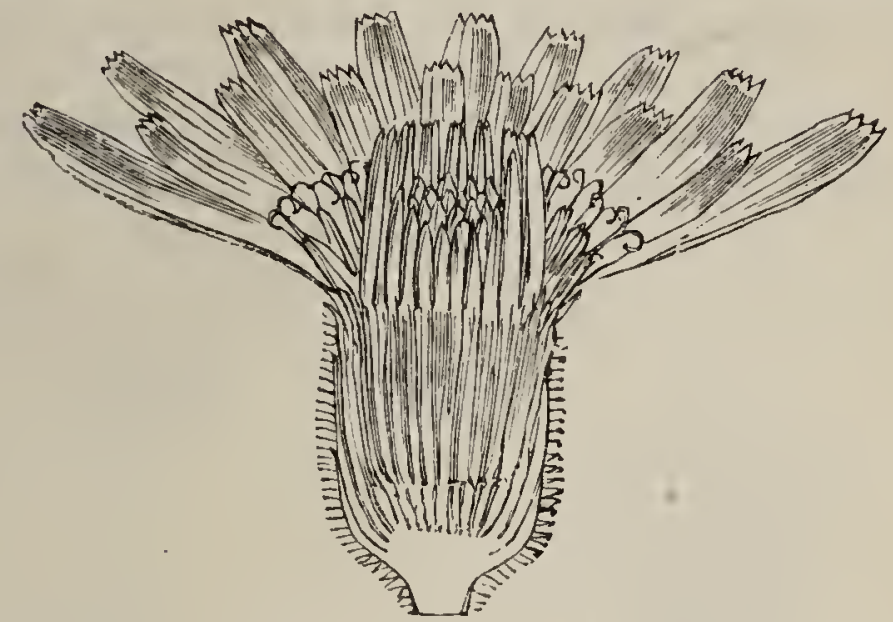

Fra. 116. Vertical section through flower-head of Sowthistle.

(Dandelion, Sowthistle); if part of them be imperfect, the heads are heterogamous (Daisy).

COMPARE the common receptacles of Dandelion and Common Chamomile (Anthemis robilis) after re-

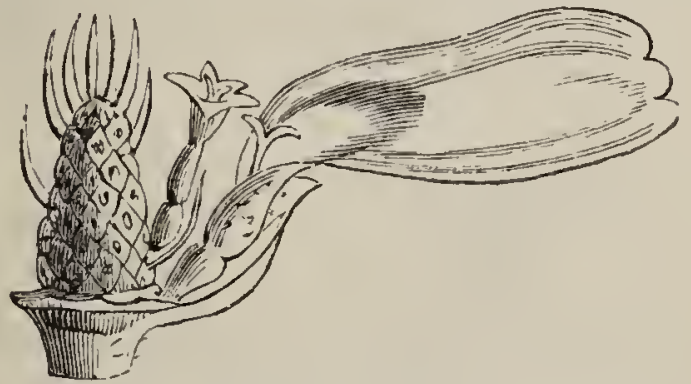

Fir. 117. Chaffy (paleaceous) common receptacle of the Chamomile.

moving the florets. In the former it is naked, in the latter covered with small chaffy scales (paleaceous). In some plants the bracts of the involucre pass gradually into the palew of the common receptacle. 
Compare, also, the fruit-achenes of Thistle, Dandelion, and Daisy.

In Thistle they are crowned by a sessile crown of hairs, called a pappus (representing the limb of the calyx in Composites); in Dandelion by a stalked (stipitate) pappus. In Daisy the pappus is obsolete.

The Composite Family is the largest and at the same time one of the best defined in the Vegetable Kingdom. The eight or nine thousand
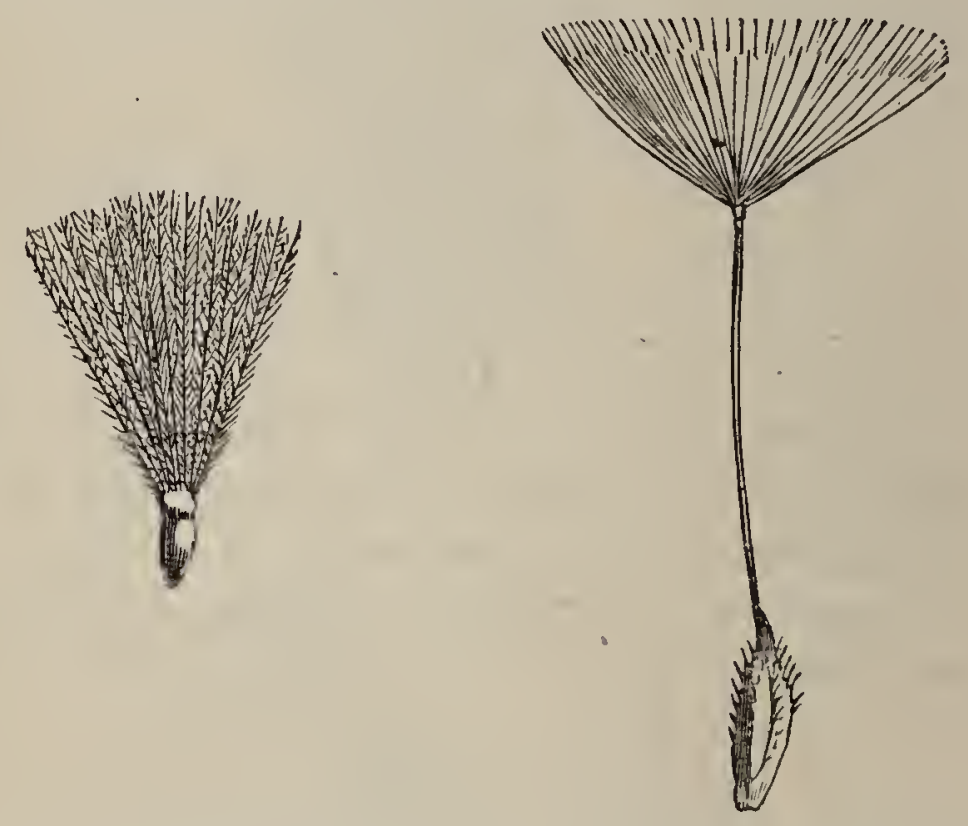

FIa. 118. Fruit of Thistle, with Frg. 119. Fruit of Dandelion sessile, plumose pappus.

with stipitate pappus.

species which compose the Order nearly all agree in their capitate inflorescence, the 5 stamens with syngenesious anthers, the 1-celled ovary containing a single erect ovule, and the dry achene, in common language incorrectly called a "seed."

Note amongst Tubulifloræ :-

Coltsfoot (Tussilags), with the flowers appearing in early spring, before the leaves. 
Sunflower (Helianthus annuus), the seeds of which yield a valuable oil ; and Jerusalem Articholke (H.tuberosus). The latter species rarely flowers in cultivation, except in hot summers. It is of tropical American origin.

Monstrous condition of Daisy (Bellis perennis), in which small flower-heads are borne in the axils of the bracts of the involucre, as in "Hen-and-Chickens Daisy."

Garden Chrysanthemums (Chrysanthemum indicum), the florets all ligulate under culture. Many beautiful varieties, differing in colour and form (whether flat or "quilled") of the ligulate florets, are grown.

Chamomiles (Anthemis nobilis), the dried flowerheads used medicinally in infusion as "chamomile-tea."

'Thistle, Onopord, and others, with decurrent, often prickly leaves : Creeping Thistle (Carduus arvensis) is a too common weed in pastures, propagating itself by a creeping rhizome, every node of which is capable of giving off a shoot; the flower-heads are diceious.

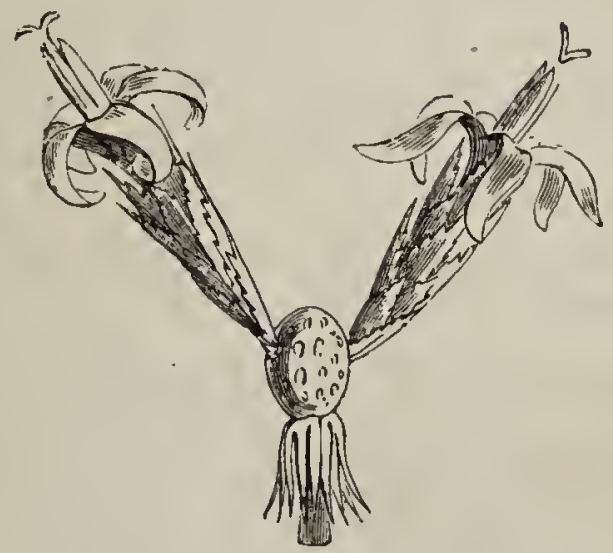

Fis. 120. Flower-head of Echinops, but two florets remain. 
Echinops, with globular flower-heads and each floret enclosed in a special involucel.

Artichoke (Cynara Scolymus), introduced into the pampas of South America, has spread over a large tract of country in such abundance as to form impenetrable masses when in flower. C. Cardunculus is the Cardoon.

Safflower, the dried corollas of Carthamus tinctorius, made up into cakes. It affords an excellent rose dye, and, treated with carbonate of soda and lemon-juice, rouge.

Everlastings, the flower-heads of species of $\mathrm{Heli}$ chrysum, Gnaphalium, \&c. called "Everlastings" from their dry, scarious, persistent involucres. They are fastened together into wreaths and chaplets, and sold in France, as "immortelles" to deck the tombs of friends.

Amongst Ligulifloræ (characterised, besides the perfect, ligulate florets, by milky juice) note-

Salsify and Scorzonera, the esculent roots of Tragopogon porrifolium and Scorzonera hispanica.

Dondelion, the roots used in rustic medicine.

Chicory, the kiln-dried, and then roasted and powdered root of Cichorium Intybus, used extensively to mix with coffee. To detect its presence in ground coffee, add a little of the suspected mixture to a glass of water. If Chicory be present, a yellowish tinge will be rapidly imparted to the water.

Catanariche corulea of the South of Europe is one of the few ornamental species afforded by Ligulifloræ. The Tribe Tubulifloræ, on the other hand, is rich in garden flowers, including, besides Chrysanthemums and Sunflowers, Dahlia, French. 
and African Marigolds (Peruvian species of T'agetes), Zinnia, Cineraria, Senecio, \&c.

38. Natural Order-Campanulaceæ. The Carnpanula Family. (Bell-flowers.)

Distribution.-Temperate regions of buth hemispheres; a large proportion affecting mountainous situations.-British genera 4 . species 14.

Herbs. Stamens 5, epigynous. Ovary 2-5-celled, ovules indefinite.

Type-Harebcll Campanula (Campanula rotundifolia).

A decumbent perennial herb, with milky juice, rounded or cordate radical, and alternate linear cauline leaves, and racemose few-flowered cymes of drooping blue flowers.

\begin{tabular}{|c|c|c|c|}
\hline Organ. & No. & Cohesion. & Adhesion. \\
\hline $\begin{array}{l}\text { Calyx. } \\
\text { sepals. }\end{array}$ & 5 & Gainosepalous. & Superiur. \\
\hline $\begin{array}{l}\text { Corolla. } \\
\text { petals. }\end{array}$ & 5 & Gamopetalous. & Epigynous. \\
\hline Stamens. & 5 & Pentandrous. & Epigynous. \\
\hline $\begin{array}{l}\text { Pistil. } \\
\text { carpels. }\end{array}$ & 3 & Syncarpous. & Inferior. \\
\hline Seeds. & \multicolumn{3}{|c|}{ Indefinite, placeutation axile. } \\
\hline
\end{tabular}

A deviation from this type we find in Lobelia and some allied exotic genera, in which the corolla is irregular, and the anthers usually more or less distinctly syngenesious.

OBSERve the valvate æstivation of the corolla: the early dehiscence of the anthers : the node of dehiscence of the capsule. 
In some species two kinds of tiower are produced-one of the usual form, the other very minute and with the corolla hermetically sealed over the stamens and pistil, so as to insure selffertilization. The root of Campanula Rapunculus is cooked, under the name of Rampion. This is the only esculent species. Several are favourite garden flowers.

39. Natural Order - Ericaceæ. The Heath Family.

Distribution.-Arctic and temperate zones of both hemispheres, excepting in Australia ; continued along the mountain ranges of the Tropics. One genus (Erica) very numerous at the Cape of Good Hope.-British genera 7, species 23.

Wiry shrubs. Stamens 8 or 10 , epigynous or hypogynous.

Type-Scotch Heath (Erica cinerea).

A low bushy wiry shrub, with narrow-linear leaves, and racemose clusters of purple flowers.

\begin{tabular}{|c|c|c|c|}
\hline Organ. & No. & Cohesion. & Adhesion. \\
\hline $\begin{array}{l}\text { Calyx. } \\
\text { sepals. }\end{array}$ & 4 & Polysepalous. & Inferior. \\
\hline $\begin{array}{l}\text { Corolla. } \\
\text { petals. }\end{array}$ & 4 & Gamopetalous. & Hypogynous. \\
\hline S'tamens. & 8 & Octandrous. & Hypogynous. \\
\hline $\begin{array}{l}\text { Pistil. } \\
\text { carpels. }\end{array}$ & 4 & Syncarpous. & Superior. \\
\hline Seeds & Seve & ral in each cell. & \\
\hline
\end{tabular}

The Bilberry Vaccinium or Whortleberry ( $V a c$ cinium Myrtillus) may be taken as the repre- 
sentative Sub-type of those species which have the ovary adherent to the calyx-tube, the corolla and stamens being consequently epigynous.

Observe the persistent (marcescent) corolla of Heaths : the anthers dehiscing by pores at the top, and often with spur-like appendages at the base.

Compare the fruits of Heath and Bilberry, in the former a capsule, in the latter a berry.

Very few species of the Heath Type are of economic importance, though many are exceedingly beautiful and universal favourites in cultivation; amongst the rest are the Rhododendrons, Azaleas, Kalmias, and the elegant species of Heath introduced from the Cape of Good Hope.

Some species of the Vaccinium Sub-type afford a useful fruit, as Bilberry and Cranberry (V. Oxycoccus).

40. Natural Order-Primulaceæ. The Prim. rose Family.

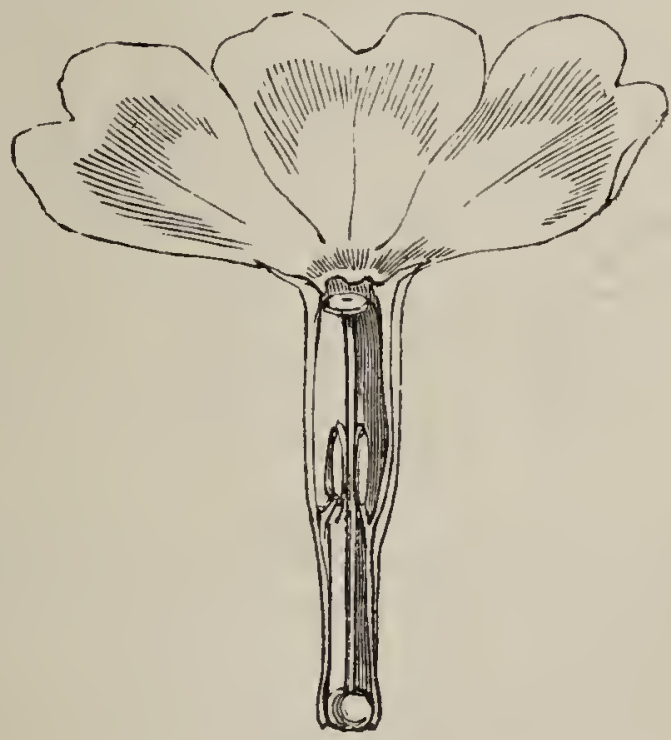

Fia. 121. Vertical section of flower of Primrose. 
Distribution.- Most numerous in the Nurth temperate zone, especially affecting mountainranges.-British genera 9 , species 15 .

Herbs. Corolla hypogynous. Stamens 5, epipetalous, opposite to the corolla lobes. Placenta free, central.

Type-Common Primrose (Primula vulgaris).

A perennial herb, with oblanceolate wrinkled radical leaves, and pale yellow flowers borne on slender 1-flowered scapes.

\begin{tabular}{|l||r|l|l|}
\hline \multicolumn{1}{|c|}{ Organ. } & No. & \multicolumn{1}{c|}{ Cohesion. } & \multicolumn{1}{c|}{ Adhesion. } \\
\hline $\begin{array}{l}\text { Calyx. } \\
\text { sepals. }\end{array}$ & 5 & Gamosepalous. & Inferior. \\
\hline $\begin{array}{l}\text { Corolla. } \\
\text { petals. }\end{array}$ & 5 & Gamopetalous. & Mypogynous. \\
\hline \begin{tabular}{l} 
Stamens. \\
\hline $\begin{array}{l}\text { Pistil. } \\
\text { carpels. }\end{array}$
\end{tabular} & -5 & $\begin{array}{l}\text { Pentandrous. } \\
\text { Syncarpous. }\end{array}$ & \begin{tabular}{l} 
Epipetalous. \\
\hline Superior.
\end{tabular} \\
\hline
\end{tabular}

OBSERve the stamens opposite to the lobes of the corolla: the 1-celled ovary with a central placenta wholly free from the sides of the ovary from its first origin: the ovary half inferior in Samolus : the fruit dehiscing transversely in Pimpernel (Anagallis): the absence of a corolla in Glaux. In this genus the calyx is coloured like a corolla.

Compare the inflorescence of Primrose, Cow$\operatorname{slip}(P$. veris $)$, and Chinese Primrose ( $P$. sinensis), the latter a common parlour plant. It is essentially similar in all, but in Primrose the peduncle is arrested close to the stock, so that the pedicles 
only appear. Sometimes it lengthens out, bearing an umbel of flowers, as in Cowslip. In Chinese

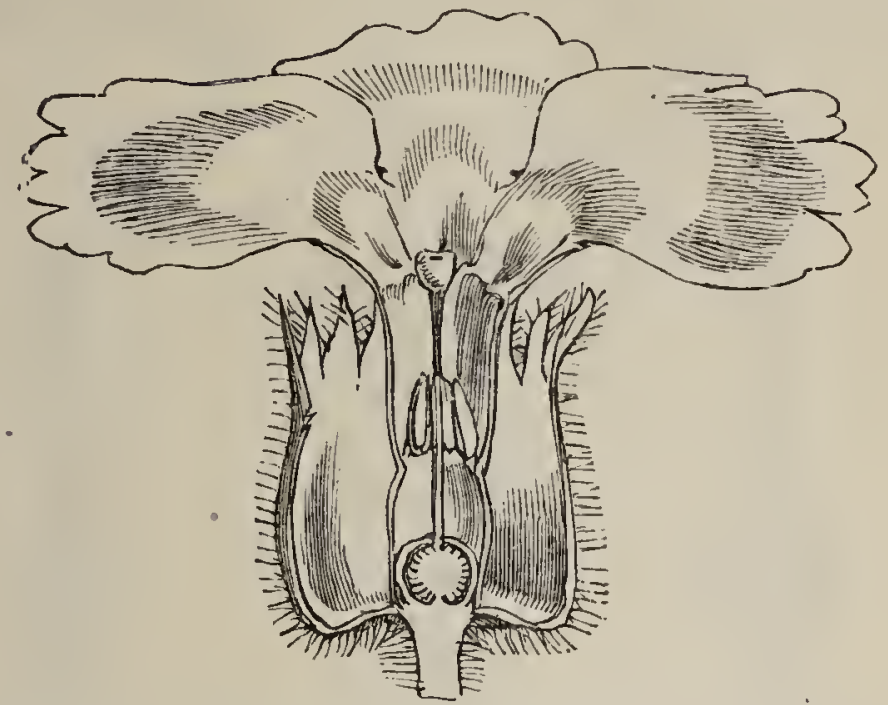

Fro. 122. Vertical section of flower of Primula sinensis.

Primrose the peduncle does not terminate in a single umbel, but is prolonged beyond it, bearing a second or third umbel; all the flowers, excepting those of the terminal umbel, becoming, in consequence, whorled.

In Cyclamen the embryo has but 1 cotyledon; in some species of Cyclamen this cotyledon enlarges, persists, and becomes a "foliage-leaf." The "tigellum" of the embryo enlarges, forming a thick perennial corm, from which leaves and flowers annually rise. It is called Sowbread in Sicily, where the will boars root it up for food. The fishermen use it to expel cuttle-fish from their hiding-places among the rocks, in order to procure their ink-bags, which are dried to furnish sepia used in water-colour drawing. 
41. Natural Order-Oleacex. The Olive Fanily.

Distributron.-Widely dispersed through both hemispheres, rare in tropical America.-British genera 2, species 2.

Tree or shrub. Leaves opposite. Stamens 2.
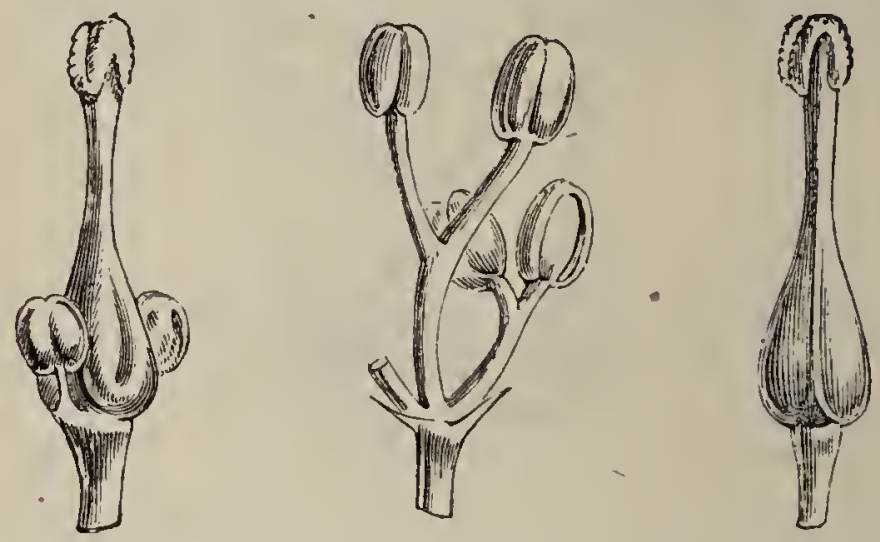

FIG. 123. Flowers of Ash; $a$, the hermaphrodite flower; $b$, two staminate (diandrous) flowers; $c$, pistillate flower.

Type-Common Ash (Fraxinus excelsior).

A tall deciduous tree, with opposite pinnate leaves, and inconspicuous polygamous flowers.

\begin{tabular}{|c|c|c|c|}
\hline Organ. & No. & Cohesinn. & Adhesion. \\
\hline $\begin{array}{l}\text { Calyx. } \\
\text { sepals. }\end{array}$ & 0 & Asepalous. & \\
\hline $\begin{array}{l}\text { Corolla. } \\
\text { petals. }\end{array}$ & 0 & Apetalous. & \\
\hline Stamens. & 2 & Diandrons. & Hypogynous. \\
\hline $\begin{array}{l}\text { Pistil. } \\
\text { carpels. }\end{array}$ & 2 & Syncarpous. & Superior. \\
\hline
\end{tabular}


Although the Ash is the most accessible specier it cannot be accepted as representing the prevaler..

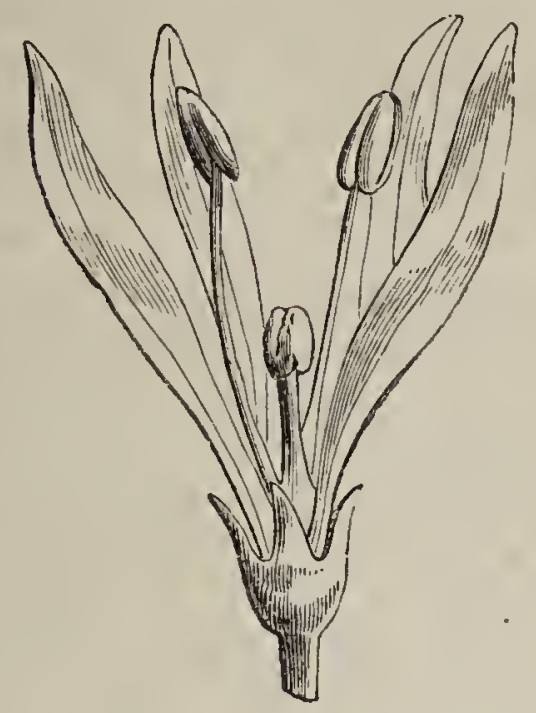

F10. 124. Flower (dichlamydeous) of Flowering Ash. structure of the Order, since the flowers of Oleacese are usually hermaphrodite, and provided with both

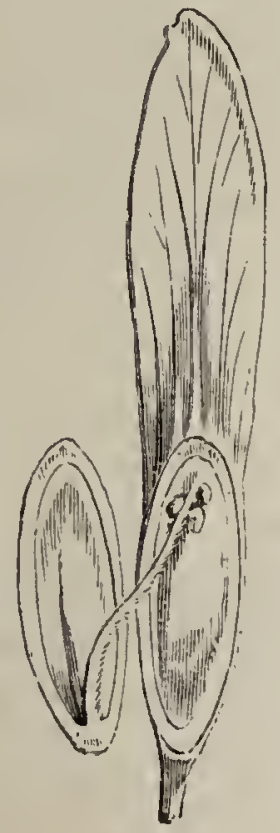

Fia. 125. Winged fruit (samara) of $\Delta \mathrm{sh}$, laid open.

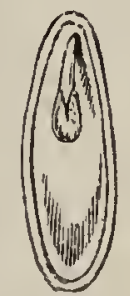

Ftr. 120. Inngitudinal section of albuninous seed of same. 
calyx and corolla, as in Privet (Ligustrum), the only native species of the Order in Britain besides the Ash. The case of the Ash serves, however, to show that the suppression of calyx and corolla in a single species or genus of a Natural Order is not regarded as of sufficient moment to warrant its removal to the Incompletx. In another (South European) species of Ash ( $F$. Ornus), called the Flowering Ash, calyx and corolla are present.

The flowers of Common Ash are termed polygamous, because they are either staminate, pistillate, or hermaphrodite, and the different kinds of flowers may be upon the same or different trees. In a variety of the Ash, called the "Weeping Ash," the branches are naturally pendulous. The original of this variety, from which all have been propagated by cuttings, is said to hcve been found in Cambridgeshire. Young plants, raised from seeds of the Weeping Ash by Professor Henslow, had a tendency to "weep" in their first branching, but the anomaly disapneared in two or three years in several young trees which he raised.

The wood of the Ash is very tough and elastic, and valued by cart- and wheelwrights. Manna is the concrete sap of species of Ash ( $F$. Ornus and $F$. rotundifolia), collected from wounds in the bark in summer and autumn. It is procured chiefly in Sicily and the South of Italy.

The Olive (Olea europoea), emblem of peace and plenty, a native of Syria and Greece, has been cultivated from a remote period on the shores of the Mediterranean, in Spain and the South of France, for the sake of the valuable oil (Olive-oil) expressed from the pulp of its drupaceous fruit.

The Lilac (Syringa) and Jessamine (Jasmi- 
num) are members of the Order, everywhere grown in gardens. Observe the symmetry of the flowers of these two plants, representing two divisions of the Order, the former with the parts of the calyx and corolla in fours and valvate in bud, the latter with five or more divisions to the corolla and overlapping (imbricate) in æstivation:

42. Natural Order-Apocynaceæ. The Periwinkle Family.

Distribution.-Chiefly tropical, with but comparatively few outliers in temperate regions.-One British genus (scarcely indigenous), species 2. Type-Lesser Periwinkle (Vinca minor).

A trailing wiry evergreen, with opposite entire shining leaves, and large blue solitary axillary Howers.

\begin{tabular}{|c|c|c|c|}
\hline Organ. & No. & Cohesion. & Aclhesion. \\
\hline $\begin{array}{l}\text { Calyx. } \\
\text { sepals. }\end{array}$ & 5 & Gamoselnalous. & Inferior. \\
\hline $\begin{array}{l}\text { Corolla. } \\
\text { petals. }\end{array}$ & 5 & Gamopetalous. & Hyровуnоus. \\
\hline Stamens. & 5 & Pentandrous. & Epipetalous. \\
\hline $\begin{array}{l}\text { Pistil. } \\
\text { carpels. }\end{array}$ & 2 & Syncarpous. & Supertor. \\
\hline Seeds. & \multicolumn{3}{|c|}{ Several in each follicle. } \\
\hline
\end{tabular}

OBserve the contorted xstivation of the unequal-sided lobes of the corolla: the hour-glass contraction of the stigma: the carpels, free at the base (ovary), consolidated in the style and stigma; ultimately (in fruit) wholly free.

Generally, the Apocynaceæ are dangerous. Sevea out of twelve French soldiers, at Madrid, 
are said to have died from using a spit of the wood of the Oleander (Nerium) in cooking; and a kernel of the Madagascar Ordeal-poison (T'anghinia) is stated to be sufficient to kill twenty people. This

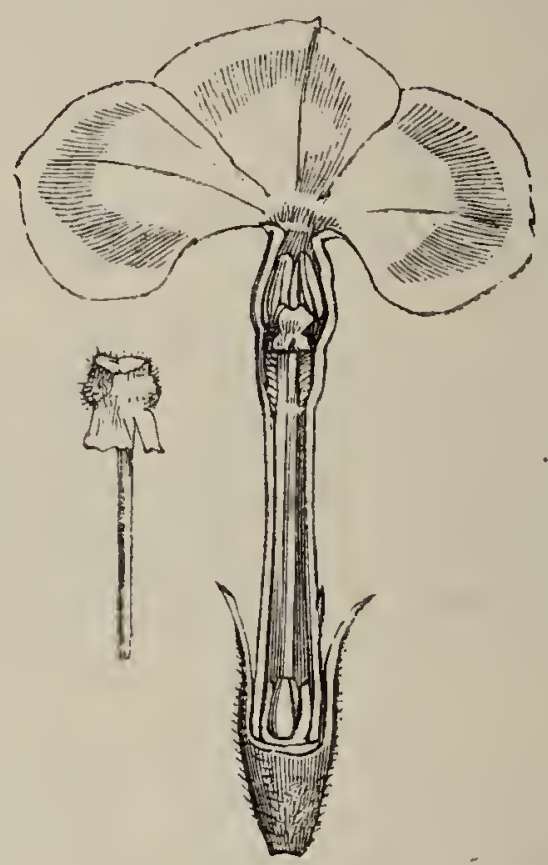

F1G. 127. Vertical section of flower of Vinca roseu. The transversely constricted annulate stigma to the left.

ordeal used to be employed in cases of suspected witcheraft or apostasy. Some tropical species of the Family abound in a milky juice, which is collected for the sake of its caoutchouc.

Closely allied to Apocynaceæ is the exotic Asclepias Family, including the beautiful Hoyas and Stephanotus of our stoves and the Carrion-flowers (Stapelias) of South Africa. The pollen of Asciepiads is held together by a secretion of the anther-cell, so as to form pollinia resembling those of Orchids.

43. Natural Order-Gentianacex, The Gentian Fanily. 
Distribution.-Widely spread in both hemispheres; most numerous in temperate and alpine regions.-British genera 6, species 11 .

Herbs. Corolla hypogynous, regular, lobes twisted in bud. Stamens alternate with corollat-lobes. Ovary usually 1-celled, with parietal placentas.

Type-Autumn Gentian (Gentiana Amarella). A small erect smooth annual, with opposite entire leaves, and numerous purplish flowers.

\begin{tabular}{|c|c|c|c|}
\hline Organ. & No. & Cohesion. & Adhesion. \\
\hline $\begin{array}{l}\text { Calyx. } \\
\text { sepals. }\end{array}$ & 5 & Gamosepalous. & Inferior. \\
\hline $\begin{array}{l}\text { Corolla. } \\
\text { petals. }\end{array}$ & 5 & Gamopetalous. & Hypogynous. \\
\hline Stamens. & 5 & Pentandrous. & Epipetalous. \\
\hline $\begin{array}{l}\text { Pistil. } \\
\text { carpels. }\end{array}$ & 2 & Syncarpous. & Superior. \\
\hline
\end{tabular}

Observe the connate leaves of Perfoliate Chlora (Chlora perfoliata): trifoliate leaves and bearded petals of Buckbean (Menyanthes trifoliata) : orbicular floating leaves of Common Limnanth ( $\mathrm{Lim}$ nanthemum nymphoeoides).

The Order abounds in a bitter principle, and several species are used in medicine.

44. Natural Order-Convolvulaceæ. The Convolvulus Family.

Distribution. - Chiéfly tropical and subtropical, both in the Old and New World. British genera 3 , species 6 .

Twining or creeping herbs. Calyx polysepaluus. Corolls regular, hypogynous, lobes plaited in bud. 
Type-Lesser Convolvulus (Convolvulus ar vensis).

(Bindweed.)

A twining oi prostrate herb, with alternate sagit. tate leaves, and axillary pedunculate flowers with handsome plaited corollas.

\begin{tabular}{|l||r|l|l|}
\hline \multicolumn{1}{c|}{ Organ. } & No. & \multicolumn{1}{c|}{ Cohcsion. } & \multicolumn{1}{c|}{ Adhesion. } \\
\hline $\begin{array}{l}\text { Calyx. } \\
\text { sepals. }\end{array}$ & 5 & Polysepalous. & Inferior. \\
\hline $\begin{array}{l}\text { Corolla. } \\
\text { petals. }\end{array}$ & -5 & Gamopetalous. & Hypogynous. \\
\hline \begin{tabular}{ll} 
Stamens. \\
\hline $\begin{array}{l}\text { Pistil. } \\
\text { car'pels. }\end{array}$
\end{tabular} & -5 & Pentandrous. & Epipetalous. \\
\hline Seeds. Two in each cell, cotyledons plaited. \\
\hline
\end{tabular}

OBSERve the folded restivation of the corolla: the anomalous genus Dodder (Cuscuta), the species of which are leafless twining parasites germinating in the soil, but becoming attached to their prey (Furze, Clover, Flax, \&c.) at an early stage of growth, by suckers, which penetrate the epidermis. The embryo of Dodder is filiform, coiled up in the albumen, and destitute of cotyledons. In some species ruaimentary cotyledons are formed at one extremity of the embryo.

Sweet Potatoes, cultivated all over the Tropics, are the fleshy rhizomes of Batatas edulis, probably a native originally of South America.

Jalap and Scammony are well-known drugs, furnished by the Order. The former (Exogonium) is brought from Mexico; the latter (Convolvulus Scammonia) from Asia Minor and Syria, where it is obtained by making oblique sections through 
the root, and allowing the milky juice to flow. This solidifies, and is the genuine Scammony of commerce.

The blue Convolvulus minor of gardens (colrectly $C$. tricolor) is a native of the South of Europe. The Major Convolvulus (Pharbitis purpurea), common in the Tropics, is probably an American species.

45. Natural Order-Boragineæ. 'The Borage Family.

Distribution.-Most numerous in South Europe and Western Asia, occurring also between the Tropics and southward in both hemispheres. -British genera 11, species 21.

Herbs. Calyx gamosepalous. Stamens same number as corolla-lobes. Ovary 4-lobed.

Type-Water Myosote (Myosotis palustris). (Forget-me-not.)

A perennial herb, with alternate entire leaves, and scorpioid cymes of rotate bright-blue flowers.

\begin{tabular}{|c|c|c|c|}
\hline Organ. & No. & Cohesion. & Adhesion. \\
\hline $\begin{array}{l}\text { Calyx. } \\
\text { sepals. }\end{array}$ & 5 & Gamosepalous. & Inferior. \\
\hline $\begin{array}{l}\text { Corolla. } \\
\text { petals. }\end{array}$ & 5 & Gamopetalous. & Hypogynous. \\
\hline Stamens. & 5 & Pentandrous. & Epipetalous. \\
\hline $\begin{array}{l}\text { Pistil. } \\
\text { carpels. }\end{array}$ & 2 & Syncarpous. & Superior. \\
\hline
\end{tabular}

OBSERve the inflorescence, resembling the indefinite raceme, but, in reality, a one-sided cyme, made up of as many superimposed axes as there 
are flower-bearing pedicles: the t-lobed ovary, resulting from 2 carpels each divided by an inflected dorsal suture, so that the lobes, each 1 -seeded, become separately detached when ripe : the style springing from the centre and base of the lobes of the ovary, termed gynobasic.

The herbage of Boraginea is often very coarse and hispid. A few species are common in flower-beds, as the Heliotrope.

The brownish-red dye Alkanet-root is obtained from Anchusa tinctoria, cultivated in the South of Europe.

46. Natural Order-Solanaceæ. The Solanum Family.

Distribution. - Most numerous in tropical and sub-tropical regions of both hemispheres. British genera 3 , species 4 .

Herbs or shrubs. Stamens same number as corolla-lobes. Ovary 2-celled, ovules indefinite.

Type-Bittersweet Solanum (Solanum Dulcamara).

A straggling deciduous shrub, with alternate petiolate often auricled leaves, and loose extraaxillary cymes of purple flowers.

\begin{tabular}{|c|c|c|c|}
\hline Organ. & No. & Cohesion. & Adhesion. \\
\hline $\begin{array}{l}\text { Calyx. } \\
\text { sepals. }\end{array}$ & 5 & Gamosepalous. & Inferior. \\
\hline $\begin{array}{l}\text { Corolla. } \\
\text { petals. }\end{array}$ & 5 & Gamopetalous. & Hypogynous. \\
\hline Stamens. & 5 & Pentandrous. & Epipetalous. \\
\hline $\begin{array}{l}\text { Pistil. } \\
\text { carpels. }\end{array}$ & 2 & Syncarpous. & Superior. \\
\hline Seods. & \multicolumn{3}{|c|}{ Several, albmminous, in red berries. } \\
\hline
\end{tabular}


Observe the frequently geminate leaves and extra-axillary inflorescence of the Order: the persistent accrescent calyx of Winter Cherry (Physalis Alkekengi), grown in cottage gardens: the anthers of Solanum opening by pores at the apex.: the albuminous seeds with, usually, a curved embryo: the fruit of Thorn-apple ( $D a$ tura), 4-celled, owing to the infolded dorsal sutures of the carpels, which reach and adhere to the placentas.

Although some species under cultivation are amongst our most valuable food-producing plants, the Order is dangerous, including the Deadly Nightshade (Atropa Belladonna), the berry of which, about the size and colour of a black clerry, has often proved fatal to children; Henbane (Hyoscyamus niger), a viscid weed of waste places about villages, with dingy, purple-veined, yellow flowers; and Tobacco (Nicotiana), the oil distilled from which is a virulent poison.

The narcotic principle of Tobacco is developed in the leaf by a fermentative process, after it has been collected. In 1868, upwards of forty millions of pounds of Tobacco were entered for home consumption. It is extensively grown in hot countries, especially in the Southern States of America, Cuba, South America, and the East Indian Islands.

The Potato-plant (Solanum tuberosum) is by far the most important member of the Order, affording our most valuable esculent. It was originally introduced from the South-western Coast of South America. Potatoes are the tubers or swollen portions of underground branches, and 
not roots, as the "eyes" (leaf-buds) of the tubers show. They contain about fifteen per cent. of starch, which may be roughly separated from the tissue of the Potato by grating and washing. From this starch are prepared dextrine, used in calico printing, and British gum, used to attach postage labels. The Potato disease is caused by a minute fungus (Botrytis infestans), which usually attacks the leaf in the first place, rapidly descending to the tubers. The starch of diseased tubers, while it remains, is perfectly wholesome.

Cayenne pepper is the ground seeds of species of Capsicum.

The fruits of the Aubergine (Solanum $M e$ longena) and Tomato (Lycopersicum esculentum) are used in cookery. The berry of Winter Cherry may be safely. eaten : it is cooked in Spain and Germany.

47. Natural Order - Scrophulariaceæ. The Scrophularia Family.

Distribution.-Widely diffused through both hemispheres, from the Arctic zone to the Equator. -British genera 13, species 50 .

Herbs. Corolla irregular. Stamens ferver than corollalobes (except Verbascum). Ovary 2-celled.

Type-Common Linaria (Linaria vulgaris). (Toadflax.)

An erect perennial herb, with numerous alternate narrow entire leaves, and a terminal raceme of irregular yellow flowers. 


\begin{tabular}{|c|c|c|c|}
\hline Organ. & No. & Cohesion. & Adhesion. \\
\hline $\begin{array}{l}\text { Calyx. } \\
\text { sepals. }\end{array}$ & 5 & Gamosepalous. & Inferior. \\
\hline $\begin{array}{l}\text { Corolla. } \\
\text { petals. }\end{array}$ & 5 & Gamopetalous. & Hypogynous. \\
\hline Stamens. & 4 & Didynamous. & Epipetalous. \\
\hline $\begin{array}{l}\text { Pistil. } \\
\text { carpels. }\end{array}$ & 2 & Syncarpous. & Superior. \\
\hline Seeds. & \multicolumn{3}{|c|}{ Indefinite in each cell of the capsule. } \\
\hline
\end{tabular}

OBSERVE the spurred corolla of Linaria; there

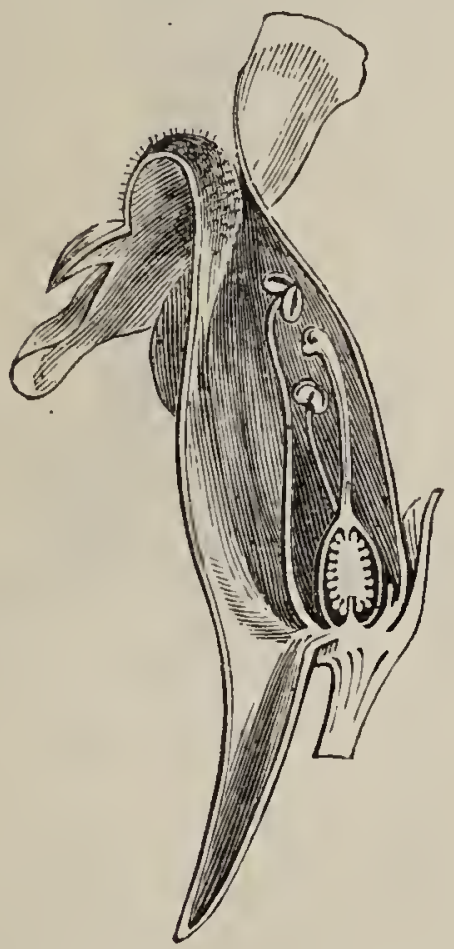

Fro. 12S. Vertical section of flower of Common Linaria, showing the spur. The corolla is personate.

is normally one spur, but the corolla occasionally becomes 5-spurred and regular. Such regular 
forms of corollas, normally irregular, are termed Peloria.

Compare, as to form of corolla :- Speedwell (Veronica), in which it is 4-partite, nearly regular and rotate; Mullein (Verbascum), 5-partite and rotate; Foxglove (Digitalis), inflated, tubular; Snapdragon (Antirrlinum), bilabiate and personate; Lonsewort (Pedicularis), bilabiate and ringent (gaping); Garden Calceolaria, calceolate or "slipper-shaped."

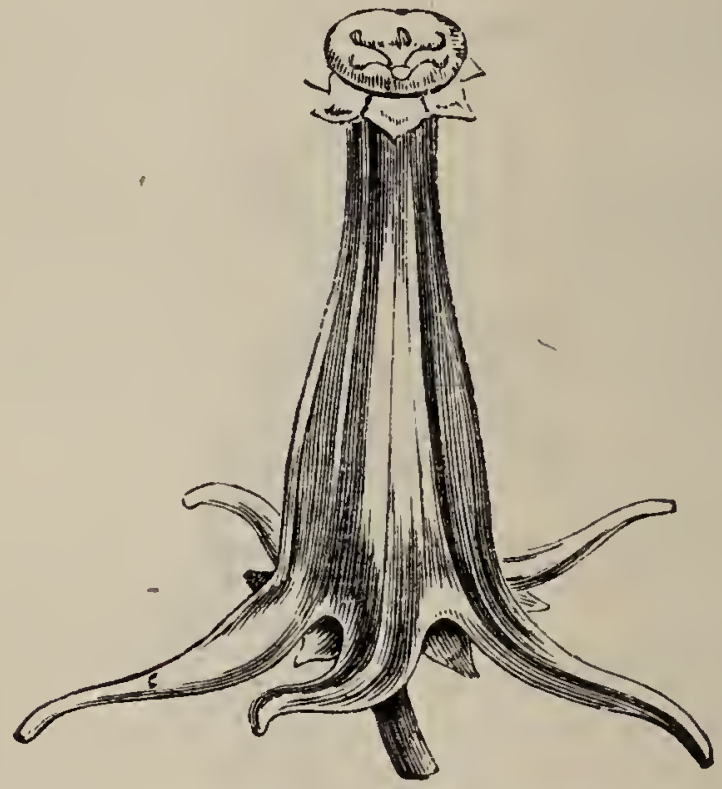

Fig. 129. Monstrosity (Peloria) of Common Linaria, in which 5 spurs are developed, so that the corolla is regular.

Compare, as to number of stamens :- Speed well, diandrous ; Linaria, didynamous ; Scrophularia, also didynamous, with a rudimentary fifth stamen (staminode); Mullein, pentandrous.

A partial parasitism occurs in some species allied to the Rattle (Rhinanthus) and Eyebright (Euphrasia), as may be ascertained by carefully 
washing away the soil from the roots. When raised from seed, apart from the plants upon which they prey, 1hough capable of germination they do not grow more than an inch or so in height, and produce but one or two flowers. It is not precisely ascertained what amount or kind of nourishment the nurse-plants yield. Cow-wheat (Melampyrum), Eyebright, Bartsia, and Rattle are suited to experiment upon with a view to further information.

'The family includes very few useful plants, though many are highly ornamental and common in cultivation, as Calceolaria, Pentstemon, Snapdragon, Monkey-flower and Musk (Mimulus), Speedwells, \&c. Foxglove is very poisonous, and is used in medicine; a yellow dye is obtained from Common Linaria and from some Calceolarias.

48. Natural Order-Labiata. The Labiate Family.

DistRiBuTION.-Numerous in every quarter of the globe; especially so in proportion to other Natural Orders in the Mediterranean region.British genera 18, species 44 .

Herbs. Corolla irregular. Stamens fewer than corollalobes. Ovary 4-lobed, style from between the lobes.

Type-White Lamium (Lamium album). (Dearlnettle.)

A coarse perennial herb, with square stem, opposite exstipulate leaves, and axillary cymes (forming verticillasters) of bilabiate white flowers. 


\begin{tabular}{|c|c|c|c|}
\hline Organ. & No. & Cohesion. & Adhesion. \\
\hline $\begin{array}{l}\text { Calyx. } \\
\text { sepals. }\end{array}$ & 5 & Gamosepalous. & Inferior. \\
\hline $\begin{array}{l}\text { Corolla. } \\
\text { petals. }\end{array}$ & 5 & Gamopetalous. & Hypogynous. \\
\hline Stamens. & 4 & Didynamous. & Epipetalous. \\
\hline $\begin{array}{l}\text { Pistil. } \\
\text { carpels. }\end{array}$ & 2 & Syncarpous. & Superior. \\
\hline
\end{tabular}

OBSERve the square stem and invariably opposite leaves of the Order, which derives its name from the characteristic form of the corolla of its members. It is irregular and usually two-lipped; hence called labiate or bilabiate.

From those Scrophulariaceæ which have a similar corolla, Labiates may be distinguished by the ovary, which is 4-lobed as in Boragineæ, each lobe with 1 ovule, and by the gynobasic style. Labiates differ from Borages in the stamens being fewer than the lobes of the corolla, and in the characters of the stem and leaf referred to above.

Observe, also, the stamens of Sage (Salvia), remarkable for the great length of the connective, - the portion of the anther connecting the pollencontaining lobes. In Labiatre the connective is usually dilated, so that the anther-lobes, instead of being parallel, are divergent at the base, or even in a straight line, as in White Lamium; but in Salvia this dilatation is carried to such an excess that the connective becomes much longer than the filament, for which it is apt to be mistaken. One of the anther-lobes is more or less abortive. 
None of the Order is hurtful, and many species are aromatic, from the presence of essential

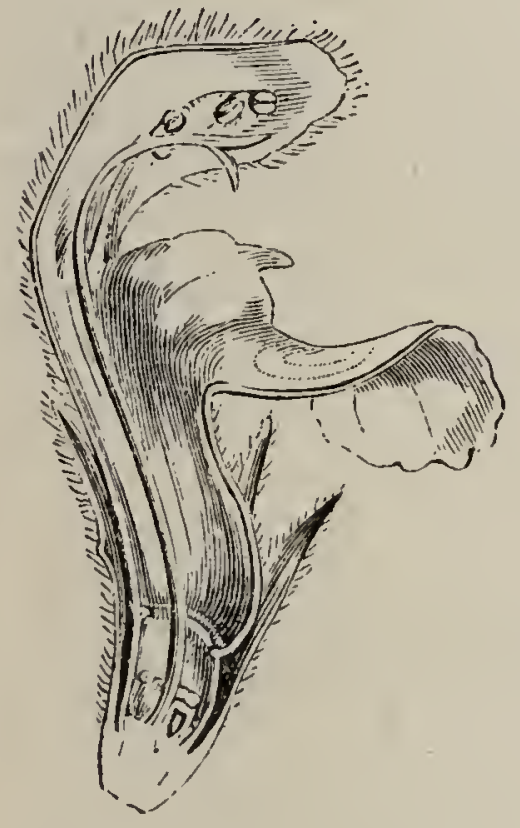

Fis. 130. Vertical section of bilabiate flower of White Lamium.

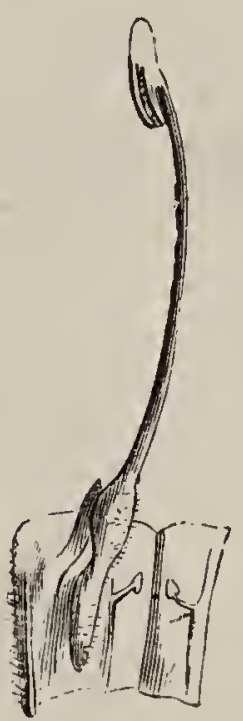

Fig. 131. Epipetalous stamen of Sage, showing the very short filament and long (dis. tractile) connective. The lower anther-lobe is abortive. Rudiments of two suppressed stamens are also shown.

oil contained in glands immersed in the tissue of the leaves. The oil may be separated by distillation. In this way Oils of Peppermint, Lavender, Thyme, and Rosemary are obtained. Lavender water is prepared by dissolving the Oil of Lavender in spirits of wine. Many Labiates are valuable kitchen-herbs, as Mint (Mentha), Penny-royal (Mentha Pulegium), Marjoram (Origanum), Thyme (Thymus), Sage (Salvia), Basil (Ocymum), Savory (S'atureia), and Balm (Melissa). 
49. Natural Oider-Verbenaces. The Ver. vein Family.

Distribution. - Chiefly tropical and subtropical in both hemispheres.-One British genus, species 1.

Type-Common Vervein (Verbena officinalis).

An erect perennial herb, with opposite toothed teaves, and small flowers in terminal slender spikes.

\begin{tabular}{|c|c|c|c|}
\hline Organ. & No. & Cohesion. & Adhesion. \\
\hline $\begin{array}{l}\text { Calyz. } \\
\text { sepals. }\end{array}$ & 5 & Gamosepralous. & Inferior. \\
\hline $\begin{array}{l}\text { Corolla. } \\
\text { petals. }\end{array}$ & 5 & Gamopetalous. & Hypugynous. \\
\hline Stamens. & 4 & Didynamous. & Epipetalous. \\
\hline $\begin{array}{l}\text { Pistil. } \\
\text { carpels. }\end{array}$ & 2 & Syncarpous. & Superior. \\
\hline Seeds. & \multicolumn{3}{|c|}{ Solitary in each cell of the fruit. } \\
\hline
\end{tabular}

Ouserve the corolla and didynamous stamens, as in Labiates, associated with a 4-celled, consolidated or entire ovary with a terminal style.

The Family is represented by a solitary species in Britain, referred to here principally because of its close affinity to Labiates.

Very few species are of economic importance. The Teak (Tectona grandis), an Indian forest-tree, furnishes a most valuable timber, used in ship and railway-carriage building.

Several Verbenaceæ are highly ornamental and favourite garden and hot-house plants, including the garden Verbenas,-cultivated varieties of one or two South American species. 
50. Natural Order-Plumbagineæ. The Plumoago Family.

Distribution.-Affecting maritime, saline, or alpine situations, principally of temperate regions of the Old World.-British genera 2, species 5 .

Herbs. Styles 5. Ovary 1-celled.

Type-Common Thrift (Armeria vulgaris).

A low perennial, with tufted woody stock, rosulate linear leaves, and pedunculate capitate Howers.

\begin{tabular}{|l||r|l|l|}
\hline \multicolumn{1}{|c|}{ Orgun. } & No. & \multicolumn{1}{c|}{ Cohesion. } & \multicolumn{1}{|c|}{ Adhesion. } \\
\hline $\begin{array}{l}\text { Calyx. } \\
\text { sepals. }\end{array}$ & 5 & Gamosepalous. & Inferior. \\
\hline $\begin{array}{l}\text { Corolla. } \\
\text { petuls. }\end{array}$ & 5 & Polypetalous. & Hypogynous. \\
\hline $\begin{array}{l}\text { Stanens. } \\
\text { Pistil. }\end{array}$ & -5 & Pentandrous. & Hypogynous. \\
\hline $\begin{array}{l}\text { carpels. } \\
\text { Seeds. }\end{array}$ & Syncarpous. & Superior. \\
\hline
\end{tabular}

N.B.-The petals may be found slightly cuhering, and the stamens adherent to the base of the petals, to which they are opposite.

OBserve the 1-celled ovary, with 5 styles, containing a single, suspended ovule.

51. Natural Order-Plantagineæ. The Plantain Family.

Distribution. - A small widely-dispersed Order.-British genera 2, species 6 .

Herbs. Calyx polysepalous (scpals 4). Corolla 4-lobed. Stamens 4. Style 1. Ovary 1-2-4-celled. 
Type-Greater Plantain (Plantago major).

Herb, with tufted broad radical leaves, and long pedunculate spikes of small greenish flowers.

\begin{tabular}{|c|c|c|c|}
\hline Organ. & No. & Cohesion. & Adhesion. \\
\hline $\begin{array}{l}\text { Calyx. } \\
\text { sepals. }\end{array}$ & 4 & Polysepalous. & Inferior. \\
\hline $\begin{array}{l}\text { Corolla. } \\
\text { petals. }\end{array}$ & 4 & Ganopetalous. & Hypogynous. \\
\hline Stamens. & 4 & Tetrandrous. & Epipetalous. \\
\hline $\begin{array}{l}\text { Pistil. } \\
\text { carpels. }\end{array}$ & 2 & Syncarpous. & Superior. \\
\hline Seeds. & 4 to & in each cell of & le capsule. \\
\hline
\end{tabular}

Observe the dry and membranous (scarious) corolla : the transverse dehiscence of the capsule.

Some of the species are subject to a monstrous condition of the inflorescence, the bracts becoming foliaceous, or flowering branches being substituted for some of the flowers.

The seeds of Greater Plantain are a favourite food of cage-birds ; Ribwort Plantain ( $P$. lanceolata) is a common plant of pastures.

Sub-class. Incompletæ. Division. Monochlamydeæ.

52. Natural Order-Chenopodiaceæ. The Groosefoot Family.

Distribution.-Generally diffused through both hemispheres, though many of the genera affect saline situations, especially in Temperate Asia -British genera 6, species 19. 
Herbs. Stipules 0. Stamens opposite to the perianth. segments. Ovary 1 -celled with 1 erest ovale.

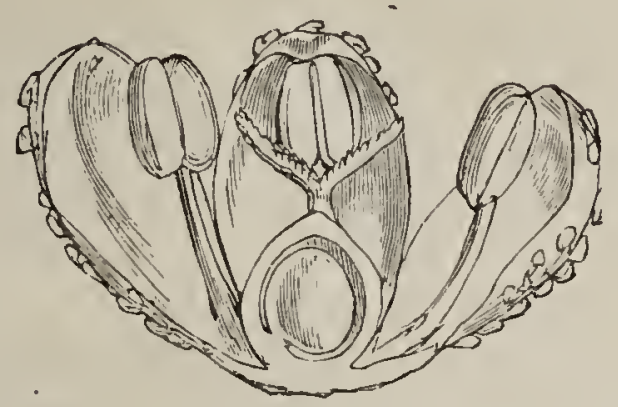

Fia. 132. Vertical section of Hower of Goosefoot (Chencpodium).

Type-White Goosefoot (Chenopodium album).

An erect somewhat mealy annual, with alternate toothed or entire leaves, and dense interrupted spikes of small green fluwer's.

\begin{tabular}{|l||c|l|l|}
\hline \multicolumn{1}{c|}{ Organ. } & No. & \multicolumn{1}{c|}{ Cohesion. } & \multicolumn{1}{c|}{ Adhesion. } \\
\hline $\begin{array}{l}\text { Perianth. } \\
\text { leaves. }\end{array}$ & 5 & Gamophyllous. & Inferior. \\
\hline \begin{tabular}{l} 
Stamens. \\
\hline
\end{tabular} & Pentandrous. & Epiphyllous. \\
\hline $\begin{array}{l}\text { Pistil. } \\
\text { carpels. }\end{array}$ & 2 or 3 & Syncarpous. * & Superior. \\
\hline \begin{tabular}{l} 
Seeds. Solitary, albuminous, with a curved embryo. \\
\hline
\end{tabular}
\end{tabular}

OBSERVE the 2 accrescent (enlarging after flowering) bracteoles, replacing the perianth in the pistillate flowers of Orache (Atriplex): the stamens opposite to the segments of the perianth in the type.

* When there is 110 indication in the fully-grown pistil of the number of carpels which compose it, its apocarpous or syncarpous nature may be ascertained by a study of its development; if syncarpous, the carpels being congenitally coherent. 
Sereral species are cultivated, as Mangold Wurzel and Beet, both varieties of Beta vulgaris, an herb growing wild on our shores. In France and Central Europe Beet is extensively cultivated for the sake of the sugar contained in the saccharine juice of the root. One tun of Liet rout is reckoned to afford 100 lus. of law or $55 \mathrm{lbs}$. of retined sugar.

Garden Spinach is Spinacia olerecerr. Wild Good-King-Henry (Chenopodium Bonus-Henricus) and Garden Orache (Atriplex hortensis) are also used as pot-herbs.

The mealy seeds of $C$. Quinoa form an important article of food on the slopes of the Peruvian and Chilian Andes, but it is said to be less productive than Buckwheat (Polygonum I'agopyrum). Artificial Shagreen used to be made by pressing a piece of leather upon the seeds of White Goosefoot so as to raise a warted surface.

From the ash (called Barilla) of species comtion upon the sea-shore, as Glasswort (Salicornic herbacea) and Saltwort (Salsola Kali), carbonate of soda used formerly to be obtained.

53. Natural Order-Polygonacea. The Pulygounum Family.

Distarbution.-In both hemispheres, from the Arctic zone to the Equator.-British grenera 3, species 22.

Herbs with sheathing stipules. Ovaly 1-celled with 1 erect ovule.

'Type-Bistort Polygonum (Polygonum Bistorta). 
Herb with perennial stock, jetiolate radical leaves, and erect simple stems bearing dense terminal spikes of pale pink flowers.

\begin{tabular}{|c|c|c|c|}
\hline Organ. & No. & Cohesion. & Adhesion. \\
\hline $\begin{array}{l}\text { Perianth. } \\
\text { leaves. }\end{array}$ & 5 & Gamophyllous. & Inferior. \\
\hline Stamens. & 8 & Octandrous. & Epiphyllous. \\
\hline $\begin{array}{l}\text { Pistil. } \\
\text { carpels. }\end{array}$ & 3 & Syncarpous. & Superior. \\
\hline Seeds. & \multicolumn{3}{|c|}{ Solitary in a 1-celled nut. } \\
\hline
\end{tabular}

OBserave the sheathing, membranous stipules characteristic of the Order: the trimerous syntinetry (characteristic of Monocotyledons) of Rhubarb (Rheum) and Dock (Rumex), and the enlargement of the 3 inner segments of the perianth after flowering, in these genera : the diocious Howers of Sheep-sorrel (Rumex Acetosella and $R$. Acetosa).

Rhubarb of greengrocers is the succulent acid petiole of a species of Rheum. Eastern species of the same genus afford the root used in medicine as Rhubarb.

Buckwheat (Polygonum Fagopyrum) has been long cultivated in temperate countries for its farisaceous seeds, of which a useful bread is made. It in planted in England for feeding game and poultry.

54. Natural Order-Thymelaceæ. The Daphne Family.

Distribution.-Chiefly confined to the old World, and most numerous in Australia and at the Cape of Good Hope.-One British genus, species 2.

Shrubs. Ovary 1-celled, with 1 pendulous ovule. 
Type-Spurge Daphne (Daphne Laureola.)

An erect little-branched shrub, with shining evergreen entire leaves, and clustered greenish flowers.

\begin{tabular}{|c|c|c|c|}
\hline Organ. & No. & Cohesion. & Adhesion. \\
\hline $\begin{array}{l}\text { Perianth. } \\
\text { beaves. }\end{array}$ & & Gamophyllous. & Inferior. \\
\hline Stamens. & $\delta$ & Octandrous. & Epiphyllous. \\
\hline $\begin{array}{l}\text { Pistil. } \\
\text { carpels. }\end{array}$ & 1 & Apocarpous. & Superior. \\
\hline
\end{tabular}

OBSERve the tenacious liber-layer of the bark: characteristic of the Family: the highly-coloured perianth of some garden and greenhouse genera.

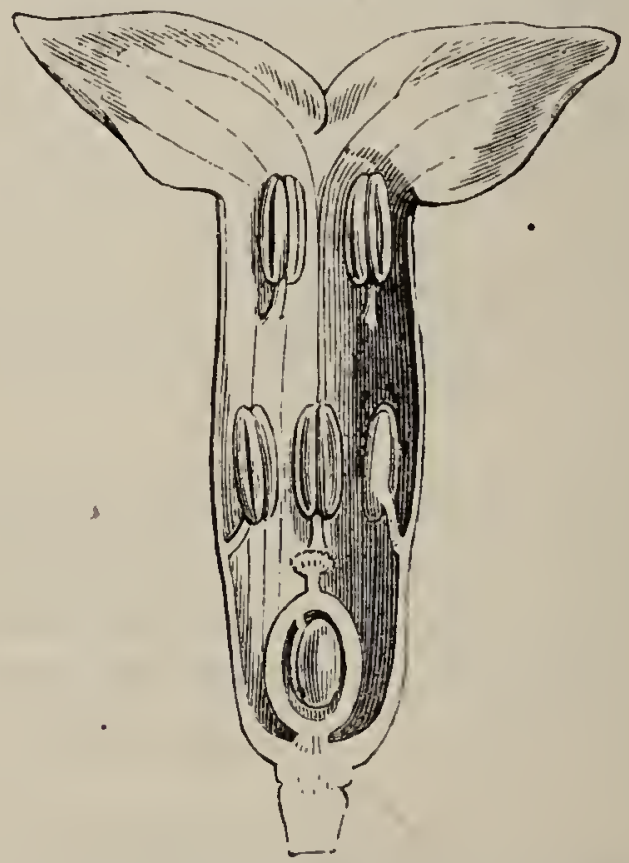

Yic. 133. Vertical section of nower of Spurge Dapisue.

The berries of Mezereon (D. Mezereum) are poisonous, and those of Spurge Daphne are also 


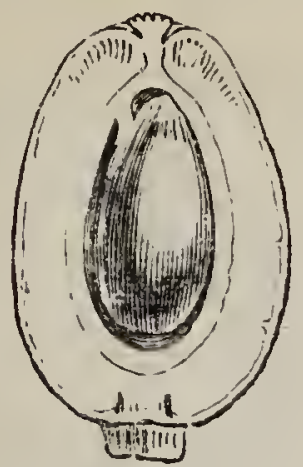

fina. 134. Vertical section of fruit of same, showing a solitary suspended seed.

said to be poisonous to all animals excepting birds. From the liber of $D$. papyracea of the Himalaya a coarse, but very tough, paper is made. Lagetta lintearia is the Jamaica Lacebark tree, the liber of which may be separated into many thin layers resembling lace, by maceration. It is made up into various ornamental articles.

55. Natural Order - Euphorbiaceæ. The Spurge Family.

Distribution. - A very large Natural Order, widely dispersed in both hemispheres; most numerous in tropical and subtropical regions. British genera 3, species 15 .

Herbs, usually with milky juice, or an evergreen shrub. Ovary 3-celled (2-celled in Mercury).

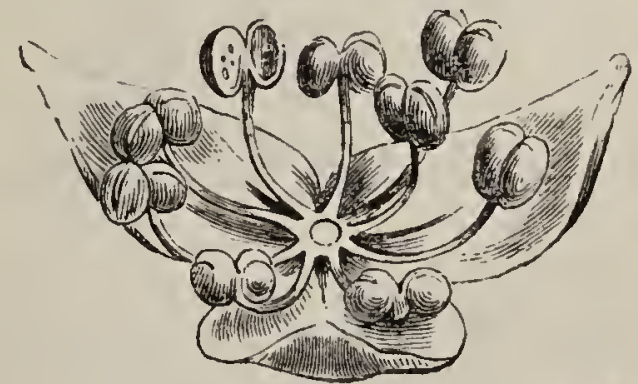

Fra. 135. Stammate llower of Peremiat Mercury. 


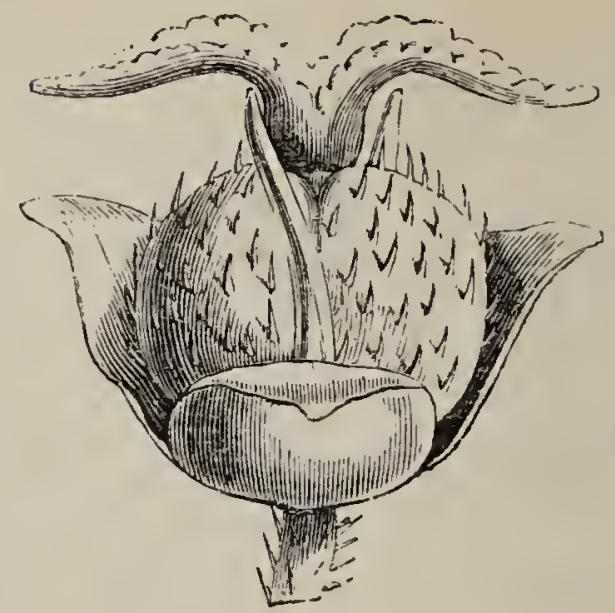

Fic. 136 Pistillate flower of silne, with 11 o imper ect stuitens

Type-Perennial Mercury (Mercurialis perennis).

An herbaccous perennial, with opposite simple leaves, and d'œcious axillary loosely spicate flowers.

\begin{tabular}{|c|c|c|c|}
\hline Organ. & No. & Cohesion. & Aclhesion. \\
\hline $\begin{array}{l}\text { Perianth. } \\
\text { leaves. }\end{array}$ & 3 & Polyphyllous. & Inferior. \\
\hline o, Stamens. & $9-12$ & Enne-Dodecandrous. & Hypogynous. \\
\hline$\delta$, Pistil. & 0 & 0 & 0 \\
\hline q, Stamens. & 0 & 0 & 0 \\
\hline $\begin{array}{l}\text { q, Pistil. } \\
\text { carpels. }\end{array}$ & 2 & Syncarpous. & Superior. \\
\hline Seeds. & One i: & eaeh cell, albuminous & \\
\hline
\end{tabular}

N.B.-In the pistillate flowers there are two filaments, but no anthers.

Most of the British species of the Order belong to a distinct type, the genus Spurge (Euphorbia), characterised by achlamydeous, monœeious fluwer's. 


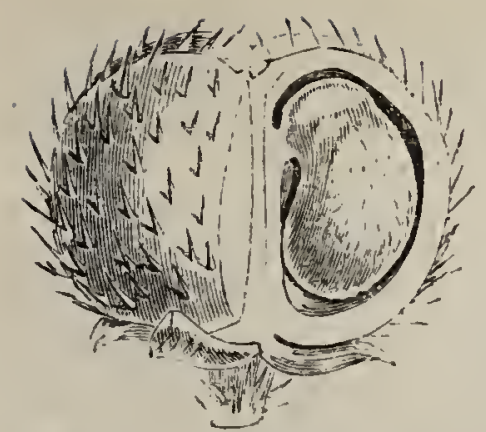

Fio. 137. Jicoccous fruit of Priennial Mercury, the pericarp of one carpel partially removed so as to show the sced.

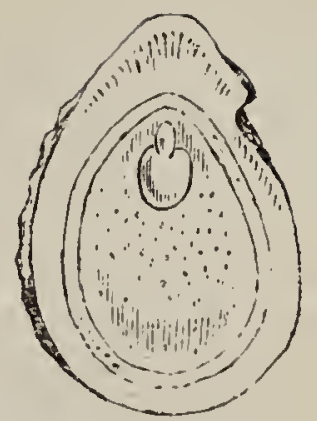

Fı. 13S. Longitulinal section of albuminous seet of samo. The radicle is superior.

The staminate fluwers are monandrous, and the ovary of the pistillate flower consists of 3 carpels. One pistillate and several staminate flowers are collected within a small involucre, bordered by marginal "glands," which may be mistaken by begimmers for petales or calyx-lubes. A joint

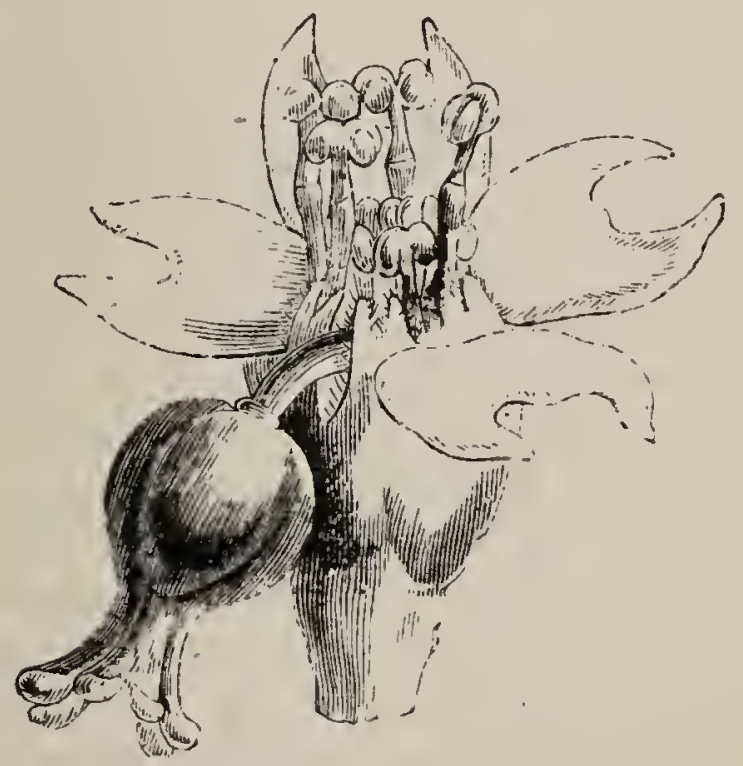

Fic. 1:39. Involucre of Sillrge, burdered by fonr horned "glinds," and containing numerous male Howers and one female. The pedicel of the latter is curved over the side of the involucre. 
some distance below the anther of each staminate flower indicates the point where the filament joins the pedicel. At this node, in an allied genus, a partial perianth is developed.

OBSERve the milky juice of the Spurges ( $E u$ phorbia), which is dangerously poisonous in some species, and is used by barbarous African tribes to poison their weapons. The milk of Siphonia Brasiliensis, a Brazilian tree, yields the best Caoutchouc exported from Brazil. It flows from wounds in the bark, and is allowed to dry over moulds of clay, the clay being washed out when the "India rubber" is sufficiently stiffened. Upwards of 145,000 cwts. of Caoutchouc were imported into the United Kingdom in 1868. It must be borne in mind, nowever, that this product is afforded by several other plants besides Siphonia: especially by a species of Fig (Ficus) in India.

Gutta Percha is the similar product of an Indian tree belonging to an Order (Sapotaceæ) not represented in Britain. Upwards of $25,000 \mathrm{cwts}$. of Gutta Percha were imported in 1871 .

Cassava, or Mandiocca Meal, an important article of food in the Tropics, especially of South America, is afforded by species of Manihot. The juice of one of the Cassava-producing species (M. utilissima) is a virulent poison : this is removed from the root by washing, after it has been grated. Tapioca is the fine starch which settles down from the water used to wash Cas. sava. It is granulated upon hot plates. The roots of the Bitter Cassava weigh from 30 lbs. to 40 lbs., and the crop is said to be one of the most productive yielded by any food-plant. 
Several species afford important drugs, as Castor Oil, obtained from the seeds of Ricinus, and Croton

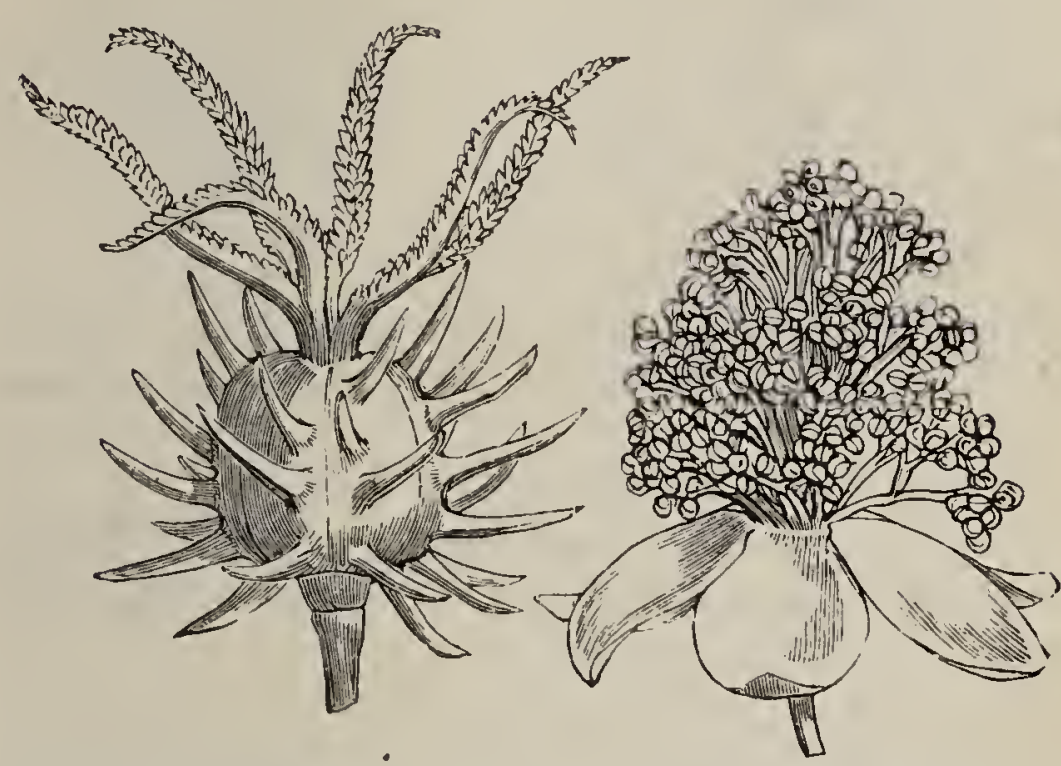

FIG. 140. Pistillate flower of ricinus communis.
Fıo. 141. Staminate flower of same.

Oil, from the seeds of Croton Tiglium. African Teak (Oldfieldia) and the Box (Buxus) yield valuable wood; the latter furnishing the blocks used by wood-engravers, for whose purposes its close texture and hardness eminently fit it. It is native in South and South-Eastern Europe, and grows in some wild situations in England, but it may have been introduced long ago to the latter.

56. Natural Order-Urticacex. The Natile Family.

Distribution.-Cosmopolitan, but most numerous between the Tropics.-British genera 3, species 5 . 
Stinging herbs. Flowers unisexual. Uvary 1-celled. with 1 erect orule.

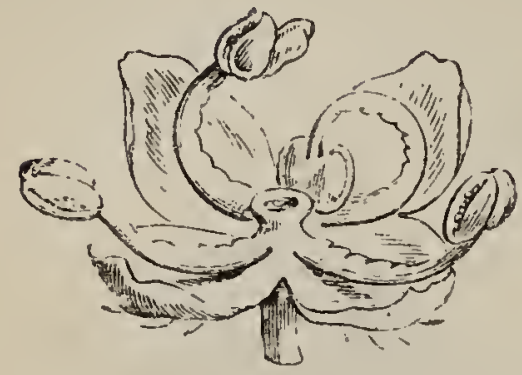

F:: 142. Staminate flower of simall Nettle.

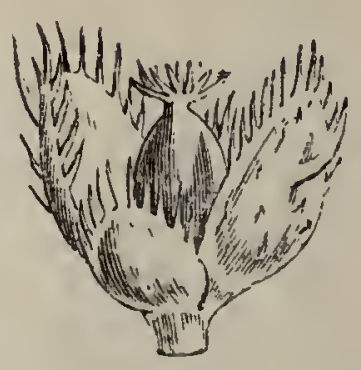

F1r. 14:3. Pistillatc flower or sinue.

Type-Small Nettle (Urtica urens).

An annual herb, with opposite simple leaves, stmgnty hair's, and axillary clusters or spikes of small moncecious f́lower's.

\begin{tabular}{|c|c|c|c|}
\hline Organ. & No. & Cohesion. & Adihesion. \\
\hline $\begin{array}{l}\text { Periantll. } \\
\text { leaces. }\end{array}$ & 4 & Polyphyllous. & Inferiur. \\
\hline 3, Stamens. & 4 & Tetrandrous. & Hypogyuous \\
\hline s. Pistil. & 0 & 0 & 0 \\
\hline 9. Stamens. & 0 & 0 & 0 \\
\hline $\begin{array}{l}\text { 7, Pistil. } \\
\text { carpel. }\end{array}$ & 1 & Apocarpous. & Superior. \\
\hline
\end{tabular}

Orsfrve the stamens opposite to the leaves of the perianth, and their elastic filaments, flyine hack when released by the expansion of the Hower.

The bark of some species of the Nettle Family affurds an invaluable fibre, especially that of the Ilemp plant (Cannabis sacroa), which has becu 


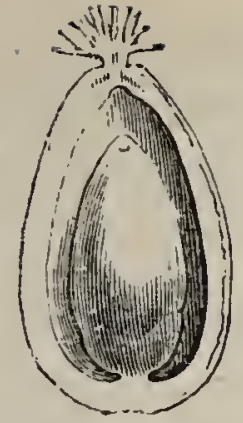

Fia. 144. Longitudinal section of fruit of Small Nettle.

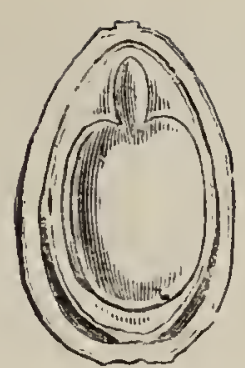

F1G. 145. Section of seed of same, showing the large einbryo, with a superine radicle and but little albunien.

cultivated from a remote period, in temperate climates, for its fibre. It is recorded as having been under culture 2,500 years ago. The fibre is obtained in the same way as Flax. In India, Hemp is grown chiefly for the sake of a narcotic, intoxicating gum-resin, called Churras, exuded by the leaves and stem. The dried leaves and twigs are smoked.

Chinese Grass-cloth fibre is yielded by a stingless Nettle of Eastern Asia (Boehmeria nivea).

The Hop (Humulus Lupulus) is remarkable amongst the Nettle Family for its twining stem. The bracts of the inflorescence become enlarged under cultivation and covered with minute glands, containing a bitter gum-resin (allied to the Churras of Hemp), which is used to impart flavour and a preserving quality to beer.

Other important exotic species belonging to Urticaceæ in its widest sense are :-

Mulberry (Morus nigra and $M$. alba), the leaves of which furnish the food of the silkworm. It is grown extensively both in the South of Europe and in Asia. The fruit ought to be carefully examined. Although resembling a cluster of 
drupels when ripe, as in Blackberry, it is an aggregation of several fruits, as explained previously (page 99).

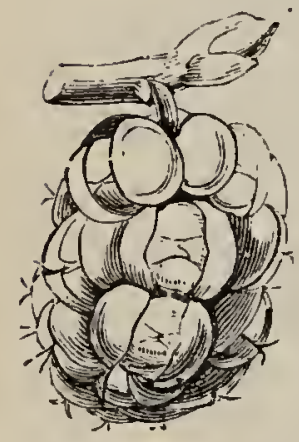

FIG. 146. Collective Fig. 147. Fistillate fruit of ifulberry.

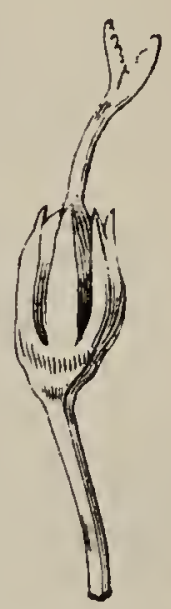

flower of Fig.

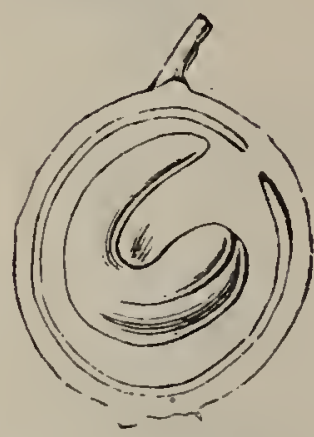

Fla. 1+\&. Jongitr. dinal section of achene and albumi. nous seed of Fig.

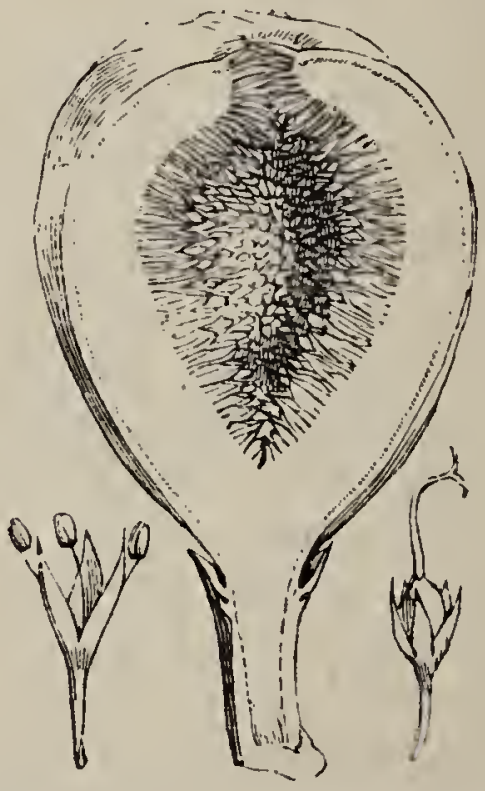

Fıa 149. Section of common Fig (Ficus (arica), showing the orowded minnte fiowers lining the linllow recentacle. To the left, a detached staminate flowar; to t'le right, a pistillate flower. 
'The Paper Mulberry (Broussonetia papyrifera) furnishes to the Polynesian Islanders the useful Tapa cloth, which is fabricated from its fibrous bark by beating and scraping. The cloth is stamped with patterns in various colours.

The Fig (Ficus Carica), the familiar fruit of which is described at page 100. Some Eastern species afford Indiarubber, as $F$. elastica. $I$. indica is the celebrated Banyan tree, remarkable for the enormous extension of its crown by means of adventitious roots which are thrown down from the boughs. A single tree may thus cover many acres.

Bread-fruit, the staple food of the South Sca Islanders, is yielded by Artocarpus incisa.

The celebrated Upas (Antiaris toxicaria), of which absurd stories were believed a century ago, is a native of Java. The juice is poisonous, and was formerly used by the natives to poison their arrows, but the statements of the effect produced upon creatures approaching the tree are fabulous.

57. Natural Order-Ulmaceæ. The Eln) Order.

Distribution.-A very small Order, nearly confined to the North Temperate Zone, though common to both hemispheres. - One British genus, species 2.

Trees. Flowers perfect. Ovary 2-celled. Fruit winged.

Type-Wych Elm (Ulmus montana).

A large deciduous tree, with alternate simplo 
roughish leaves, precocious hermaphrodite flowers, and winged fruits.

\begin{tabular}{|c|c|c|c|}
\hline Organ. & No. & Cohesion. & Adhesion. \\
\hline $\begin{array}{l}\text { Perianth. } \\
\text { leaves. }\end{array}$ & 5 & Gamophyllous. & Inferior. \\
\hline Stamens. & 5 & Pentandrous. & Epipliyllous. \\
\hline $\begin{array}{l}\text { Pistil. } \\
\text { carpels. }\end{array}$ & 2 & Syncarpous. & Superior. \\
\hline Seeds. & \multicolumn{3}{|c|}{ Solitary, pendulous. } \\
\hline
\end{tabular}

The ovary is 2-celled, but one cell is suppressed a: the fruit matures.

The timber of old Pollard Elms is valuable for ornamental cabinet-work, on account of the knots in the wood, due to numerous arrested adventitious buds. The wood of English Elm is suited for works which are constantly wet.

58. Natural Order-Corylacæ. The Hazel Family.

Distribution. - Principally confined to the North temperate zone, and the mountain ranges of intertropical countries of both hemispheres, Africa excepted.-British genera 4, species 4 .

Trees. Flowers monœcious. Ovary inferior. Fruit 1.celled, 1-seeded.

Type-Common Hazel (Corylus Avellana).

A low deciduous tree, with monocious flowers (the male in catkins) appearing before the alternate simple stipulate leaves. Fruit, a nut. 


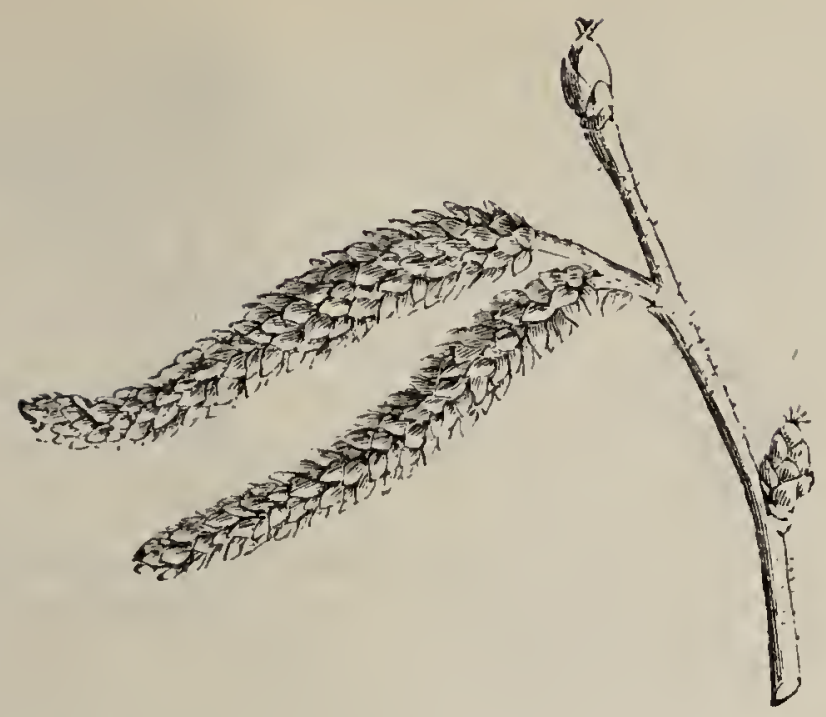

Frg. 150. Moncecious inflorescence of Common Hazel. The sta. minate flowers are in catkins, the pistillate flowers in snall heads.

\begin{tabular}{|c|c|c|c|}
\hline Organ. & No. & Cohesion. & Adhesion. \\
\hline $\begin{array}{l}\text { क, Perianth. } \\
\text { leaves. }\end{array}$ & $?$ & Gamophyllous. & Superior. \\
\hline o, Stamens. & 8 & Octandrous. & \\
\hline $\begin{array}{l}\text { 9, Pistil. } \\
\text { carpels. }\end{array}$ & 2 & Syncarpous. & Inferior. \\
\hline Seeds. & Solit & ry, exalbuminor & \\
\hline
\end{tabular}

N.B.-The male flowers are arranger in pendulous catkins, each flower consisting (apparently) of 8 stamens inserted in the axil of minute bractscales.

The female flowcrs are collected in small heads surrounded by several scale-Jike bracts, from which the crimson stigmas project in early spring. The pollen is conveyed to these, but the ovules are stated not to be formed until some weeks later. 


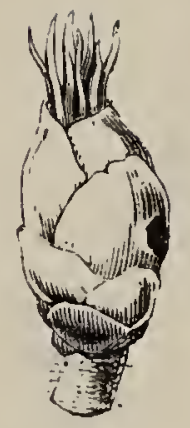

F!G. 151. Head of pistillate Howers of Corumor Hazel.

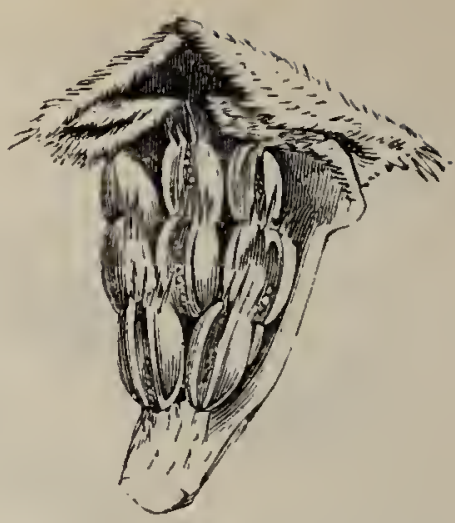

F1a. 152. Sistle from eatkin of male Howers of same, bearillg 2 smaller scales and $\$$ stamens in its axil.

Corylaceæ, together with Salicaceæ and Betulaceæ, are grouped together by some botanists in a single Family called Amentacer, on account of their characteristic form of inflorescence, especially of the staminate flowers, which are arranged in catkins or aments, that is, in spikes which fall away when thr flowers are withered or the fruit has ripened.

ObSERve the limb of the peri- Fig. 153. Trausanth of the female flower, usually reduced to very minute teeth, sur-

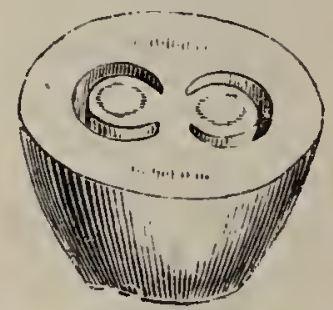
?-celled ovary of Hazel. rounding the base of the styles: in some species, as the Hazel, it is almost obsolete. Note, also, the usual abortion in the Order of all the cells of the ovary excepting one, so that the iruit is 1-celled, and contains but a single seed, as the Acorn of the Oak, Chestnuts: Hazel-nuts, and Beech-nuts.

Compare the cupule (involucro) of Oak (Quer. 
cus), consisting of numierous minute consolidated bracts, containing a single fruit; Beech (Fagus), separating into 4 valves, and containing 2 fruits; Chestnut (Castanea), spinose, with 3 or more fruits; Hazel (Corylus), consisting of about 2 leafy accrescent bracts, which overtop the single nut; and Hornbeam (Carpinus), a 3-lobed bract, subtending a single nut. Compare, also, the fruit of Chestnut with the seed of Horse Chestnut (Esculus, page 162).

The Family of Corylaceæ is of high importance from the valuable timber-trees which it includes. Foremost amongst them is the Oak (Quercus Robur), the wood of which is more tenacious, elastic, and durable than that of any other indigenous tree. Its bark abounds in astringent principles, which render it valuable for tanning purposes, the tamnin of the bark uniting with the gelatine of hides to constitute leather. The acorncups (cupules) of the Valonia Oak (Q. AEgitops) are also very astringent, and are imported in larce quantities for the use of tanners and dyers. In $1871,27,706$ tons were imported. From the gallic acid contained in the wood, the timber of the Oak is apt to become black when immersed in water containing salts of iron, which, combining with the gallic acid, form a natural ink. Hence the frequent blackness of bog Oak, and the black stains around iron nails and bolts driven into Oak timber.

Tannin and gallic acid, used in ink-making and for photographic purposes, are chiefly obtained from the galls produced upon the leaves and twigs of Q. infectoria, in Asia Minor. Similar (smaller) galls, called "oak-apples," are very common upon the leares of Common Oak. The galls are excres- 
cences, caused by the puncture of different species of Cynips, - small flies which lay their eggs beneath the epidermis, and, in some way not well understood, induce the abnormal development of tissue forming the gall.

Decaying branches of Oak are occasionally stained a verdigris green by a fungus (Peziza. ceruginosa). This stained wood is used for fancy work at Tunbridge Wells.

Two species (or rather varieties of one species) of Oak, differing in the length of time required to mature their acorns, afford cork, so largely used in making bottle-corks and bungs. The species are Q. Suber, ripening its acorns in the first season, and growing in the South of France, Spain, and Algeria, and Q. occidentalis, a native of the Atlantic side of France and Portugal. Cork is the outer bark, removed from the tree at intervals of from six to ten years after it has attained about thirty years of age. Cork previously collected is of inferior quality. The bark is heated, flattened under weights, and allowed to dry slowly. It is said that the operation of removing the cork favours the healthy growth of the tree.

Division. Achlanydeæ.

59. Natural Order-Betulacer. The Birch Family.

Dis'rribution.-Almost wholly confined to the cooler parts of the North Temperate Zone in both the Old and New World.-British genera 2, species 3 .

Trees. Flowers monœcious. Ovary superior, 2-celled. Type-Common Birch (Betala alba). 
A deciduous tree, with laminated white papery bark, slender twigs, alternate simple leaves, and amentiform inflorescence.

\begin{tabular}{|l||c|l|l|}
\hline \multicolumn{1}{c|}{ Organ. } \\
\hline o, Stamens. & $\frac{\text { No. }}{8-12}$ & $\frac{\text { Cohesion. }}{0}$ & Adhesion. \\
\hline $\begin{array}{l}\text { o, Pistil. } \\
\text { carpels. }\end{array}$ & $\frac{2}{0}$ & Synearpous. & 0 \\
\hline $\begin{array}{l}\text { Seeds. } \\
\text { Solitary in each wingel truit. }\end{array}$ \\
\hline
\end{tabular}

N.B.-Both the staminate and pistillate flowers are arranged in short cylindrical catkins. The scales of the fruit-catkins of Birch fall away from the uxis of the catkin, but in Alder (Alnus) they are wondy and remain.

This small Family includes but two genera, Birch and Alder; the former prevalent in high latitudes, penetrating beyond the Arctic circle. Birch wine is prepared by fermenting the sap, which is obtained in spring by cutting off the end of a branch and suspending a bottle to it.

The laminated bark of a Canadian species of Birch (B. papyracea) is much used for household purposes, and with the quills of the North American porcupine and dyed hair of the moose deer it is worked up into various ornamental articles by Indian tribes.

60. Natural Order-Salicaceæ. The Willow Family.

Distribution.-An Order of but two gener"a. Chiefly confined to the North Temperate Zone of both hemispheres; especially affecting Alpius and Arctic regions.-British genera 2, species 18 . 
Trees or shrubs. Flowers unisexual. Ovary superior, 1-celled, ovules basal or parietal.

Type-Sallow Willow (Salix Caprea).

A low deciduous tree, with alternate simple stipulate leaves and diocious amentaceous flowers.

\begin{tabular}{|c|c|c|c|}
\hline Organ. & No. & Cohesion. & Adhesion. \\
\hline$\delta$,Stamens. & 2 & Diandrous. & 0 \\
\hline $\begin{array}{l}\text { }, \text { Pistil. } \\
\text { carpels. }\end{array}$ & 2 & Syncarpous. & 0 \\
\hline
\end{tabular}

N.B.-Both staminate and pistillate flowers are borne in catkins, each flower in the axil of a minute scale-like bracteole. The flowers are destitute of a perianth in Willow (Salix), but in Poplar (Populus) a small perianth is present.

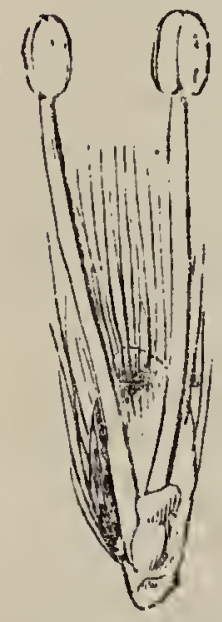

Fia. 154. Male Hower of 'Willow.

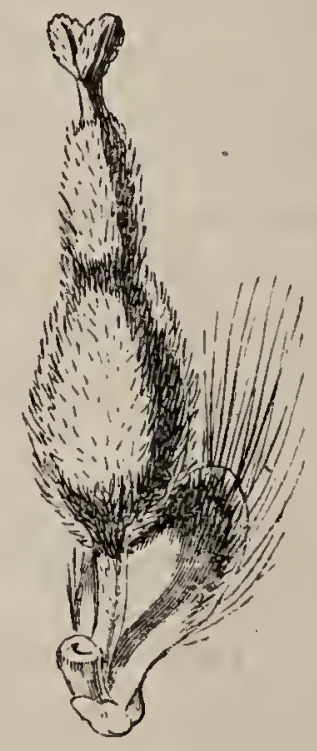

FiG. 15.5. Female flower of same.

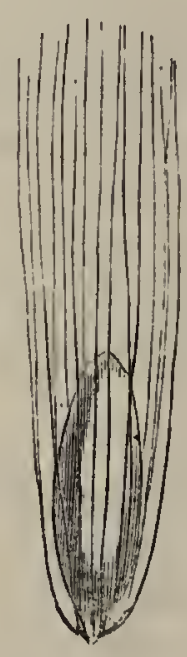

Fia 156. Seed of same. 
Onserve the l-celled ovary, parietal placentation, and the downy aril of the seeds in the Type.

Cuttings of Willow throw out adventitious roots with great freedom, and are consequently easily propagated. In this way the Weeping Willow (S. babylonica), of which only pistillate trees are in cultivation, has been widely distributed. It is supposed that all the individuals of this Willow have originated from a single parent tree.

The twigs of several species of Willow (Osiers) are used in basket-making, and from the wood of the Sallow charcoal is chiefly prepared.

61. Natural Order-Coniferæ. The Pine Family.

Distribution.-A cosmopolitan Order, with representatives from the Arctic Zone to the Equator. Several species are socially growing forest-trees, covering wide areas in the cooler parts of the North Temperate Zone.--British yenera 3, species 3 .

Evergreen trees or shrubs. Ovules naked.

Type-Scotch Fir (Pinus sylvestris).

A tall tree, with evergreen acicular geminate leaves, naked amentaceous flowers, and a multiple fruit (cone).

From the extreme simplicity of the flowers of Coniferæ, the usual schedule is not suited to exhibit their structure in a tabular form.

The male flowers of Scotch Fir are arranged in short catkins, consisting of minute, imbricating scales, each scale bearing two anther-lobes upon its under surface. 


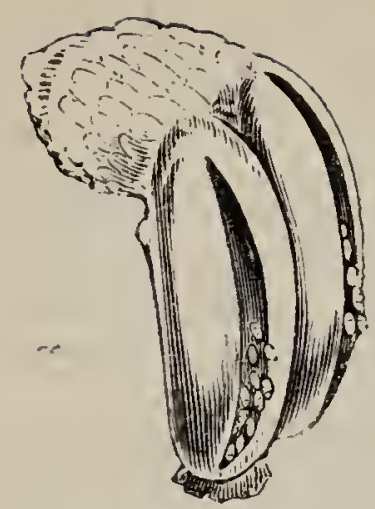

1N19. 157. Staminal scale of Scotch Fir.

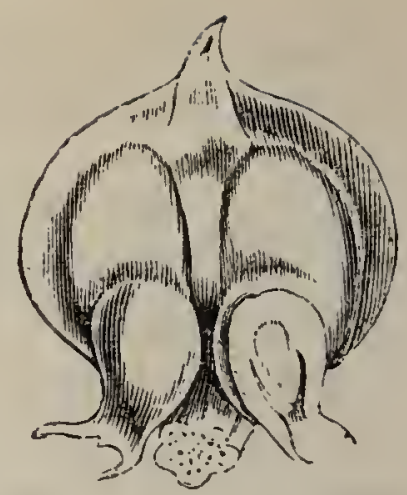

Fig. 1F8. Scale of Scotch Irirbearing ovules.

The female flowers, also, are in small, dense, cone-like catkins, consisting of small scales, each scale bearing upon the base of its upper side a pair of inverted ovules. As the scales are closely imbricated, the ovules are concealed; but they

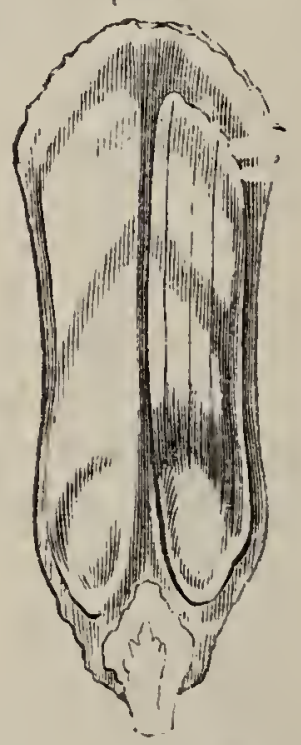

F1a. 159. Scale of ripe cont, bearing two winged seeds.

may be easily found hy breaking the flowering vone across the middle, when some of them are sure to be exposed. 
Some botanists are of opinion that the sciles to which the ovules are attached are open carpellary leaves. Their true nature is not satisfictorily settled. In any case, the ovules are naked, so that the pollen-grains fall directly upon the ovules. Hence the term Gymnospermous applied to the Family, in contradistinction to Angiospermous, applied to all other flowering plants in which the ovules are fertilized through the medium of the stigma of a carpellary leaf. In the fruit, the ovule-bearing scales are much enlarged and hard and woody in texture, each scale bearing unon the upper surface a pair of winged seeds.

The scales, both of flower and fruit, are arranged upon a common axis, in the form of a

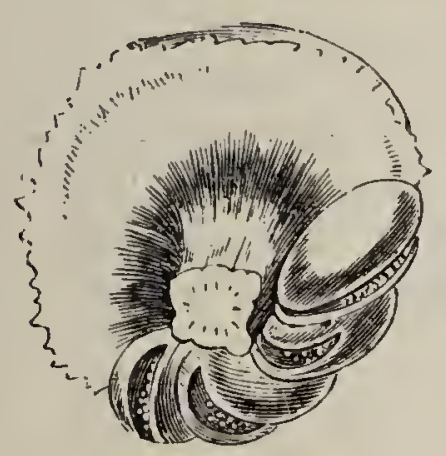

Fig. 160. Scale of $\delta$ inflorescence of Cypress.

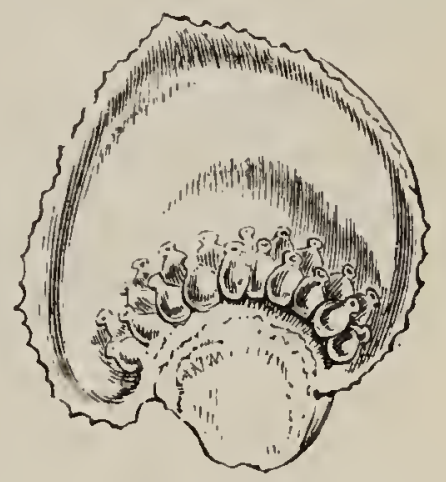

Fig. 161. Scale of $q$ inflorescence of samic.

cone: hence the name Coniferæ applied to the Pine Family.

In Cypress (Cupressus sempervirens, an exotic species), Yew (Taxus baccata), and Juniper (Juniperus communis), this Type is slightly departed from, though all agree in the naked ovules of the female flowers.

In Cypress, the scales of the male catkins bear 


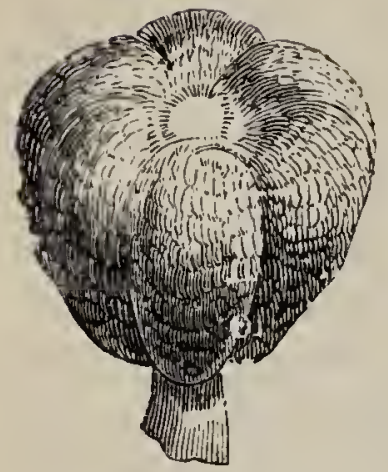

FiG. 162. Stamen of Yew.

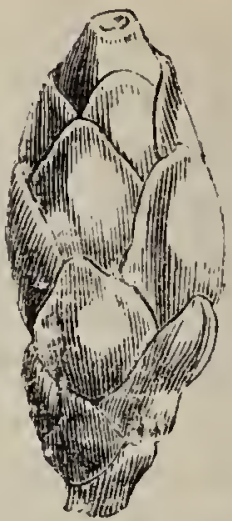

Fug. 153. Female flower of same.

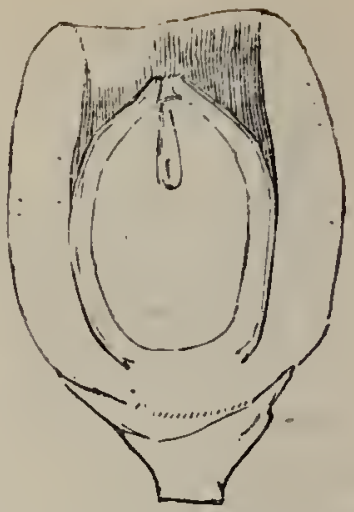

Fra. 10̉4. Vertical sec. tion of fruit of same.

4 anther-cells, and the ovnles are numerous and crect in the axils of a small number of scales arranged in a head. These scales become woody and peltate, constituting a modification of the cone, called a galbulus.

In Yew, the male flowers consist of peltate scales, bcaring about 6 (3 to 8 ) anthar-cells; the female flowers of solitary ovules, around each of which a succulent, pink-coloured disk develops as they mature, enclosing and overtopping the fruit.

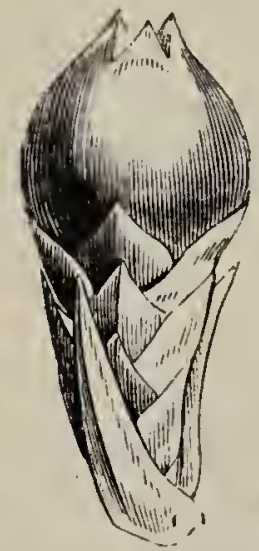

[1. 165. 우 inflorescence of $J$ uniper.

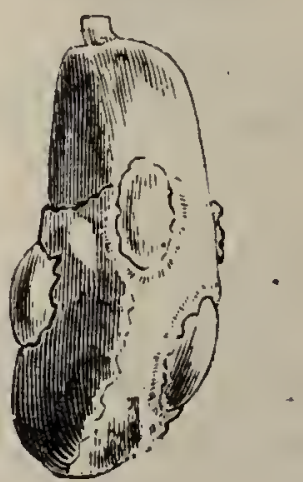

Fig. 16. Seed of same, bearing a few resin-recuptacles. 
In Juniper, the anther-scales are 4 celled, and the orules 3 in number, 1 at the base of each of 3 connate scales, which form a succulent galbulus when the seeds are ripe.

Besides the peculiarity in the structure of the female flower of Coniferæ, the Order is characterised by the absence of vessels in the wood, which consists of tapering wood-cells, marked on the sides, towards the medullary rays, with circular disks, which answer to the margins of minute, lenticular. intercellular cavities occurring between the "pits" of adjacent cells. In the Pines and allied species, the cotyledons are usually numerous, varying from 3 to 18 ; hence the term polycotyledonous applied to them. As in other respects the structure of the Coniferæ approaches that of Dicotyledons, they are usually classed along with them as an anomalous Family.

Observe, also, the different forms and the arrangement of the leaves in Coniferæ. In Scotch Fir, for example, there are two forms of leaf, viz. small, brown, scaly lcaves on the main branches the internodes of which lengthen out, and in the axil of each of these scaly leaves a single pair of long acicular leaves, sheathed at the base by scale-leaves. The long acicular leaves are borne upon axillary arrested branches.

In some other species of Pine the arrested branches bear the acicular leaves in fascicles of threes or fives.

In Larch (Larix) and Cedar (Cedrus) the acicular leaves are numerous, in dense fascicles. The former species is well adapted to show the true nature of these fascicles of leaves, some of which lengthen out into branches during the 
summer. Indeed, the fruit-cones occasionally lengthen out in this way into leaf-bearing branches, illustrating the homology subsisting between the bract-scales of the cone and the scale-leaves of the branch.

The leaves of many species of Pine persist several years. The Larch is deciduous.

The Pine Family acquires high importance from the number of species which it includes affording valuable timber, and also from tho resinous products obtained from several of them. Among those most valued for the sake of their limber are:- - .

Scotch Fir, affording Yellow Deal-the only Pine now native in Britain; Norway Spruce (Abies excelsa), yielding White Deal, formerly a British tree, as its cones are found in very recent geological formations;'Weymouth Pine (Pinus Strobus), the most valuable timber fir of North America; Douglas Pine (Abies Douglasii), of which a spar 159 feet in length is erected as a flag-staff in the pleasure-grounds at Kew ; Larch, largely used for railway sleepers; the New Zealand "Cowdi" Pine (Dammara), affording mast spars 200 feet long. The wood of Cypress (Cupressus sempervirens) is almost imperishable; the gates of Cunstantinople made of this wood lasted 1,100 years. The wood of Juniperus virginiana is commonly used for "lead pencils," under the name of Red Cedar. That of the true Cedar (Cedrus Libani) is comparatively worthless. The wood of the Yew is said never to be attacked by insects. Bows were formerly made of it in Britain, and by an Act of Edward IV. every Englishman was obliged to possess a 
bow of his own length, made either of this wood or of Wych-Hazel, Ash, or Auburn (? Laburnum $)$. Yew attains a very great age, some English trees being estimated at about 2,000 years.

Wellingtonia gigantea of California is the mammoth amongst trees; one specimen has been described $450 \mathrm{ft}$. high, and $116 \mathrm{ft}$. in circumference.

Of resinous products, the most important are Tar and Turpentine. Tar is distilled from faggots of Pine, chiefly Scotch Fir, in the North of Europe. The residuum left after the distillation of the liquid part from Tar is Pitch. Turpentine is afforded by several species of Pine, especially Pinus palustris, an American species, and, during the late American war, by $P$. Pinaster of the South of France. The Turpentine exudes from wounds made in the trunk near the ground. Common Resin or Rosin is the residuum after distillation of Oil of Turpentine. The Cowdi or Kauri resin of New Zealand, used in making varnishes, is exuded by the Cowdi Pine. The largest masses of it are said to be found buried in the soil far from places where the tree now grows.

The seeds of a few species are edible, those of the Stone Pine ( $P$. Pinea) being brought to market in the South of Europe, strung together like beads on a string. The large seeds of the Bunya-bunya Pine (Araucaria Bidwilli) are eaten by the aborigines of East Australia. Juniper berries are used to flavour gin. 


\section{CLASS II.-MoNoCOTYLEDONS.}

Sub-class. Spadicifloræ.

62. Natural Order-Aroideæ. The Arum Family.

Distribution. - A large Family, most numerous in tropical and sub-tropical countries.-British genera 2, species 2.

Herbs. Flowers upon a spadix.

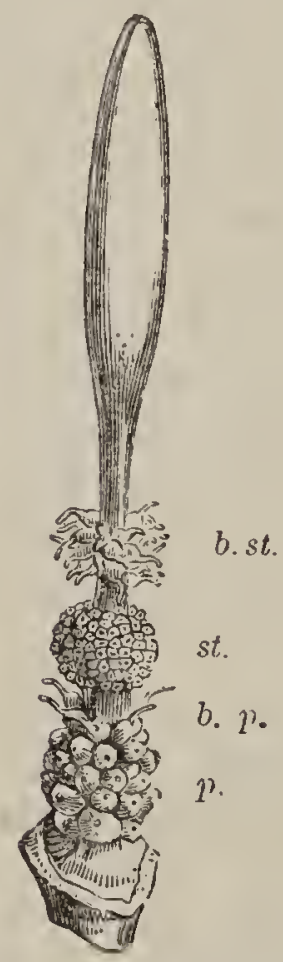

Frg. 167. Spadix of Arum, st. stamens; b.st. rudimentary stamens ; $p$. pistils; b.p. barren pistils.

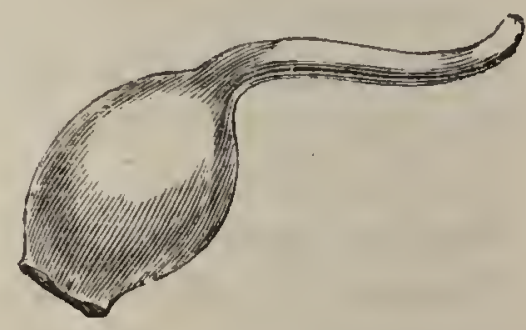

Fig. Ifs. Barren pistillate flower of same.

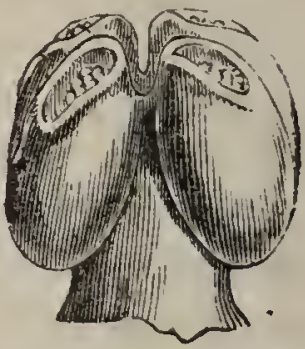

Fra. 169. Single stamen of same, constituting a naked, monandrous flower.

Type-Common Arum (Arum maculatum).

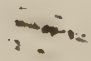


Herb, with tuberous stock (corm), radical sagittate leaves, and numerous unisexual achlamydeous flowers upon a succulent spike (spadix), sheathed by a large membranous bract (spathe).

\begin{tabular}{|c|c|c|c|}
\hline Organ. & No. & Cohesion. & Adhesion. \\
\hline \&, Stamens. & 1 & Monandrous. & 0 \\
\hline $\begin{array}{l}\text { \&, Pistil. } \\
\text { carpels. }\end{array}$ & 1 & Apocarpous. & 0 \\
\hline
\end{tabular}

In Marsh Calla (Calla palustris), a common plant in the North of Europe, the flowers are

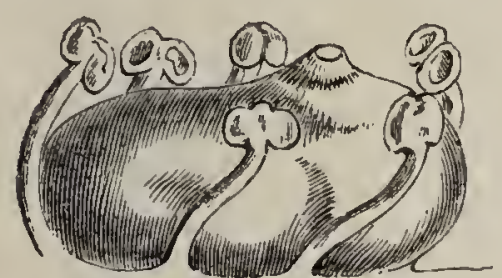

Fig. 170 Flower of Marsh Calla.

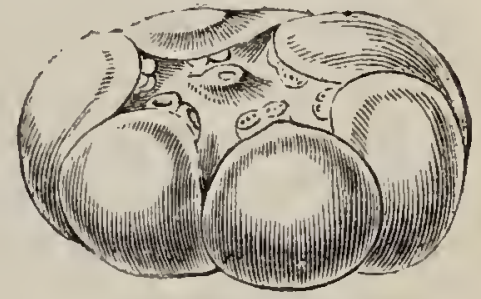

FIG. 171. Flower of Oronticm.

perfect, each consisting of a pistil surrounded by about 6 stamens. In Orontium the pistil and stamens are enclosed by a six-leaved perianth.

OBSERVE the extremely short and thick rhizome of Arum, distinguished as a corm, containing much starch, formerly collected in the Isle of Portland as "British arrowroot," and sold at Weymouth at eightpence per pound: the leaves, net-veined as in Dicotyledons.

The large tubers of Colocasia antiquorum are cultivated in tropical countries, and eaten like Yams; they all contain, as does Amem, an acrid juice, which is removed in cooking. 
Calla (Richardia) Ethiopica, a South Afriean plant, resembling the European Marsh Calla on a large scale, with a beautiful white, funnel-like spathe, is very commonly grown in parlourvindows.

63. Natural Order-Lemnaceæ. The Duckweed Family.

Distribution.-Waters of the northern hemisphere, rare between the Tropics.-One British genus, species 5 .

Type-Lesser Duckweed (Lemna minor).

A floating plant, consisting of minute green fronds bearing flowers in fissures of their margins.

The flowers are of extreme simplicity, consisting of a small membranous spathe, enclosing 2 stamens and a single carpel. Some regard each stamen as representing a distinct male, and the carpel a female flower.

Five species are native, one of which (L. polysrhiza) has been very rarely (? but once) observed in flower in Britain. Fra. 172. Inflorescence The flowers of the common

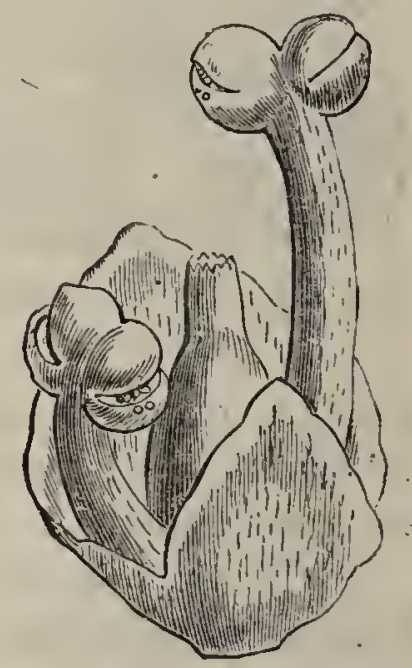
species are frequently overlooked, from "their minuteness.

Examine, with a lens, the tips of the slender roots of any Duckweed. They are covered by a highly developed modification of the cellular sheath, described at page 2 . 
64. Naturul Order-Naiadea. The Naiad Family.

Distribution.-Cusmopolitan aquatics, occurring both in fresh and salt water. - British genera 5 , species 14 .

Floating or submerged plants. Perianth 0 or 4-leaved. Pistil apocarpous.

-Type-Broad Pondweèd (Potamogeton ratans). An aquatic herb, with floating oblong or elliptical opaque petiolate stipulate leaves, and dense pedunculate spikes of minute flowers.

\begin{tabular}{|l||r|l|l|}
\hline \multicolumn{1}{|c|}{ Organ. } & No. & \multicolumn{1}{c|}{ Cohesion. } & \multicolumn{1}{|c|}{ Adhesion. } \\
\hline $\begin{array}{l}\text { Perianth. } \\
\text { leaves. }\end{array}$ & Polyphyllous. & Inferior. \\
\hline \begin{tabular}{l} 
Stamens. \\
\hline $\begin{array}{l}\text { Pistil. } \\
\text { carpels. }\end{array}$
\end{tabular} & -4 & $\begin{array}{l}\text { Tetrandrous. } \\
\text { Apocarpous. }\end{array}$ & Hypogynous. \\
\hline Seeds. & Solitary in each achene, exalbuminous. \\
\hline
\end{tabular}

OBSERve the sheathing axillary stipules of Pondweed: the tubular pollen-grains, destitute of an outer coat (extine), of Zostera, a plant with narrow, ribbon-like leaves, growing in the sea near low-water mark : the exalbuminous seeds of the Family.

It is remarkable that most of the Orders of Monocotyledons of aquatic habit are destitute of albumen in their seeds.

Allied to the Pondweeds is the rare Latticeleaf (Ouvirandra fenestralis) of Madayascar, the cellular tissue of the leaves of which is so reduced, that open spaces occur between the 


\section{veins, which form a delicate network resembling a "skeleton-leaf."}

From the extreme importance to mankind, the number of species, and majestic aspect of the Palms, a short notice of the Order to which they belong (Palmacex) is needful here, although none occur in Britain, and but a single species, the Dwarf Fan Palm (Chamcerops humilis). is native in Europe.

Palms are perennial Monocotyledons, either arborescent, rising sometimes to a height of 100 or 200 feet, or acaulescent (having no apparent stem), with a short or prostrate rhizome. The stem is rarely branched, growing only by its terminal bud. A cross-section of the stem is well adapted to show the irregular arrangement of the isolated vascular bundles characteristic of Monocotyledons. The leaves form an immense crown, terminating the stem, and arc often, singly, many feet in length. They are usually either of the radiate- or penni-veined type, though some are intermediate between the two forms. The flowers are arrangerl upon a spadix, sometimes many feet in length, enclosed, at least at first, in a large spathe, similar to that of Arums, though often hard and woody. The flowers are small and sessile upon the branches of the spadix, consisting of a 6 -leaved, or 6-lobed, perianth, usually 6 stamens, and a tricarpellary pistil. Many of the species are diøcious or polygamous. The fruit is very variable both in structure and size. Compare, for example, that of the Cocon-nut Palm, the Date Palm, and Vegetable Ivory Palm. The secd is albuminous, and often solitary in the fruit when it is 1-celled by abortion.

As in other Monocotyledons, no tap-root is produced when the seed germinates; so that, in order to secure stability to the tall-growing stem, the crtyledon (one extremity of which remains in the seed to absorb the relatively abundant albumen) sometimes lengthens down. wards in to the soil to a considerable depth.

Amongst the more important species are :-

The Date Palm (Phoenix dactylifera), invaluable to the desert tribes of Northern Africa, serving as the staple food both of themselves and of their cattle. The pericarn is Heshy and sweet. The minute embryo may be found, ou 
scraping the back or side of the seed with a knite, near the middle, embedded in a cavity in the horny albumen.

Cocoa-nut Palm (Cocos nucifera). The large seed is contained within a thick pericarp, the outer layers of which are fibrous, affording "coir fibre," used for mats, brushes, and the like. The inner layer of the perical'l (endocarp) is hard and bony, forming the shell, which the natives of tropical shores, where the Cocoa Palm grows, carve into various utensils and ormanents. The coat (testa) of the secd is very thin and not separable from the inner surface of the endocarp, unless the nut be dried near a fire for a few days, when the secd may be taken out entire. A crack may be carried round the shell in any direction by turning the nut in the left hand and applying smart blows with a hanmer, two or three times all round, in the direction in which it is required to split. The minute cmbryo is concealed in a cavity immediately bencath one of the three "pores" near to the bottom of the shell. An oil uscd in candle- and soapmaking is obtained from the seed by pressure : 432,425 hundredweights of it werc imported in 1872. The juice which flows from wounds in the spadix of this and some other Palms is collected, fermented, and used as a beve. ruge callcd arrack or toddy.

Coquilla nuts and Piaçaba fibre are afforded by a Sonth American Palm, Attalea funifera. The endocarp $\therefore$ is the part used by turners to make toys and trinkets. lt is very hard and takes a high polish. A fibre, rescmbling whale-bone, separates from the margins of old leaves.

Vegetable Ivory is the hard albumen of the seeds of Phytelephas macrocarpa.

The Oil Palm (Elciis Guineensis) of West Africa aftords Palmi-oil, used in the manufacture of soap and candles. 'The oil is olstained from the fruits. 1,031,135 hundredweights of the oil were imported in 1871.

Sago is ohtained from the farinaceous cellular tissue of the trunk of species of Sagus, growing in the East Indian Islands.

Palm-sugar is prepareu from the juice of Phoenix and Eorassus, in India.

Rattan canes are the long flexible stems of Indian specics of Calamus, which resemble cordage stretched among the trees of their native Indian forests. 


\section{Sub-class. Petaloideæ.}

65. Natural Order-Alismaceæ. The Alisma Family.

Distribution.-A small but cosmopolitan aquatic Order. British genera 6, species 9. Perianth of 6 leaves. Pistil apocarpous. Ovary superior. Type-Common Alisma (Alisma Plantago). (Water Plantain).

An erect aquatic peremial herb, with radical petiolate leaves, and unequal whorled peduncles forming a loose pyramidal panicle.

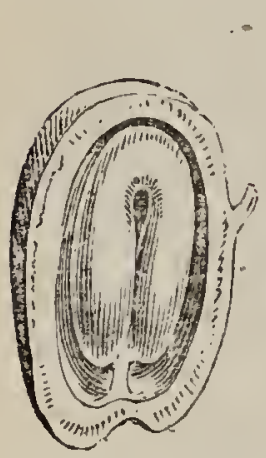

I. IG. 174. Longitudiual section of achene of same.

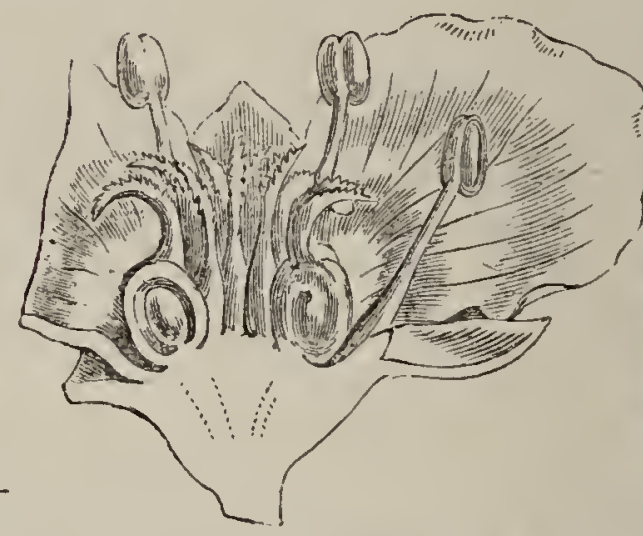

FIG. 173. Verucal section of flower of Common Alisma.

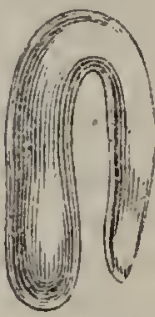

[ilc. 175. Embryu of sâme removed from the seed.

\begin{tabular}{|l||c|l|l|}
\hline \multicolumn{1}{|c|}{ Organ. } & No. & \multicolumn{1}{c|}{ Cohesion. } & Adhesion. \\
\hline $\begin{array}{l}\text { Perianth. } \\
\text { leaves. }\end{array}$ & 6 & Polyphyllous. & Inferior. \\
\hline $\begin{array}{l}\text { Stamens. } \\
\text { Pistil. } \\
\text { carpels. }\end{array}$ & $-\frac{6}{6}$ & Hexandrous. & Hypogynous. \\
\hline Seeds. & Exalbuminous, one in each carpel. \\
\hline
\end{tabular}

Obsfnve the difference between the submerged leaves, reduced to linear petio!es, and those which 
rise above the water in Common Alisma: the sepaloid outer and petaloid imner perianth-leaves of Alisma: the stamens in three series $(9$ altogether) in Flowering Rush (Butomus), and the anomalous placentation f the same species; the numerous ovules not being confined to the ventral sutures of the carpels, but scattered @ver the entire walls. Arrow he a d (Sagittaria) differs from Alisma in having the Alower's unisexual and monoecious.

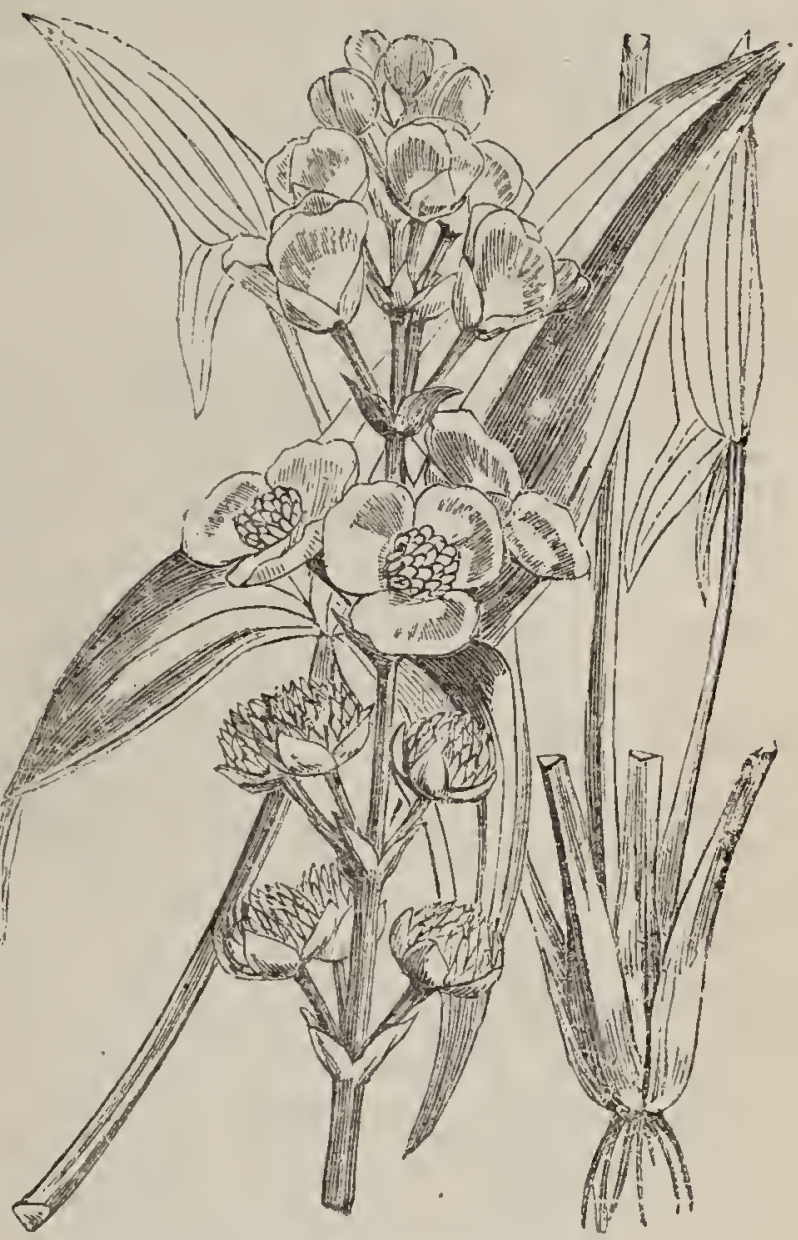

Fıa. 176. Sagittaria sagittofolia.

66. Nalural Order-Hydrocharideæ. The Hydrocharis Family.

Distribution. - Another small cosmopolitan aquatic order.-British genera 3, species 3.

Floating or submerged plants. Flowers unisexual. Ovary syncarpous, inferior.

Type-Common Frogbit (IIydrocharis Morsus-rance). Floating herb, with petiolate orbicular leaves, and diœcious pedicellate fiowers. 


\begin{tabular}{|c|c|c|c|}
\hline Organ. & No. & Cohesion. & Adhesion. \\
\hline $\begin{array}{l}\text { Perianth. } \\
\text { leaves. }\end{array}$ & 6 & Gamophyllous. & Superior. \\
\hline ¿ ,Stamens. & $|3-12|$ & Tri-dodecandrous & Hypogynous. \\
\hline $\begin{array}{l}\text { q, Pistil. } \\
\text { carpels. }\end{array}$ & 6 & Syncarpous. & Inferior. \\
\hline Seeds. & Sevc & al, exalbumino & \\
\hline
\end{tabular}

OBserve the leaf-buds, about the size of small peas, formed by the plant in autumn. These develop separate plants in the following spring. Two or three buds thrown into a pond have speedily covered it with Frog-bit.

The "New Water-weed" (Elodea canadensis), an American plant, was first remarked in Britain in 1817. It has since become distributed with marvellous rapidity in the rivers, canals, and ponds of the midland counties. As pistillate flowers only are found, no seeds can be perfected, so that the multiplication is solely by the breaking up of the plant into fragments, each fragment originating an independent plant.

A South European species (Vallisneria spiralis), with long narrow leaves, is commonly grown in fresh-water aquariums. The small pistillate flowers rise, upon a slender peduncle, to the surface of the water in which the plant grows, reaching a great length when the water is deep. The staminate flowers, on the other hand, are sessile near the root; and when their pollen is ripe, they break off from the plant and float to the surface, where they fertilize the stigmas. The leaves are well adapted for showing the "rotation" of the cell-sap under the microscope. 
67. Natural Order-Liliaceæ. The Lily Family.

Distribution,-A large Order, numerously represented in each quarter of the globe.-British genera 17 , species 30 .

Herbs (or a spinose shrub). Perianth-segments petaloid, stamens 6 (except Paris). Ovary superior.

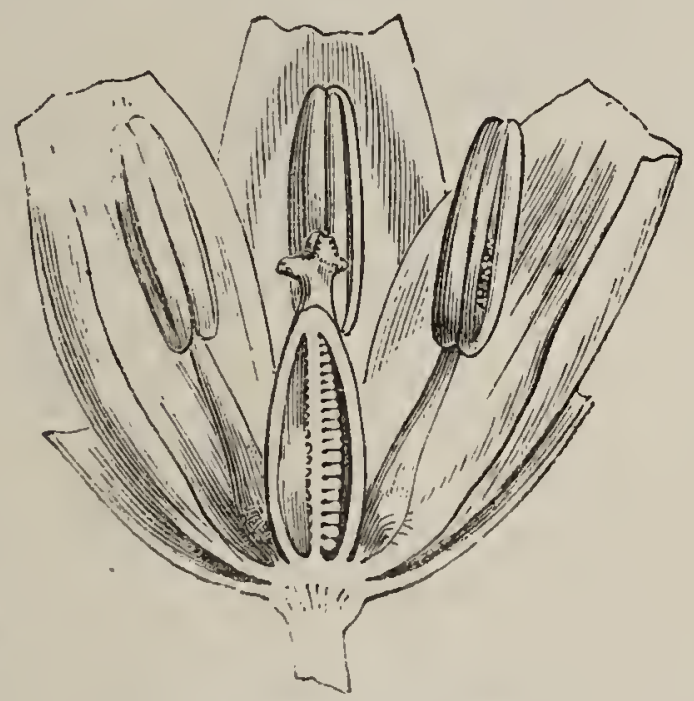

Fic. 177. Vertical section of flower of Wild Taip.

"Jy pe-Wild Tulip (Tulipa sylvestris).

A bulbous herb, with 1 to 3 narrow lanceo. late leaves, and a single terminal large yellow flower upon an erect scape.

\begin{tabular}{|c|c|c|c|}
\hline Organ. & No. & Cohesion. & Adhesion. \\
\hline $\begin{array}{l}\text { Perianth. } \\
\text { leaves. }\end{array}$ & 6 & Polyphyllous. & Inferior. \\
\hline Stamens. & 6 & Hexandrous. & Hyposynous. \\
\hline $\begin{array}{l}\text { Pistil. } \\
\text { carpels. }\end{array}$ & 3 & Syncaryous. & Superior. \\
\hline Seeds. & \multicolumn{3}{|c|}{ Indefinite, albuminous. } \\
\hline
\end{tabular}


This Order is a very large one, including many' species, which deviate nore or less from: the above Type. As Sub-types, represented in Britain, observe :

1. Butcher's Broom (Ruscus aculeatus), (the only British monocotyledonous shrub,) bearing diøecious flowers upon flat spinose branches; which would be taken for leaves were they not axillary productions, springing from the axils of minute scales, which represent the true leaves. A young shoot is required to show the true scalelike leaves, as they wither very soon. Compare, with the leaves of Butcher's Broom, the scalelike leaves of Asparagus, bearing a fascicle of slender acicular branchlets (cladodia) in their axils. This plant grows wild upon some parts of the British coast.

2. Herb Paris (Paris quadrifolia), anomalous amongst Monocotyledons from the tetramerous symmetry (parts in fours) of the flowers. The perianth is, normally, double, with 4 leaves in each whorl, 8 stamens, and 4 carpels. The parts of the perianth vary, however, from 3 to 6 .

OBSERve the structure of the buib, exhibited in a cross-section of Hyacinth or Onion, and of White Lily; in the two former the scales are broadly overlapping (tunicate bulbs), in the last-named they scarcely overlap : the bulbels in the axils of the leaves of Lilium bulbiferum, common in gardens; these are capable of independent growth, and, falling off, serve to propagate the plant. In some species of Garlic (Allium) several of the arrested flower-buds become bulbels, which develop young plants in a similar way.

Many of the Liliacex are highly ornamental 
and much prized as garden flowers. Ciulips, the numerous species of Lily, Hyacinths, the Crown

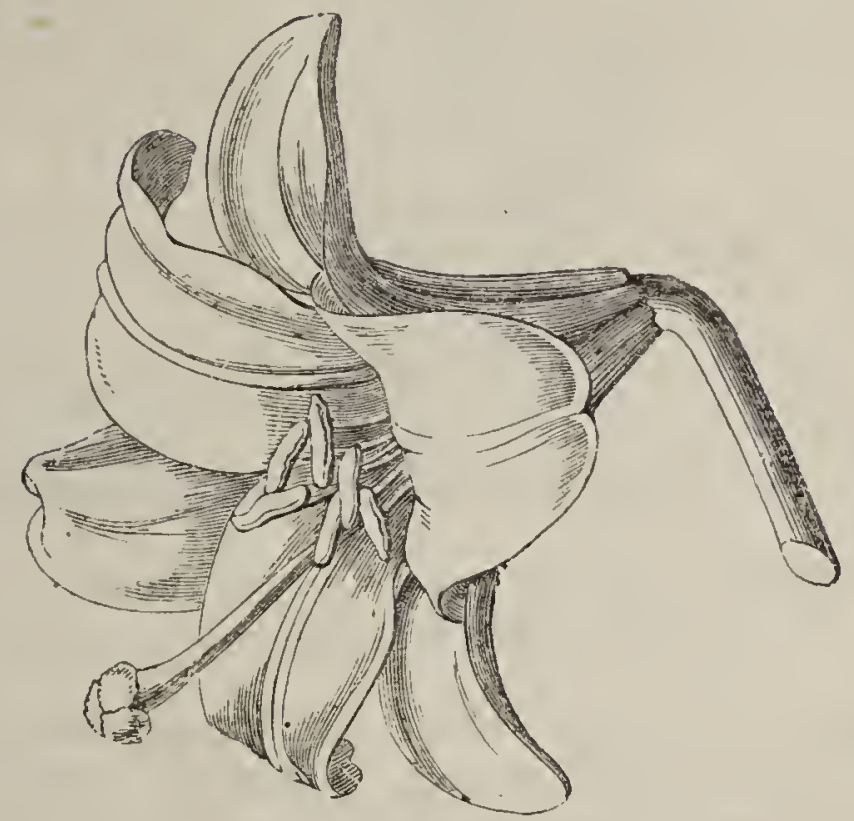

FIa. 178. Flower of White Lily.

Imperial, Asphodels, and Yucca or Adam's Needle, belong to the Order.

Several useful products are derived from the Lily Family, including the drug Aloes, which is the dried juice obtained from the leaves of species of Aloe growing in Africa and the West Indies, and New Zealand Flax, a strong fibre, affurded by the leaves of Phormium tenax, used for cordage, \&c.

68. Natural Order-Juncaceæ. The Rush Family.

Distribution:-A small, widely-diffused cosmopolitan Order, a considerable proportion affecting cool or alpine localities.-British genera 2 . species 20. 


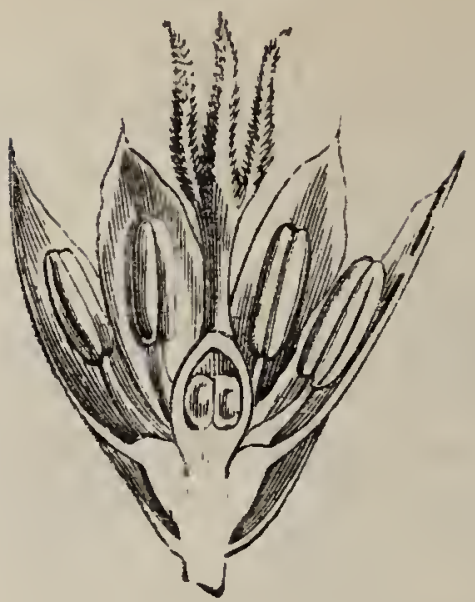

Fir. 179. Vertical section of flower of Field Woodrish.

Herbs. Perianth-leaves scarious, stamens 6. Ovary superior.

Type-Field Woodrush (Luzula campestris).

An herb, with tufted grass like leaves, and slender erect stems, bearing close heads of small, dry flowers.

\begin{tabular}{|l||c|l|l|}
\hline \multicolumn{1}{|c|}{ Organ. } & No. & \multicolumn{1}{c|}{ Cohesion. } & \multicolumn{1}{|c|}{ Adhesion. } \\
\hline $\begin{array}{l}\text { Perianth. } \\
\text { leaves. }\end{array}$ & $\frac{6}{\text { Polyphyllous. }}$ & Inferior. \\
\hline $\begin{array}{l}\text { Stamens. } \\
\text { Pistil. } \\
\text { carpels. }\end{array}$ & 3 & Hexandrous. & Hypogynous. \\
\hline Seeds. & Threarpous. & Superior. \\
\hline
\end{tabular}

Observe the scarious perianth and extremely minute embryo, by which the Order is distin. guished from Liliacer. In general aspect the species of the Rush Faniily resemble Sedges, but differ from them in possessing a complete sixleaved perianth. 
The wick of "Rushlights" is the cellular pith. like tissue of peeled stems of Rush (Juncus effusus). Under the microscope this pith-like tissue exhibits beautifully star-shaped (stellate) cells.

69. Natural Order-Orchidaceæ. The Orchid Family.

Distribution.- Widely diffused through both hemispheres; especially numerous in humid and warm regions. A large portion of tropical spncies are epiphytal.-British genera 16 , species 37 .

Herbs. Perianth irregular. Stamen 1 (except Cypri. pedium), anther gynandrous. Ovary inferior.

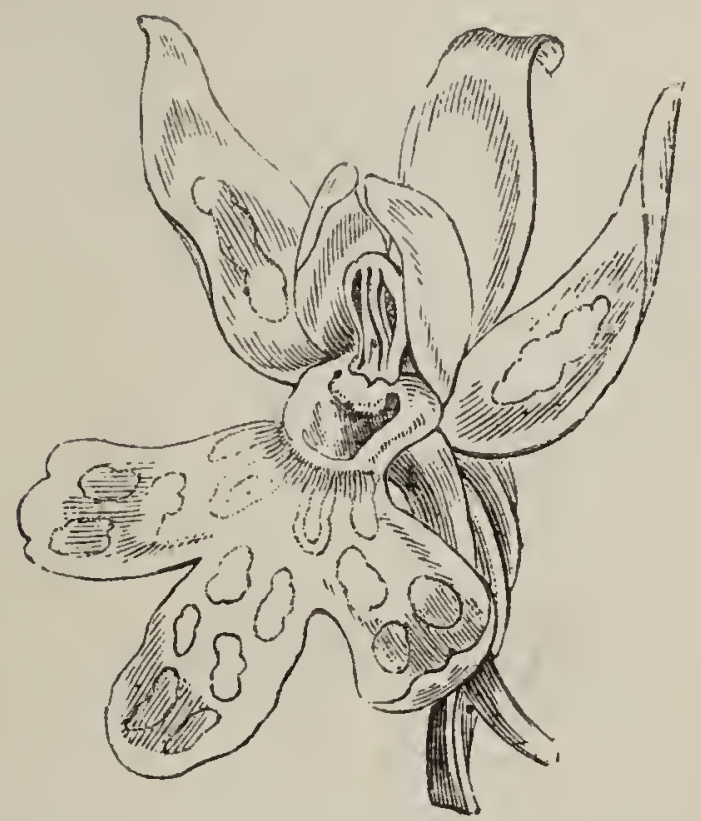

Fis. 180. Flower of Spotted Orchis.

Type-Spotted Orchis (Orchis maculata). A succulent herb, with a lobed tuberous root, 
erect leafy stem, and densely spicate pale pink or white irregular flowers.

\begin{tabular}{|c|c|c|c|}
\hline organ. & No. & Cohesion. & Allhesion. \\
\hline $\begin{array}{l}\text { Perianth. } \\
\text { leaves. }\end{array}$ & 6 & Gainophyllous. & Superior. \\
\hline Stamens. & 1 & Monandrous. & Gynandrous. \\
\hline $\begin{array}{l}\text { Pistil. } \\
\text { carpels. }\end{array}$ & 3 & Syncarpous. & Inferiol: \\
\hline Seeds. & \multicolumn{3}{|c|}{ Inuefinite, vers ıninute, exalbuminous. } \\
\hline
\end{tabular}

OBSERve the partial twisting of the ovary, which renders those parts of the flower which are really posterior apparently anterior: the enlarged 3-lobed lip (labellum), the base of which is continued into

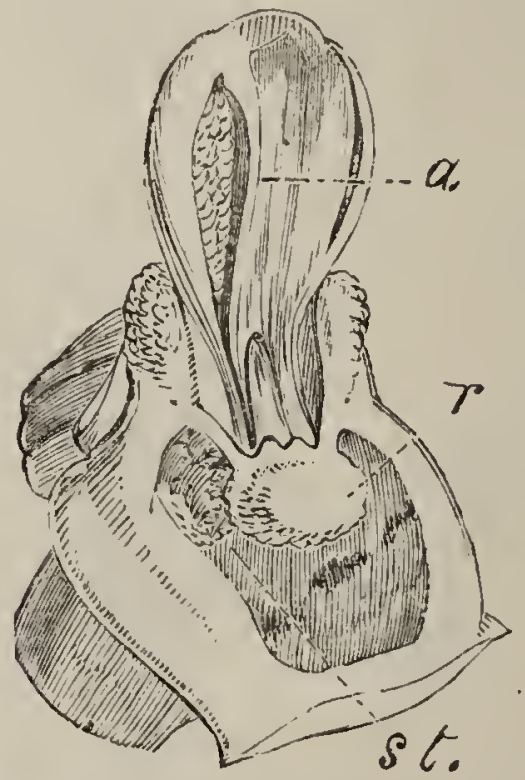

Fra. 181. Column of Spotted Orchis. $a$ anther ; $r$ rostellum ; $t$ stigma.

a spur, containing a sweet fluid (nectar), sought after by insects; hence the name nectary applied 
by the older botanists to this and similar spurs: the single anther adherent to the pistil, consisting of two more or less parallel lobes, opening in front lengthwise at an early period, and terminating helow in a small round knob (the rostellum), which projects over the mouth of the nectary immediately above the viscid stigmatic surface. The adherent anther, together with the rostellum and stigma, constitute the column of the Orchis flower.

Each anther-lobe contains a pollen-mass ( $p o l$ linium) -a mass of pollen-grains, held together

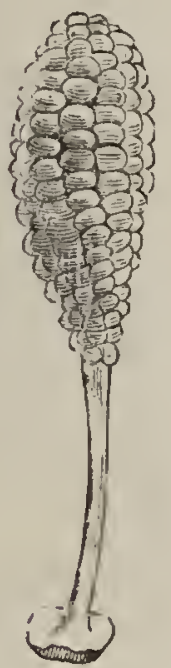

Fig. 182. Single jullen-mass of Spoucel Orchis, with its caudicle and gland.

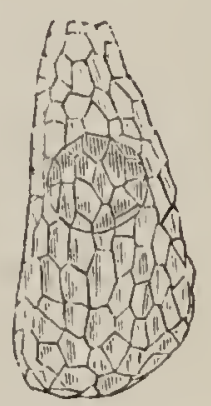

Fı. 183. Seed of same.

by internal elastic threads, which tie the pollen to a slender stalk, the caudicle. The caudicle terminates in a minute viscid ball, called the gland, embedded in the rostellum.

Take the very fine stem of a grass, or a finelypointed pencil, and thrust it gently into the spur of a newly-expanded flower, which has not lost its pollen, just as an insect would insert its pro- 
boscis when in search of nectar. It will be found that the pencil does nut fail. to push against the projecting rostellum, so that the pouch-like membrane of the latter is pressed down, and the pencil comes in contact with the under viscid surface of one or of both of the little glands of the two pollen-masses. On withdrawing the pencil, the pollinia are found adhering firmly to it, for the viscid substance which bathes the glands sets hard in a few seconds when exposed. If the pollinia be carefully watched immediately after they are withdrawn from the anther, they may be observed to become inclined forwards to such an extent, that if, after the lapse of a minute or two, the pencil be thrust into the nectary of a second flower, the pollinia which adhere to the pencil will strike against the viscid stigmatic surface of the flower, and at least a portion of the pollen-grains will arlhere to it and fertilize the ovules of the flower.

The viscidity of the stigma is sufficient to overcome the strength of the delicate threads which bind the grains of pollen together.

From the peculiar relative arrangement of the pollen-masses and stigma in Orchids, Mr. Darwin has shown that the flowers can be but very exceptionally self-fertilized. Almost invariably insect aid is required to transport the pollen from flower to flower: hence the importance of the contrivances indicated above (to which Mr..Darwin has recently directed attention), to insure the proper fulfilment of the important function assigned to unconscious agents.

Compare with Spotted Orchis the flowers of Pyramidal Orchis (O. pyramidalis) and Bee Orchis (Ophrys apifera). In Pyramidal Orchis, 
the two pollinia of each anther are united to a single saddle-shaped disk, so that they cau only be removed together. In the Bee Orchis, the caudicles are so weak, that when the anthercells open, the pollen-masses topple over in front and dangle opposite to the viscid stigma, the glands remaining in the rostellum. A puff of wind forces the suspended pollen-masses against the stigma, so that in this species self-fertilization appears usually to obtain.

Remarkable modifiations of these processes occur in exotic species. An Orchis should not be passed by in flower without experimenting upon its pollinia until the mode of its fertilization be understood.

The form of the labellum varies very much in different species, assuming sometimes grotesque shapes. The flowers of many tropical species are very beautiful and often singularly fantastic, so that they are favourites in hot-house cultivation, and are often sold at a very high price.

Many of the tropical species are called "airplants," from their being epiphytal - that is, growing upon the trunks of trees without becoming organically united to them as parasites. They cling to the bark by long greenish or white aerial roots, and absorb moisture partly from the air and partly from what trickles down the tree, charged with decaying organic and with inorganic matter. The lower internodes of the stem of these epiphytal Orchids often become swollen, forming what are called pseudo-bulbs.

One extremely rare British species, the Lady's Slipper (Cypripedizm Calceolus), represents a Subtype of the Order, differing from the Type in 
having 2 lateral anthers developed instead of the single posterior one, which is abortive in this genus.

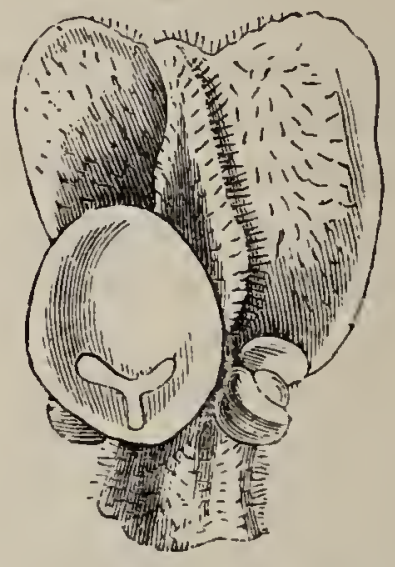

Fio. 1S4. Column of Lady's Slipper.

An American genus, Vanilla, affords a fragrant fruit, imported as Vanilla, and used in flavouring confectionery.

70. Natural Order-Iridex. The Iris Family.

Distribution.-Occurring in both hemispheres; most numerous in the Temperate Zones, and more especially at the Cape.-British genera 4, species 6 .

Herbs. Perianth-leaves 6. Stamens 3. Orary inferiar.

Type-German Iris (Iris Germanica).

A perennial herb with a thick shortly-creeping rhizome, distichous sword-shaped leaves, and showy blue hermaphrodite flowers.

(This garden species is selected as the Type, hecause tigured in Professor Henslow's Sheet liagrams.) 


\begin{tabular}{|l|r|l|l|}
\hline \multicolumn{1}{c|}{ Organ. } & No. & \multicolumn{1}{c|}{ Cohesion. } & \multicolumn{1}{|c|}{ Adhesion. } \\
\hline $\begin{array}{l}\text { Perianth. } \\
\text { leaves. }\end{array}$ & 6 & Gamophyllous. & Superior. \\
\hline $\begin{array}{l}\text { Stamens. } \\
\text { Pistil. }\end{array}$ & -3 & Triandrous. & Perigynous. \\
\hline $\begin{array}{l}\text { carpels. } \\
\text { Seeủs. Indefinite, albuminous, in a 3-celled capsule. }\end{array}$ \\
\hline
\end{tabular}

OBserve the equitant bases of the leaves, which are folded up the mid-rib and vertically flattened throughout, having the two sides of their upper surface coherent in the upper part of the leaf, . so that each exposed surface of the leaf answers really to one half of the lower surface. Observe, also, the stamens concealed under arching, petallike stigmas; the stigmatic surface is contined to a transverse line on the under surface of the latter.

Several handsome garden species belong to this Order, as well as the showy yellow Iris or Flag (I. Psendacorus). Anongst the rest Gladiolus and Crocus. From a species of Crocus (C. sativus), Saffron, formerly in great esteem as a drug, is obtained. It consists of the stigmas pressed into cakes and dried. This Crocus used to bo cultivated at Saffron Walden, in Essex, which place was chartered with arms, bearing three Saffron Crocuses, by Edward VI. An acre produced from $8 \mathrm{lbs}$. to $20 \mathrm{lbs}$. of Saffron. It is given to sick canaries, but its reputation has long been lost, and it is now chiefly used to colour other medicines. 
71. Natural Order-Amaryllidex. The Amaryllis Family.

Distribution.-Widely scattered through tropical and temperate countries of both hemispheres, numerous in the Mediterranean region and at the Cape of Good Hope.-British genera 3, species 4.

Herbs. Perianth-segments 6 . Stamens 6. Orarv inferior.

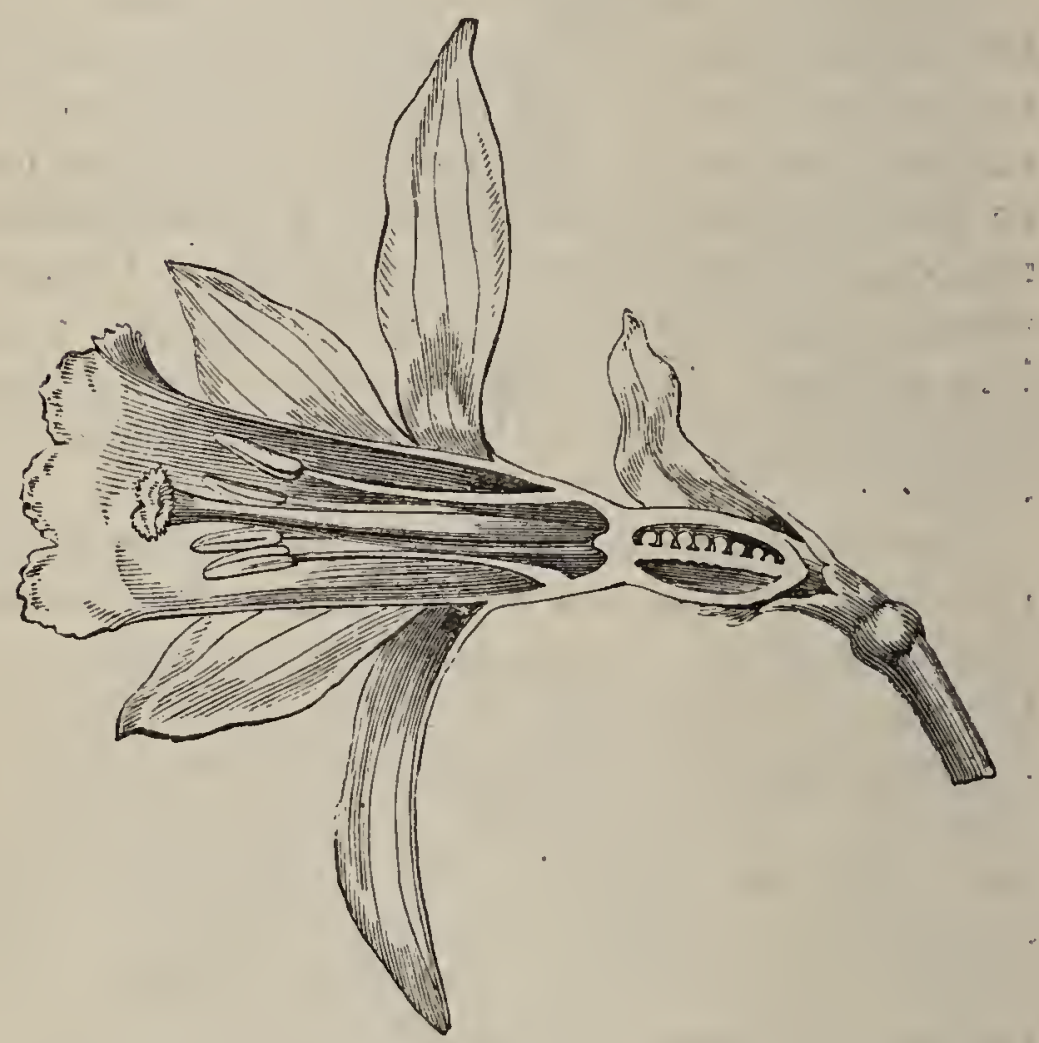

Fig. 185. Vertical section of flower of Daffodil Narcissus.

Type-Daffodil Narcissus (Narcissus Pseudonarcissusy.

A bulbous herb, with radical linear leaves, a membranous spathaceous bract, and showy soli- 
tary regular flower, borne upon an erect glabrous scape.

\begin{tabular}{l|r|l|l|}
\hline \multicolumn{1}{|c|}{ Organ. } & No. & \multicolumn{1}{c|}{ Cohesion. } & \multicolumn{1}{c|}{ Adhesion. } \\
\hline $\begin{array}{l}\text { Perianth. } \\
\text { leaves. }\end{array}$ & 6 & Gamophyllous. & Superior. \\
\hline \begin{tabular}{l} 
Stamens. \\
\hline $\begin{array}{l}\text { Pistil. } \\
\text { carpels. }\end{array}$
\end{tabular} & $\begin{array}{l}\text { Hexandrous. } \\
\text { Serigynous. }\end{array}$ & Syncarpous. & Inferior \\
\hline \begin{tabular}{l} 
Seeds. \\
\hline
\end{tabular}
\end{tabular}

OBSERve the corona referred to at page 50. It is very much shorter in other species, as in the white-flowered Poet's Narcissus ( $N$. poeticus) and Jonquil ( $N$. Jonquilla). It is wanting in Snowdrop (Galanthus).

Amaryllidaceæ much resemble Lilies, differing principally in their inferior ovary.

The bulbs of several species yield a poisonou.s juice, and the flowers of Daffodil are said to be very poisonous.

One of the most important exotic species is the so-called American Aloe (Agave Americana), which has become thoroughly naturalized in countries bordering upon the Mediterranean. From the Agave the Mexicans prepare an intoxicating beverage in common use, called "pulque."

72. Natural Order-Dioscoreaceæ. 'The Yam Family.

Distribution.-A small Order, chiefly confined to tropical and sub-tropical countries. One British genus, species 1 .

Type-Common Tamus (Tamus communis).

(Black Bryony.) 
A climbing herb, with alternate shining cordate leaves, small racemose unisexual flowers, and scarlet berries. (The only British species.)

\begin{tabular}{|c|c|c|c|}
\hline Organ. & No. & Conesion. & Adhesion. \\
\hline $\begin{array}{l}\text { Perianth. } \\
\text { lecues. }\end{array}$ & 6 & Gamophyllous. & Superior. \\
\hline$\delta$,Stamens. & 6 & Hexandrous. & Epiphyllous. \\
\hline $\begin{array}{l}\text { \%,Pistil. } \\
\text { carpels. }\end{array}$ & 3 & Syncarpous. & Inferior. \\
\hline Seeds. & \multicolumn{3}{|c|}{ Few, albuminous, in a berried fruit. } \\
\hline
\end{tabular}

N.B.-This species, although commonly-called Black Bryony, has nothing to do with the genus Bryonia, belonging to the Dicotyledonous Order Cucurbitaceæ (page 180). Common Tamus differs from most of the species of this Order in having a berried (baccate) instead of a calpsular fruit.

A few species, belonging to the exotic genus Dioscorea, produce large tubers, which, under the name of Yams, form an important article of food in tropical countries. The rhizome of a Cape species (T'estudinaria elephantipes), attaining an immense size, sometimes more than $3 \mathrm{ft}$. in thickness and height, is covered with a corky bark, and seems to endure for a very long period, throwing up annual stems, resembling those of the Black Bryony. From the appearance of the rhizome, it is called "Elephant's foot" at the Cape of Good Hope, where it was formerly eaten by the aborigines as "Hottentot Bread." 
Sup-Class. Glumifera.

73. Natural Order-Cyperacea. The Sodge Family.

Distribution.-A large Order, widely dispersed from the Arctic Zone to the Equator, in both hemispheres. A large proportion of the species affect moist situations.-British genera 9, species $74-80$.

Herbs. Sheaths of leaves not split. Flower in the axil of a single scaly bract (glume).

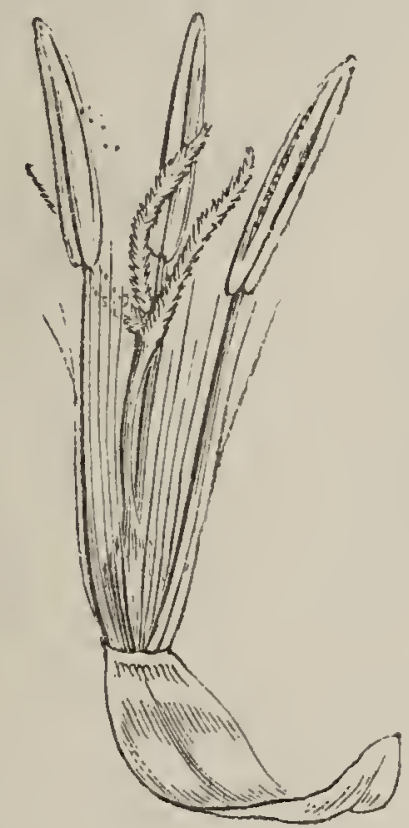

Fig. 186 Flower of Cotton Sedge.

Type-Common Cotton Sedge (Eriophorum polystachyum).

A grass-like herb, with an ereet stem, bearing several sessile and pedunculate spikes, with long white and cottony hypogynous bristles in fruit.

In this Order the ovary is 1-celled, but the divided style or stigma indicates the syncarpous character of the pistil. . 


\begin{tabular}{|l||c|l|l|}
\hline \multicolumn{1}{|c|}{ Organ. } & No. & \multicolumn{1}{c|}{ Cohesion. } & \multicolumn{1}{|c|}{ Adhesion. } \\
\hline Perianth. & & Numerous hypogynous bristles. \\
\hline Stamens. & 3 & Triandrous. & Hypogynous. \\
\hline $\begin{array}{l}\text { Pistil. } \\
\text { carpels. }\end{array}$ & 3 & Syncarpous. & Superior \\
\hline Seeds. Solitary, albuminous, in a l-eelled achene. \\
\hline
\end{tabular}

The largest genus of the Order is Carex, of which nearly 50 species are native in Britain, Carex differs from the type in having monœcious flowers, arranged in spikes: the male flowers.
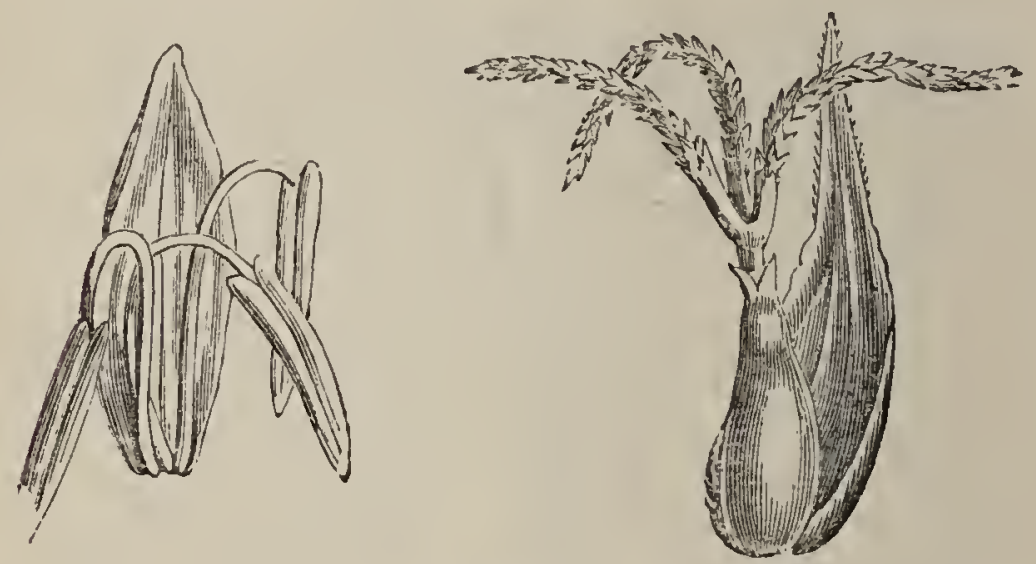

Fıc. 187. Male flower of Carex. Fig. 188. Fensale thower of sama

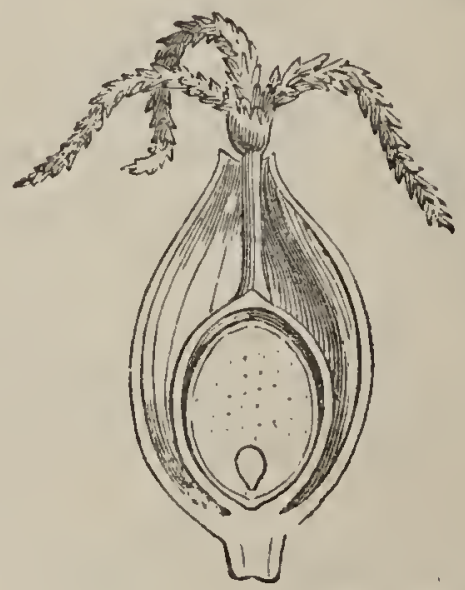

Fia. 189. Vertical section of fruit of same. 
consisting of 3 stamens, destitute of a perianth, borne in the axil of a scale-like bract, called a glume; the female flowers, each enclosed in a flask-shaped loose integument, called the perigymium, which is open at the apex, to allow the style and stigmas to protrude.

The Papyrus used as paper by the ancients, especially the Egyptians, was prepared from the pith-like tissue of the stem of a large Cyperus.

A common plant in the fens, Scirpris lacustris, is cut for chair-bottoms, baskets, mats, horsecollars, bottle-covers, \&c.

The cottony bristles of Cotton Sedge are collected for stuffing pillows. They are not of sufficient staple to be woven like cotton.

The Sand Carex (Carex arenaria), and a grass, the Sea Maram (Psamma arenaria), form long creeping rhizomes, which are highly important in binding the moving sands of dunes and embankments on the sea-coast.

74. Natural Order-Graminex. The Grass Family.

Distribution.- A very large and cosmonolitan Order. Some tropical genera (of Bambuser) are arborescent.-British genera 42, species 100.

Herbs. Sheaths of leaves split in front (except Common Melick). Flowers sheathed by two-rowed scaly bracts (glumes); innermost glume (pale) 2-nerved.

Iype-Common Wheat (Triticum vulgare). An annual, with an erect unbranched jointed stem $(\mathrm{culm})$, and distichous spicate flowers.

The structure of the flower of wheat is der scribed at page 53.

The table on the next lage will serve to 
show in what particulars several grasses, British and exotic, deviate from the above Type. (The first eight species are figured in Professor Henslow's Sheet Diagrams.)

The first column gives the name of the species. The second shows the kind of inflorescence, which is generally a panicle, though often compressed, or the branches so short, as to resemble a raceme

\begin{tabular}{|c|c|c|c|c|c|c|c|}
\hline & 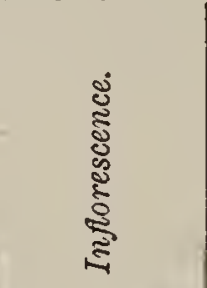 & 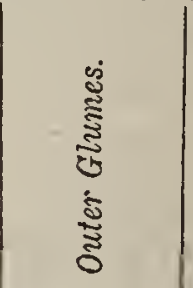 & 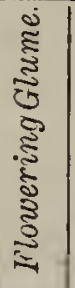 & $\widetilde{\Xi}$ & 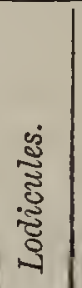 & 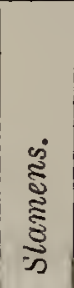 & 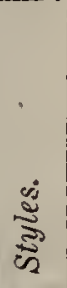 \\
\hline \multicolumn{8}{|c|}{$\begin{array}{l}\text { * Smpty glumes, or imperfect flowers of the spikelet, in- } \\
\text { gerted below and outside of the single perfect flower. }\end{array}$} \\
\hline $\left.\begin{array}{l}\text { Vernal Grass } \\
(\text { Anthoxanthum })\end{array}\right\} \mid$ & Spicate & 4 & 1 & 1 & $0 !$ & $2 !$ & 2 \\
\hline \multicolumn{8}{|c|}{$\begin{array}{l}\text { ** Enpty glumes, or imperfect flowers of the spikelet, when } \\
\text { present, inserted above the perfect flower or flowers. }\end{array}$} \\
\hline WHELT (Triticum) & $\begin{array}{l}\text { Spicate } \\
\text { (distichous) }\end{array}$ & 2 & 1 & 1 & 2 & 3 & 2 \\
\hline OAT (Avena) & Panicle & 2 & $\cdot 1$ & 1 & 2 & 3 & 2 \\
\hline BARLEY (Hordeum) & $\begin{array}{l}\text { Spicate } \\
\text { (distichous) }\end{array}$ & 2 & 1 & 1 & 2 & 3 & 2 \\
\hline $\begin{array}{l}\text { Feather grass } \\
\text { (Stipa) }\end{array}$ & Panicle & 2 & 1 & 1 & $3 !$ & 3 & 2 \\
\hline $\begin{array}{c}\text { Mat grass } \\
(\text { Narclus })\end{array}$ & Spike & $0 !$ & 1 & 1 & $0 !$ & 3 & $1 !$ \\
\hline RICE (Oryza) & Panicle & 2 (minute) & 1 & 1 & 2 & $6 !$ & 3 \\
\hline $\begin{array}{l}\text { MAIZE or INDIAN } \\
\text { CORN (Zea) }\end{array}$ & $\left.\delta \begin{array}{c}\text { Panicled } \\
\text { racemes }\end{array}\right\}$ & 2 & 1 & 1 & 2 & 3 & 0 \\
\hline RyE (Secale) & $\begin{array}{l}\text { 9 Spicate } \\
\text { Spicatc }\end{array}$ & $\begin{array}{l}2 \\
2\end{array}$ & $\begin{array}{l}1 \\
]\end{array}$ & $\begin{array}{l}1 \\
1\end{array}$ & $\begin{array}{l}0 \\
2\end{array}$ & $\begin{array}{l}0 \\
3\end{array}$ & 1! \\
\hline Rye grass(Lolizm) & Spicate & $1 !$ & 1 & 1 & 2 & 3 & 2 \\
\hline $\left.\begin{array}{l}\text { Fox tail } \\
\text { (Alopecurus) }\end{array}\right\}$ & Spicate & 2 & 1 & $0 !$ & $0 !$ & 3 & 2 \\
\hline
\end{tabular}

or spike, when it is termed racemose or spicate. The third column gives the number of outer 
glumes to each spikelet; the fourth indicates the presence or absence of the flowering glume; the fifth the presence or absence of the pale; sixth, the number of lodicules; seventh, of stamens; eighth, of styles.

The species printed in small capitals are Cornproducing or Cereal Grasses, called Cereals, from Ceres, the Roman goddess of Corn.

The sign ! denotes a striking deviation from the normal structure of Grasses.

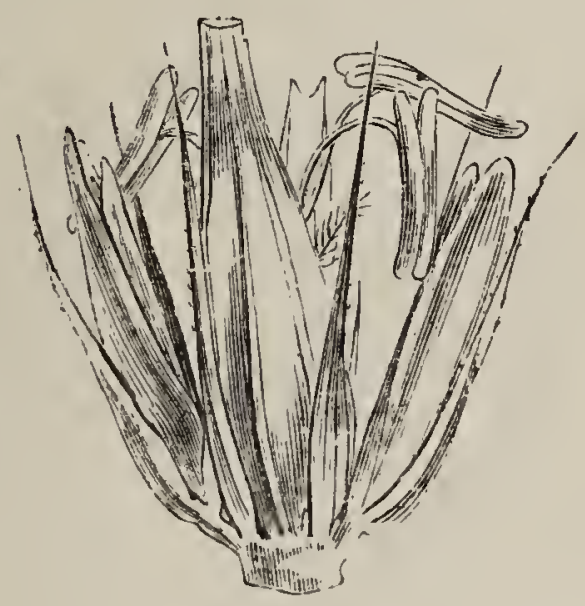

Fio. 190. Ternate 1-1lowered suikelets of Barley.

The arrangement of the flowers of Barley re quires explanation. The 1-flowered spikelets are arranged, three together, on - each joint of the axis (rachis) of the inflorescence. In two-rowed Barley, the single floret of the central spikelet only is fertile, the florets of the 2 lateral spikelets being barren; in six-rowed Barley, each of the 3 spikelets contains a fertile floret.

Compare Rye with Barley. They are very similar at first sight, but the spikelets in Fye, .nstead of being in threes, are arranged singly 
upon the rachis, as in Wheat, and each spikelet contains 2-lateral fertile florets and a central floret, represented by a minute rudiment or pedicel simply, which is easily overlooked.

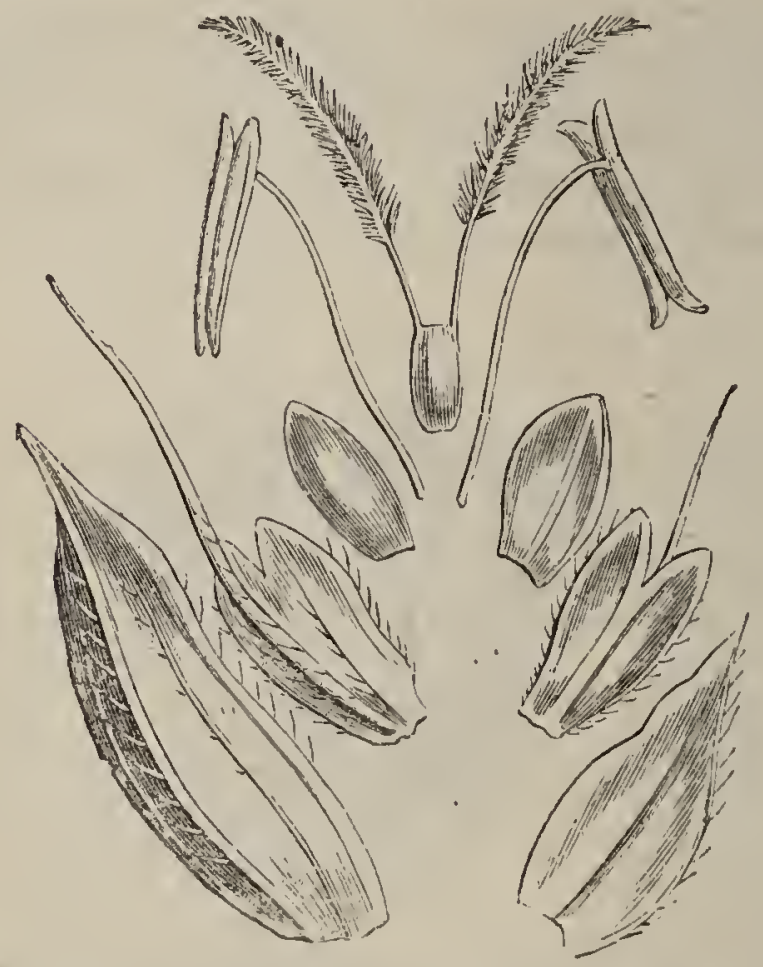

Fra. 191. Spikelet, dissected, of Vernal Grass. The lowest pair of scales, right and left, are the outer glumes; then come two awned empty glumes; then, to the right, the flowering glume, and, to the left, the small pale; lastly the two stamens and the pistil.

ObServe, in any common Grass, the stem, called a culm, usually hollow (fistular), jointed, and with sheathing leaves, the sheath being almost invariably split down the front, and embracing the culm: the ligule, a scale-like stipular projection at tho base of the blade of the leaf, where it passes into the sheath : the fruit, commonly, but incorrectly, called the seed, is termid, by botanists, a cary 
opsis. The thin pericarp is closely applied and adherent to the seed. In some Grasses, as in Barley and Oats, the pale, or the pale and flowering glume, adhere to the caryopsis, after the time of floweriug, and require to be removed from the grain by grinding. In Wheat and Rye, the caryopsis is free, not being adherent to the pale or Howering glume.

The Grass Family is unquestionably the most important in the Vegetable Kingdom to the human race, furnishing almost everywhere, and from the most remote antiquity, the principal basis of food. Rice alone affords a larger proportion of food to mankind than any other single species, while in cool climates Wheat, Rye, Barley, and Oats, and in warm countries Maize, Millet, and Durra (Sorghum), are universally grown.

Wheat (Triticum vulgare). Its native country is lost, as is the case with several plants which have been cultivated over a long period. This may be owing either to changes gradually introduced by cultivation, of such extent that the wild parent form is not recognisable, or to the original Type having become extinct.

Some botanists have tried to show that Wheat may have been derived from a South European grass, called AEgilops, forms intermediate between Wheat and one or two species of AEgilops having been occasionally met with. There can be no doibt, however, that these intermediates are hybrids, being usually barren, unless again crossed with one of the parent grasses; if with Wheat, they produce a grain closely resembling that of the latter.

Numerous varieties of Wheat are cultivated, 
with and without awns to the glumes and pales. The story of Wheat from the Egyptian catacombs having germinated appears to bave originated in a mistake.

Maccaroni and Vermicelli are prepared from the finest Wheat flour, chiefly in Italy.

Barley (Hordeum vulgare) is considered to have been the first Cereal brought under cultivation. It was grown in Palestine and Egypt, and is mentioned by Homer.

Malt is prepared by steeping Barley for about fifty hours, and then placing it, during nine to sixteen days, on a floor of slate or cement, until it germinates. It is then put in a kiln and heated to $160^{\circ}$ or $180^{\circ}$, then screened (thrown upon wire

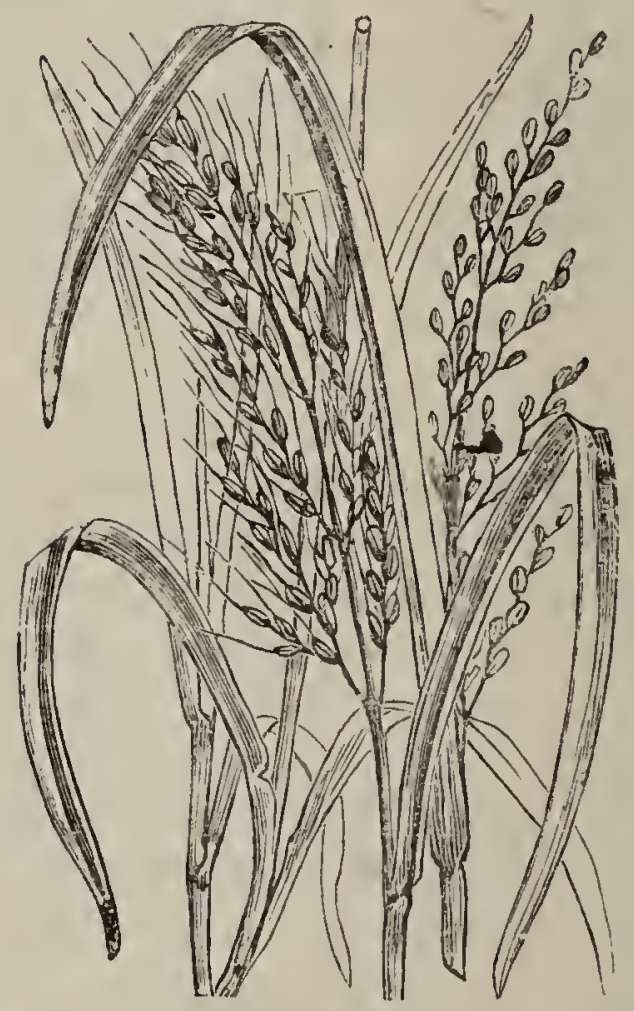

Fra. 192. Rice (Oryzu sultiva). Much roduced. 
sieves), so that the sprouted radicles (called coombs or chives) are broken off and separated. Germination converts the starch of the grains into a kind of sugar, which is capable of vinous fermentation, by which process alcoliol is formed. In brewing, the malt is steeped until the sugar is dissolved out, forming the "sweet wort." This is left to ferment, hops being added to impart a bitterness and preserving quality.

Oats (Avena sativa) appear to be of comparatively recent introduction, not having been eultivated by the Hebrews, Egyptians, Greeks, or Romans. They were grown, however, by the German races.

Rice (Oryza sativa) is grown in nearly all hot countries. We import it from India and the

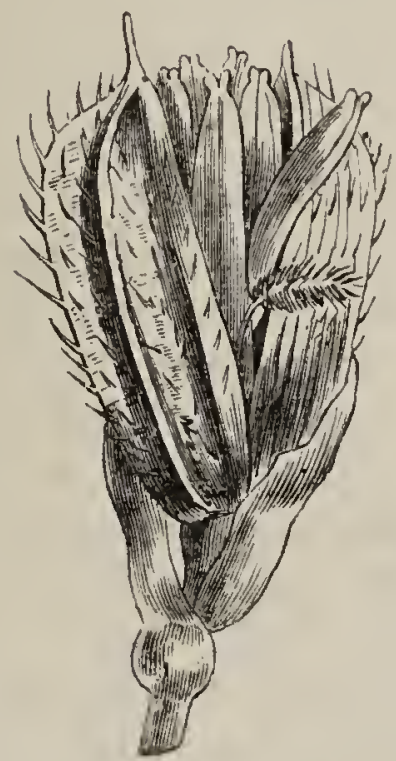

FIG. 103. One-flowered Spikelet of Rice.

Indian Islands, Southern United States, and South of Europe. Nearly 7,000,000 hundred- 
weights of Rice, with the husk removed, were imported into the United Kingdom in 1872.

Maize or Indian Corn (Zea Mä̈s) is a native of the New World, though now introduced into the warmer regions of this hemisphere, where it is cultivated to a great extent, especially in the Indian Islands and North Africa. It is the largest of the Cereals, and remarkable for its monocious flowers. A preparation of Indian Corn is sold under the name of "Oswego Corn."

Small grains, belonging to an unknown variety of Maize, have been found in ancient Peruvian tombs. They may have belonged to the original stock, which has since become improved by culture. Leaves of Maize are used for packing oranges.

The principal source of Sugar is the tall solid stem of a grass-the Sugar Cane (Saccharum officinarum)-cultivated widely in the Tropics. The canes are pressed between rollers to express the saccharine juice, which is boiled down, clarified, and crystallized. The uncrystallizable residue is drained off as Molasses or Treacle. The rind of the Sugar Cane, like that of most grasses, contains much silica, so that when it is burnt a glassy slag results, which renders the crushed Sugar Canes ill-adapted to serve as fuel. Upwards of 13,800,000 hundredweights of unrefined Sugar were imported in 1872 .

The stems (straw) of various Cereals, and of some wild grasses, are used for plaiting, being split by simple instruments into narrow strips. Straw is also worked up into a cheap, brittlo paper. 
Species of Bamboo (Bambusa) attain a great size ; one ( $B$. arundinacea) growing thirty feet in height in the Palm Stove of the Royal Gardens at Kew within about three months every year. The light, hollow, jointed stems of the Bamboo are applied to an infinite variety of purposes. 


\section{Flowerless or Cryptogamic Plants.}

Thus far I have avoided reference to those plants which are commonly regarded as flowerless, and which have long been classed together under the general term of Cryptogams, from the apparent absence of organs corresponding to the stamens and pistil of the plants which have hitherto occupied our attention.

I have passed these plants by because, from the considerable difference which obtains between their structure (both of the Reproductive and of the Nutritive organs) and that of Flowering Plants, they cannot be conveniently studied together. Any study, however, of the Vegetable Kingdom from which they are wholly excluded must be exceedingly incomplete; and now that facility in observing has been acquired, attention may be directed to these so-called lower plants, with a fair chance of comprehending the relation in which they stand to the Flowering Plants already familiar to us, and of mastering a few of the principal features of their leading Families.

The more logical course might seem to be to study first these simple forms, and progress. from them to the more complicated, to which latter we have hitherto confined our attention; but from the excessive minuteness of their essential organs, and our imperfect acquaintance with many details of their structure and function, it is practically the best plan to leav' them to tho last, in 
a course of Elementary Botany like the present. space compels me to be brief in describing Cryptogams; and those who desire to extend their acquaintance with them I must refer to $\mathrm{Mr}$. Berkeley's excellent "Introduction to Cryptogamic Botany."

All the plants which I have described in foregoing chapters produce seeds containing an embryo, provided (with unimportant exceptions) with one or more rudimentary leaves, which we have termed Cotyledons. The plants which we have now to consider do not produce a seed containing an embryo, but are multiplied by minute reproductive bodies, called spores.

The spores consist usually of a simple cell. As they are destitute of an embryo, there cannot, of course, be any distinction of radicle, plumule, and cotyledons: in colssequence of the absence of the latter, Flowerless Ilants are tèrmed $\mathrm{Aco}$ tyledons.

Although we speak of these plants as flowerless, it must be borne in mind that they do possess organs analogous to those which are essential to the flower, but they are so disguised; and often so simple, that they have been in many cases but recently recognised as such.

The more important Families of Acotyledons (Cryptogams or Flowerless Plants) are :

Possessing distinct stem and
leaves. $\left\{\begin{array}{l}\text { Ferns (Filices). } \\ \text { Club-mosses (Lycopodiacens). } \\ \text { Horsetails (Equisctacer }) . \\ \text { Mosses (Musci). }\end{array}\right.$

No distinction between stem (Mushrooms and Noulds (Fungi) and leaf. 
1. Natural Order-Filices. The Fern Family. Type-Male Shield Fern (Aspidium Filix-mas).

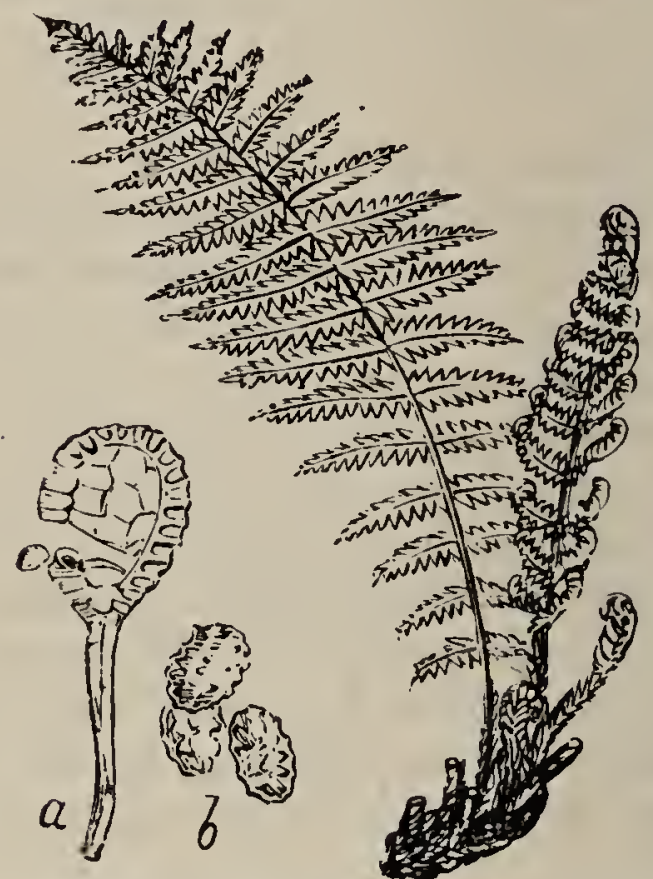

Fig. 194. Young and expanded fronds of Male Shield Fern. $a$ sporange $: b$ spores magnified.

A perennial herb, with a short thick rhizome, bearing a terminal tuft of large broadly lanceolate bipinnatifid annual fronds 2 to 4 feet in length. The young, unfolding fronds are curled upon themselves like a crosier: hence the term circinate applied to the characteristic vernation of ferns.

Upon the under surface of the fertile fronds, the fructification is arranged in small, round clusters, brown when ripe. These clusters are termed sori (each cluster a sorus), and there are two rows of the sori upon, at least, the lower lobes (pinnules) of each of the pinnoe of the 


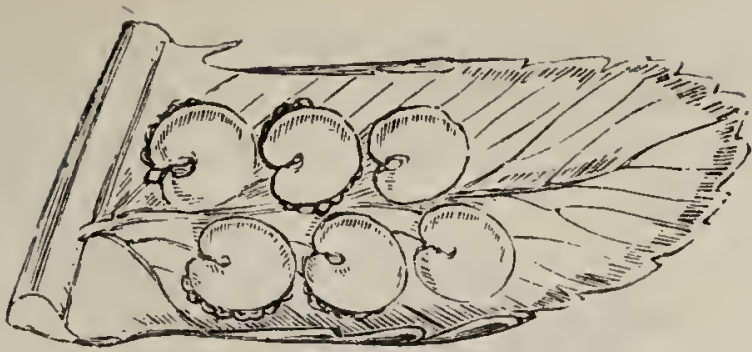

Fro. 195. Pinnule of Male Shield Fern, with six sori.

frond. These sori are protected at first by a reniform, pale-coloured membrane (indusium), which at length withers up, exposing the minute stalked sporanges of which each sorus is composed.

The sporanges require examination with a mag. nifying glass. They will be found to be hinged capsules, containing excessively minute powdery granules, the spores. These may easily be obtained by allowing the mature frond of a fern in autumn to wither up upon a sheet of paper in a dry place, when abundance of the spores will be shed from the sporanges as fine dust. The spores are microscopic cells, each with a double coat, resembling pollen-grains.

Some few British Ferns deviate from this type in the absence of an indusium, in the mode of arrangement, and in the form. and dehiscence of the sporanges.

Compare with the Type:-Common Polypody (Polypodium vulgare), simply pinnatifid fronds, with naked sori (no indusium): Hart's-tongue (Scolopendium vulgare), undivided, broadly linear fronds, with diverging linear sori on each side of the midrib: Hard Blechnum (Blechnum Spicant), with two kinds of simple pinnate fronds; some being 
barren (without any sori), the others with two linear sori, one on each side the midrib of each segment of the fiond: Common Brake (Pteris aquilina), with large branching fronds from a creeping rhizome,

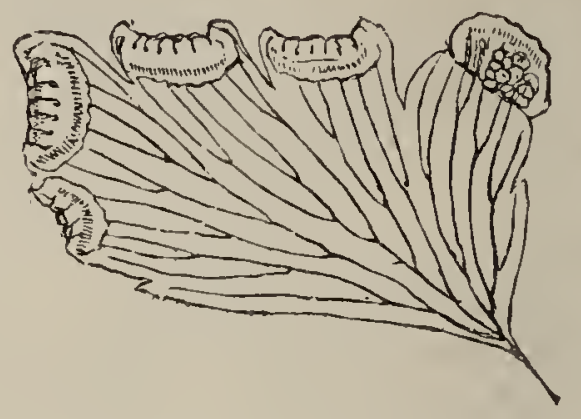

Fin. 196. Pinmule of Aliantum.

and narrow sori along the margin of the pinnules: Royal Osmund (Osmunda vulgaris), with the sporangia clustered on the upper divisions of the frond, forming a panicle, the lower portion of the frond being leafy and barren; the sporanges open across the top: Moonwort (Botrychium Lunaria), with a

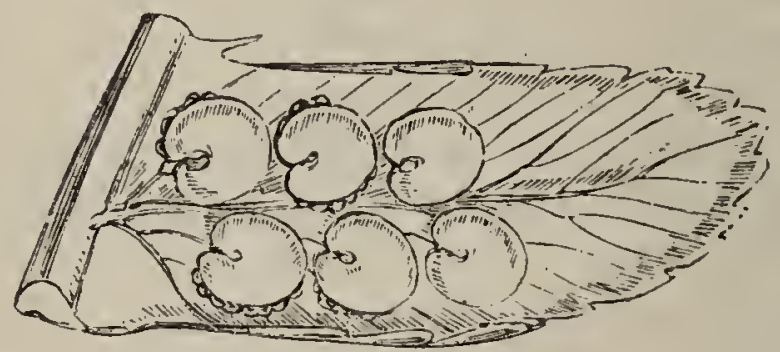

FIr. 197. Finnule of Aspidium.

sporange-bearing panicle or pinnate spike, distinct from the leafy frond, and the sporanges withont any trace of the hinge-like ring which usually sur- 
rounds them, partially or wholly, in other Ferns: and Adder's-tongue (Ophioglossum vulgaium), similar to Moonwort, but the leafy and fertile fronds undivided.

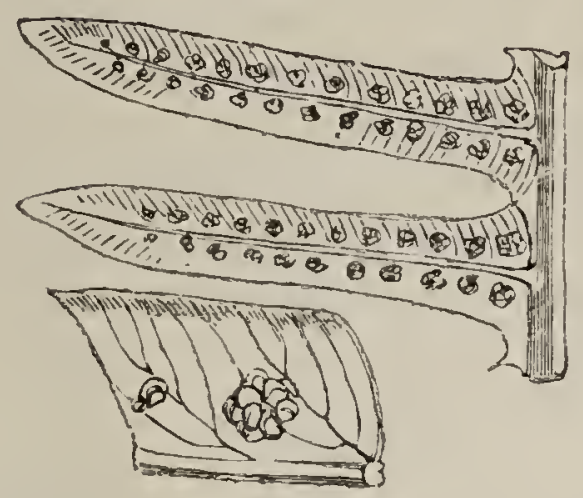

Hic. 195. Pimule of Polypodium.

The development of young Ferns from their spores may be watched by sowing the spores

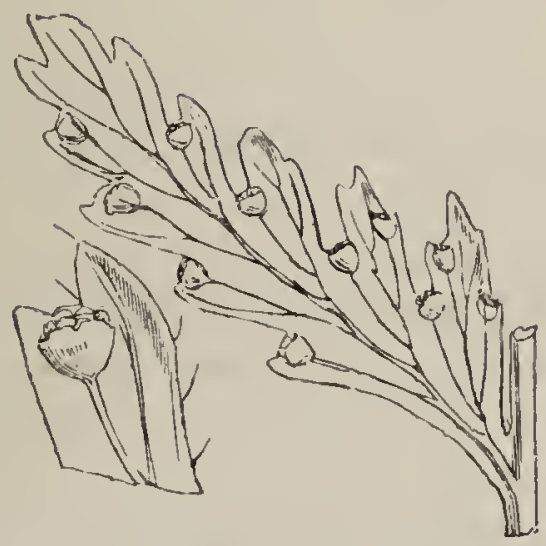

Fro 199. Pinnule and sorus of Hymenophyllum.

upon damp soil, covered by a bell-glass. From the grerminating spore arises a small, green, leafy 
expansion, called a prothallium, which gives off delicate root-fibres from its under surface. Upon the.same surface, scattered amongst these fibrils, especially on the thicker part of the prothallium, are several minute microscopic cellular bodies, of two distinct kinds. One kind, the more numerous, called antheridia, contain a number of extremely small vesicles, each of which contains a spirally-twisted filament, called

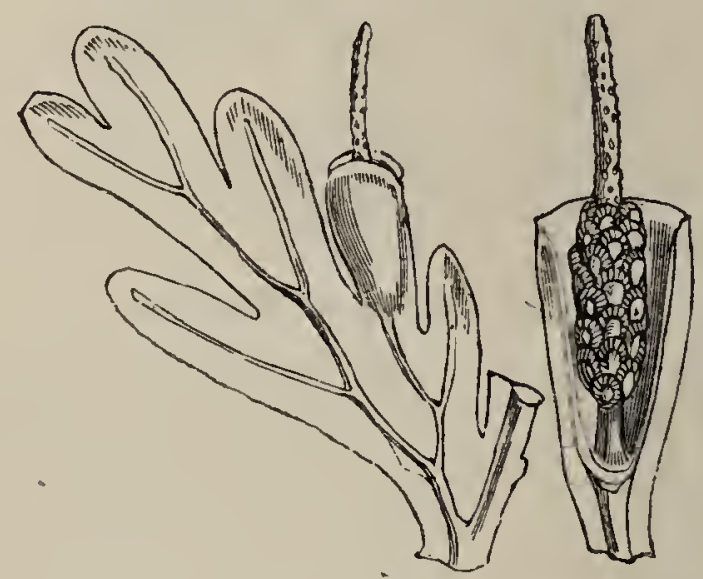

FIo. 200. Pinmule and scrus, laill open, of Trichomanes.

an antherozoid, which performs the function of a pollen-grain. The other kind, called archegonia, contain an embryo-sac, which is fertilized by the antherozoids of the antheridia, and the re. sult is the formation of a bud, which gradually develops into an independent Fern-plant. The antheridia and archegonia require a high magnifying power for their examination. Their true nature has been understood only within the last twenty-five year's.

Ferns are great favourites for parlour cultiva- 
tion under glass shades, which prevent the moisture which they require for their healthy growth from evaporating. Some foreign species, growing in warm, moist climates in the Suuthern hemisphere, form tall, woody sterns, 40 to 50 feet in height. These are called 'Tree-ferns.

The stem of Ferns differ's from that of both Dicotyledons and Monocotyledons, in its growing solely by additions to its summit, below which all the tissues are completed with their first formation, and in the arrangement of the fibrovascular bundles, which form an interrupted circle around a cellular axis, which usually decays away, so that old stems become hollow. From the mode of growth of Fern-stems, by snccessive additions to the extremity only, they have been termed Acrogens (point-growers).

The Common Brake-Fern (Pteris aquilina) is collected in hilly districts for litter, and one or two species are used in medicine.

2. Natural Order-Lycopodiaceæ. The Clubmoss Family.

Type-Lesser Club-moss (Lycopodium selaginoides).

A slender, moss-like plant, growing in wet, stony situations, 2 to 4 inches high, with narrow, pointed leaves, those on the erect fruiting branches bearing sporanges of two kinds in their axils.

There are six British species of Club-moss, and the small species which we have selected as Type differs from the rest in bearing two kinds of sporange. 
Common Club-moss, or Stag's-horn Moss ( $L$. clavatum) is very common on mountrin-sides and upper moorlands, as is also the Fir Clubmoss (L. Selago). The mode of reproduction of the species upon which but one kind of sporange has been found is not yet entirely cleared up. In

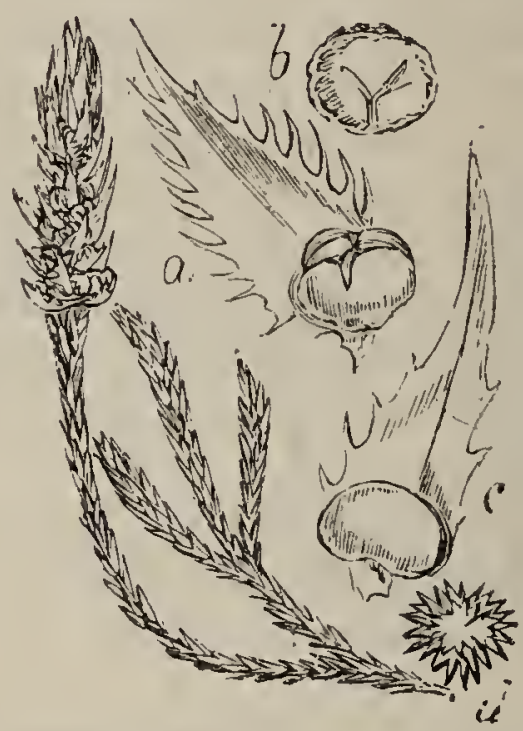

lir. 201. Lesser Club-moss. a scale with sporange containing larye spores (macrospores); $b$ single inacrospore; $c$ scale with sporange containing small spores (microspores); $d$ single microspore (magnified).

$L_{\text {: }}$ selaginoides the lower sporanges contain large spores, which, when sown, develop prothallia bearing archegonia. The minute spores from the upper sporanges develop antherozoids, which fertilize the archegonia, as in Ferns. In L. annotinum, a species bearing but one form of spore, both antheridia and archegonia develop upon the same prothallus. 
3. Natural Order-Equisetaceæ. The Horsetail Family.

Type-Field Horsetail (Equisetum arvense).

An herb, with a creeping rhizome, and erect jointed fertile and barren stems bearing minute teeth at the joints, representing leaves.

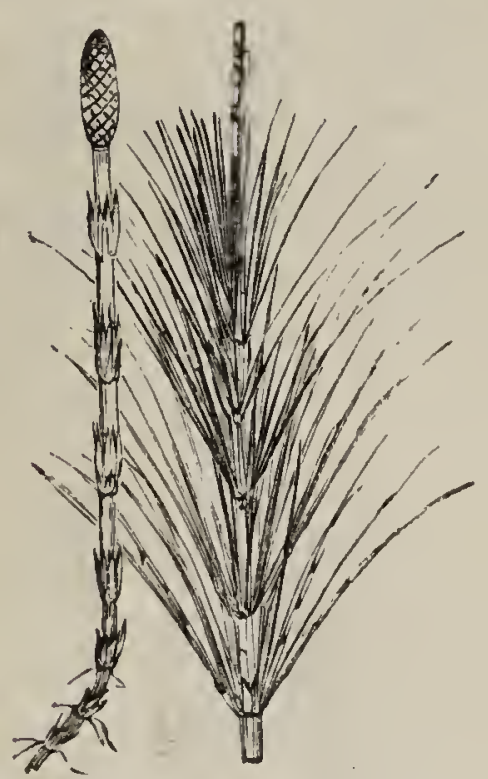

Fia. 202. Unbranched fertile, and branched barren fronds of Horsetail.

The fertile or fruiting stem is unbranched, 6 to 10 inches high, and withers in spring almost before the barren fronds appear. It bears a terminal, cone-like catkin, consisting of numerous closely packed peltate scales, upon the under margins of which are the sporanges, containing microscopic spores, mixed with elastic, hygroscopic filaments.

The barren summer fronds give off numerous slender, jointed branches, in whorls of 10 or 12. In some British species, the fruiting and 
barren stems are nearly or quite alike, and often both unbranched.

The development of young Horsetails from the spores is similar to that of Ferns. In one species, the Scouring or Dutch Rush ( $E$. hyemale), the epidermis contains so much silica, that bunches of the stem are sold for polishing metal.

4. Natural Order-Musci. The Moss Family.

Type-Hair-Moss (Polytrichum). Any species will serve.

Minute leafy plants, with slender stems, bearing sporanges upon erect, hair-like stalks (seto). They usually grow socially in tufts, or when more widely spread, in soft, carpet-like masses.

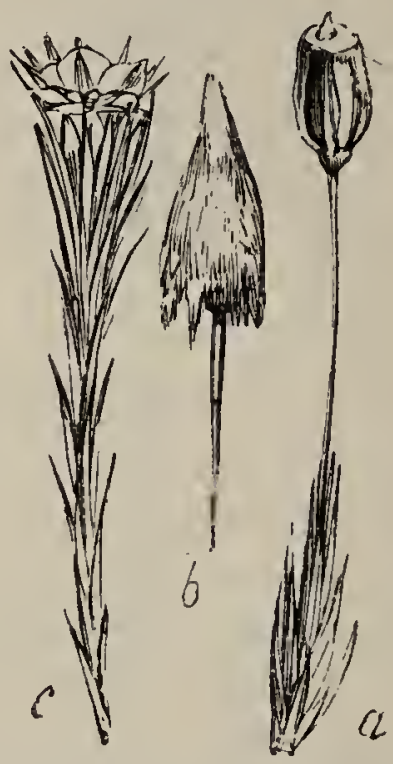

FIt. 203. Hair-Moss : $a$, seta bearing a eporange; $b$, sporange covered by its calyptra; $c$, head of antheridia, forming the male inflorescence.

The sporange is covered at first by a cap (calyptra), and is closed by a lid (operculum), which separates when ripe, exposing a row of 
minute teeth (forming the peristome) around the margin of the sporange.

The sporanges contain spores, which, when they germinate, develop the complete vegetative system-that is, rootlets, branches, and leavesof the Moss-plant. Upon the leafy branches antheridia and archegonia, analogous (though different in structure) to those of Ferns, are developed. From the archegonia, fertilized by the spiral antherozoids of the antheridia, arise the sporanges, usually borne up by a slender peduncle (the seta), and capped by the upper portion of the archegonium, which is torn away by the rising sporange, for which it forms the calyptra.

Other British Mosses differ in the position of the seta, in the mode of opening of the sporange, the presence or absence of a peristome, and the number of teeth which compose it, \&c.

In Mosses, vessels are absent from both stem and leaves; hence they-together with the plants grouped under the three following Families, all of which are destitute of vascular tissue-are termed Cellular Plants. Nearly all the plants which we have previously noticed, whether of Flowerless or Flowering Families, contain vessels, and are consequently termed Vascular Plants.

The species of Musci are very numerous, especially in cool and cold climates; and as many of them bear their fructification during the winter months, they may be collected and studied when Flowering plants are leafless or dead.

5. Natural Order-Fungi. The Mushroom and Mould Family. 


\section{'Type-Common Mushroom. (Agaricus cam. pestivis).}

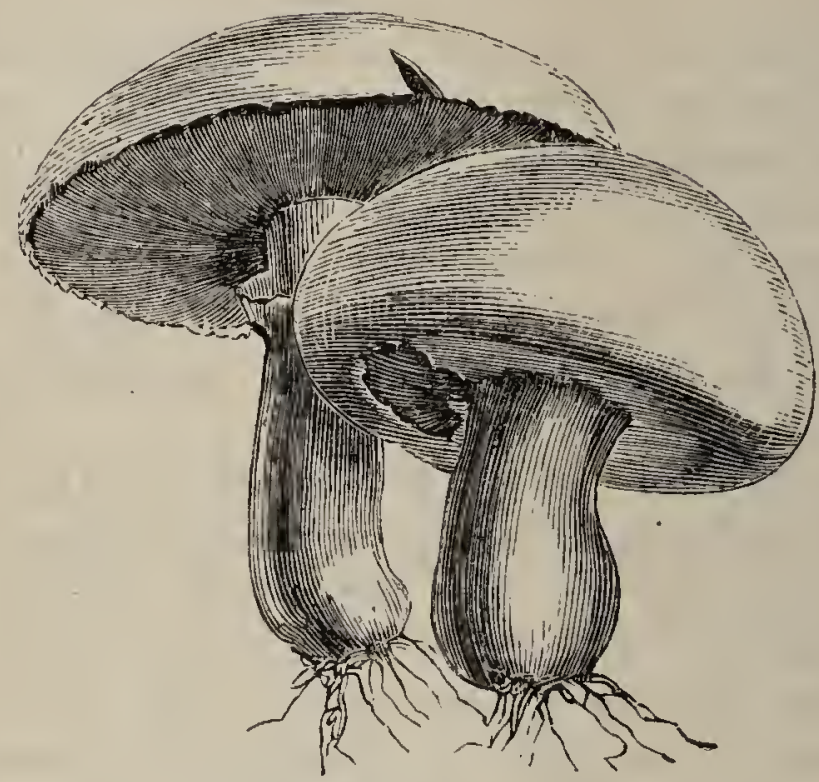

Fic. 201. Mushroom (Agaricus).

With a vegetative system growing under the surface of soil containing decaying organic matter, and consisting of a flocculent network of delicate cellular threads, forming what is called the mycelium. The fructification is borne above the surface, in the form of an umbrella-like disk, called the pileis, upon a stout stem. The margin of the pileus is at first united by a membrane to the stalk, from which it breaks away, leaving a ring-like scar. Upon the under side of the pileus, numerous vertical plates radiate from the top of the stem to the nargin of the pileus. If a very thin, transverse section of one of these plates be cut with a sharp knife, and examined under a powerful microscope, the surface will be found to be studded with large cells, each of which bears four very minute stalked 
spores upon its apex. Other Fungi depart very widely from this 'Iype, but nearly all agree in the absence of zrreen-colouring matter and of starch in their cells, and in their dependence upon decaying animal or vegetable matter for support. They are mostly short-lived, and often deliquesce when mature, though some, as the Touch-woods, are hard, woody, and persistent.

In many Fungi there is no distinction of stem and pileus, and the spore-bearing cells clothe excavations in the cellular substance of the Fungus (as in Puff-balls), or the spores may be formed in the interior of certain cells called asci, 2,4 , or more together, as in the subterranean esculent fungus called Truffle (Tuber cibarinm).

Some botanists divide the Fungi into two Tribes: (1) with the spores borne upon the exterior of cells called basidia, and (2) with the spores developed in the interior of cells called asci; those of the former Tribe being termed Sporiferous, those of the latter Sporidiferous. The variety in arrangement of the reproductive system of the Fungi is extreme, and there are very many species which are as yet very imperfectly understood.

Though a few of the Fungi are esculent, many are dangerous, and some poisonous. None should be eaten unless perfectly sound, and species with a disagreeable odour should be avoided. Many Fungi are very injurious, destroying large quantities of agricultural produce, timber, and miscellaneous substances, when circumstances favour their development. The Wheat Mildew, Smut and Bunt of Corn, Ergot, Hop-blight, the Moulds, and Dry-rot, are all Fungi. The Vine and 
Potato diseases are also due to the ravages of minute species, which multiply with great rapidity. As their spores are excessively minute, they cannot be excluded by any mechanical contrivance.

6. Natural Order-Lichenes. The Lichen Family.

Lichens occur either as crust-like or leafy expansions, or in little branching shrubby tufts, usually coloured grey, yellow, or greenish yellow. They spread everywhere over stones, brick-walls, the bark of trees, and even upon the niost exposed rocks of Alpine and Arctic climates, forming the very outposts of vegetation, and growing at the expenso, almost solely, of the atmosphere and the moisture which it bears to them. Unlike Fungi, they are long-lived and intermittent in their growth, being at a standstill, and often crumbling away, when the weather is dry. They differ, also, from Fungi in containing a green. coloured layer under the epidermis, consisting of cells called gonidia, which may be regarded as answering to the buds of higher plants, since, when set free, they develop new lichens, and thus multiply the plant. 'The true reproductive organs are contained in special receptacles, either exposed upon the upper surface of the lichen or buried in its tissue; the spores being contained in narrow cells similar, in some species, to the asci of Sporidiferous Fungi.

Several species, as Lecanora and Roccella, afford a valuable purple and mauve dye; and a few are edible, as the so-called Iceland Moss (Cetraria 
islandica). The Reindeer Moss (C'adoniba ran giferina) is a lichen, extremely abundant in polar regions, serving as food to the reindeer.

\section{Natural Order-Algæ. The Sea-Weed} Family.

This Family includes an enormous number of species, nearly: all adapted to grow under water, though by no means all marine, as many are wholly confined to fresh water. 'They vary to an extraordinary extent in size, form, and mode of reproduction. Some are microsicopic and individually invisible to the naked eye; whilst others, especially some marine species, attain a large size-a few, indeed, measuring some hunAreds of feet in length. The simplest forms consist of single microscopic cells; hence they are called Unicellular Algæ. These multiply by divi: sion and also by a kind of sexual reproduction, analogous to that of the higher plants, in which the contents of two distinct individual cells become commingled, and the resulting mass finally resolves itself into a number of new individual cells or plants.

Forms of a higher grade of structure are represented by the fine hair--like, filaments which we find floating in rivulets, water troughs, and wells, rooted at one extremity to stems or to larger water-plants. Many of these filamentous species (Confervoidece) multiply themselves by the contents of the cells which form their filaments, being resolved into innumerable minute moving bodies, called zoospores, which break out of the cells and rush about in the water until they finally settle down and grow.

'The higher species, such as the Olive-coloured 
Sea-weeds (Frucus), which clothe the rocks be tween tide-marks upon our shores, possess a complicated reproductive system of spores and antheridia, contained in thickened conceptacles at the extremities of the divided fronds. Their mode of reproduction, adapted to the medium in which the species grow, agrees in essentials with that which is characteristic of Ferns and Mosses; with this difference, however, that the spores themselves are directly fertilized and rendered capable of independent growth by the contact of the minute antherozoids contained in the antheridia.

The marine species vary in colour, some being usually olive, others red or green. The colour is employed as an aid in their classification.

For further details and illustration of the structure of the Algæ, I must refer to the excellent works of Professor Harvey.

Many species are used for food, and Fucus used to be burnt for the sake of its alkaline ash $(\mathrm{kelp})$ and for the iodine which it contains.

\section{How to Dry Plants.}

Specimens which are to be dried so that they may be kept in a Herbarium and referred to or examined at a future time, ought not to be gathered at random, but should be selected as average representalives of their species, unless they be designed to show some departure from the typical form. 'Tliey ought, if possible, to be taken up, when in flower, by the root, and the 
root should be pressed, if not too large, along with the rest. If the radical leaves be withered at the time of flowering, another specimen should be gathered at an earlier season to show them, as the radical leaves are often very different in form from those of the stem-as, for example, in the Harebell. Besides expanded flowers, the bud and ripe fruit should be shown; and if these cannot be had upon a single specimen, other examples should be collected, to show the plant in its different states. A strong knife or small trowel will be found useful to dig up the specimens.

The specimens should not be allowed to wither before reaching home. They may either be carried in a tin box, or loosely spread between sheets of paper in a portfolio. Fig. 205 shows a collecting portfolio, which may be made of two pieces of pasteboard sixteen inches long by ten inches wide, fastened, as shown in the cut, hy tape or straps. A few sheets of absorbing paper must be liept in the portfolio.

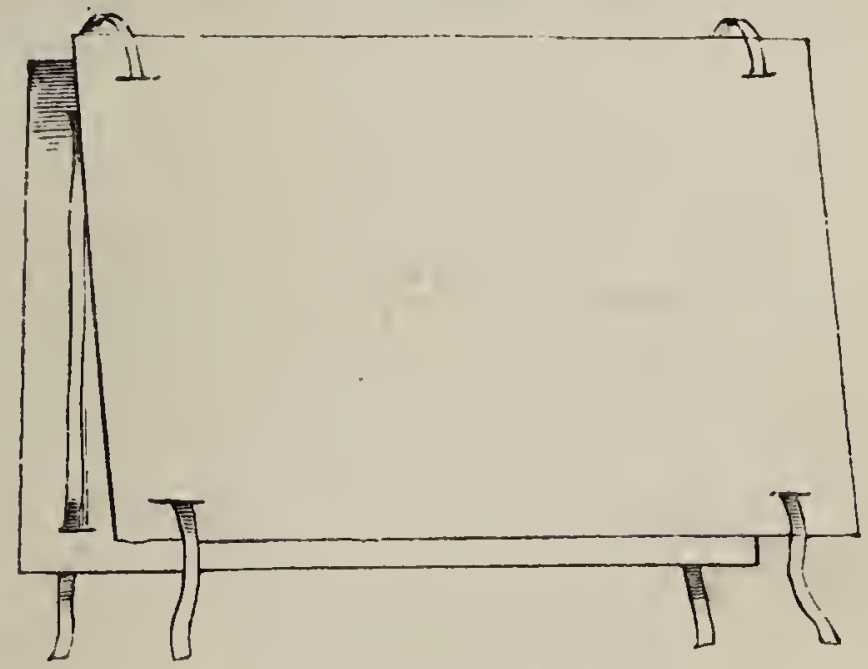

FIa. 205. Collecting Portfoiio 
In laying out the specimens for the press, use plenty of paper, so that their moisture may be quickly absorbed, and the danger of mould avoided. The specimens should be laid between the sheets of drying paper in as natural a position as may be, taking care not to crumple the leaves or flowers. If the specimens be too long for the paper, they may be carefuliy folded or cut in two. Delicate flowers should be carefully folded in paper. when gathered, and kept flat. Do not arrange every specimen just in the middle of the paper, but dispose them in such a way, that were a pile of them in their papers raised two feet high they would not topple over: this will equalizo the pressure. Several dry sheets ought to be laid between each layer of fresh specimens, the quantity of paper depending upon the thickness and succulence of the plants to be pressed. Pasteboards, or, better still, "ventilators" (made the size of the paper, of narrow strips of deal at short distances apart, nailed together in two layers at right angles to each other, as shown in the cut Fig. 206), may be introduced at intervals between

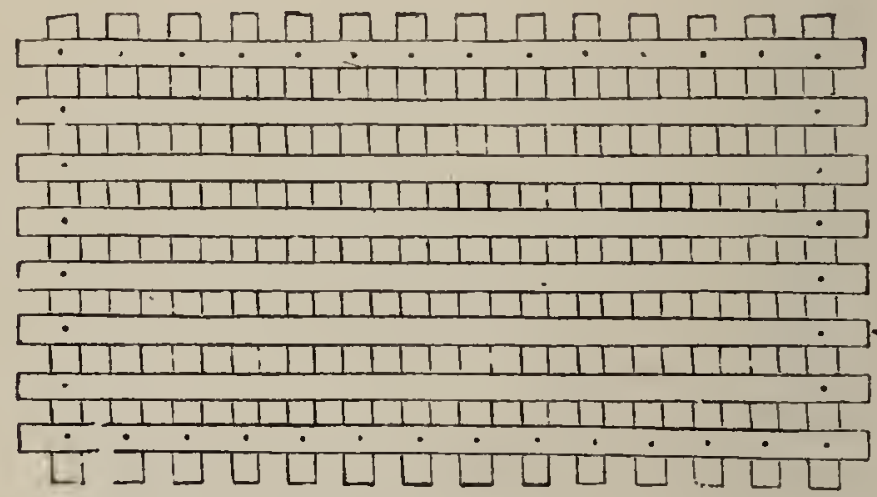

Fra. 200. Ventilitor. 
the layers of paper until the pile be ready for the press, which may consist simply of two stout boards, made so that they cannot bend or warp. Between these boards the paper and specimens must be placed, and a weight of stones or metal, not less than $50 \mathrm{lbs}$. or $60 \mathrm{lbs}$, laid upon the top.

The papers should be changed several times once a day, and then at longer intervals, until the specimers are quite dry, when they should be removed from the press. If fresh specimens be placed in the press, while others are in process of drying, they must be carefully separated by pasteboard or by a thick layer of paper. The length of time which specimens ought to remain in the press varies with their nature, whether dry or succulent, and with the kind and quantity of paper used. A good and cheap paper for pressing plants (17 ins. by 11 ins.) is sold by wholesale stationers, at about $17 \mathrm{~s}$. per ream.* Common stout brown paper, of the same size, which answers very well, costs about $14 \mathrm{~s}$. per ream. It may be cut to any size, but, generally, it should not be less than sixteen or eighteen inches long by ten inches wide. Practice will soon suggrest many little useful expedients in drying plants which it is needless should be detailed here.

The dried specimens should always be accurately labelled with the locality, name of finder, name of the plant, and any other details which may be thought desirable. They may either be kept loose in sheets of paper, or (and necessarily,

* Messrs. Spicer Brothers, of New Bridge Street, Blackfriars, supply the paper referred to. 
if intended for use in a sclool, or for frequent consultation) mounted upon sheets of stout cartridge paper of a larger size than foolscap, which may be obtained ready cut ( $16 \frac{1}{2}$ ins. by 10 ins.), at a cost of about $20 \mathrm{~s}$. to $24 \mathrm{~s}$. per icam. A ream consists of 960 half-sheets, sufficient for as many specimens.

The $s_{1}^{-p}$ ecimens should be fastened to the herbarium paper with hot glue, aboit the consistency of cream, the glue being laid on the specimens with a hair pencil. The newly-mounted sheets should be placed between waste paper or newspapers, and pressed over-night, before they are

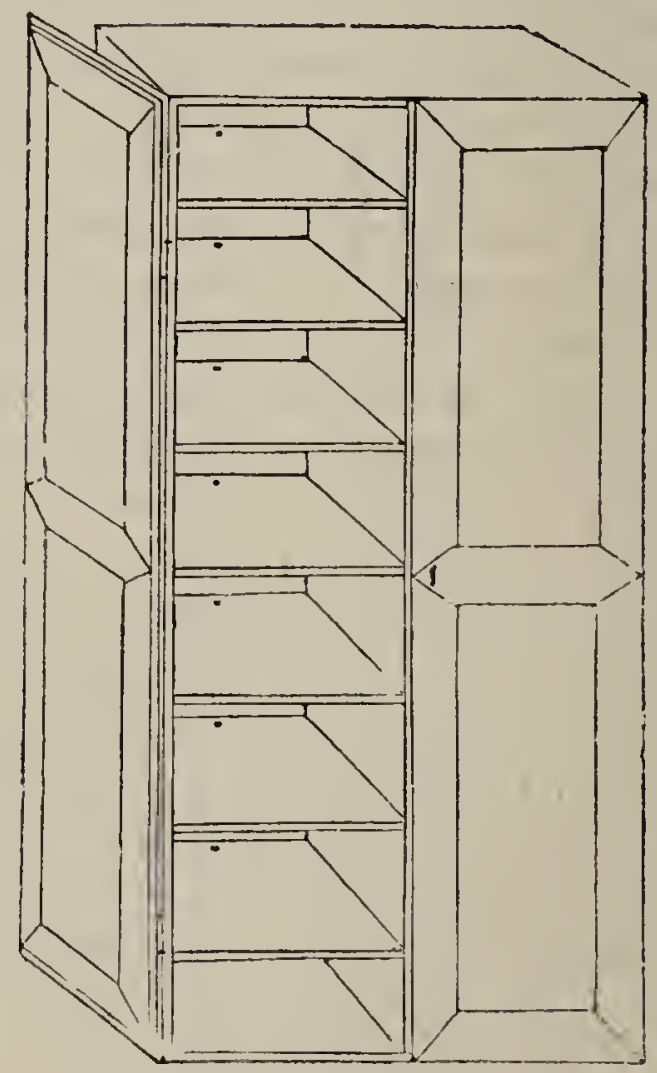

E'ı. 207. Herbarium Cabinct. 
finally retouched and placed in the Herbarium. Straps of gummed thin paper may be fastened over the thicker parts of the specimens, to prevent them breaking loose from the paper when accidentally bent.

The mounted specimens belonging to the same genus, or a part of them if the genus be a large one, may be placed in a folded sheet of a stronger and coarser paper than that upon which the specimens are glued; upon this cover, at the bottom, the name of the genus and of its Natural Order may be marked. The genera should be arranged in their Natural Orders, the Natural Orders in their respective Divisions and Classes, and the whole placed in a suitable cabinet, which, however, need not be procured just at first.

Whatever the form of the cabinet in which the Herbarium is kept, it should be securely closed, so as to exclude dust, and camphor should be placed upon the shelves, unless the specimens are well washed over with a preservative solution before being laid in. * The preceding cut shows an excellent form of cabinet, made of deal, similar to those in use at the Herbarium of the Royal Gardens, Kew.

* The preservative solution may consist of corrosive sublimate dissolved in spirits of wine, in the proportion of two drachms to the pint. It is very poisonous, and should be kept labelled, and used with care. 



\section{APHENDIX.}

\section{HOW TO DESCRIBE PLANTS.}

WHeN the student has acquired facility in filling up schedules from plants belonging to all the principal divisions of Phanerogamia, it is desirable that he should proceed to describe specimens more at length, as shown in the following examples. As the principal use of the schedules is to direct the attention to certain important points of structure, care nimust be taken never to omit reference to these iraportant points in describing plants in this way. If', however, as is best, the description be headed with the Class and Division to which the plant belongs, it is not necessary (excepting in Examination e:cercises) to detail all the characters which are inplied by referring it to such Class and Division. The organs must be described seriatim in the order of their development.

\section{Commoii Wallelower. Cheiranthus Cheiri.}

Class Dicotyledons. Division Thalamifloræ.

A . herbaceous plant, somewhat woody below, with alternate entire exstipulate leaves, and racemose ebracteate flowers.

Rоот biennial, woody, branched.

STEM erect, branched, leafy, slightly angular, hoary at first with minute adpressed hairs, glabrescent.

LEAVES cauline, alternate, linear-lanceolate or lanceolate, acute, attenuate below, entire or slightlytoothed, glabrous, exstipuliate.

RACEMES terminal, erect, many-flowered. 
FLOWERs regular, ebracteate.

CALYX inferior, polysepalous, deciduous ; sepals 4 , lanceolate, anterior and posterior gibbous at base.

corolla cruciate, yellow or reddish brown; petals clawed, limb obovate, claw linear.

STAMENS tetradynamous, erect; filaments filiform ; anthers lanceolate, 2-celled, introrse, dehiscing longitudinally.

PISTIL syncarpous, superior ; ovary linear, slightly compressed, spuriously 2-celled; style terminal, short ; stigma 2-lobed; ovules indefinite, parietal.

FRUIT a linear siliqua; seeds indefinite, pendulous, compressed, exalbuminous ; embryo with a curved accumbent radicle.

\section{Garden Pea. Pisum Sativum.}

Class Dicotyledons. Division Calycifloræ.

A weak climbing annual herb, with alternate stipulate compound leaves ending in tendrils, and irregular (papilionaceous) flowers.

ROOT fibrous, branched.

STEM weak, climbing, slightly branched, glabrous.

LEAVES cauline, alternate, pinnate (bi-tri-jugate), terminating in tendrils (metamorphosed leaflets); leaflets ovate, entire, glabrous, glaucous ; stipules foliaceous, ovate-cordate, slightly crenate.

FLOWERS large, irregular (papilionaceous), in 23-flowered, axillary, pedunculate racemes. tent.

CALYX gamosepalous, 5-toothed, bilabiate, persis-

COROLLA papilionaceous, white ; vexillum large, broadly obcordate, erect ; alo roundish, converging, shorter than the compressed, curved carina.

STAMENS perigynous, decandrous, diadelphous ; filaments subulate above ; anthers 2-celled, dehiscing longitudinally.

PISTIL apocarpous, monogynous ; ovary superior, oblong, compressed, 1-celled ; style terminal, subfal 
cate; stigma simple; ovules few, attached to the ventral suture.

FRUIT a legume; seeds few (3-9), globose, exalbuminous, with a coriaceous, glabrous testa.

\section{Common Heracleum. Heracleum Sphondylium.}

class Dicotyledons. Division Calycifloræ.

A coarse erect hairy herb, with fistular stem, much-divided leaves with dilated sheathing petioles, and small white flowers in terminal compound umbels.

RоOT rather fleshy, tapering, sub-perennial.

STEM erect, branched, fistr:lar, terete, furrowed, rough with spreading hairs.

LEA VES large, radical and cauline, alternate; petiole broadly sheathing; blade pinnatifid or bipinnatifid, segments usually lobed and toothed, pubescent.

UMBELS terminal, compound ; involucre 0 or of few, lanceolate, acute bracts ; involucels of several linearlanceolate, acute bracteoles.

FLOWERS hermaphrodite, irregular, white or tinged with red.

CALYX gamosepalous, superior ; limb minutely 5toothed.

COROLIA polypetalous (outer petals larger); petals obcordate, apex inflexed.

STAMENS epigynous, pentandrous ; filaments filiform ; anthers ovate, bilocular, dehiscing longitudinally.

PISTIL syncarpous, digynous ; ovary inferior, 2celled ; styles 2 short, erect ; stigmas terminal, sinple ; ovules one in each cell, pendulous, anatropous.

FRUIT a cremocarp, pubescent or nearly glabrous ; mericarps dorsally compressed, broadly oval, slightly winged, with 5 slender primary ridges ; vitto solitary in the interstices, clavate, not reaching to the base of the mericarps; seeds one in each cell, albuminous; embryo with a superior radicle. 


\section{Common Ivy. Hedera Helix.}

Crass Dicotyledons. Division Calyutloræ.

A climbing evergreen shrub, with coriaceous shin. ing leaves, and inconspicuous umbellate yellowishgreen flowers.

STEM climbing, emitting numerous short adventitious rootlets by which it adheres to objects over which it climbs; flowering branches forming large bushy heads, the young shoots puberulous, at length glabrous.

LEAVES cauline, alternate, petiolate, exstipulate, coriaceous, glabrous, shining; of the flowering branches lanceolate, ovate, rhomboidal or deltoid, with rounded angles, entire or slightly lobed; of the barren branches cordate at the base, usually 3-5-lobed, lobes acute or obtuse.

FLOWERs hermaphrodite, regular, in paniculate or racemose globose umbels.

CALYX gamosepalous, superior; limb nearly obsolete, minutely 5-toothed.

COROLLA polypetalous; petals 5 , at length reflexed, ieciduous.

STAMENs epigynous, pentandrous; filaments subu. late; anthers 2-celled, dehiscing longitudinally:

- PISTIL syncarpous, monogynous; ovary inferior, 5-celled ; styles very short, connate; stigmas simple, obtuse ; ovules solitary, pendulous, anatropous.

FRUIT a globose berry, 1-5-celled, 1-5-seeded ; seeds albuminous, albumen ruminated; embry with a superior radicle.

Common Primrose. Primula vulgaris. .

chass Dicotyledons. I Ivivision Corolliflore.

A perennial acaulescent herb, with simple radical leaves, and pale sulphur-yellow flowers on slender scapez. 
ROOT of several stout fibres, from a short, flesliy, subterranean, perennial rhizome.

LEAVES radical, tufted, obovate-oblong or oblanceolate, toothed, rugose, slightly pubescent, nearly sessile, exstipulate.

FLOWERS regular, hermaphrodite, on slender, erect or ascending, pilose, I-flowered scapes.

CALYX inferior, gamosepalous, slightly inflated, 5-fid, with acute teeth, persistent.

CUROLLA hypocrateriform; tube exceeding the calyx ; limb 5-lobed, lobes obovate, emarginate.

STAMENS pentandrons, epipetalous, opposite to the lobes of the corolla (inserted either at the top of the tube above the stigma, or near the middlo of the tube and below the stigma); filaments short; whthers erect, oblong, 2-celled, dehiscing longitudivally.

PISTIL syncarpous, monogynous ; ovary superior, globose, 1-celled; style terminal, erect, filiform : stigma capitate; ovules indefinite, upon a free central placenta.

FRUI'T a capsule, dehiscing by teeth; seeds indefinite, angular, albuminous; cmbryo minute.

\section{Ragworti Senecio. Senccio Jacobrea.}

CLAss Dicotyledons. Division Corolliflorre.

A perennial herb, with much divided simple leaves, and terminal corymbose heads of yellow florets.

roo' fibrous, from a short, fleshy, perennial rootstock.

STEM annual, erect, 2-4 feet high, branched, leafy, furrowed, glabrous or sparsely tomentose.

LEAVES alternate, radical and cauline; radical leaves Iyrate-pinnatifid, cauline pinnatifid, segments pin. natifid or coarsely toothed, glabrescent, exstipulate.

CAPITUIA heterogamous, pedunculate, peduneles nsually cottony ; involucre hemispherical, of numerous (13--15) oblong-lanceolate, subacute, equal bricts: 
outer scales lax, minute; receptacle flat or slightly :onvex, naked; florets numerous, yellow ; of the disk regular, hermaphrodite, of the ray irregular, pistillate.

CALYX gamosepalous, superior, limb pappose.

COROLLA (of the disk-florets) tubular, 5-toothed, (of the ray florets) ligulate, spreading, 3-toothed.

STAMENS pentandrous, epipetalous; filaments filjform, epipetalous; anthers syngenesious, linear, 2celled, dehiscing longitudinally.

PISTIL syncarpous; ovary inferior, I-celled; style filiform; stigma bifid; ovule solitary, erect, anatropous.

FRUIT an achene with pilose pappus; seed solitary, erect, exalbuminous; embryo with an inferior radicle.

Сомmon Beech. Fagus sylvatica.

CLASS Dicotyledons. Division Monochlamydeæ.

A large, deciduous tree.

BRANCHES flexuose, slender, terete, reddishbrown, glabrous.

LEAVES alternate, petiolate, simple, elliptical or ovate, denticulate-serrate or nearly entire, sub-acute, shining, with sparse silky hairs when young, glabrous at length, secondary veins straight, parallel, reaching to the margin ; petioles short; stipules scaly, linearlanceolate, cadiccous.

FLOWERS axillary, monœcious :--male flowers in pendulous, pedunculate, subglobose, silky catkins ; perianth cimpanulate, multifid, lobes acute; stamens about $9(5-12)$, exserted, filaments filiform, anthers oblong, 2-celled, dehiscing longitudinally ; pistil 0:female flowers usually in pairs enclosed in an erect, shortly pedunculate involucre, covered with subulate silky scales; perianth gamophyllous, superior, limb minutely toothed; stamens 0 ; ovary inferior, syncarpous, triquetrous, 3-celled ; styles three, subulate, spreading; stigmas linear, lateral; ovules 2 in each :ell, axile. 
ERUITS ovoid, acutely tringetrons, 1-celled, usually in pairs, enclosed in a silky 4-valved rather prickly involucre with the valves at length recurved; seeid solitary, exalbuminous; embryo with a superior radicle.

\section{Spotted Orchis. Orchis maculata.}

class Monocotyledons. Division Petaloider.

A glabrous unbranched herb, with sheathing leaves, and a terminal dense spilie of pale purple or nearly white blotched irregular flowers.

гоoт of two fleshy 2-or 3-labed, flattened, anmuil tubers, and a few simple fibres.

STEM erect, succulent, ilbout 1 foot high, leafy.

LEAVES radical and cauline, alternate, sheathing, ovate-lanceolite or linear-linceolite, acute or obtuse, glabrous, usuilly marked with blackish blotches above.

FLowers hermaphrodite, densely spicate, bracteate; bracts linear-lanceolate, acute, exceeding or equalling the ovary.

PERIANTII irregular, superior; three onter leaves (sepals) oblong-lanceolate, lateral sepals oblique, asscending; three inner leaves (petals) unequal, laterat petals ovate, obtuse, connivent, lower petal (labellum or lip) 3-lobed, plane or with the margins reflexed, lateral lobes usually lirger, crenulate, obtuse, central lobe ovate or oblong, obtuse; spur slender, rather shorter thim the oviry.

COLUMN slort; anther erect, 2-celled, dehiscing in front, pollen-masses 2 , each with a caudicle and distinct gland, the latter embedded in the projecting rostellum.

OVARY inferior, twisted, I-celled; stigma concave. immediately beneath the rostellum; ovules indefinite, parietal, in 3 rows.

FRUIT a capsule, dehiseing in 3 valves cohering at base and apex; seeds indefinite, minute, exalbumi. nous ; embryo acotyledonous. 


\section{Common Wheat. Triticum vulgare.}

Class Monocotyledons. Division Glumiferie.

An annual corn-plant, with erect, distichous, spicate inflorescence.

RoOT fibrous.

STEM erect, jointed, terete, striate, glabrous.

LEAVES cauline, alternate, sheathing, linear, acu. minate, striate, slightly scabrous above; sheath terete, striate, glabrous; ligule very short, truncate, nembranous.

INFLORESCENCE spicate, 3-4 inches long, tetrigonous, rachis compressed, ciliate ; spikelets alternate, distichous, compressed, 5-9-flowered, sessile, attached by their sides to the rachis.

OUTER GLUMES nearly equal, coriaceous, ovate, ventricose, obliquely subcarinate, obtuse, apicnlate, glabrous.

FLOWERING GLUME ovate-oblong, coriaceous, ventricose, obscurely $7-9$-nerved, aristate.

PALE equalling the flowering glume, narrowly oval, obtuse, bicarinate with inflexed margins, angles minutely ciliate.

STAMENS triandrous, hypogynous; filaments capillary; anthers versatile, linear, bilocular, dehiscing longitudinally.

\section{LODICULES 2.}

PISTIL syncarpous ; ovary superior, 1-celled, globose; styles 2 ; stigmas plumose ; ovule solitary.

FRUIT a free caryopsis; cmbryo at the base of mealy albumen.

N.B.-Wheat occurs under many varieties, as indeed do several of the plants which I have de. scribed above in brief. The varieties of wheat differ in the presence or absence of an awn to the glumes, und in other trivial characters. 


\section{INDEX AND GLOSSARY.}

Akics, 256.

Abortion, imperfect or rudimentary development.

abrupt, applied to organs terminating suddenly.

Abrus, 172.

Absorption, 15.

Acacia, 172.

acaulescent, apparently stemless.

accrescent, applied to parts of the calyx or corolla which persist and enlarge after flowering, 231. accumbent, 143.

Acerince, 161.

Achenc, 97.

Achlamyrlese, 248 .

achlamydeous, without either calyx or corolla, 40.

acicular", 75 .

Aconite, 131.

Aconitum ferox, 132.

Acorn, 95.

Acotyledons, 293.

Acrogens, 299.

Aculei, prickles ; aculcate, prickly. Acumen, a lons narrow point; acuminate, having an acuncu.

acute, 79.

Adam's Needle, 269.

Adler's Tongue, 297.

Adhcsion, 27.

adnate, adherent ; also applied to anthers with the filament prolouged up the back of tlie anther.

Egilops, 287.

aerial (roots), 66.

Asculus, 162.

Astivation, 86.

Agaricus, 304.

Agave, 279.

$A$ loe, wings (of papilionaceous corolla, 16s); alate, winged.

Albumen, 10. albuminous, 45, 102.

Alburnum. See Sap-wood

Alder, 249.

Algæ, 307.

Alisma Family, 264.

Alismacex, $\mathbf{4 0 4}$.

Alkanet, 220.

Alnus, 249.

Aloe, American, 279.

Aloes, 269.

Alopecurus, 254 .

culternate, 69.

Amarylliclea, 278.

Amaryllis Family, 278.

Ament, 246.

Amentaceæ, 246.

American Aloe, 279.

amplexicaul, 79 .

anatropous, applied to oviles when inverted, so that the micropyle adjoins the hilum, and the organic base of the uncleus (where it is united to the coat or coats of the ovulc) is at the extremity remote from the hilum.

Ancluusa, 220.

Androcium, the stanens of a flower collectively.

-androus, in composition, applying to the stamens.

Auemone, 130.

angiospermous, 253.

Angiosperms, plants having the orules and secds enclosed in an ovary.

Anise, 190.

annual, producing seed and dying in the first season.

annual (zones), 116.

antcrior, same as inferior, when applied to the relation of the parts of a flower to the axis. Anthar, 8, ISI 
Antheridiun, the male organ of Cryptogams, eorresponding to the anther of Phanogams, 295. Anthoxanthum, 2S4, $2 \mathrm{SG}$.

Antiaris, 243.

Antirilinum, 224.

apetalous, witlout petals (or corolla).

Apex, 79.

apiculate, wilh a small abrupt point (upiculus).

apocarpous, 10.

A porynacer, 215.

A pothiccium, the fructifieation of Lichens nsually apulied to the open, slield-like disks bearing tlic tlieex.

Apple, 31, 96.

Aquifoliaeere, 164.

Anaclis, 169.

urachinoid, like cobwebs.

A ralia Fruily, 190.

Araliacere, 190.

Archangel, 159.

Archegonium, the female organ of Cryptograms, eorresponding to the orule or embryo-sae of Plianograns, 2!S.

Arenaria, 14S.

Aril, ol arillus, a eoat growing pa!tially or wholly over the testa of certain seeds, developed fion the funicle or micropyle. An aril developed from the miciolyle is sometimes distinguished as an arillode, 164.

aristatc, lnaving an awn.

Armeria, 229.

Aroidere, 258.

Arracaclia, 190.

Aitichoke, 206.

Articholie, Jerusalem, 205.

Artocarpus, 243.

Arum, 47.

Arum Family, $25 \mathrm{~S}$.

Ascending axis, 12.

Ascending sap, 1 is.

Asci, 305.

Aseel jias Family, 216.

$A \operatorname{sh}$ (of plant6), 16 .

Ash, $21 \%$.

Ash, Flowering, 213, 214 .

Ash, ll ecping, 214.

Aspar:?us, 268 .

Asperula, 195.

Asphodel, 269
Aspiclium, 294.

Assimilation, 18.

Astragalus, 170.

Astrantia, 189.

Atriplex, 231, 232.

Atropa, 221.

Aubergine, 222.

Auvicle, an ear-like appendage;

auriculate, witl anricles.

Avena, 2S4, 289.

A $u n, 53$.

axillary, 67.

Axis, $1 \%$.

axile, 93 .

$\Delta z$ zalea, 209.

Batehelor's Button, 131.

Balm, 227.

Balsam of Peru, 171.

Baniboo, 2n1.

Bambusa, 291.

Baneher'y, 131.

Banyan, 243.

Barberry Family, 132.

Barilla, 232.

Jark: 117, $11 \mathrm{~s}$

Barley, 2S4, 285, 2SS.

Base, 70.

Basiclia, 205.

Basil, 2:7.

Batatas, 2 Is.

Becti (of Gelaniums), 159.

Bean, 42, 168 , 169.

Berleguars (of Rose), 176.

Beechl, 247 ; described, 320.

Beet, 232.

$\mathrm{B}$ - groniacea, $15 \%$.

Bell-flowers, 207.

Berbericlea, 132.

Berry, 97.

Beta, 232.

B tulacese, 248 .

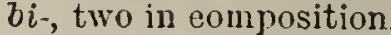

bilentate, with two teeth.

bimnial,produeingseed and dying in the second season.

bifill, 79

bifoliolate, with two leaflèts.

Rikh poison, 132.

Bilbery, 209.

bilocular, two-celled; apylied to anthers and ovaries.

Binlweed, 218.

bipcrtite, 79 .

bipinnate, 78 . 
Birch Family, 248.

Birci's-foot, 170.

Bistort, 232.

biternate, 79.

Bittersweel Solnumm, 220.

Blackberry, 30, 9S, 174.

Blade, 5.

13lechnum, 2.95.

Blucbottle, 202.

lioehneria, 241.

Borage Fanily, 21.

Boraginen, 219.

Botryehium, 296.

Botrytis, 22:.

Box, 239.

Bract, bracteate, S5.

Bractcole, tleesmall bract of an indivirlual flower of an intloreseenee.

Bratie, 296, 299.

Bramblc, 30, 95, 99.

Brassica, $1+3$

Brazil-wood, 171.

Biearl-finit, 243 .

Broom, 169.

Bronssonetial, 243.

Bryolly, 1 so.

Bryouy, Black, 279.

Bryoplithum, is3.

Buckbean, 217.

Burthorn Family, 105.

Buckwheat, 232, 233.

Burel, 6, 6i7.

Bulb, bs, ens.

Bullels (of Figwort Ranunculus), 131 ; of liliuun, 268.

13i11t, 305

Bumya-lumya, 2.57.

Bupleminu, $18 s$.

I3utchel"s B3100m, 268.

I3utoli1us, 265.

Jutter(11), 1, 27.

Buxus, 230.

Bjottueriaces, $15 S$.

Gabinet, $\$ 12$.

caducune, alpulied to nrgans of the flower wlich fall off, at or before the time of expansion.

Casalpiniex, $16 \mathrm{~s}$.

crespitose, tufied.

Calceolaria, 225.

calccolate, slipper-sliaped.

Calenrlula, ¿03.

Calla, 260.

Calyciflora, 5S, 163.

Calyptra, 312 .
Calyx, 7.

Cam-wood, 171.

Cambinm, 114, 117.

Camellia, 151.

Campanula Jamily, 207.

Campanulacer, 207.

campanulate, bell-slaped.

campylotropons, applied to ovules when the nucleus and its conts are curved so as to luing the micropyle near to the hilum and to the organic base of the nueleus.

Canary-flower, 160 .

canescent, loary with minute nairs, giving the surface a whitish hue.

Cammalis, 240.

Cantrhouc, Binzilian, 238.

capillary, hair-like.

Cupitulum, a flower-head, 35, 84.

Caprifoliacere, 193.

Calusicuri, 222.

Capsule, 97.

Caraways, 190.

Carbonic aciul gas, 17.

Carloon, 206.

Carduus, 200.

Carex, 2S?.

Curina, a keel (of paplionaceous corolla, 16?).

carinate, liceled.

Carnation, i47.

Cirob, 172.

Campel, 9

Carpinus, 247.

Calrion-Howers, 216.

Cirriot, 159.

Cauthamms, 200

Caryophyllacer, 140.

Caryopsis, 286.

Cassava, 2:3s.

Cissia Fistula, 170.

Castanea, 247.

Castor-oil, 239.

Catechu, 173

Catkin (or ament), a deciduous spike, $39,246$.

Candicle, $2 \div 3$.

cauline, 5 .

Cayeme Pepper, 222.

Celar, 255, 25 i.

(Celandine, 137.

Celastraceæ, 163.

Celistrus Fanily, 163.

Celery, 189.

Cell-contents, 108. 
Cells, 105 ; growth and division of, 109.

Cellular plants, 303.

Ccllular systcm, 112.

Cellulose, 109.

Centaurea, 202.

Centranth, 198.

centrifugal, same as definite, applied to an inflorescence, 85 .

ccintripetal, same as indefinite, applied to an inflorescence, 85 .

Ceratonia, 172.

Cercis, 170.

crrnuous, pendulous, overhanging.

Cetraria, 307.

Chalaza, the part of an ovule where the base of the nucleus is united to its coats.

Thamærops, 262.

thamomile, 203, 205.

Chenopodiacex, 230.

Chenopodium, 231.

Cherry, 95.

Chestnut, 246; Horse Chestnut, 163.

Chicory, 206.

Chlora, 217.

Chlorophyll, $\mathbf{3 1 1 .}$

Chrysanthemum, 205.

Churras, 241.

Cichnrium, 206.

Cicuta, 190.

ciliate, fringed with hairs.

Cinchona, 197.

Cinenchyma, branching vessels containing white or coloured fluid (milk-sap).

Cineraria, 206.

circinate, 294.

Circulution of san, 118.

circumscissilc, dehiscing transversely; applied to capsular fruits.

Cistaceæ, 144.

Cistus Family, 144.

Cladodia, 268.

Cladonia, 307.

Ciassification of plants, 122.

cirvate, club-shaped.

cleww, 86 .

Cleavers, 197.

Clematis, 130 .

Clover, 168.

Clubmoss Family, 299.

Coccus, the 1-seeded carpel of a syncarpous fruit, the carpels of which separate from each otker wlien ripe.

Cocoa, 155 .

Cocoa-nut, 263.

Coffee, 196, 197 .

Cohesion, 27.

Coir fibre, 263.

Collecting specimens, 30 S.

Collcctive fruits, 99.

Colocasia, 259.

Colocynth, 182.

Coltsfoot, 204.

Columbine, 131.

Columella, the central organ in the sporange of mosses.

Column, 272, 273.

Commissure, 188.

complete, applied to flowers when calyx, corolla, stamens and pistil are present.

Compositx, 200.

Composite Fanily, 200.

Compound leaves, 74 .

Conccptacle, a closed cavity containing fructification in cryptogams, 308.

conduplicate, folded down the middle.

Cones, 100.

Confervoidea, 307.

Coniferæ, 251.

Conium, 190.

connatc, 79 .

Connective, the portion of the anther connecting the pollenbearing lobes. Of Salvia, 226.

contortcd, twisted.

Convolvulaceæ, 217.

Convolvulus Family, 217.

convolute, applied to leaves rolled inwards from one edge.

Copal, 171 .

Coquilla nut, 263.

cordate, 75 .

coriaceous, of leathery consistence.

Corianders, 190.

Cork, 248.

Corm, 68.

Corn-salad, 198.

Cornaceæ, 192.

Cornel Fanily, 192.

Cornus, 193.

Corolla, 7.

Corollifloræ, 193.

Corona, 50.

Corylaceæ, 244. 
Corylus, 245, 246.

Corymb, S3.

Cotton, 156.

Cotton Sedge, 281.

Cotyledon, 43, 55 .

Cow-parsnip, 32, 186.

Cow-wheat, 225.

Cowbane, 190.

Cowdi Pine, 256.

Cowslip, 210.

Cranberry, 209.

Crane's-bills, 159.

Crassulaceæ, 182.

Cremocarp, 187.

crenate, so.

Crocus, 277.

Croton-oil, 239.

Crown Inıperial, 269.

Crucifer Fannily, 139.

Cruciferæ, 139.

Cryptogamic plants, 292.

Cuclioo Pint, 47.

Cucubalus, 147.

cucullate, hooded.

Cucumber, 1 S1.

Cucurbitaceæ, 180.

Cudweed, 203.

Culm, 283.

Cumin, 190.

cuneate, wedge-sliaped.

Cupressus, 253, 255.

cupular, cup-shaped.

cupule, the cup-like involuere of Corylaceæ.

Currants, 184.

Cuscuta, 21 S.

cuspidate, witl an abrupt, acute point.

Cyclamen, 211.

Cyme, cymose, š́.

Cyperaceæ, 281.

Cyperus, 283.

Cypress, 253, 250.

Cypripedium, 275.

Daffodil, 278.

Dahlia, 206.

Daisy, 33, 201.

Danmara, 256.

Dandelion, 200, 201, 206.

Darhne Fainily, 234.

Date Palın, 262.

Datura, 221.

Deadnettle, 36, 225.

Deal, 256.

deca-or decem-, ten in compositiun. decandrous, 61.

cleciuluous, 7.

declinate, applied to stamens when directed to one side.

decambent, applied to stems horizontal at first, then rising from the ground towards the inflorescence.

decurrent, 79 .

decussate, with opposite pair:s alternating at right angles.

definite, inflorescence, 85: seetls, or ovules, 102 ; vuscular bunules; 113.

dehisce, dehiscent, 96, 97.

Dentaria, 142.

dentate, So.

denticulate, finely-tnothed.

Descending axis, 12.

Describing plants, 315.

determinate, applied to an inflorescence which is lefinite, centripetal, or cymose.

di-, two in composition.

diadelphous, 30.

diandrons, 61.

Dianthus, 147.

Dicentra, 139.

Dichlamydex, 57, 129.

dis.lumydeous, witl calyx and corolla. 21.

dichotomous, forked.

diclinous, Howers with stamens only, or with pistil only.

dicoccous, applied to syncarpous fruits consisting of two cocei.

Dicotyledons, 46,57 ; classification of, 129.

dicotyledonons, 44 .

didynamous, two long and two short; applied to stamens, 37 .

Diffusion, 119.

Digitalis, 224.

digitate, 78 .

digynous, with two styles.

Dill, 190.

dimerous, applied to flowers with parts in twos.

Dimorphism of flax, 152.

dicecious, with staminate and pistillate Howers on different plants, 39 .

Dionæa, 185.

Dioscorea, 280.

Dioscoreaceæ, 279.

- Dipsaceæ, 1!8. 
Ilipterix, 170.

Jisk, a eellular ring- or cup-like thickening of the receptaele, either free, or adherent to the calyx tube or viary 34.

ilissected, cut into fine divisions.

Dissepiments, 92

distichous, in two rows.

clistractile, applied to anthers wheu the anther-lobes are widely separated from each other by an extension of the commective.

jock, 2:33.

bodder, $21 s$.

dodectudrous, with twelve sta. ninens.

torsal, 91.

Douglats Fir, 256.

Drosera, 185.

Drupace:e, 174.

Drupe. 95.

Dry-rot, 805 .

Drying jlants, $30 \mathrm{~s}$.

Duckweed Fanily, 260.

bucts, lotted and pitted vessels.

Inuramen (sce Heart-wood).

Durin, 287.

Duteli Rush, 302.

1)yer's Wuad, 142.

Earth-nut, 169.

kbony (West Indian), 171.

ebructeate, S.j.

Helinops, 206.

elcuborated s:I], 120.

ílaters, elastic spiral fibres asso-

eiated with the spores of certain

Cryptogans.

lisder, 194.

lilements in plants, 16.

Shephast's Fvot, 280.

elliptical, 75.

Whin Fanily, 243.

ditolea. 260.

enarginate, 79 .

limbryo, 10.

Limorgo-sac, the large sac of the nueleus of the orule in which the enıbryo originates, 24.

Embryo-vesicle; the rudimentary cell from which the embryo develops, formed within the embryo-sac; ealled also the zerminal vesicle.

L. ichanter's Nightshade, I7S.
Endocarp, the inner layer of tho periearp.

endogenous, 116.

Enclosperm, albumen formed inside the embryo-sae.

Endostome, the micropylar opening through the inner eoat of an orule.

ennea-, nine in eomposition.

enneandrnus, il.

ensiform, sword-shaped.

entire, 7 , so.

Envelopes, of the flower, 21.

Enicalyx, 154, 175.

Evicarp. the outer layer of the lericarp.

Eprielermis, 120.

epignnous, inserted upon the ovary; aplulied to pretals and stanens, 33.

Epilobe, 17\%.

Ejimedimm, 133.

epipetalous, 35.

epiphyllons. 51.

epijliytal, 275.

cqually pinnaie, pinnate without an ofld, terminal leatlet.

Equisetaeex, 301.

Equisetum, 301.

cruitant, applied to conduplicate leaves fulded one over the other (leaves of Iris), 277.

Eignt, 305.

Eriva, $20 \mathrm{~s}$.

Ericacere, 208.

Erioplurum, 281.

Erodium, 159.

Eryngo, ISS, 189.

Eschscholtzia, 138.

Enonymus, 163.

Euphorbia, 237.

Enphurbiacer, 235.

Euphrasia, 224 . .

Evening Primrose, 178.

Everlastings, 206.

cxalbuminc us, 45, 102.

exogenous, 115.

Exogonium, 218.

Exostome, the nieropylar opening through the outer coat of an ovule.

exserted, projeeting beyond.

exstipulate, 81.

lixtine, the outer coat of a polleugrain.

extrorse, applied to anthers de- 
lisciing on the sicle from the pistil.

Eyebright, 224, 225.

Fagus, 247 : decmihed. 320.

folcate, curved like a seytlie.

fresciulate, 81 .

Fenthru Ginss, 2S4.

Fennel, iss, 1S?.

Ferr Family. 294.'

fiertilizution of ornle. 23.

Pilro-rasculetr system, 112.

filmons, 60.

Eicus, 243

- ful, in romposition, divided to abont the middle.

Fig. 100, 213

Figwort, Ranumeulus, 131.

Filament, S.

Filices, 293.

giliform, lluearl-like.

fimbricete, fringed by fine divisions

of the lannina.

Fir. 251.

fistular, hollow, 2 SG.

Flig, $27 \%$.

Flax, 151 .

Flax Fanily, 151.

Hlax, New Yealanel, 269.

Floret, the flower of a Composite, or of a Griss.

Flower, structure of, 5 .

Flower-hecul. 35, S3.

Flowering Rnsli, 265.

Flowerless minnts, 292.

foliaccous, leat-like.

Foramen. (See Micropyle).

Forget-me-not, 219.

Foxerlove $22 t$.

Foxtail grass, 284.

Fraximus, 212.

free, ncither coherent nor adlierent.

free central placentation, 93.

French Beius, 171.

French-berries, 165.

Frogluit, 265.

Frond, the leaf of a fern, or leaflike expansion of a Cryptogam.

Fruit, 10, 94, 101.

Fuelisia, 1-8.

Fueus, $30 \mathrm{~s}$.

Fumariace, 139.

Fumitory Eamily, 139.

Fungi, 303.
Funicle, 164.

Furze, 16s, 169.

fusiform, spindle-shaped.

Galbulus, 254.

guleate, helmet-shaped.

Gallic acicl, $24 \%$.

Gimopetalie, 57, 193.

gamophyllous, 50 .

gumosepulous, 29.

Garancine, 197.

Garlic, 268.

germincete, in pairs.

Gentian Family, 216.

Gentianacer, 216 .

fenus, 1ㄴ.4.

Gelaniacex, 159 .

Geranimn Faurily, 152.

Germination, 44.

gibbous, witli a sliort, obtuse spur.

Ginsener, 191.

melornits, 5, S1.

Glatiolus, 27 .

Glands. cells, or hairs containing or secueting resinnis ol cily mattel ; or the lubes of the involucre of Spmige. 2:3S; or of a disk; glumels of pollinia, 273.

Glisswort, 232 .

Glaucous, bluish-green.

Glanx, 210.

Glumes, the sealy bracts of Grasses inn Selges, 52.

Gluniferes $5 S, 2 S 1$.

Glyeyrlizi, $1 \% 1$.

Gonidice, eclls (aipable of ieveioy ing new plants, libentel liy the vegetative system of leaflesg Cryplogaus, 306.

Good-King-Henry, 2:2.

Guoseberry, 96, 1 s3.

Goosefort Fannily, 230.

Goosegrass, 197.

Gossypium, 156.

Gourd Family, 1 so.

Graft, 177.

Gram, 172.

Gramince, $2 \mathrm{S3}$.

Grass Family, 283.

Grass-rluth, 241.

Ground-nits, 172.

Guelcler Rose, 194.

Gum Arabie, 172.

Gutta Percha, 23s.

Gymnospcrms, plants with naked 
seeds; i.e. not anclosed in an ovary.

gymn ospermous, 253.

gynandrous, applied to stamens adhering to the pistil, 50 .

gyrobasic, 220.

Gynocium, the pistil, or carpels of a flower colleetively.

Gynophore, a stalk supporting the ivary above the rest of the flower.

-gynous, in composition, applying to the pistil.

Hrematoxylon, 171.

Hair Moss, 302.

heiry, 5 .

Hart's-tongue, 295.

hastute, 76 .

Ilazel Family, 244.

licurt-wood (or duramen), the matured central portion of the wood of Exogens.

Heath Family, 20 s.

Hedera, 190 ; described, 318.

Helianthus, 205.

Heliotrope, 220.

Hellehore, 131.

Hemlock, 190.

Hemp, 240.

Henbane, 221.

Henna, 180.

Hepatica, 131.

hepta-, seven in composition.

heptandrous, 61.

Heracleuı, 186 ; described, 317.

lerbaceous, not woody; dying down in winter, 3.

Herbarium, 308.

hirmaphrodite, with stamens and pistil in the same flower.

heteronamous, 203.

hex-, hexu-, six in composition.

hexandrous, 61.

Hilum, the point of attachment of a seed or ovule, 43.

hirsute, with rather long, stifi hairs.

hispid, with short harsh hairs.

Holly Family, 161.

homogamous, 203.

Honeysuckle Family, 193.

Hop, 241.

Hordeum, 284, 288.

IIornbeam, 247.

Horsa Chestnut, 162.
Horsetail Family, 301.

Houscleek, 183.

Hoya, 216.

Hrmulus, 241.

Hyacinth, 269.

Hybrid, a cross between twi species.

Hydrangea, 185.

Hydrocharidex, 265.

Hydrocharis Fantily, 265.

Hydrocotyle, $18 S$.

Hymenium, the surfice bearing spores or sporidia in leafless Cryptogams; usually restricted to Fungi.

Hyoscyamus, 221.

Hypericinex, 148.

Hypericum Fanily, I4S.

hypocruteriform, salver-shaped ; applied to gamojetalons carollas with a long tube, and flat, spreading limb.

rypogynous, inserted under the ovaly; applied to stamens and petals, 9

I celand Moss, 806 .

icosandrous, witl twenty stamesis; applied to flowers in which they are inserted upon the calyx.

Ilex, 164.

imbricate, overlapping, 86 .

imparipirnate, pinnate with an odd leaflet.

imperfect, with stamens only, or with pistil only.

Incompletre, 57, 230.

incomplete, when one or more of the whorls (calyx, carolla, stamens, or pistil) is absent from a flower.

incumbent, 143 .

indefinitr, 85, 96, 102, 113.

indehiscent, 97 .

inceterminate, applied to an inflorescence which is indefinite or centripetal

Indian Corn, 284, 290.

Indian Cress, 160.

India-rubber, 243.

Indigo, 171.

Indigofera, 1 t1.

Individuals, 124.

Indusium, 295.

inferior (ovary), adherent througl. 
out, $0:$ nearly so, to the calyx ; (calyx) free from the ovary; (relation of parts of a Hower to the axis) farthest from the axis; (radicle) directed towards the basc of the fruit.

Inflorescence, 83.

infundibuliform, funnel-shaped.

innate, applied to anthers when

the filament appears to terminate at their base.

inorganic elements, 17.

Insertion, point of attachment.

iztercellulur spaces, 121.

Internode, 5.

interpetiolar, between the petioles of opposite Ieaves; applied to stipules, \&c.

Intine, the inner coat of a pollengrain.

introrse, applied to anthers dehiscing on the side towards tlre pistil.

Involucre, a whorl of bracts, 34,83 .

involute, with the inargins rolled inwards.

Ipccaettanlia, 197.

Iridex, $2 \pi 0$.

Iris Family, 276.

irregular, 29.

Irritability, 172.

Isatis, 142.

Ivory, vegetable, 262, 263.

Ivy, 190 ; described, 318.

Jalap, 218.

Jerusalem Artichokc, 205.

Jcssamine, 215.

Joint, the point where two parts arc united.

Jonquil, 279.

Judas-tree, 170.

Jujubes, 166.

Juncaceæ, 269.

Juniper, 253, 255, 257.

Jute, 153.

Kalmia, 209.

Keel, a median projecting ridgc; keel of piapilionaceous corolla, $16 \mathrm{~S}$.

Kelp, 308.

I abiate, 225.

Labiate Family, 225.

Laburnum, 171.
Lace-bark, 235.

laciniate, irregularly cnt.

Lady's slipper, 275

Lagetta, 235.

Lamb's-lettuce, 198.

Lamina, 86.

Lamium, 225.

lanate, with wool-like, rather long and felted hairs.

lanceolate, 75 .

Larch, 255.

Larkspur, 131.

Lattice-leaf, 261.

Laurel, 177.

Lavender, 227.

Leafiet, 77.

Leaves, 4, 69 ; forms of, 75 .

Lecanora, 306.

Legumes, 170.

Leguminosæ, 166 .

Leguminous Family, 166.

Leinna, 260.

Lemnaceæ, 260.

Lentils, 171.

lepidote, scaly.

Liber, 114, 11 .

Lichen Family, 306.

Lichenes, $306^{\circ}$.

ligneous, 41.

Ligule, 286.

Ligulifloræ, 202, 206.

Lilac, 214.

Liliaccæ, 267.

Lily Family, 267.

Limb, 35 ; of calyx or corolla, 86 .

Lime Family, 156.

Limnanth, 217.

Linaceæ, 151.

Linaria, 222.

linear, 75.

Linnæa, 195.

Linseed, 152.

Lobelia, 267

Lobes, 86.

loculicidal, applied to the deliscence of a capsule by the dorsal sutures of its component carpels.

Locust-trce, 170.

Locusta, the spikelet of grasses.

Lodicule, 53.

Logwood, 171.

Iolium, 284.

Lonicera, 194.

Loosestrife, 178.

Loranthaceæ. 191. 
Intus, 136, 166.

Lousewort, 224 .

Isunaria, 142.

Lallizla, 270.

Lycoparsicum, 222.

Lycopolincer, 293.

Lycopodium, 299.

lyrate, pinnatilid, witl the terminal lole largest.

Hythraecse, 17S.

Lythrmin Fannily, 17S.

Maccaroni, $2 S S$.

Mace, 164 .

Mardder, 197.

Madder Fimily, 195.

Maize, 2S!, 200.

Mallow Fannily, 153.

Malt, $2 S S$.

Malvacere, 153.

Mandioer'a, $23 \mathrm{~s}$.

Mangold Wirrzel, 232.

Manihot, :3S.

Manna. 214.

Maple Family, 161.

marcescont, persisting when withered and dry; applied to the corolla.

Margin, So.

Marigold, 203; Frenel and African, 207.

Marjoran, 227.

Mat Grass, $2 S 4$.

Maté, 16:

Medick, 170 .

Medullary rays, 117.

Meliek, 283.

Melon, 181.

Menyanthes, 217.

Mercurialis, 236.

Nerenry, 2:36.

Mericarp, 197.

Mezereoll, 235.

Mieropyle, 23, 43 .

Mid-rib, 73 .

Mignonctte Family, 143.

Mildew of Whent, 305 .

Milkwort Family, 160.

Mimnsa, 172.

Mimosere, 172.

Mimulus, 225.

Mint, 227 .

Minute structure of plants, 104.

Mistletoe Family, 191.

Molasses, $2: 0$.

non-, mono-, one in composition, nonandrous, $6 \mathrm{t}$

Monkey-flower, 225.

Monkshoodi. 131.

Monoclilamydex, 57, 230.

nonochlanydeous, with ealy: $x$ only, 39.

Monocotyleulons, 56-5S, $25 \mathrm{~S}$.

monocotyledonous, 55 .

monccious, with staminate and pistillate flowers on tlie same plant, 39

monogynous, with one style or one carjel.

monopetalones, with one petal: often enuployed instearl of gamnpetar lous. i.e. with culnerent pelals.

Moollwort, 290.

Morus, 241.

Moscatel, 194.

Moss Family, 302.

Moulus, 20:3.

Mousetail, 1.11.

mucronate, with a minute, ha:d loint (mucro) terminating the mid-rit.

Mulberly, 99, 241.

Mullein, 224.

mulli-, in composition, many.

Musei, 302.

Mushnomin Family, 303.

Musk. 225.

Mycelixm, 304.

Nyosote, 219.

Myosotis, 219.

My'ospermull, 171.

Naiad Family, 261.

Nálalere, 201.

Narcissus, $27 \mathrm{~s}$.

Nilldus, 254.

Nasturtium, 160.

Natural Orilers, 123, 126, 129.

Nectary, appliesl, vaguely, to glands, lobes of the riisli, modified petals, spurs, or other finnl appenclages, espeeially if sceretiug flniel, 272.

Nelumbium, 136.

Nerium, 216.

Nettle, $3 \mathrm{~S}$.

Nettle Family, 240.

Nicotiana, 221.

Nigella, 131.

Nightihiade, 221.

Nitrogen of plants, 18.

Node, 5 . 
Nuclens, (of a cell) a minute body, serving alparently as tle centre of activity of the contents : (of an ovule) the central mass, 23.

N'xt, 94.

nutant, nodding.

Nutmeg, 164.

Nutritive organs, 19.

Nymphxaceæ, 134.

Oak, 246.

Oak-woorl, vessels of, 106.

Oat, 2S4, $23 \%$.

obcordate, 76 .

oblanceolete, 70 .

obliupe leaves, 157.

oblong, T5.

obovate, 76.

obtuse, 70 .

Ochreu, a sheathing, membranous stipulate.

oct-, or" octo-, eiglut in composition. octcundrous, 6 il.

Ginantlic, 190.

Ginotlera Family, 17:.

Oil, 111.

Oil, Palm, 263.

Olea, 214.

Oleacete, 212.

Oleaniler, 216.

Olive, 214.

Olive Family. 212

Onagraces, 177.

Oniun, 2 (is.

Operculitm, a lid; applied to the lirl of the sporange of nosses, 302.

Oplioglossum, 297.

Opiun Poply, 138.

opposite, 70 .

() riche, 2:31, 282.

Orange, 96.

orbicular, 75 .

Orchid Family, 271.

Orchidacex, 271.

Orclis, 49, 271 ; described, 321.

Ordeal beans, 172 .

Ordeal poison of Madagascar, 216.

Organic elcments, 16.

Drgans of nutrition, 20.

Organs of reproduction, 20 .

Orontium, 259.

orthotropous, appilied to ovules when the organic base of $a$ straight nucleus (where it is united to the coat or conts of the ovule) coineides with the lilum, ancl the micropyle is at the further extremity.

Oryza, 2S4, 259.

Usier, 251.

Osmunda, 296. .

oval, 75 .

Ovary, 9.

orate, 75.

ovoid. egg-shaped; applier to solids.

Ovule, 9, .91.

Oxalis, 160.

Oxygen gas, 17.

Pale, 53; Palss of the enmmon leceptacle, 203.

Palm Fanily, 262.

pulmatifid, 7 .

promutipartite, 7 .

Panax, 191.

Penicle, S5.

meniculate, S5.

Pansy, 146.

Papalvelacere, 137.

Paper Mulberly, 243.

Papilionaces, $106,108$.

papilionaceous, 168.

Papplis, 204.

Pal'yl'us, 253.

Paraguay Tea, 165.

f'aranhyses, inieroscopic filaments. associated with the thecas of eertain Cryptogams.

Parcisites, plants whict prey upon the juices of other plants.

Parenchyma, tissue of slort cells. purietal, 93.

Paris, 26S.

Parsley, 159.

Parsuip, 189.

Pca, 29, 166 ; deseribed, 316.

pecincite, with comb-lilie tectlı or lobes.

peciate, digitate with the latcral leaflets springing from the branches of a short fork of the petiole.

pedutiful, pedatipartits, applied to a simple leaf divided ou tle pedate plan.

pedicel, the stalk of each single fiower of a two- or mure flowercd inflorescence.

Pedicularis, 224.

Peduncle, 6. 
Pelargonium, 160.

Peloria, the regular form of a flower normally irregular. of Linaria, 224.

peltate, 80 .

Penny-royal, 227.

penta-, tive in composition.

pentamerons, applied to flowers with the parts in tives.

pentandrous, 61.

Pentstemon, 225.

Peppermint, 227.

perennial, lasting several years, or indefinitely.

perfoliate, 79.

Perianth, the envelope of a flower, collectively. In practice, applied to the envelopes of the flower of Monocotyledons and to the envelope of molrochlamydeous flowers, 50.

Periearp, 94.

Perigynium, 283.

perigynous, inserted around the ovary; apllied to petals and stamens, 29.

Perisperm, albumen originating outside the embryo-sac. Often applied to albumen irrespective of its place of origin.

Peristome, 303.

Peritheeium, a nearly closed, or quite closed cavity containing theca in Cryptogams. Applied to the elosed apothecia of some Lichens.

Periwinklc Family, 215.

persistent, 24.

personate, bilabiate, with the lips closed.

Peruvian Bark, 197.

Petcls, 7

petaloid, petal-like, or corollalike.

Petaloideæ, 5S, 264.

Petiole, 5.

l'etiolule, the petiole of a leaflet.

Peziza æruginosa, 248.

Phanerogamic, bearing flowers; uscd in contradistinction to Cryptogamic.

Phormium, 269.

Phyllades, \$2.

Phyllotaxis, the arrangement of leaves upon the stem.

Physalis, 221.
Piaçaba fibre, 263

Pileus, 3c4.

pilose, with ratler long, soft hairs. Pimpernel, 210.

Pine Family, 251.

Pink Family, 146.

pinnate, 78 .

pinnatifid, 77 .

pinnati-partite, 77.

Pinnules, 294.

Pinus, 251.

Pistil, 10, S7

Pisum, 166.

litch, 257.

Pith, 116.

Placenta, the part of the ova:y upon which the ovules are inserted.

Plaeentation, 93.

Plantaginex, 229.

Plantago, 230.

Plantain Family, 229.

Plantain, Water, 264.

plieate, folded.

Plumbagine:e, 229.

plumose, plume-like.

Plumule, 43, 55 .

pluri-, several in composition.

Pollen, S, 22.

I'ollinium, 273.

poly-, many in composition, 7 .

polyadelphous, 149.

polyandrous, 8, 61.

polycotyledonous, 255.

Polygalacese, 160.

polygamous, with male, female, and hermaplirodite flowers un the same, or on distinct plants, 214.

Polygonacex, 232.

Polygonum Family, 232.

polugynous, "with numerous carpels, or styles.

Polypetalæ, 57.

polypetalous, 7 .

polyphyllous, applied to perianths consisting of tiee leaves.

Polypody: 295.

polysepalous, 7.

Polytrichuin, 302.

Pomaceæ, 174.

Pondweed, 261.

Poplar, 250.

Poppy Family, 137.

Populits, 250.

posterior, same as superior when 
applied to the relation of the parts of a flower to the axis.

''otamogeton, 26].

Potato, 221.

Potato, Sweet, 218.

prumorse, applied to roots terminating abruptly.

Pricliles, sharply-pointed projections originating from the bark, as in Bramble and Rose.

Primine, the outer coat of an ovule.

Primrose, 37 ; describer, 31 s.

Prinrose Family, 209.

Primulacere, 209.

Frivet, 214.

rocumbent, applied to stems which spread upon the gromnt. proliferous, froducing leaf-buds in the place of flower-buds or seeds.

Prosenehyma, a tissue of long tavering cells.

Prothullium, 298.

P'cudo-bulbs, 275.

Ptcris, 296.

Pterocarlus, 170.

pubesccnt, lowny with very shert, soft hairs.

Pufr-ball, 305.

Pnlque, 279.

Punplin, 1 s1.

murctute, dotted.

Putcuncn, the endocarp of stonefruits.

quadri-, four in romposition.

Quaternary compounds, 17.

Quercus, 247.

Quinine, 197.

quinine-, five in composition.

quinquefoliolate, 79.

Raceme, 83; racemosc, 85.

Ruchis, the axis of an inflorescence, or of a compound eaf or fromel.

ralical, 5.

Radicle, 43, 55 .

Ragwort, described, 31 .

licimentum, the chaffy scales on the rachis of fcrns.

Rampion, 208.

lianunculacer, 129.

Rammiculus Family, 129

liaphe, that portion of the vascu.. lar cord connecting the chaliza of an ovule with the placentr, which is adberent to the side of the ovule.

Raphides, 112.

Rattans, 263.

Rattle, 224.

Ray, 34.

Recepiacle, 7.

Receptacle, common, 34, 84.

regular, 7.

Reindeer Moss, 307.

reniform, 75 .

lieplum, the persistent sutural frame remaining after the fal! of the valves in some Crucifer:e, Leguminosæ, \&c. 142.

Reproductive organs, 20.

Resedacere, 133.

Resin, 257.

Respiration, vegetable, 18.

rcsupinatc, applied to flowers when reversed, or upside down. retusc, applied to a very obtuse extremity notched in the midule. revolute, with the margins loller outwards.

Rhammareæ, 165.

Rheum, 233.

Rhinanthus, 224.

Rhizome, 67.

Rhododendron, 209.

rhomboidul, lozenge-shaper.

Rhubarb, 233; cells and vessels ol, 104.

Ribesiacex, 183.

Ribwort Plantain, 230.

Rice, 284, 290.

Rice-priper, 191.

Ricinus, 239.

ringent, bilabiate and gaping.

Roceclla, 306.

Rock-cist, 145.

Root, structure of, $2,11,65$.

Rosacere, 17:3

Rose Fanily, 173.

Rose, fruit of, 100.

Rosem, 174.

Rosemary, 22\%.

Rosewood, 170.

Rostellum, 50, 273.

rotate, applied to a gamopetalous regular corolla, with a short tube and spreading limb.

rotundate, 75 .

Rubiace: 195. 
rugne, wrinkled.

Rumex, 28:3.

muminated, 164.

muscincte, pinnatifid, with the segr-

ments directed downwards.

Rumner, a rooting prostrate sledder lumne:.

Ruscus, 26 S.

Rush Fanily, 269.

Rush, rloweriug, 265.

Rushlights, 2T1.

Rye, 2s4, 2S5.

Ryc Giass, 2St.

Saccharum, 290.

Satllower, 206 .

Satfron, $27 \%$.

Sagre, 2:27.

suggittete, 76 .

Sayon, $2(i 3$.

St. Joln's-wrrts, 148.

Salicacere, 249 .

Salicolntil, 2:32.

Sallow, 250 .

Salsify, 206

Salsola, 232.

Saltwort, \pm 32 .

Sumaru, a winged fruit, or coccus, $16 \%$

Samolus, 210.

Samplitic, 1SS, 189.

sand Cillex, 283

Sanders-wood, 171.

Sindwort, 148 .

Sanguisurlse:e, 174.

Sanicle, 189.

Sap, 11 .

Say green, 165.

Srip-wood (or alburnum), the younger outer portion of the wood of Exogens. It takes a principal part ill the upward conveyance of sap, and is usually of palsr colour than the heartwood.

Sapindac :æ, 161.

Saponaria, 147.

Sapotacex, 238

Sappan-wood, 171.

Savory, 227.

Saxifragacere, 184.

Saxifrage Family, 184.

Scabious, 199.

scabrous, rough to the touch.

Srale-leàes, 71.

Scammony, $21 \mathrm{~s}$.
Scape, S3.

sccirious, dry and rather stimy membinanous.

Sca.let Rummers, 172.

Scheclules, 59.

Si:irpus, 283.

scolopendrium, 295.

scorpioid, enrled to one side.

Suorzonera, 206.

Scotel Fir, 251.

Seropliulaia Family, 222.

Scrophulariacex, 222.

Sea Kale. 143.

Sea Maram, 2S:3.

Senweed Fanily, 307.

Sieuile, 284 .

secund, turned to one side.

Sesundine, the inner evat of an ovile.

Secium, 152.

Secal, 10, 102; of Dicotyledous, 43 ; of 11 mocolyluchons, 54.

Sedge Family, ¿S1.

Segment, 5.

Sempervivum, 1S.

senchiera, 1+1, 189.

Senceio, 207.

Sepuls, $i$.

septenl-, seren in composition.

septicidul, nipulied to the dehiscence of a capsule by the septa or malrgins of its component carpels.

Scptum, a partition or dissepiinent.

sericcous, conered with silly appressed liails.

serrate, 80.

scssile, 5.

Scta, a bristle, 303.

sitaccous, bristle-like.

se $x_{-}$, six in composition.

Slieep-sorrel, 23:3.

Shepherd's-purse (Capsella), 142

Shield Fer'n, 29.4.

Silene, 147.

Silicula, 142.

Siliqua, 142.

simple leaves, 74.

sinurte, wavy.

Sinus, the space between lobes or seginents.

Siphonia, 23S.

smooth, plain; without protukerances.

Binut. 305. 
Snapdragon, 225.

Snowdrop, 279 .

Soapwort, 147.

Solanaceæ, 220.

Solanum Family, 220.

solitary, 102.

Sorghum, 287.

Sorrel, 160.

Sorne, 294.

Spadicifloræ, 58, 258.

Spadix, 48.

Spanish Juice, 171.

Spathe, 47.

spathulate, 76.

Species, 124.

Speedwell, 224.

spicate, 85.

Spignel, 189, 190.

Spike, 83.

Spikelet, 52.

Spikenard, 195.

Spinach, 232.

Spindle-tree, 163.

Spines, sharply-pointed projections originating from the wood, ind regarded as abortive branches, leaves, or peduncles, as in Common Hawthorn, 69.

Sporanges, 295.

Spores, 293, 295.

sporidiferous, 305.

sporiferous, 305.

Sprice, 256.

Spu , a conical projection, usually from the base or side of a sepal (calyx) or petal (corolla).

Spurge Daphne, 234.

Śpurge Fanily, 235.

Squirting Cucumber, 182.

Stag's-horn Moss. 300.

Stamens, 8; opjosite to petals, 133.

Staninode, a rudimentary stamen.

Standard, 167.

Stapelia, 216.

Starch, 110.

Stellatæ, 195.

Stellate Tribe, 195.

Stem, 3, 11, 67.

Stephanotus, 216.

Stigma, 9.

Stipa, 284.

Stipules, 80, 81.

Stock, 5, 41, 68 .

Stolon, a short rooting branch.

Stomates, 121.

Stone-fruits, 95.
Stone Pine, 257.

Stonecrop, 182.

Stork's.bill, 159.

Strawberries, 98.

striate, marked with fine lines.

Style, 9 .

subulate, 75 .

succulent, fleshy.

Sugar, 111.

Sugar-cane, 290.

Sugar Maple, 162.

sulcate, furrowed.

Sundew, 185.

Sunflower, 205.

superior, applied to the ovary when wholly free from the calyxtube, 10 ; applied to the radicle of the embryo, when straight, and directed towards the apex of the fruit; applied to the calyx when the limb of the calyx appears to be inserted upon the ovary, owing to the adhesion of the ovary to the tube of the calyx, 32.

Suppression, 27, 95.

Surface, 80.

sutural, 94.

Sutures, 91.

Sycamole, 162.

symmetrical, applied to flowers with the number of parts in each whorl equal or multiples. syncarpous, 92.

syngenesious, 36.

Tamarind, $] 71$.

Tamus, 279.

Tanghinia, 216.

Tannin, 247.

Tap-root, 65.

Tapa-clotlı, 243.

Tapioca, 238.

Tar, 257.

Taraxacum, 200.

Taxus, 253.

Tea, 150.

Teak, 228.

Teak, African, 239.

Teasel Family, 198.

Tectona. 228.

Teeth, 86, 97.

Tendrils, 69, 81 .

terete, when the transverse section is circular.

terminal, 67. 
Ternary compounds, 17 .

ternate, 'T9.

Ternströmiaceæ, 150 .

T'esta, 10.

Testudinaria, 280.

tetra-, four in composition.

tetradynamous, four long and two short; applied to stamens, 28 , 141.

tetramerous, applied to flowers with the parts in fours.

tctrandous, 61 .

Thalamifloræ, 58, 129.

'Thalamus, the floral receptacle.

Theca, a cell containing the spores of Cryptogans

Theobroma, 158.

Thistle, 200, 20 i, 205.

Thorn-apple, 221.

Thrift, 229.

Thyme, 227.

Thymelacere, 233،

Tiliaccæ, 156.

Tissues, various, for exanimation, 107.

Toadflax, 222 .

Tobacco, 221.

Tomato, 222.

tomentose, with short, dense, more or less felted, cottony hairs.

Tonquin Bean, 170.

Toothcress, 142.

Torns, the floral receptacle.

Touch-wood, 305.

Towel-gourd, 181 .

Tragacanth, 171.

Transpiration, 15,

Treacle, 290.

Tree-ferns, 299.

tri-, three in composition.

triandrous, 61.

tricoccus, applicel to a syncarpous fruit consisting of three cocci.

trifid, 79 .

trifoliolate, 79.

trigonous, tliree-romered in cross section, with the angles obtuse.

trimerous, applied to flowers with the parts in threes.

Trimorphism of Ly hrum, 180.

tripartite, 73 .

triquetrous, three-comered in cross section, with the angles acute.

Triticnu, 2s3, 284, 287.

Tropæolun. 160.

Truflle, 305. truncate, terminating abruptly.

Tube, 86.

Tuber, 68 .

tuberous roots, 66 .

Tubulifloræ, 202, 204.

Tulip, 267.

tunicate bulb, 268.

Turpentine, 257.

Ulex, 168, 169 .

Ulmacer, 243.

Umbel, 83.

Umbellate Fanily, 185.

Umbelliferæ, 185.

uncinate, hooked.

unequally pinnate, pinnate with an odd leaflet.

uni-, one in composition.

unilocular, one-celled; applied to anthers and ovaries.

unisexual, with stamens only, or with pistil only.

unsymmetrical, apulied to flowers with the parts of each whorl unequal in number or not multiples, 36.

Upas, 243.

urceolate, urn-shaped.

Urtica, 239.

Urticaceæ, 239.

Vaccinium, 20s, 209.

Valerian Family, 197.

Valerianeæ, 197.

Vallisneria, 266 .

Valonia, 247.

valvate, 86

$V$ alves of fruit, 97.

Vanilla, 276.

Varieties, 127.

Vascular bundles, 118.

Vascular plants, 303.

Veins, 73.

Venation, 73.

ventral, 91 .

ventricose, inflated.

Verbascum, 222, 224.

Verbcna, 228.

Verbenacex, 228.

Vermicelli, 288.

Vernal Grass, 284, 286.

Vernation, 73.

Veronica, 224.

verrucose, warted.

versatile, applied to anthers when 
attached by the back to the slender tip of the filament. verticillate, whorled, with three or more parts inserted in the same plane; applied to foliar organs, 70.

Vervein, 22s.

Vervein Fanily, 228.

Vessels, 106.

Vexillum, 169.

Victoria regia, 136.

Vinca, 215.

Violaceæ, 145.

Violet Family, 145.

Viscum, 191.

Vitis, 184.

Vittoe, 188 .

Wallflower, 28, 140 ; described, 315 .

Water, source of, in plants, 17.

Water Plantain, 264.

Waterlily Family, 134.

Water-weed, 266.

Weeping Willow, 251.

Weld, 144.

Wellingtonia, 257.
Weymouth Pine, 256.

Wheat, $52,283,284,287$; described, 322 .

Whorl, 7.

Whortleberry, 208.

Willow, 39.

Willow Family, 249.

Willow-herb, 177.

Wings (of papilionaceous corolla), $1 \mathrm{c} 8$.

Winter Cherry, 221.

Woad, 143.

Wood, structure of, 114, 115

Wood Sorrel, 160.

Woudruff, 195.

Wych Elm, 243.

Yam Family, 279.

Yew, 253, 254, 257.

Yucea, 269.

Zea, 2S4, 290.

Zinnia, 207.

Zizyphus, 165.

Zoospores, 307.

Zostera, 261.

THE END.

R. CLAY, SONS, AND TAYLOR, PRINTERS, LONDON. 






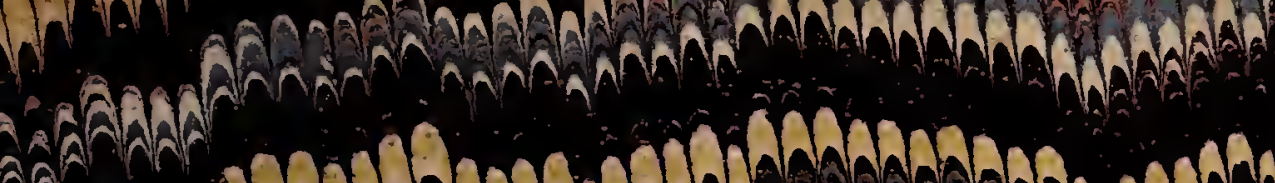
a

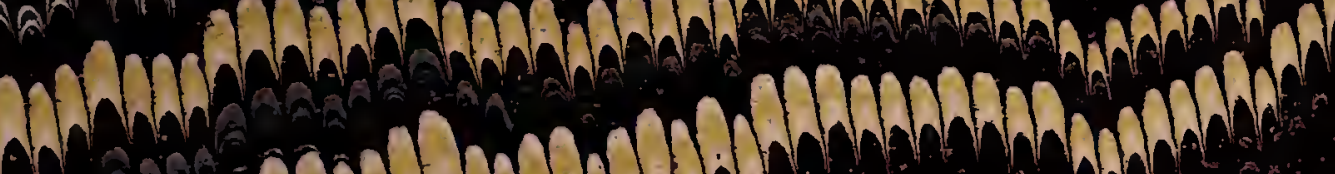

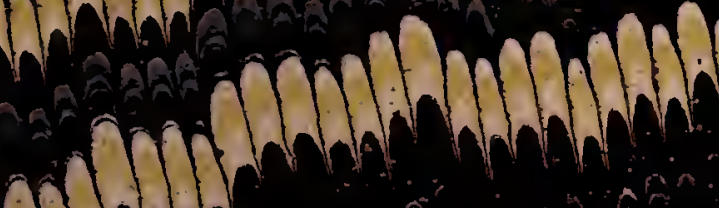

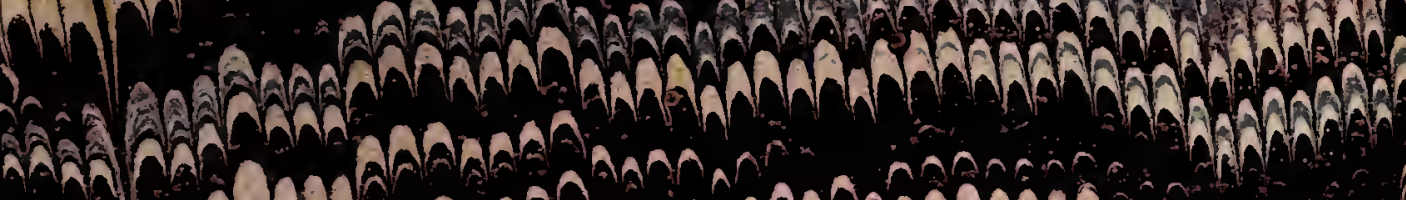

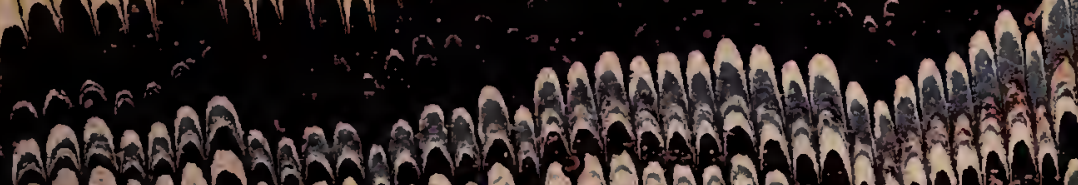

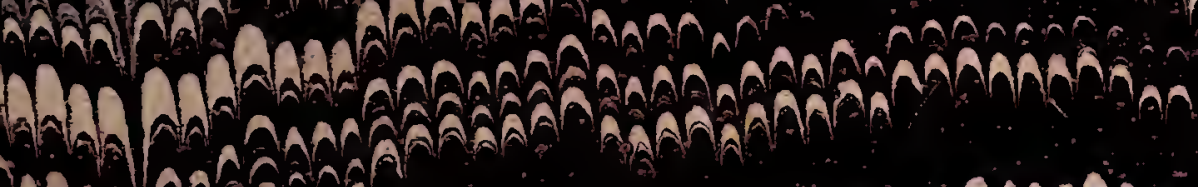

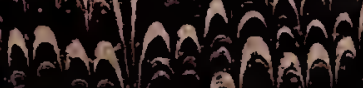

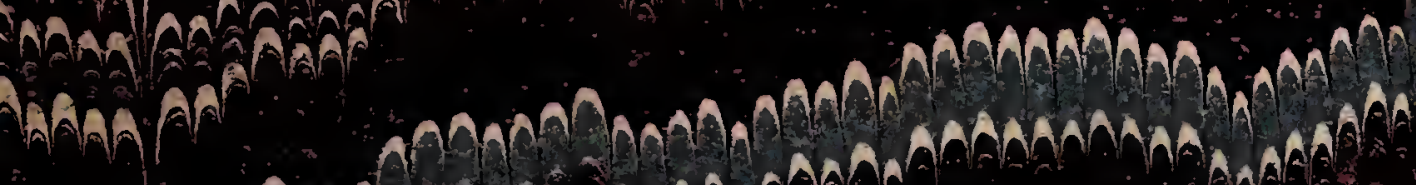
Tha ma AaAA

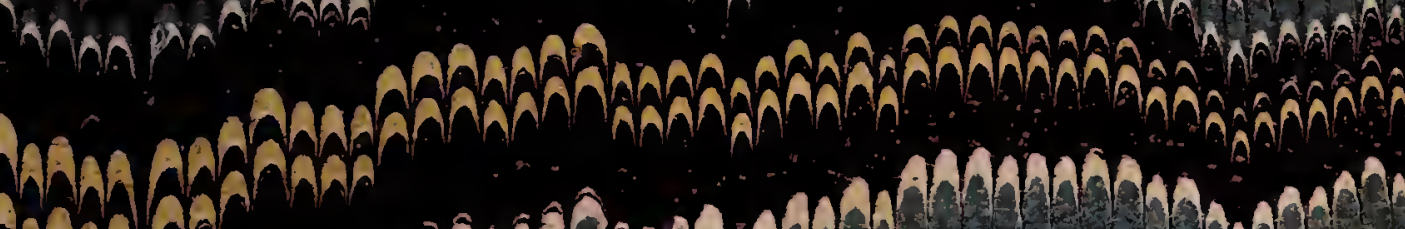

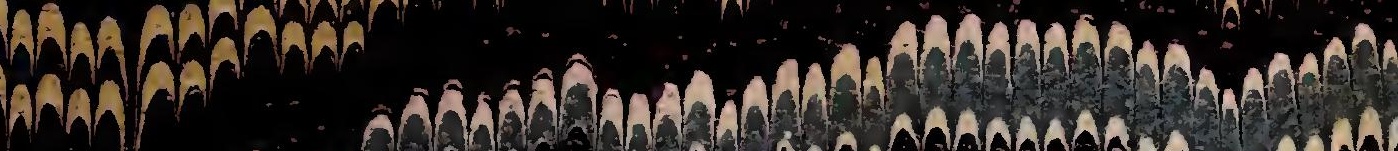
AnคิA

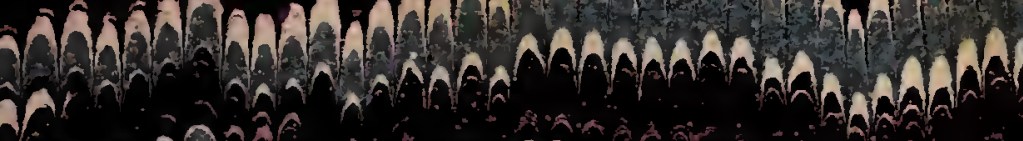

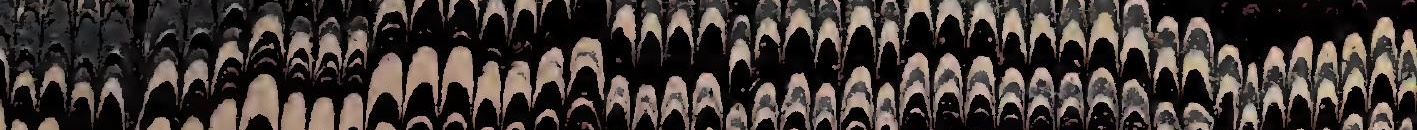
Tha

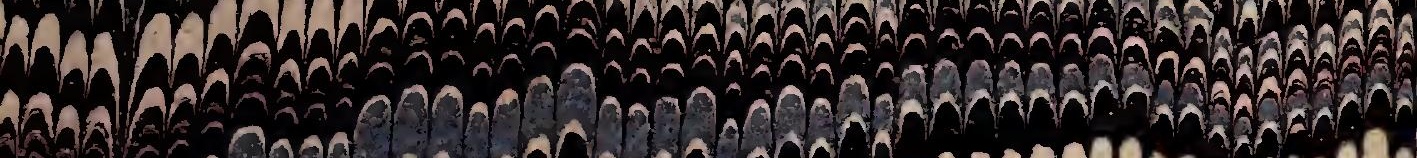

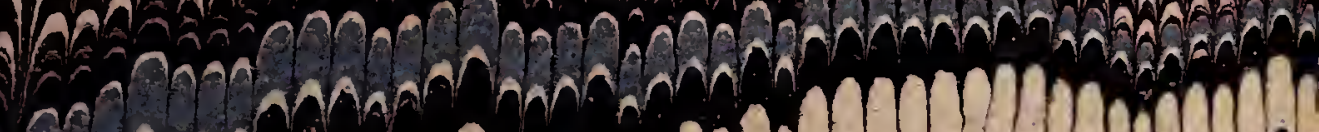

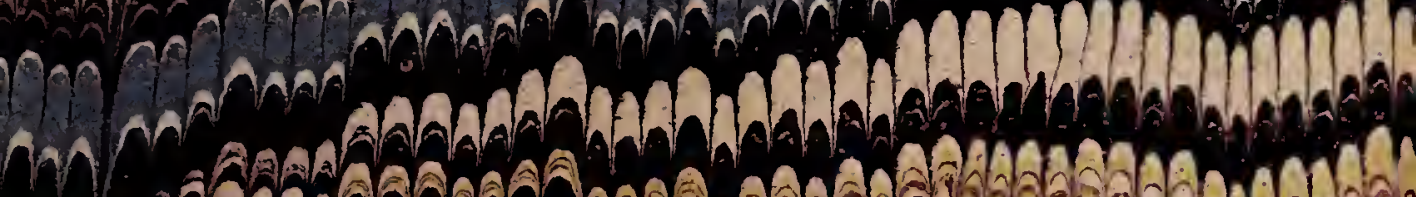

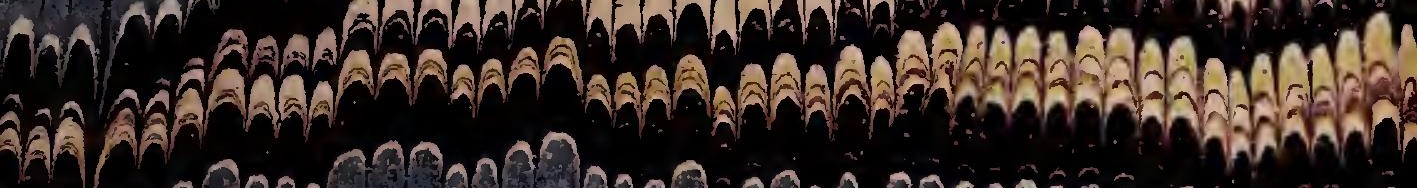

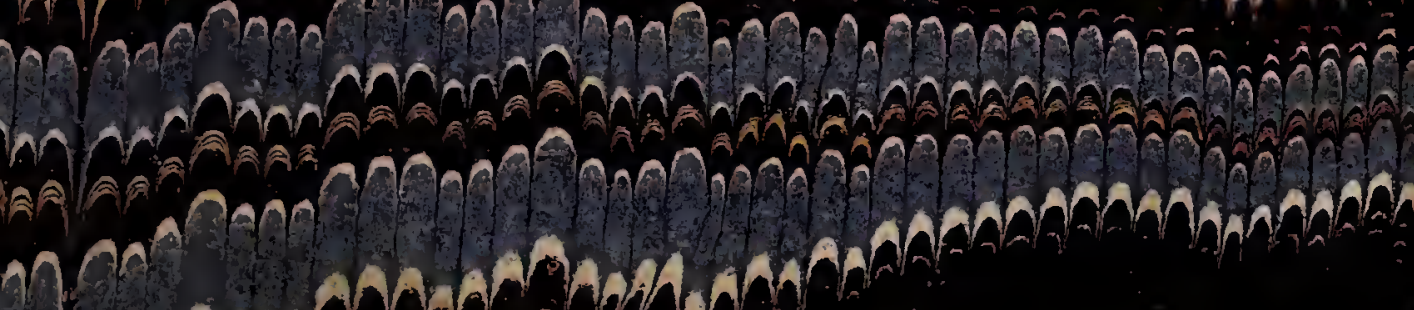




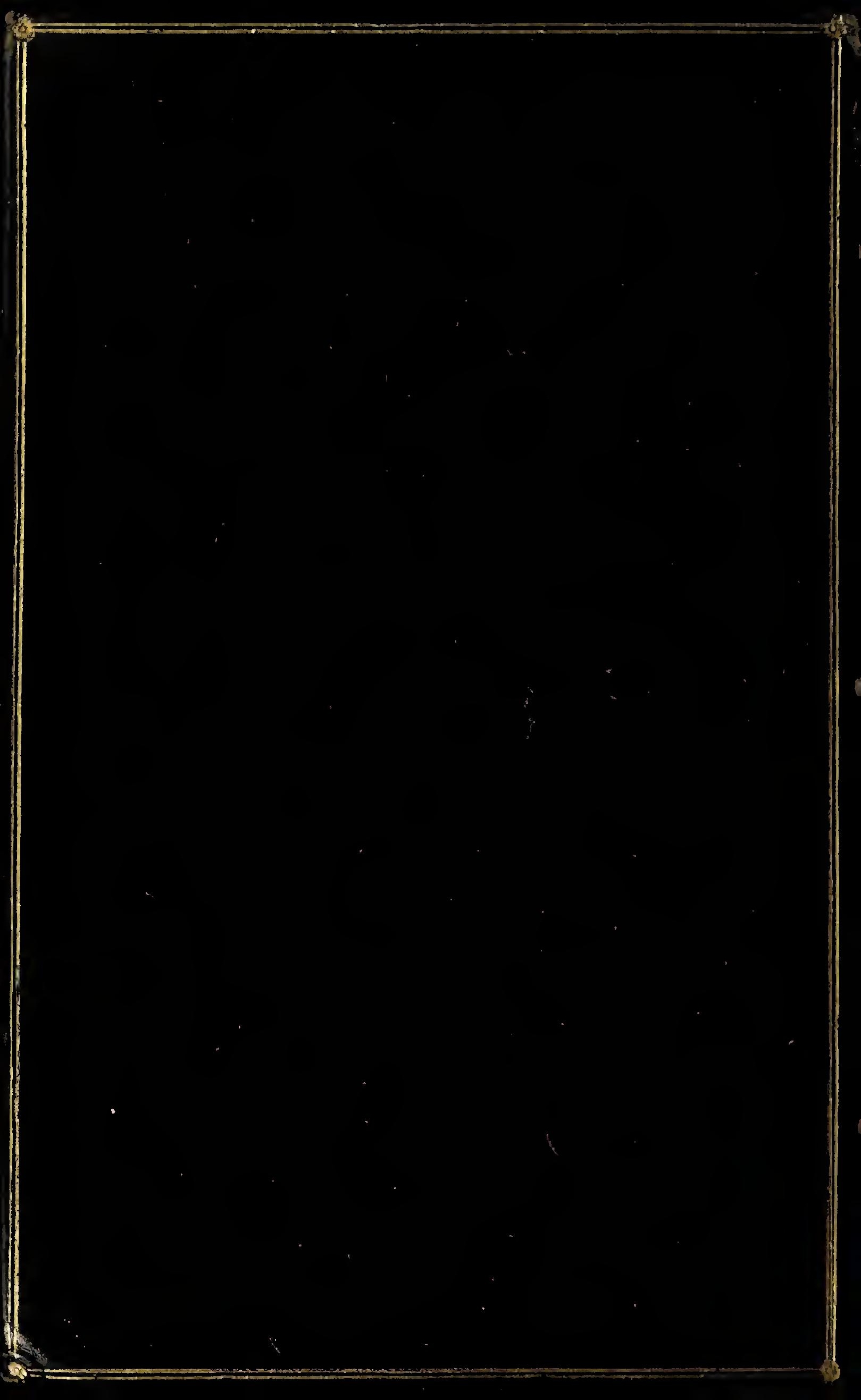

